\title{
O IMPACTO DAS FACHADAS VERDES NOS MICROCLIMAS URBANOS
}

\author{
Dissertação apresentada à Faculdade de Arquitetura e Urbanismo da \\ Universidade de São Paulo para obtenção do título de mestre em Arquitetura e \\ Urbanismo
}

Área de Concentração: Tecnologia da Arquitetura Linha de pesquisa: Conforto Ambiental, Eficiência Energética e Ergonomia Orientador: Prof. Dr. Denise Helena Silva Duarte 


\title{
O IMPACTO DAS FACHADAS VERDES NOS MICROCLIMAS URBANOS
}

\begin{abstract}
Dissertação apresentada à Faculdade de Arquitetura e Urbanismo da Universidade de São Paulo para obtenção do título de mestre em Arquitetura e Urbanismo
\end{abstract}

Área de Concentração: Tecnologia da Arquitetura Linha de pesquisa: Conforto Ambiental, Eficiência Energética e Ergonomia Orientador: Prof. Dr. Denise Helena Silva Duarte

EXEMPLAR REVISADO E ALTERADO EM RELAÇÃO À VERSÃO ORIGINAL, SOB RESPONSABILIDADE DO AUTOR E ANUÊNCIA DO ORIENTADOR.

O original se encontra disponível na sede do programa. São Paulo, 17 de abril de 2018. 


\section{AUTORIZO A REPRODUÇÃO E DIVULGAÇÃO TOTAL OU PARCIAL DESTE TRABALHO, POR QUALQUER MEIO CONVENCIONAL OU ELETRÔNICO, PARA FINS DE ESTUDO E PESQUISA, DESDE QUE CITADA A FONTE.}

e-mail: priscilastark@yahoo.com.br

Catalogação na Publicação

Serviço Técnico de Biblioteca

Faculdade de Arquitetura e Urbanismo da Universidade de São Paulo

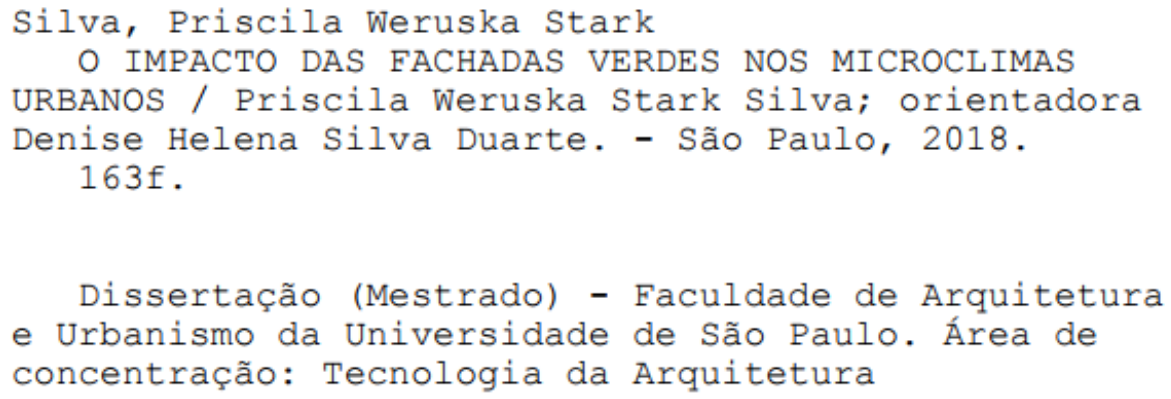

1. Paredes Verdes. 2. Vegetação Urbana. 3. Microclimas Urbanos. 4. Simulação Computacional. 5. Políticas Públicas. I. Duarte, Denise Helena Silva, orient. II. Título. 


\section{DEDICATÓRIA}

Aos meus filhos, que são a razão para a busca de me tornar melhor a cada dia.

Ao meu companheiro de vida, por me incentivare apoiar na realização dos meus sonhos.

À minha avó lrmgard, meu exemplo de vida, por acreditar e me encorajar em todos os momentos. 
Ao Conselho Nacional de Desenvolvimento Científico e Tecnológico (CNPq) pela concessão de bolsa de mestrado para o desenvolvimento desta pesquisa

À minha orientadora, Profa. Dra. Denise Helena Silva Duarte, pelo acompanhamento incondicional em todas as etapas deste trabalho, pela confiança em meu potencial e pelas contribuições à minha formação como pesquisadora, pela amizade e carinho

Aos professores Dr. Fábio Mariz Gonçalves e Dr. Humberto Ribeiro da Rocha pelas importantes contribuições oferecidas em minha banca de qualificação

À Dra. Paula Shinzato, por todo tempo a mim dedicado, pelos conhecimentos compartilhados, pelos ensinamentos sobre o modelo ENVI-met, pelos conselhos, pelas sugestões, pelas conversas e pela amizade

Aos professores do Laboratório de Conforto Ambiental e Eficiência Energética LABAUT: Dra. Joana Carla Gonçalves, Dr. Leonardo Marques Monteiro, Dra. Alessandra Prata Shimomura e Dra. Ranny Loureiro Xavier Nascimento Michalski, pelas trocas de conhecimento, experiências e pelo incentivo

Aos colegas e pesquisadores do Laboratório de Conforto Ambiental e Eficiência Energética - LABAUT, por toda generosidade, ajuda e carinho: Aparecida A. Bou Ghosn, Luciana Schwandner Ferreira, Carolina Gusson 
A todos os funcionários da Faculdade de Arquitetura e Urbanismo da Universidade de São Paulo, por sua dedicação e atenção, em especial ao funcionário Ranieri Higa, pelo suporte indispensável em todas as etapas do processo de medição micrometeorológica

A meu colega e bom amigo Henrique Sala Benites, por sua generosidade, por compartilhar comigo as aflições e conquistas que compõem este processo

Aos meus sogros Milton e Magaly por todo apoio emocional aos meus filhos nos momentos de ausência para desenvolvimento desta pesquisa

Aos meus pais e irmãos pelo incentivo e celebração em cada etapa vencida Aos meus filhos Letícia e Bruno que embora sem compreender exatamente os motivos da minha ausência prolongada são a razão para todo meu empenho Ao meu esposo Thiago, pela compreensão, pela paciência, por estar ao meu lado em todos os momentos, incentivando, acreditando, aceitando e principalmente pelo seu imenso amor. 
O uso de vegetação nas superfícies urbanas tem despertado a atenção de pesquisadores, empreendedores e da população em geral, pelos benefícios que pode proporcionar às construções, geralmente como coberturas e fachadas verdes. Comparadas às coberturas, as fachadas verdes podem representar maiores superfícies em edifícios altos de áreas densamente ocupadas, incrementando massa foliar e trocas térmicas úmidas no entorno imediato, contribuindo para o balanço de energia nas áreas urbanas. Neste trabalho realizaram-se levantamentos da inclusão das paredes verdes nas políticas públicas, das diferentes tecnologias de paredes verdes, além de estudos de desempenho microclimático de paredes verdes. Há uma série de trabalhos quantificando o efeito das superfícies verdes no desempenho térmico dos edifícios, sabendo-se pouco sobre seus efeitos microclimáticos urbanos. Nesse contexto, o objetivo deste trabalho é quantificar o impacto das fachadas verdes no microclima urbano no nível do pedestre, considerando as variáveis temperatura e umidade do ar, temperatura de superfície e temperatura média radiante. Em função das restrições e recursos do modelo ENVI-met, adotado neste estudo, a pesquisa incluiu, inicialmente, um método dedutivo, exploratório, através de medições de densidade foliar da vegetação do tipo escaladora e monitoramento de alguns dados microclimáticos em uma fachada verde. $\mathrm{Na}$ etapa seguinte o método é indutivo, realizando-se testes de sensibilidade do modelo em cenário hipotético, variando-se índice de área foliar (IAF $0,5 \mathrm{~m}^{2} / \mathrm{m}^{2}, 1 \mathrm{~m}^{2} / \mathrm{m}^{2}$ e $2 \mathrm{~m}^{2} / \mathrm{m}^{2}$ ) e umidade do solo (50\% e $60 \%$ ). As conclusões confirmam o efeito microclimático bastante localizado da parede verde do tipo escaladora e um comportamento distinto nos períodos diurno e noturno, como acontece em outras formas de inserção do verde em áreas urbanas. À noite, na ausência da evapotranspiração, o resfriamento é mais influenciado pela troca convectiva. Durante o dia percebe-se o efeito da evapotranspiração no ligeiro aumento da umidade do ar em $1,0 \mathrm{~g} / \mathrm{kg}$, à temperatura do ar de $26^{\circ} \mathrm{C}$, e na diminuição da temperatura do ar, em ambos os casos quando comparadas ao cenário sem vegetação, em $0,17^{\circ} \mathrm{C}, 0,36^{\circ} \mathrm{C}$ e $0,68^{\circ} \mathrm{C}$ com os incrementos sucessivos do IAF, para umidade do solo $50 \%$, às $14 \mathrm{~h}$, principalmente a sotavento. Os efeitos da vegetação na temperatura radiante média são bastante 
localizados, tornando sua influência praticamente imperceptível no microclima exterior sob o efeito da radiação solar, apesar dos incrementos do IAF. O incremento na umidade do solo, de $50 \%$ para $60 \%$, resulta em aumento da evapotranspiração provocando redução máxima de cerca de $0,36^{\circ} \mathrm{C}$ na temperatura do ar a $1,5 \mathrm{~m}$ do solo, para o mesmo IAF. O sombreamento provocado pela vegetação resulta em variação insignificante na TRM mesmo com o aumento na umidade relativa do solo, para o mesmo IAF. Os testes de sensibilidade mostram que o modelo é adequado para realização de estudos mais aprofundados, justificando o investimento em pesquisas futuras visando à calibração entre dados microclimáticos medidos e simulados para paredes verdes em clima tropical e subtropical e à simulação microclimática de áreas urbanas com o uso dessa tecnologia.

Palavras-chave: Paredes Verdes; Vegetação Urbana; Microclimas urbanos; Simulação Computacional; Políticas Públicas. 
The use of greenery on urban surfaces, normally green roofs or green facades has attracted the attention of researchers, entrepreneurs and the population in general for its benefits to buildings. Compared to green roofs, green facades may represent higher surfaces in tall buildings of densely occupied areas, increasing foliage mass and latent heat exchanges for the immediate environment, contributing to energy balance in urban areas. With a focus on green walls, this work carried out investigations about their inclusion in public policies, green walls' technologies and microclimate performance studies. Despite the existence of numerous papers quantifying the effect of green surfaces on the thermal performance of buildings, there is limited available knowledge regarding their effects on urban microclimate. In this context, the aim of this work is to quantify the impact of green façades on urban microclimate at pedestrian level, considering the variables air temperature, air humidity, surface temperature, and mean radiant temperature. Based on the restrictions and resources of the ENVImet model, which was adopted in this study, the research initially included a deductive exploratory method through measurements of leaf area density of climbing plants and monitoring of some microclimatic data at a green façade. In the next stage, the method was inductive, with sensitivity tests of the model in a hypothetical scenario, varying the leaf area index (LAI $0.5 \mathrm{~m}^{2} / \mathrm{m}^{2}, 1 \mathrm{~m}^{2} / \mathrm{m}^{2}$ and $2 \mathrm{~m}^{2} / \mathrm{m}^{2}$ ) and soil humidity (50\% and $60 \%$ ). The results confirm the localized microclimatic effects of the climbing green wall and a distinct behaviour between daytime and night time, equivalent to those caused by other forms of greenery in urban areas. At night, with the lack of evapotranspiration, cooling is more influenced by convective exchange. The effect of evapotranspiration is clearly perceived during the day due to a) the slight increase in air humidity by $1.0 \mathrm{~g} / \mathrm{kg}$ at a temperature of $26^{\circ} \mathrm{C}$, and $\mathrm{b}$ ) the decrease of air temperature, when compared to the scenario without vegetation, of $0.17{ }^{\circ} \mathrm{C}, 0.36{ }^{\circ} \mathrm{C}$ and $0.68{ }^{\circ} \mathrm{C}$ (for LAI $=0,5 \mathrm{~m}^{2} / \mathrm{m}^{2}, 1,00 \mathrm{~m}^{2} / \mathrm{m}^{2}$ and $2,0 \mathrm{~m}^{2} / \mathrm{m}^{2}$ ), for a $50 \%$ soil humidity, mainly in the leeward direction. The effects of greenery on mean radiant temperature, despite the LAl increase, are quite localized, making its influence practically imperceptible on the outdoor microclimate under the effect of solar radiation. The increase of soil humidity from $50 \%$ to $60 \%$ results in increased evapotranspiration 
leading to a maximum reduction around $0.36^{\circ} \mathrm{C}$ on air temperature, at $1.5 \mathrm{~m}$ from ground level, for the same LAI. Vegetation shading results in insignificant variation in mean radiant temperature. Sensitivity tests show that the model is suitable for further studies, justifying an investment in future research aiming at calibration between measured and simulated microclimate data for green walls in tropical and subtropical climates and the microclimatic simulation of urban areas with green walls' technology.

Keywords: Green Walls; Urban Greenery; Urban Microclimates; Computer Simulation; Public Policies. 
Figura 1- Porcentagem de área verde por habitante e em relação à área da subprefeitura na cidade de São Paulo, 2011. Fonte: dados disponíveis em www.nossasaopaulo.org.br, acesso junho de 2015, sobre base do Mapa Digital da Cidade (CESAD-FAU/USP e L. Ferreira, mapa elaborado originalmente para DUARTE, 2015).

Figura 2 - Parede em pedra com vegetação. Disponível em:

http://articles.extension.org/pages/13038/landscaping:-design-and-plant-selection.

Acesso agosto 2017.

Figura 3 - Gabião com vegetação. Disponível em:

<http://www.isa.utl.pt/ceabn/projecto/1/78/projecto-de-estabiliza-ccedil-atilde-o-de-umtalude-na-a21-n-oacute-da-malveira-com-t-eacute-cnicas-de-engenharia-natural>. Acesso agosto 2017.

Figura 4 - Fachada verde tradicional. Disponível em <http://www.clarkeassociates.cc> acesso em outubro 2016.

Figura 5 - Sistema de suporte com cabeamento. Disponível em

$<$ http://www.decorcable.com>

Figura 6 - Sistema de suporte modular. Disponível em <http://greenscreen.com/\#> Acesso em outubro 2016.

Figura 7 - Sistema de paredes vivas em feltro desenvolvido por Patrick Blanc. Fonte:

https://www.verticalgardenpatrickblanc.com/.

Figura 8 - Sistemas extensivos (fachadas verdes), segundo Osmond e Sharifi (2017)20

Figura 9 - Sistemas intensivos (paredes vivas), segundo Osmond e Sharifi (2017)... 20

Figura 10 - Classificação das paredes verdes de acordo com suas características

construtivas. Fonte: Manso et al. (2015).

Figura 11 - Sistema de suporte geotêxtil. Disponível em

<http://www. verticalgardenpatrickblanc.com> acesso em outubro 2016.

Figura 12 - Sistema de suporte modular. Disponível em <http://www.gsky.com> acesso em outubro 2016.

Figura 13 - Balanço de energia no período diurno de um dia de verão (Bonan, 2008).30 Figura 14 - Generalização dos processos-chave na formação de microclimas urbanos durante o verão para paisagens urbanas convencionais (disponibilidade de água limitada) ( $A$ e $C$ ) e paisagens urbanas com maior capacidade de absorção hídrica ( $B$ e D), nos períodos diurno e noturno. Fonte: COUTTS et al. (2013). 34

Figura 15 - Diferenças relativas na temperatura média diurna do ar no cânion arborizado ( $a$ e c c) e cânion sem vegetação ( $b$ e d) em janeiro de 2012, sob as direções do vento norte ( $a$ e b) e sul ( $c$ e d). O sol está ao norte. Fonte: Coutts et al., 2016...... 35 Figura 16: Desenho do experimento com sensores para medição da temperatura do ar próxima às paredes verdes. FONTE: WONG, N.H. Handbook on Green Walls in Singapore, Singapore: National Parks Board, 2009 p. 59. 38 Figura 17: Sensores para medição de temperatura do ar próxima às paredes verdes. FONTE: WONG, N.H. Handbook on Green Walls in Singapore, Singapore: National Parks Board, 2009 p. 59. 
Figura 18 - Camadas de vegetação com diferentes índices de área foliar, utilizadas no estudo de Susorova et al., 2013.

Figura 19: Variáveis consideradas no balanço de energia do modelo ENVI-met.

Disponível em < http://www.model.envi-met.com > Acesso em outubro de 2016......... 55

Figura 20: Layout básico modelo computacional ENVI-met.............................................. 56

Figura 21: Diferentes conceitos de organização da grade vertical (A) Equidistante (B1) Telescópica (C) Grade telescópica sem fator de extensão. Disponível em <http://www.model.envi-met.com > acesso em outubro de 2016.................................... 58

Figura 22 - "Basic settings" utilizados no domínio do modelo simulado........................... 61 Figura 23 - Representação gráfica da vegetação arbórea no modelo, no módulo Albero do ENVI-met. Disponível em <http://www.model.envi-met.com > acesso em outubro de 2016. 64

Figura 24 - Modelo típico de visualização de dados na ferramenta Leonardo.

Disponível em <http://www.model.envi-met.com/> acesso em outubro 2016. .68

Figura 25 - Vista e orientação solar da fachada estudada ................................................... 71

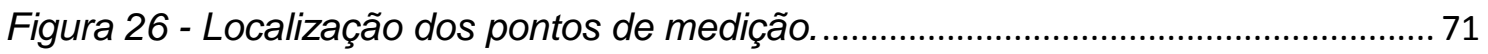

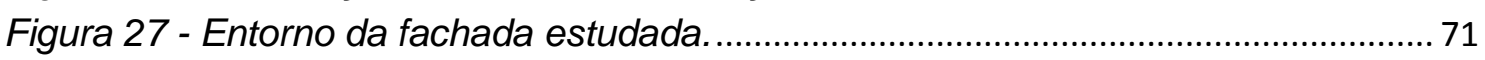

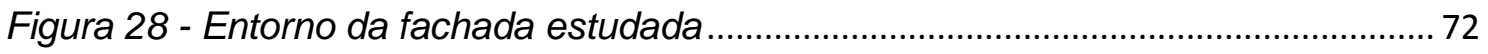

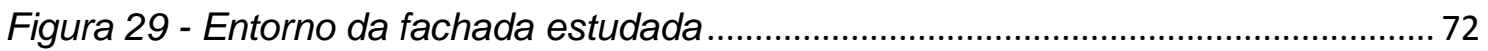

Figura 30 - Localização e posicionamento do ponto 1 de medição. ................................... 73

Figura 31 - Foto hemisférica demonstrando a visão de céu no Ponto 1......................... 73

Figura 32 - Localização e posicionamento do ponto 2 de medição. .................................... 74

Figura 33 - Visão de céu às 8h, 12h e 20h próxima à fachada estudada........................ 75

Figura 34 - Área de 50 x 50cm considerada na medição do DAF.................................... 75

Figura 35 - Temperatura do ar $\left({ }^{\circ} \mathrm{C}\right)$ medida dentro e fora da vegetação nos pontos $1 \mathrm{e}$ 2, e dados da Plataforma Micrometeorológica IAG USP e da estação automática de

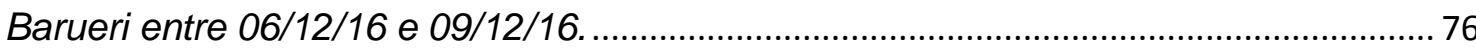

Figura 36 - Umidade específica do ar (g/kg) calculada segundo Bolton (1980). ............ 77 Figura 37 - Temperaturas do solo $\left({ }^{\circ} \mathrm{C}\right)$ medidas dentro (P3) e fora da vegetação (P4), entre 06/12/16 e 09/12/16 .......................................................................................... 78

Figura 38 - Temperatura do ar e temperatura de globo $\left({ }^{\circ} \mathrm{C}\right)$ registradas a $1 \mathrm{~m}$ da

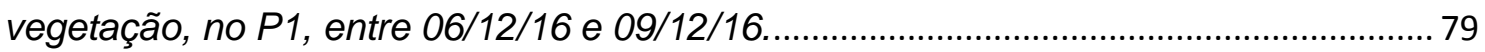
Figura 39 - Disposição da edificação e vegetação na modelagem construída no ENVImet, layers "Buildings" e "Soil and Surface"...................................................................... 80 Figura 40 - Visualização 3D do cenário paramétrico simulado, layer "Soil and Surface".

Figura 41 - Layers "Buildings" e "Vegetation" do modelo para os cenários

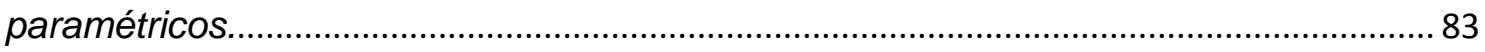

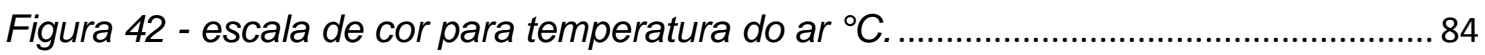

Figura 43 - escala de cor para diferença de temperatura do ar ${ }^{\circ} \mathrm{C}$....................................... 84

Figura 44 - escala de cor para temperatura de superfície ${ }^{\circ} \mathrm{C}$........................................... 84

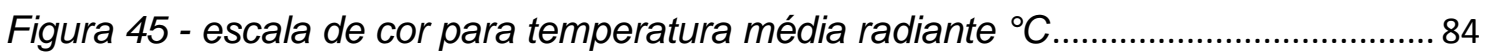

Figura 46 - escala de cor para umidade específica $\mathrm{g} / \mathrm{kg}$................................................ 84

Figura 47 - Temperatura do ar em ${ }^{\circ} \mathrm{C}$ para $I A F=0,5 \mathrm{~m}^{2} / \mathrm{m}^{2}, I A F=1,0 \mathrm{~m}^{2} / \mathrm{m}^{2} \mathrm{e}$ $I A F=2,0 \mathrm{~m}^{2} / \mathrm{m}^{2}$. 
Figura 48 - Exemplo de seleção da área para cálculo da temperatura média do ar realizado com a ferramenta Leonardo.

Figura 49 - Temperatura radiante média para $I A F=0,5 \mathrm{~m}^{2} / \mathrm{m}^{2}, I A F=1,0 \mathrm{~m}^{2} / \mathrm{m}^{2} \mathrm{e}$

$I A F=2,0 \mathrm{~m}^{2} / \mathrm{m}^{2}$ e umidade relativa do solo $50 \%$ às $14 \mathrm{~h}$.

Figura 50 - Temperatura radiante média para $I A F=0,5 \mathrm{~m}^{2} / \mathrm{m}^{2}, I A F=1,0 \mathrm{~m}^{2} / \mathrm{m}^{2} e$

$I A F=2,0 \mathrm{~m}^{2} / \mathrm{m}^{2}$ e umidade relativa do solo $60 \%$ às $14 \mathrm{~h}$.

Figura 51 - Diferença da TRM (K) para $I A F=0,5 \mathrm{~m}^{2} / \mathrm{m}^{2}, I A F=1,0 \mathrm{~m}^{2} / \mathrm{m}^{2}$ e $I A F=2,0 \mathrm{~m}^{2} / \mathrm{m}^{2}$ e

variação da umidade relativa do solo $50 \%$ e $60 \%$ às $14 \mathrm{~h}$. 88

Figura 52 - Temperatura do ar simulada com umidade relativa do solo de $50 \%$ nos cenários sem vegetação e com vegetação para $I A F=0,5 \mathrm{~m}^{2} / \mathrm{m}^{2}, I A F=1,0 \mathrm{~m}^{2} / \mathrm{m}^{2}$ e $I A F=2,0 \mathrm{~m}^{2} / \mathrm{m}^{2}$ às 6horas, $h=1,50 \mathrm{~m}$.

Figura 53 - Temperatura do ar simulada com umidade relativa do solo de $60 \%$ nos cenários sem vegetação e com vegetação para $I A F=0,5 \mathrm{~m}^{2} / 2, I A F=1,0 \mathrm{~m}^{2} / \mathrm{m}^{2}$ e $I A F=2,0 \mathrm{~m}^{2} / \mathrm{m}^{2}$ às 6horas, $h=1,50 \mathrm{~m}$.

Figura 54 - Diferença de temperatura do ar para $I A F=0,5 m^{2} / m^{2}, I A F=1,0 m^{2} / m^{2} e$ $I A F=2,0 \mathrm{~m}^{2} / \mathrm{m}^{2} \mathrm{com}$ relação ao cenário sem vegetação para umidade relativa do solo $50 \%$ às $6 h, h=1,50 \mathrm{~m}$.

Figura 55 - Temperatura do ar simulada com umidade relativa do solo de $50 \%$, cenários sem vegetação e com vegetação $I A F=0,5 \mathrm{~m}^{2} / 2, I A F=1,0 \mathrm{~m}^{2} / \mathrm{m}^{2}$ e $I A F=2,0 \mathrm{~m}^{2} / \mathrm{m}^{2}$ às 14horas, $h=1,50 \mathrm{~m}$.

Figura 56 - Temperatura do ar simulada com umidade relativa do solo de $60 \%$, cenários sem vegetação e com vegetação $I A F=0,5 \mathrm{~m}^{2} / \mathrm{m}^{2}, I A F=1,0 \mathrm{~m}^{2} / \mathrm{m}^{2} \mathrm{e}$ $I A F=2,0 \mathrm{~m}^{2} / \mathrm{m}^{2}$ às 14horas, $h=1,50 \mathrm{~m}$.

Figura 57 - Diferença de temperatura do ar para $I A F=0,5 m^{2} / m^{2}, I A F=1,0 m^{2} / m^{2} e$ $I A F=2,0 \mathrm{~m}^{2} / \mathrm{m}^{2} \mathrm{com}$ relação ao cenário sem vegetação para umidade relativa do solo $50 \%$ às $14 h, h=1,50 m$.

Figura 58 - Diferença de temperatura do ar para $I A F=0,5 m^{2} / m^{2}, I A F=1,0 m^{2} / m^{2} e$ $I A F=2,0 \mathrm{~m}^{2} / \mathrm{m}^{2}$ com relação ao cenário sem vegetação para umidade relativa do solo $60 \%$ às $14 h, h=1,50 m$.

Figura 59 - Temperatura do ar simulada com umidade relativa do solo de 50\% nos cenários sem vegetação e com vegetação para $I A F=0,5 \mathrm{~m}^{2} / \mathrm{m}^{2}, I A F=1,0 \mathrm{~m}^{2} / \mathrm{m}^{2} \mathrm{e}$ $I A F=2,0 \mathrm{~m}^{2} / \mathrm{m}^{2}$ às 22horas.

Figura 60 - Temperatura do ar simulada com umidade relativa do solo de $60 \%$ nos cenários sem vegetação e com vegetação para $I A F=0,5 m^{2} / 2, I A F=1,0 m^{2} / m^{2} e$ $I A F=2,0 \mathrm{~m}^{2} / \mathrm{m}^{2}$ às 22horas.

Figura 61 - Diferença de temperatura do ar para $I A F=0,5 \mathrm{~m}^{2} / \mathrm{m}^{2}, I A F=1,0 \mathrm{~m}^{2} / \mathrm{m}^{2}$ e $I A F=2,0 \mathrm{~m}^{2} / \mathrm{m}^{2}$ e variação da umidade relativa do solo $50 \%$ e $60 \%$ às $14 \mathrm{~h}, \mathrm{~h}=1,50 \mathrm{~m}$. 93 Figura 62 - Variação da temperatura do ar para $I A F I A F=0,5 \mathrm{~m}^{2} / \mathrm{m}^{2}, I A F=1,0 \mathrm{~m}^{2} / \mathrm{m}^{2} \mathrm{e}$ $I A F=2,0 \mathrm{~m}^{2} / \mathrm{m}^{2}$ e variação da umidade relativa do solo $50 \%$ e $60 \%$

Figura 63 - Temperatura de superfície simulada com umidade relativa do solo de $50 \%$ nos cenários sem vegetação e com vegetação para $I A F=0,5 \mathrm{~m}^{2} / \mathrm{m}^{2}, I A F=1,0 \mathrm{~m}^{2} / \mathrm{m}^{2} \mathrm{e}$ $I A F=2,0 \mathrm{~m}^{2} / \mathrm{m}^{2}$ às 14 horas.

Figura 64 - Temperatura de superfície simulada com umidade relativa do solo de $60 \%$ e $I A F=0,5 \mathrm{~m}^{2} / \mathrm{m}^{2}, I A F=1,0 \mathrm{~m}^{2} / \mathrm{m}^{2}$ e $I A F=2,0 \mathrm{~m}^{2} / \mathrm{m}^{2}$ às 14 horas.

Figura 65 - Umidade específica para $I A F=0,5 \mathrm{~m}^{2} / \mathrm{m}^{2}, I A F=1,0 \mathrm{~m}^{2} / \mathrm{m}^{2}$ e $I A F=2,0 \mathrm{~m}^{2} / \mathrm{m}^{2}$ e umidade relativa do solo $50 \%$ às $14 \mathrm{~h}$. 
Figura 66 - Umidade específica para $I A F=0,5 \mathrm{~m}^{2} / \mathrm{m}^{2}, I A F=1,0 \mathrm{~m}^{2} / \mathrm{m}^{2}$ e $I A F=2,0 \mathrm{~m}^{2} / \mathrm{m}^{2}$ e umidade relativa do solo $60 \%$ às $14 \mathrm{~h}$.

Figura 67 - Diferença de umidade específica para $I A F=0,5 \mathrm{~m}^{2} / \mathrm{m}^{2}, I A F=1,0 \mathrm{~m}^{2} / \mathrm{m}^{2}$ e $I A F=2,0 \mathrm{~m}^{2} / \mathrm{m}^{2}$ e variação da umidade relativa do solo $50 \%$ e $60 \%$ às $14 \mathrm{~h}$. 96

Figura 68 - Variação da umidade específica para $I A F=0,5 \mathrm{~m}^{2} / \mathrm{m}^{2}, I A F=1,0 \mathrm{~m}^{2} / \mathrm{m}^{2} e$ $I A F=2,0 \mathrm{~m}^{2} / \mathrm{m}^{2}$ e variação da umidade relativa do solo $50 \%$ e $60 \%$. 96

Figura 69: Integração vertical entre umidade e fluxos de onda-longa Disponível em <http://www.model.envi-met.com > acesso em outubro de 2016. 116

Figura 70 - Visão geral dos planos de paisagem de Berlim. Disponível em: $<$ <ttp://www.stadtentwicklung.berlin.de/umwelt/landschaftsplanung/bff/index_en.shtml> Acesso em janeiro de 2017.

Figura 71 - Planos de paisagem de Berlim, situações existente e pretendida.

Disponível em:

$<$ <ttp://www.stadtentwicklung.berlin.de/umwelt/landschaftsplanung/bff/index_en.shtml> Acesso em janeiro 2017.

Figura 72 - Terreno modelo utilizado para cálculo do BAF, situação inicial. Fonte:

www.stadtentwicklung.berlin.de. Acesso em janeiro 2017.

Figura 73 - Terreno modelo utilizado para cálculo do BAF, variação 1. Fonte:

www.stadtentwicklung.berlin.de. Acesso em janeiro 2017.

Figura 74 - Terreno modelo utilizado para cálculo do BAF, variação 2. Fonte:

www.stadtentwicklung.berlin.de. Acesso em janeiro 2017.

Figura 75 - Zonas de desenvolvimento urbano Seattle, Fonte: HIRST et al., 2008. ... 130

Figura 76 - Seattle DPD - Corporate Campus, Amazon Phase IV, plantas de

paisagismo. Disponível em

<http://www.seattle.gov/dpd/cs/groups/pan/@pan/documents/web_informational/s0481

47.pdf> Acesso em janeiro de 2017.

Figura 77 - Vista aérea de Western Harbor, Malmö. Fonte: Google Maps, acesso em janeiro 2017.

Figura 78 - Sistema para águas pluviais - Malmö. Fonte: Google Maps, acesso em janeiro 2017.

Figura 79 - Demarcações das áreas de Planejamento de Singapura. Disponível em <https://www.ura.gov.sg/uol/master-plan.aspx> Acesso em janeiro de 2017.

Figura 80: Quadro 3A Quota Ambiental de São Paulo. Disponível em:< http://gestaourbana.prefeitura.sp.gov.br/wp-content/uploads/2014/12/2014-12-23-

QUADRO-3A-minuta-PL-LPOUS-vfinal.pdf> acesso em dezembro 2016.

Figura 81: Quadro 3B Quota Ambiental. Disponível em:

$<$ <ttp://gestaourbana.prefeitura.sp.gov.br/wp-

content/uploads/2015/12/QUADRO_3B_18_12_15.pdfs acesso em dezembro 2016.

Figura 82 Quadro 3B Quota Ambiental. Disponível em:

$<$ http://gestaourbana.prefeitura.sp.gov.br/wp-

content/uploads/2015/12/QUADRO_3B_18_12_15.pdf> acesso em dezembro 2016. 
LISTA DE TABELAS

Tabela 1 - Classificação dos sistemas verticais para edificações. ..................................... 18

Tabela 2 - Classificação dos sistemas de paredes vivas................................................. 24

Tabela 3 - Comparação de vantagens e desvantagens dos sistemas de paredes

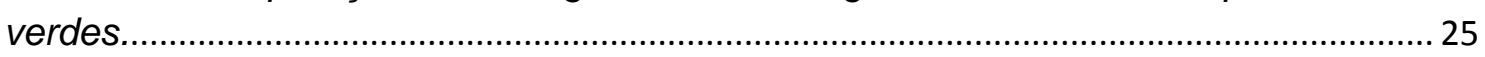

Tabela 4 - Especificações dos equipamentos utilizados em medição de campo .......... 69

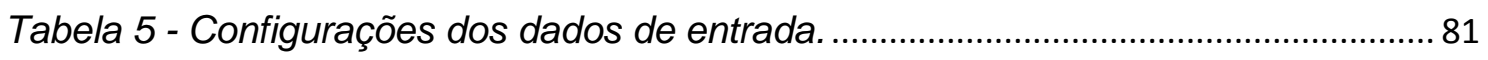

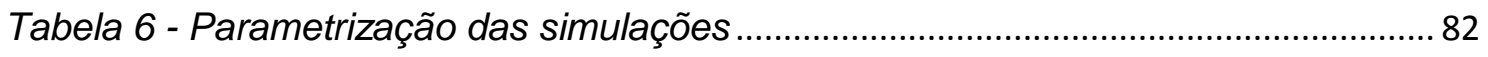

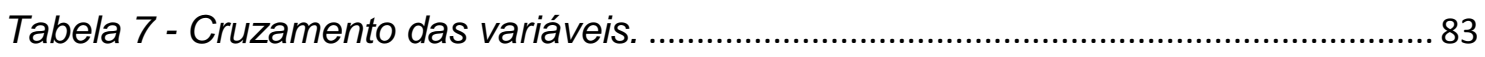

Tabela 8 - Tabelas de valores aplicáveis para definição das áreas verdes necessárias

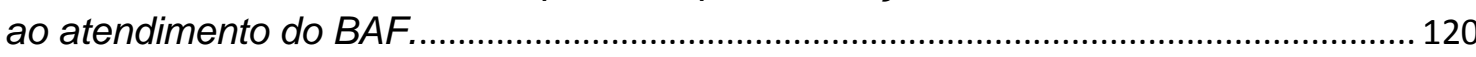

Tabela 9 - Coeficientes de ponderação para cada tipo de superfície............................... 122

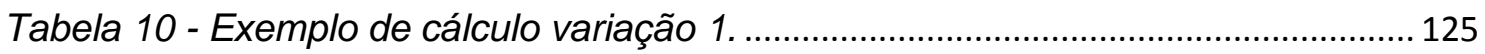

Tabela 11 - Exemplo de cálculo variação 2. ...................................................................... 127

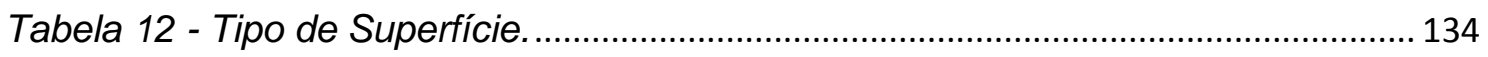




\section{SUMÁRIO}

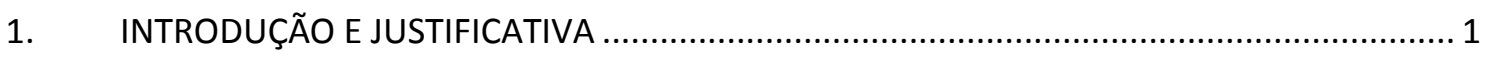

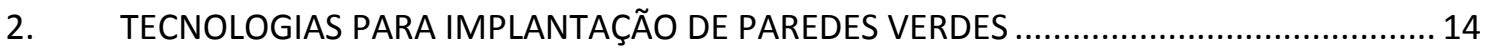

2.1 LIMITAÇÕES DOS SISTEMAS DE PAREDE VERDE E FALHAS DE OPERAÇÃO ..................27

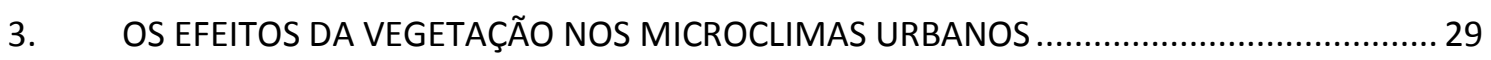

3.1 O BALANÇO DE ENERGIA EM ÁREAS URBANAS E O PAPEL DA VEGETAÇÃO ...................... 29

3.2 A INFLUÊNCIA DA VEGETAÇÃO NO MICROCLIMA E NO CONFORTO TÉRMICO URBANO 32

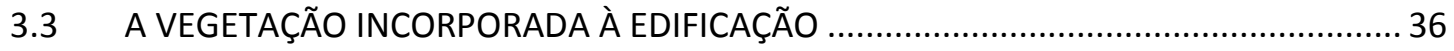

3.4 MODELOS PARA ESTUDO DO IMPACTO DA VEGETAÇÃO NO MICROCLIMA URBANO E

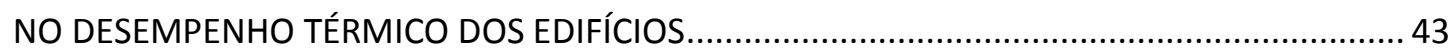

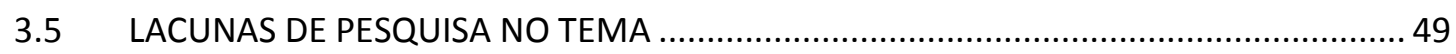

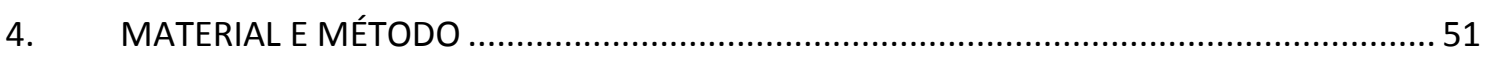

4.1 O MODELO NUMÉRICO DE SIMULAÇÃO ENVI-met E O PROCESSO DE MODELAGEM

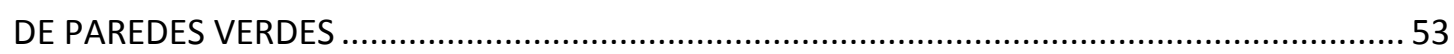

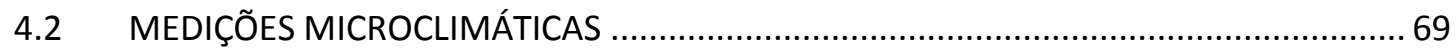

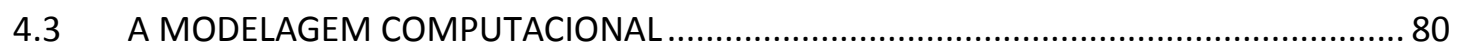

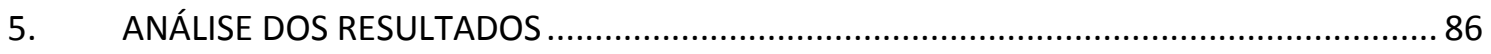

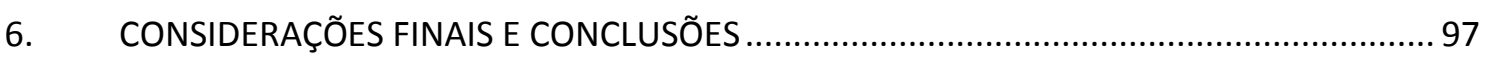

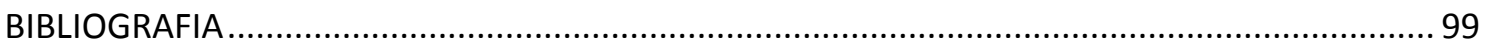

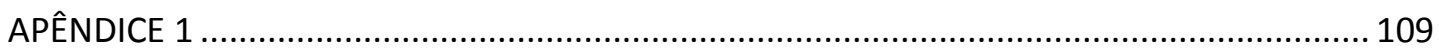

Módulo de Visão Panorâmica ENVI-met............................................................................ 109

Códigos internos do modelo ENVI-met V4.2: ................................................................. 112

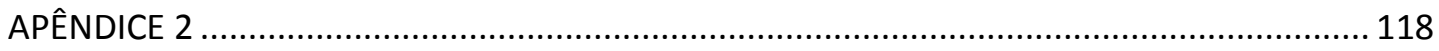

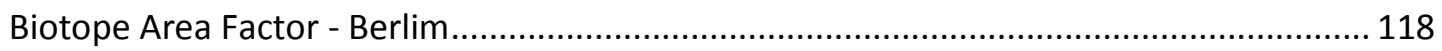

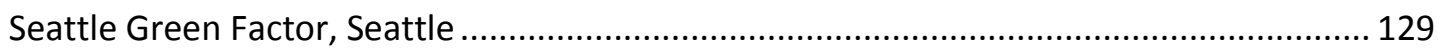

Green Space Factor \& Green Points System, Malmö, Suécia ........................................... 132

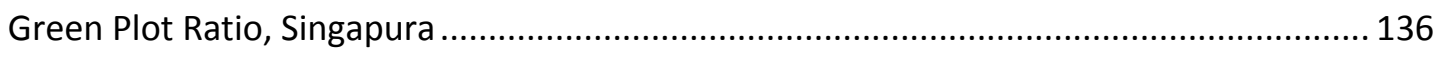

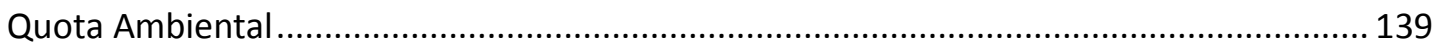

Considerações sobre as políticas de planejamento ambiental............................................ 146 



\section{INTRODUÇÃO E JUSTIFICATIVA}

O ambiente urbano possui características biofísicas diferentes do meio rural que o cerca. Isso inclui alterações nas trocas de energia geralmente levando ao aumento da temperatura do ar e das superfícies urbanas, e à diminuição do conteúdo de umidade. Estas alterações são, em parte, resultados da substituição de superfícies naturais por superfícies construídas; dessa forma, superfícies de concreto, asfalto e alvenaria contribuem para o acúmulo de calor, enquanto as áreas cobertas por vegetação se mostram eficientes na redução das temperaturas (EMMANUEL, 2005). Por exemplo, a diminuição da vegetação leva a uma redução das taxas de evaporação, enquanto um aumento de áreas impermeáveis aumenta as taxas de escoamento de águas pluviais (GILL et al., 2007). A sombra proporcionada pelo plantio de árvores no entorno dos edifícios beneficia a redução das temperaturas das superfícies verticais influenciando na temperatura interna da edificação, contribuindo para uma redução no uso dos sistemas de condicionamento artificial (VOOGT, 2007).

Os materiais de uso corrente no ambiente urbano, tais como concreto e asfalto, apresentam significativas diferenças nas suas propriedades térmicas (incluindo a capacidade de absorção e transmissão de calor) e propriedades radiativas da superfície (reflexão e emissividade) quando comparados com as áreas rurais (OKE, 1982). Em países de clima tropical, os tipos de revestimento de fachada desempenham um papel vital na regulação da temperatura e da quantidade de calor transmitido por um edifício (OTHMAN; SAHIDIN, 2016), sendo que os fenômenos de aquecimento urbano provocam, na maioria dos casos, impactos negativos na qualidade do ar e na saúde humana, principalmente entre crianças e idosos, pois o ar seco resseca nariz e garganta, favorecendo a ocorrência de doenças respiratórias, e o aumento no consumo de energia, para climatização artificial das edificações. Além disso, o aquecimento pode estar associado à formação da poluição, ligada às reações fotoquímicas dos poluentes presentes no ar, que ocorrem mais facilmente em altas temperaturas (WONG et al., 2010; PARAVANTIS et al., 2017). 
Em áreas altamente adensadas e poluídas a radiação solar recebida é reduzida entre 10 e $20 \%$ quando comparada a áreas rurais. O aquecimento radiativo é aumentado pelo calor antropogênico originado nos motores dos veículos, usinas de geração de energia, processos industriais e sistemas de condicionamento. As fontes de calor antropogênico podem ser consideradas, em muitos casos, comparadas em magnitude à radiação incidente (BONAN, 2008).

O nível de estresse térmico experimentado pelos pedestres em um ambiente urbano é afetado pelas trocas de energia com o entorno; um pavimento verde pode ter uma influência importante nesse cenário, principalmente em termos de radiação, absorvendo grande parte da radiação solar incidente. A evapotranspiração proporciona ainda uma capacidade da superfície se manter em temperaturas mais baixas do que as superfícies pavimentadas; embora existam diferenças térmicas entre os diferentes tipos de plantas, estas diferenças são desprezíveis quando comparadas às superfícies sem vegetação (SNIR et al., 2016).

O contato com a natureza gera também benefícios em relação à longevidade, doenças cardiovasculares, obesidade, saúde mental, qualidade do sono, recuperação de doenças e desfechos de natalidade. A presença de áreas verdes nos bairros, sejam parques, árvores ou outros tipos de vegetação traz efeitos positivos para saúde, não só de idosos, mas de todos os moradores vizinhos, sendo o impacto ainda maior em vizinhanças de renda mais baixa. As áreas verdes urbanas ajudam a reduzir a poluição do ar, regulam a umidade do ar e minimizam fenômenos de aquecimento urbano, além de diminuir o estresse, encorajar a atividade física e favorecer a interação social e a coesão da comunidade (SANTAMOURIS, 2014; BROWN et al., 2016).

Os benefícios do sombreamento proporcionado pela vegetação superam qualquer benefício de sombreamento proporcionado por elementos construídos; a vegetação também proporciona benefícios de desempenho adicionais para a edificação e para os seus ocupantes. Observando-se projetos concebidos para atender não apenas as questões relativas à edificação como também ao conforto do usuário, com estímulos à sua produtividade e criatividade, pode-se considerar que estes últimos são mais efetivos do que soluções focadas apenas em metas 
de desempenho da edificação construída, sendo capazes de aumentar a receita anual da empresa, reduzindo ainda seus custos de construção e operação. Um bom projeto arquitetônico com a inserção de vegetação localizada no entorno próximo, na fachada ou em áreas internas pode proporcionar economia de energia por consequência de sombreamento, além de proporcionar aos seus ocupantes a oportunidade de interagir diretamente com um ambiente restaurador, natural, gerando conforto e bem-estar e consequente melhora no desempenho do trabalhador, que pode ser mais eficaz do que soluções não interativas de projeto. Os efeitos psicológicos da inserção de vegetação são evidenciados com o aumento de produtividade, levando a economias que justifiquem os custos iniciais da construção (MANGONE; VAN DER LINDEN, 2014).

A vegetação proporciona muitos benefícios ambientais para a cidade, e o acesso diário à vegetação contribui para o bem-estar e o estado psicológico da população residente em centros urbanos. Incluir vegetação e usar materiais de maior albedo na construção civil são as estratégias são mais comumente utilizadas para atenuar os efeitos do aquecimento nas cidades (WONG et al., 2011).

Uma maneira de as cidades se adaptarem aos efeitos das alterações climáticas é através do incremento da sua infraestrutura verde para mitigar os impactos de ondas de calor e inundações. Uma estratégia para incrementar a infraestrutura verde nas áreas urbanas é manter a vegetação arbórea conectada entre pequenos parques urbanos, com arborização nas vias, formando uma rede de infraestrutura verde e densa na cidade, criando oportunidades de adaptação e provocando um efeito oásis nos dias de calor extremo; e também, indiretamente, para a mitigação dos fenômenos de aquecimento urbano, por diminuir as temperaturas de superfície pelo sombreamento, aumentando as perdas de calor por evaporação e, consequentemente, diminuindo o armazenamento de calor no tecido urbano (DUARTE, 2015). Uma pesquisa realizada em Roterdã visando conhecer o entendimento e as preocupações da população sobre os benefícios da infraestrutura verde para aliviar os impactos do aquecimento urbano, e as preferências das pessoas em relação às possibilidades de inserção de 
infraestrutura verde, demonstrou que os entrevistados tinham uma noção e preocupação com os impactos climáticos, mas não necessariamente tinham conhecimento de que a infraestrutura verde pode ajudar a resolver essas questões, o que sugere a importância da inclusão da população nas discussões relativas à incorporação da vegetação nas áreas urbanas (DERKZEN et al., 2017).

A radiação solar provoca o impacto mais significativo na sensação térmica humana em espaços ao ar livre; dessa forma, o sombreamento proporcionado pelas árvores ou abrigos se apresenta como a estratégia preferida de adaptação humana no estudo realizado por Yang et al. (2012) em Singapura. A vegetação pode reduzir a temperatura da superfície ao interceptar uma parte da luz solar incidente, através do sombreamento. Segundo Besir e Cuce (2018), um aumento na densidade de área foliar entre 13\% e 54\% proporciona uma redução na temperatura de superfície externa na faixa de $3,7-11,3^{\circ} \mathrm{C}$. A luz solar, assim absorvida pela vegetação, é parcialmente transformada em energia química através do processo de fotossíntese; outra parte da energia é transformada em calor latente, e a água é convertida em vapor pela evapotranspiração; dessa forma, embora as plantas tenham um albedo baixo, variando entre 0,15 e 0,25, absorvem quase tanta energia solar como o asfalto fresco. Sua superfície permanece muito mais fria, então menor quantidade de calor sensível é liberado para o ar. Um aumento na taxa de evaporação em áreas urbanizadas pressupõe um aumento de vegetação e dos corpos d'água, assim como uma maior retenção da água de chuva, e esse armazenamento pode ser incrementado também com superfícies urbanas mais porosas (ERELL, 2017; EMMANUEL, 2005).

O uso da vegetação no resfriamento das cidades contribui para a redução no consumo de energia nas edificações e a melhoria do conforto térmico para os usuários, chamando a atenção de pesquisadores nas últimas duas décadas, em grande parte, preocupados com as mudanças climáticas provocadas pelo aumento das taxas de urbanização. Diferentes formas de estruturas verdes têm sido estudadas, incluindo os parques urbanos, arborização de vias, telhados e fachadas verdes, observando-se que um incremento de 10\% na infraestrutura verde seria capaz de reduzir cerca de $2,5^{\circ} \mathrm{C}$ na temperatura média do ar, 
reduzindo a frequência e a magnitude do efeito ilha de calor (CAMERON et al., 2014). Esse fenômeno foi descrito por Oke (1987) como a diferença de temperatura do ar entre as áreas urbanas e rurais circundantes, quando as cidades são geralmente mais quentes, especialmente à noite (OKE 1987).

Por outro lado, o crescimento das metrópoles reduziu os espaços para as áreas verdes e o ambiente urbano criou vários obstáculos para o plantio de novas mudas como, por exemplo, a compactação do solo, o pouco espaço para crescimento das raízes, as instalações da rede elétrica e a falta do manejo adequado das árvores (DUARTE, 2015).

A cidade de São Paulo tem um dos índices mais baixos de vegetação por habitante do Brasil, apenas $14,02 \mathrm{~m}^{2}$ de área verde para cada habitante do município ${ }^{1}$, quando comparado com outras cidades como Maringá2 (31,5m²/hab) e Curitiba ${ }^{3}$ (64,5m²/hab). A vegetação no município de São Paulo apresenta-se distribuída heterogeneamente, o que torna a situação ainda mais crítica em áreas centrais, como se pode observar na Figura 1. Ao se verificar a quantidade de vegetação presente em bairros localizados em regiões de mais alta renda, com edificações de alto padrão, e se comparar com a quantidade de vegetação em bairros localizados em regiões mais periféricas, onde a população apresenta menor poder econômico, verifica-se que a quantidade de vegetação está diretamente ligada ao perfil socioeconômico da região analisada e os bairros de menor poder aquisitivo tem menor quantidade e qualidade de áreas verdes. Comparando-se ainda os mapas de perfil ambiental (2002) e socioeconômico (2000), disponíveis no Atlas Ambiental do Município de São Paulo, verifica-se que o coeficiente arbóreo ${ }^{4}$ se apresenta como eficiente indicador para estimativa de qualidade ambiental, apresentando a região mais nobre da cidade, a região centro-oeste, um dos mais elevados coeficientes arbóreos, acompanhada pela região sudeste e pela região sul, onde é definida a Área de Proteção aos Mananciais (HERMANN et al., 2003).

\footnotetext{
1 Disponível em http://www.redesocialdecidades.org.br/ Acesso em novembro de 2016.

2 Dados SAMPAIO, A.; ANGELIS, B.; Rev. SBAU, Piracicaba, v.3, n.1, mar 2008, p 37-57.

3 Dados da Prefeitura de Curitiba - medição por fotografia aérea concluída em dezembro de 2012.

${ }^{4}$ Relação percentual de área verde/ área urbana (HERMANN et al., 2003).
} 


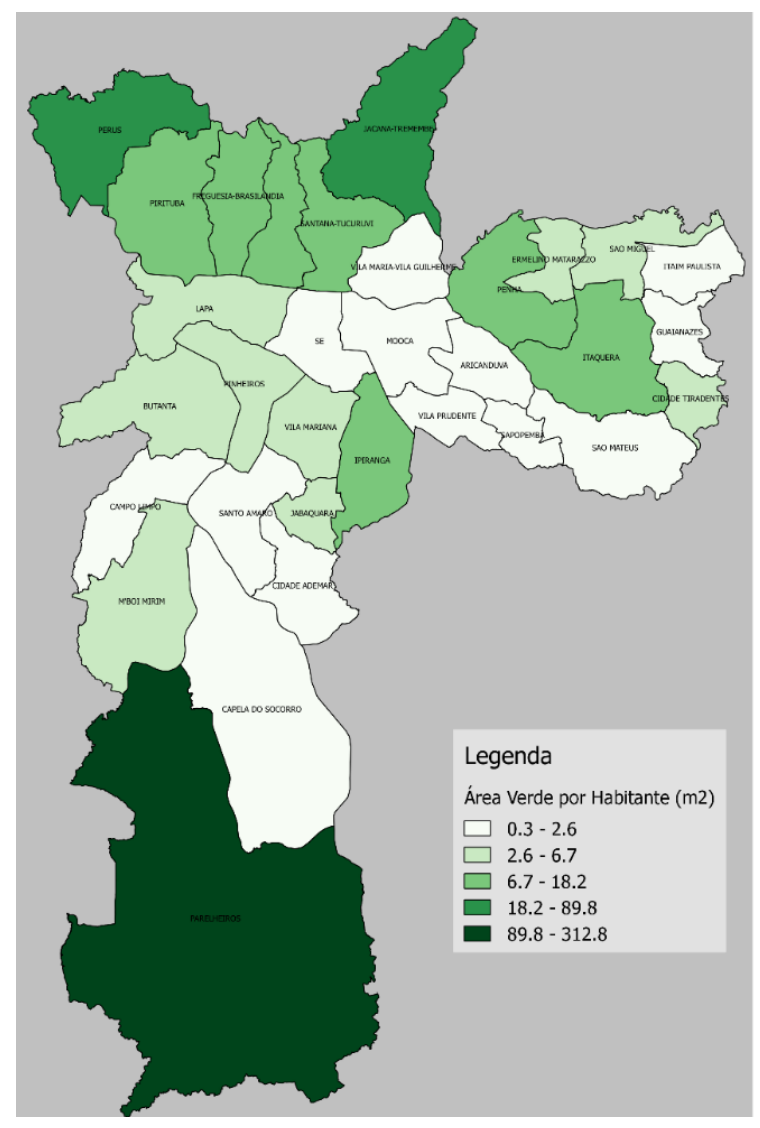

\section{Área verde por habitante -}

2011
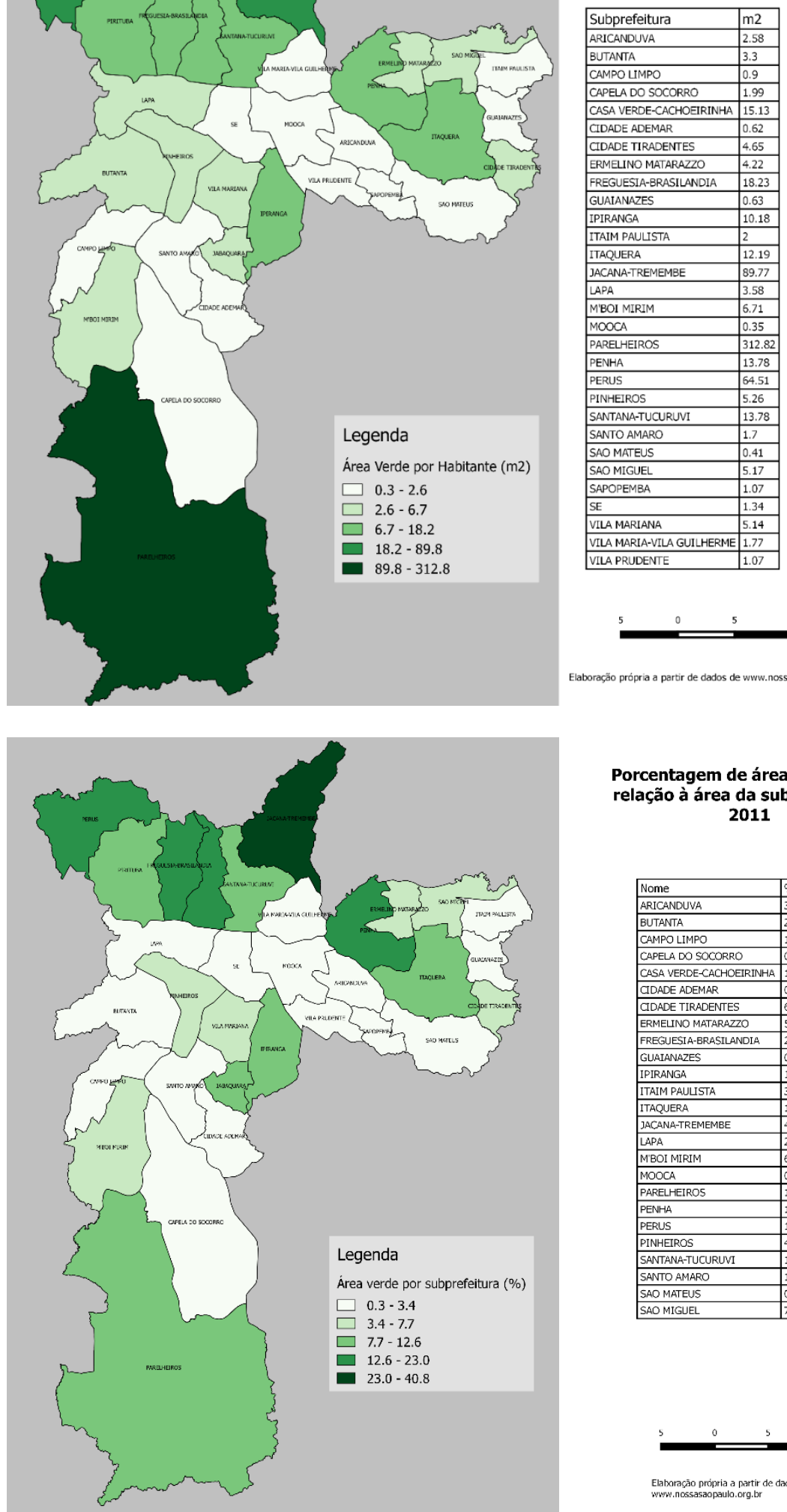

Porcentagem de áreas verdes em relação à área da subprefeitura -

2011

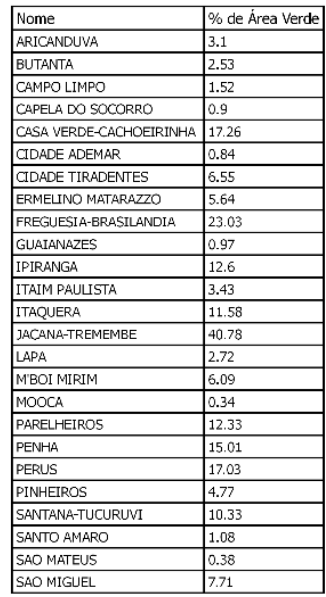

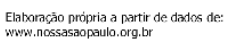

Figura 1- Porcentagem de área verde por habitante e em relação à área da subprefeitura na cidade de São Paulo, 2011. Fonte: dados disponíveis em www.nossasaopaulo.org.br, acesso junho de 2015, sobre base do Mapa Digital da Cidade (CESAD-FAU/USP e L. Ferreira, mapa elaborado originalmente para DUARTE, 2015). 
O processo de urbanização é um dos responsáveis pela supressão da cobertura vegetal em áreas urbanas. Como forma de remediar tais práticas que culminam cada vez mais na erradicação do verde na cidade, encontram-se ações que visam evitar, mitigar ou compensar tais impactos, como as políticas públicas de compensação ambiental em diferentes cidades do mundo, sistematizadas por Souza (2017).

A Secretaria Municipal do Verde e do Meio Ambiente - SVMA da Prefeitura Municipal de São Paulo usa atualmente como uma das alternativas de compensação ambiental ${ }^{5}$ a conversão de árvores em fundos para serviços ou obras, sendo necessário estabelecer melhores parâmetros para esse processo de conversão. Ferreira (2015) observa que a maioria dos acordos de compensação ambiental não tem contribuído para um aumento da cobertura arbórea existente, sugerindo que um aumento das restrições à remoção das árvores e a compensação ambiental monetária, dissociada de outras medidas, não garante a preservação da vegetação, aliada à falta de espaço físico para o replantio de árvores suprimidas pela implantação dos empreendimentos, especialmente em áreas de maior interesse para o mercado imobiliário de alta renda. Estes resultados sugerem a necessidade de um plano alternativo de orientação na remoção da árvore, compensação ambiental e replantio com base nos benefícios e nos custos ambientais da vegetação urbana, fazendo-se necessário compreender o valor da floresta urbana em São Paulo, e os impactos sociais e ambientais da sua remoção.

A supressão arbórea provocada pela implantação de empreendimentos imobiliários torna necessária a implementação de um mecanismo de compensação ambiental, visando à mitigação dos danos identificados no processo de licenciamento ambiental dos empreendimentos. A SVMA apresenta atualmente como alternativas de compensação ambiental a conversão de árvores em fundos (para serviços ou obras), ou em obras e serviços propriamente ditos, incluindo jardins verticais e coberturas verdes, conforme

\footnotetext{
${ }^{5}$ Nos casos de licenciamento ambiental de empreendimentos de significativo impacto ambiental, assim considerado pelo órgão ambiental competente, o empreendedor é obrigado a apoiar a implantação e manutenção de unidade de conservação do Grupo de Proteção Integral. (Artigo 36 Lei Federal oํ 9.985/2000).
} 
artigo 4ํำ do Decreto 53889 (São Paulo, 2015), que regulamenta o Termo de Compromisso Ambiental - TCA no município de São Paulo.

A legislação referente à supressão de vegetação no município de São Paulo gera dúvidas sobre os critérios considerados na definição de compensação ambiental. O estudo desenvolvido por Ferreira (2012), analisando o cenário da Vila Andrade, indica que o número de compensações ambientais não resultou no aumento da cobertura vegetal existente, evidenciando a necessidade de revisão na legislação atual.

O TCA, instituído pela Lei $\mathrm{n}^{\circ} 16.050$ de 31 de julho de 2014, artigos 154 e 155, alterados em 31 de setembro de 2014, determina:

“Art. 155, A compensação de remoção de espécimes arbóreos através de plantio dar-se-á por espécie de porte equivalente, vedada a compensação com o plantio de espécies meramente ornamentais, assim como em paredes e telhados.

Parágrafo único. Os recursos provenientes de Termos de Compromisso Ambiental (TCA) que disponham sobre compensação por supressão de vegetação em áreas iguais ou superiores a $25 \mathrm{~m}^{2}$, deverão ser utilizados exclusivamente em plantio de espécies arbóreas em terrenos públicos ou em logradouros do Município de São Paulo, ou para áreas destinadas exclusivamente para o plantio de espécies arbóreas."

Em 11 de março de 2015, foi publicado no DOM6 o decreto no 55994 de 10/03/15 que altera o artigo $4^{\circ}$ do Decreto 53889, que regulamenta o TCA no município de São Paulo, e que define:

"Art. 4 A conversão da compensação em obras e serviços, jardins verticais e coberturas verdes será admitida excepcionalmente, mediante decisão fundamentada do Colegiado da Câmara Técnica de Compensação Ambiental

${ }^{6}$ Disponível em < http://www.docidadesp.imprensaoficial.com.br/> Acesso em novembro de 2016. 
- CTCA, devendo a instrução processual conter, obrigatoriamente, como referência, o projeto e/ou o memorial descritivo, as especificações técnicas e a planilha de serviços com os valores da tabela oficial de custos unitários praticados pela Administração Municipal ou, na sua impossibilidade, orçamento a partir de pesquisa de mercado."

Esse decreto foi complementado em 19 de novembro de 2015 pelo decreto $\mathrm{n}^{0}$ 56630, que dispõe sobre a celebração de termos de cooperação com a iniciativa privada de que trata o artigo 50 da Lei no 14.223, de 26 de setembro de 2006, tendo como objeto a execução e a manutenção de jardins verticais, visando melhorias urbanas, ambientais e paisagísticas, que define:

"Art. $1^{\circ}$ A Secretaria Municipal do Verde e do Meio Ambiente - SVMA poderá celebrar termo de cooperação com a iniciativa privada que tenha por objeto a execução e manutenção, ou a manutenção, de jardins verticais."

Em 25 de novembro de 2016 foi publicado no Diário Oficial da Cidade de São Paulo, após o Parecer no 1601/2016 da Comissão de Constituição, Justiça e Legislação Participativa sobre Projeto de Lei no 0584/15, um incentivo à implantação de jardins verticais com a concessão de isenção parcial no valor do Imposto Predial e Territorial Urbano - IPTU, para os imóveis edificados que possuírem árvores e/ou áreas efetivamente permeáveis, com cobertura vegetal, dentro do perímetro do seu terreno, teto verde ou jardim vertical:

"Art. $5^{\circ}$ Fica concedida isenção de até 5\% (cinco por cento) no valor do IPTU para os condomínios verticais que possuírem jardim vertical.

$\S 1^{\circ}$ Considera-se jardim vertical como uma opção de paisagismo onde as plantas se desenvolvem numa parede externa da construção."

A compensação ambiental realizada em paredes, na cidade de São Paulo, tem sido questionada em várias esferas, incluindo o Ministério Público Estadual que determinou abertura de inquérito para apurar a instalação de jardins verticais em 
empenas cegas de edifícios ao redor do Elevado Presidente João Goulart, o Minhocão, alegando que a aplicação de receitas de compensações ambientais de empresas para essa ação, por parte da Prefeitura, configuraria desvio no uso dos recursos do Fundo Especial do Meio Ambiente e Desenvolvimento Sustentável - Fema?.

Essa possibilidade de conversão da compensação em jardins verticais proposta pela Prefeitura Municipal de São Paulo teve como seu primeiro projeto o Edifício Huds, localizado à Rua Helvetia, com $302 \mathrm{~m}^{2}$ de fachada verde, concluída em setembro 2015, e outras cinco fachadas concluídas nos edifícios Mackenzie, Santa Filomena, Santos, Santa Cruz e Bonfim, todas ao longo do Elevado Presidente João Goulart, o Minhocão, no centro de São Paulo. Em março de 2017 também foi aprovada uma compensação ambiental devida pela construção de um empreendimento residencial para viabilização de instalação de um muro verde na Avenida 23 de Maio, também em São Paulo.

O relatório final da comissão parlamentar de inquérito - $\mathrm{CPI}^{8}$ para averiguar eventuais irregularidades nos cumprimentos dos TCAs salienta que mesmo considerando o embelezamento paisagístico proporcionado pelos telhados e empenas verdes, os mesmos estão muito longe de equivaler às árvores adultas em serviços e ganhos ambientais. Jardins verticais diferem das árvores em massa foliar, realizando fotossíntese e evapotranspiração muito menores, e também pelo fato de não proporcionarem solo permeável e serem altamente dependentes de irrigação não natural. Buckeridge et al. (2018) ${ }^{9}$ salienta que também devem ser considerados na comparação entre jardins verticais e árvores urbanas o acúmulo de carbono e os serviços ambientais proporcionados. Enquanto nas árvores, o tronco é o principal elemento responsável pelo armazenamento de carbono, o mesmo não acontece nos jardins verticais, que não possuem troncos, apenas folhas e são formados por cerca de $98 \%$ de água

\footnotetext{
${ }^{7}$ RIBEIRO, B. Uso de verba para jardins verticais em São Paulo será investigado. Estadão, São Paulo, 18 ago. 2016. Disponível em < http://sao-paulo.estadao.com.br/noticias/geral,uso-deverba-para-jardins-verticais-sera-investigado,10000070280> Acesso em janeiro 2018.

8 SÃO PAULO (Cidade). Relatório Final da CPI-TCA. Para investigar eventuais irregularidades no cumprimento dos TCAs - Termos de Compromisso Ambiental. São Paulo 29 nov. 2016. Disponível em

<http://www.camara.sp.gov.br/wp-content/uploads/dce/RELAT\%C3\%93RIO_FINAL_CPI-

TCA.pdf> Acesso Janeiro 2018.

9 BUCKERIDGE, M.; LOCOSSELI, G.CARDIM, R. Árvores versus paredes verdes. Blog do Buckeridge. Disponível em: < https://msbuckeridge.wordpress.com/ >. Acesso em abril 2018.
} 
e acumulando, portanto, pouco carbono. Como benefícios ambientais das árvores para a qualidade de vida e saúde da população, podem ser citados: sombreamento, aumento da umidade do ar, redução de material particulado no ar, recarga de lençóis freáticos, entre outros. Enquanto os jardins verticais executados no Elevado Presidente João Goulart apresentam um custo de $\mathrm{R} \$ 800,00 / \mathrm{m}^{2}$ (valores de 2017), uma muda para compensação dentro dos padrões exigidos pela prefeitura municipal de São Paulo custa em média $\mathrm{R} \$ 150,00$ tomando-se como exemplo uma árvore da espécie Tipuana que quando adulta pode ocupar até $36 \mathrm{~m}^{2}$, tem-se a um investimento de apenas $\mathrm{R} \$ 4,00 / \mathrm{m}^{2}$. A possibilidade de realização de compensação ambiental em paredes, objeto de muitas críticas da comunidade científica, repercutidas pela imprensa ${ }^{10}$, peca também pela carência de mecanismos para manutenção, findo o prazo de apenas 6 meses sob responsabilidade da empresa, quando a Prefeitura deve assumir os custos, mesmo em se tratando de edifício privado. Jardins verticais são sistemas dependentes de tecnologias de suporte, nutrição e irrigação, necessitando, portanto, de cuidadosa manutenção. Mesmo com o plano estendido de manutenção apregoado em 2017, questiona-se a durabilidade desta situação a médio e longo prazos, numa cidade como São Paulo, onde historicamente a vegetação não recebe os cuidados necessários, gerando acidentes todo verão, surge a dúvida: como será a vida útil destes jardins verticais em 5, 10 anos? Uma árvore com essa idade está em pleno vigor, indo em direção à maturidade e normalmente sem necessidade de manutenções constantes e onerosas, como ocorre com os jardins verticais (BUCKERIDGE et al., 2018). Além disso, questiona-se ainda a durabilidade deste tipo de solução, como mencionado no relatório final da comissão parlamentar de inquérito, pois quando a compensação é realizada através do plantio de espécime arbóreo, na necessidade de supressão desse novo indivíduo deve-se fazer outra compensação e, assim, sucessivamente. Por outro lado, quando se fala de

10 MOURA, P. Jardins verticais de SP compensam apenas $23 \%$ das árvores desmatadas. UOL Notícias, São Paulo, 03 maio 2017. Disponível em <https://noticias.uol.com.br/meioambiente/ultimas-noticias/redacao/2017/05/03/jardins-verticais-de-sp-compensam-apenas-23das-arvores-desmatadas.htm> Acesso em janeiro 2018.

GERAQUE, E. Muro verde de Doria na av. 23 de Maio só teria valor ecológico com $1.500 \mathrm{~km}$. Folha de São Paulo. São Paulo, 04 de maio de 2017. Disponível em <http://www1.folha.uol.com.br/cotidiano/2017/05/1880911-muro-verde-de-doria-na-av-23-demaio-so-teria-valor-ecologico-com-1500-km.shtml> Acesso em janeiro 2018. 
compensação ambiental em paredes, nos acordos firmados com as empresas e condomínios que estão adotando este tipo de solução no Elevado Presidente João Goulart em São Paulo, constam que os termos de cooperação terão prazo máximo de validade de 3 (três) anos (Art. 14 do Decreto 56.630 de 19 de novembro de 2015); passado esse período os responsáveis pelo imóvel poderão decidir pela não continuação da cooperação e retirada das paredes verdes, fazendo com que exista um prazo de validade dessa vegetação e dos supostos benefícios por ela oferecidos.

Comparadas às coberturas, as fachadas verdes podem representar maiores superfícies em edifícios altos de áreas densamente ocupadas, a princípio incrementando a massa foliar e as trocas térmicas úmidas no seu entorno imediato, contribuindo assim para o balanço de energia nas áreas urbanas.

Sendo assim, para este trabalho foram realizados levantamentos da inclusão das paredes verdes nas políticas públicas ${ }^{11}$, das diferentes tecnologias de paredes verdes, além de estudos de desempenho microclimático de paredes verdes. Há uma série de trabalhos quantificando o efeito das superfícies verdes para 0 desempenho térmico dos edifícios, mas pouco se sabe sobre os efeitos microclimáticos urbanos das mesmas. Dentro desse contexto, o objetivo deste trabalho é quantificar o impacto das fachadas verdes no microclima urbano no nível do pedestre, considerando-se as variáveis temperatura e umidade do ar, temperatura de superfície e temperatura média radiante.

O capítulo 2 apresenta uma breve explanação sobre as tecnologias disponíveis para implantação de paredes verdes e suas limitações.

No capítulo 3 é apresentada a revisão da bibliografia, considerando-se os efeitos da vegetação no microclima e conforto urbano, balanço de energia, estudos que

${ }^{11} \mathrm{O}$ Apêndice 2 apresenta inciativas internacionais que incluem especificamente indicadores para inserção de vegetação para as seguintes cidades: Berlim, Alemanha (Biotope Area Factor); Seattle, EUA (Seattle Green Factor); Malmö, Suécia (Green Space Factor \& Green Points System); Singapura (Green Plot Ratio) e São Paulo (Quota Ambiental). 
consideram a vegetação incorporada à edificação, os modelos para estudo do impacto da vegetação no microclima e as lacunas de pesquisa no tema.

O capítulo 4, por sua vez, compreende o material e método, discorrendo sobre o ENVI-met, modelo escolhido para o desenvolvimento desta pesquisa, a medição microclimática realizada e a modelagem computacional.

O capítulo 5 é destinado à apresentação da análise dos resultados das simulações realizadas.

No capítulo 6 são apresentadas as considerações finais. 


\section{TECNOLOGIAS PARA IMPLANTAÇÃO DE PAREDES VERDES}

O revestimento de fachadas com vegetação se apresenta como um componente arquitetônico tradicional desde a antiguidade. Desde o século XIX no Reino Unido, na Europa e nas cidades norte-americanas as paredes verdes foram basicamente construídas com a utilização de plantas escaladoras. O projeto e a construção de fachadas verdes atuais pode aprender com a arquitetura tradicional e também incorporar materiais avançados e outras tecnologias nas construções (KÖHLER, 2008). Para Dunnett e Kingsbury (2008) todas as estruturas nas quais a vegetação pode se desenvolver podem ser consideradas possíveis para a inclusão de paredes verdes, tais como paredes em pedra e gabiões, além das paredes verdes construídas como estruturas independentes anexadas à fachada da edificação.

As paredes em pedra compõem a paisagem tradicional de diversas partes do mundo; são executadas, geralmente, com material advindo da própria região. Essas paredes normalmente não possuem argamassa de assentamento entre as rochas, permitindo a drenagem do solo adjacente, são particularmente apropriadas para o desenvolvimento de vegetação (Figura 2) e podem ser construídas em ângulo para uma maior estabilidade estrutural. $O$ fato das pedras estarem apenas justapostas se apresenta como uma grande oportunidade de fixação para as plantas nos vãos entre os blocos pois, uma vez construídas, as estruturas são naturalmente colonizadas pela vegetação. O princípio de empilhamento utilizado nas paredes em pedra consiste na utilização de blocos de dimensões variadas para preenchimento dos vãos, seus módulos geralmente apresentam pequenos orifícios pré-moldados através dos quais hastes de aço podem ser inseridas para reforço adicional (DUNNETT; KINGSBURY, 2008). 


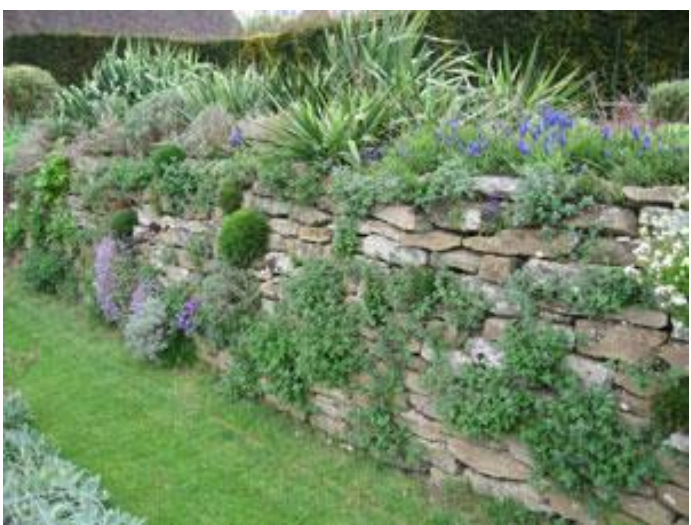

Figura 2 - Parede em pedra com vegetação. Disponível em: http://articles.extension.org/pages/13038/la ndscaping:-design-and-plant-selection. Acesso agosto 2017.

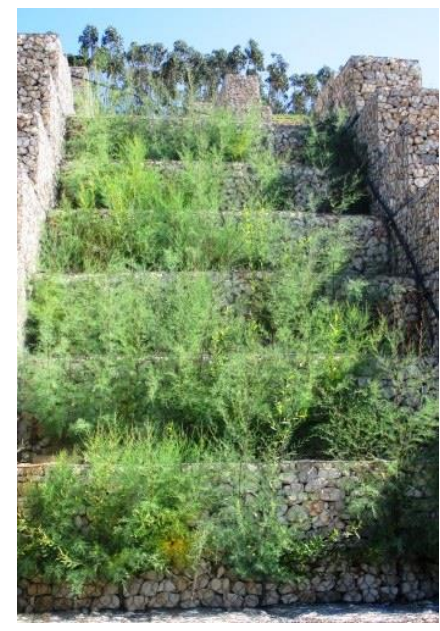

Figura 3 - Gabião com vegetação. Disponível em:

<http://www.isa.utl.pt/ceabn/projecto/1/78/proj ecto-de-estabiliza-ccedil-atilde-o-de-umtalude-na-a21-n-oacute-da-malveira-com-t eacute-cnicas-de-engenharia-natural>. Acesso agosto 2017.

Dunnett e Kingsbury (2008) sugerem que a vegetação pode ser mais rapidamente estabilizada com a utilização de gabiões do tipo colchão (Figura 3), onde pode ser utilizada manta geotêxtil, preenchida com uma mistura de pedras, rochas e substrato de crescimento. Gabiões em menor escala podem ser encontrados para a utilização em projetos paisagísticos e de jardins; geralmente as gaiolas apresentam dimensões reduzidas e o material de preenchimento é escolhido por razões estéticas e funcionais.

A correta implantação de sistemas de parede verde compreende diversos fatores: a estrutura de suporte apropriada, a quantidade adequada de água, oxigênio, nutrientes e níveis de $\mathrm{pH}$, a escolha das plantas que apresentam condições de sobrevivência às mudanças climáticas sazonais e às condições de iluminação do local; atender a todos esses fatores é essencial para que as paredes verdes possam se desenvolver (RILEY, 2017).

Estudos de caso realizados pelo Council on Tall Buildings and Urban HabitatSustainability Group (2014) demostraram que as características climáticas estão entre os fatores mais críticos que afetam os projetos das paredes verdes. Temperatura do ar, umidade do ar, velocidade do vento, radiação solar, cobertura de nuvens e precipitação são as variáveis capazes de afetar a escolha 
dos diferentes tipos de paredes verdes e a escolha das espécies. O estudo demonstrou que as paredes verdes podem ser utilizadas em diversos climas, tomando-se cuidado com a escolha das espécies, a orientação da fachada e a estratégia de irrigação adotada. A quantidade de radiação solar afeta diretamente a escolha das espécies e a orientação da parede verde; todas as plantas necessitam de luz, mas muita radiação direta pode ser prejudicial a diversas espécies. A quantidade de chuva incidente também é fator determinante para a escolha do sistema de irrigação e da espécie que será adotada na parede verde. A velocidade média do vento e o quanto a parede verde estará exposta ao vento também devem ser consideradas nas premissas de projeto, pois plantas geralmente sensíveis ao vento podem ser permanentemente danificadas pelo estresse causado pelo excesso de ventilação.

Madre et al. (2014) sugerem a utilização de espécies nativas para plantio em coberturas e fachadas verdes, possibilitando-se deixar algumas áreas somente no substrato, para permitir o desenvolvimento de espécies de plantas colonizadoras. Variações no tipo de substrato (solo, areia, cascalho, rochas), em diferentes profundidades em coberturas, também são recomendadas para criar maiores possibilidades de desenvolvimento de espécies nativas, além da implantação de reservatórios para favorecer o desenvolvimento de espécies de habitats úmidos. Os autores sugerem que a manutenção e irrigação devem ser limitadas para manter ou aumentar a diversidade de plantas, sugerindo a necessidade de uma nova percepção humana às paredes verdes, deixando de ser consideradas como "natureza virtual" e passando a ser concebidas como ecossistemas funcionais integrados à paisagem urbana.

Fatores limitantes para a implementação de fachadas verdes incluem espaço limitado no nível do solo e potencial para o crescimento vertical das espécies. Plantas escaladoras instaladas em suportes para fachadas podem alcançar entre $20 \mathrm{~m}$ e $30 \mathrm{~m}$ quando plantadas no solo, ou mesmo alcançar alturas maiores com a utilização de floreiras intermediárias na fachada, que devem ser integradas ao projeto do edifício (KÖHLER, 2008; DUNNETT e KINGSBURY, 2008). Fachadas verdes executadas através de sistemas de suporte modulares 
não apresentam limitações de altura; porém, o porte da vegetação adulta deve ser considerado nas fases de projeto.

Com o desenvolvimento da tecnologia de paredes verdes, a integração de diferentes estruturas em fachadas está se tornando cada vez mais popular. Essas estruturas aumentaram a velocidade de construção e a flexibilidade da fachada, tendo capacidade de receber espécies de plantas diversificadas (DAHANAYAKE; CHOW, 2017). A estrutura da edificação deve ser dimensionada para suportar as paredes verdes e sua carga extra, sendo que uma estrutura adicional pode ser prevista para suportar o peso extra no caso de edificações pré-existentes.

As fachadas verdes apresentam tipicamente vegetação do tipo escaladora lenhosa ou herbácea plantada no chão ou em floreiras, que podem ou não estar ligadas a sistemas de suporte, sendo que as floreiras requerem meios de cultivo específicos ou irrigação suplementar. Os sistemas de paredes vivas em painéis ou outras estruturas de ancoragem podem ser desenvolvidos em sistemas modulares ligados às paredes para facilitar o crescimento das plantas sem depender do espaço de enraizamento no nível do solo. Esta tecnologia permite uma maior variedade de formas de crescimento de plantas do que as fachadas verdes.

Existem diferentes tipos de sistemas verticais verdes, claramente distintos de acordo com seus sistemas construtivos; portanto, é necessário diferenciá-los e estudá-los separadamente.

Os sistemas de fachadas verdes e paredes vivas são apresentados na Tabela 1 e classificados, respectivamente, como extensivos e intensivos. Nos sistemas extensivos as fachadas verdes podem ser divididas em três diferentes sistemas: a) fachadas verdes tradicionais, onde as plantas escaladoras utilizam a própria parede como suporte (Figura 4), b) fachadas verdes duplas, com 0 objetivo de criar uma fachada verde distanciada da parede da edificação, onde as plantas utilizam estruturas de apoio independentes, como cabos (Figura 5), treliças modulares (Figura 6) ou malhas, onde plantas escaladoras ou arbustos suspensos crescem utilizando estruturas de apoio geralmente com a intenção de cobrir uma determinada área; e os sistemas intensivos, que podem ser divididos 
por sua vez em: a) floreiras perimetrais que servem para o plantio de vegetação no topo da parede e que deve se desenvolver criando uma cortina verde no sentido do topo para a base da parede e b) painéis em feltro geotêxtil (Figura 7). A vegetação pode estar plantada diretamente no solo, na base da estrutura ou em floreiras localizadas em diversas alturas da fachada, conforme se pode observar na Figura 8. Já nos sistemas intensivos as paredes vivas podem ter estruturas modulares ou sistemas de contêineres que compõem o revestimento das fachadas, conforme apresentado na Figura 9 (PÉREZ et al., 2011; OSMOND, P. e SHARIFI, E., 2017).

Tabela 1 - Classificação dos sistemas verticais para edificações.

Sistemas Extensivos

Fachadas

Tradicionais

Fachadas em pele Treliça modular

dupla ou "cortina verde"
Sistemas Intensivos

\begin{tabular}{|c|c|c|c|}
\hline \multirow[t]{3}{*}{ Fachadas Verdes } & \multicolumn{3}{|l|}{$\begin{array}{l}\text { Fachadas } \\
\text { Tradicionais }\end{array}$} \\
\hline & $\begin{array}{l}\text { Fachadas em pele } \\
\text { dupla ou "cortina } \\
\text { verde" }\end{array}$ & Treliça modular & \\
\hline & & $\begin{array}{l}\text { Malha com fio } \\
\text { direcionador }\end{array}$ & \\
\hline \multirow[t]{2}{*}{ Paredes Vivas } & & & $\begin{array}{l}\text { Floreiras } \\
\text { perimetrais }\end{array}$ \\
\hline & & & $\begin{array}{l}\text { Painéis em feltro } \\
\text { geotêxtil }\end{array}$ \\
\hline
\end{tabular}

Fonte: PÉREZ et al., (2011). 


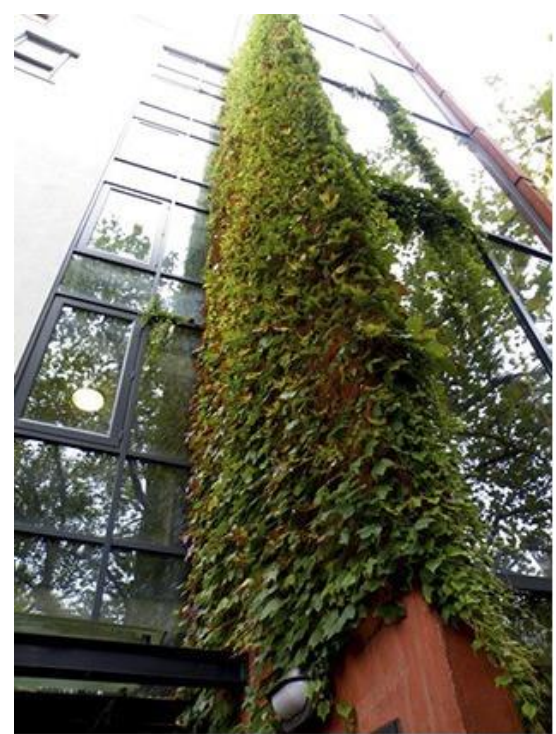

Figura 4 - Fachada verde tradicional. Disponível em

<http://www.clarkeassociates.cc> acesso em outubro 2016.

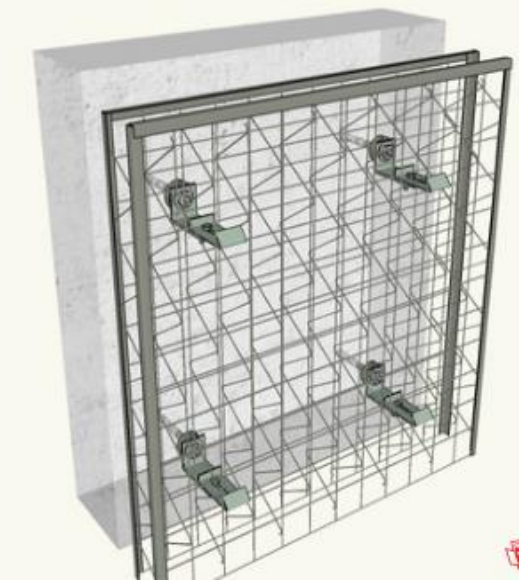

Figura 6 - Sistema de suporte modular. Disponível em

$<h t t p: / / g r e e n s c r e e n . c o m / \#>$ Acesso em outubro 2016.

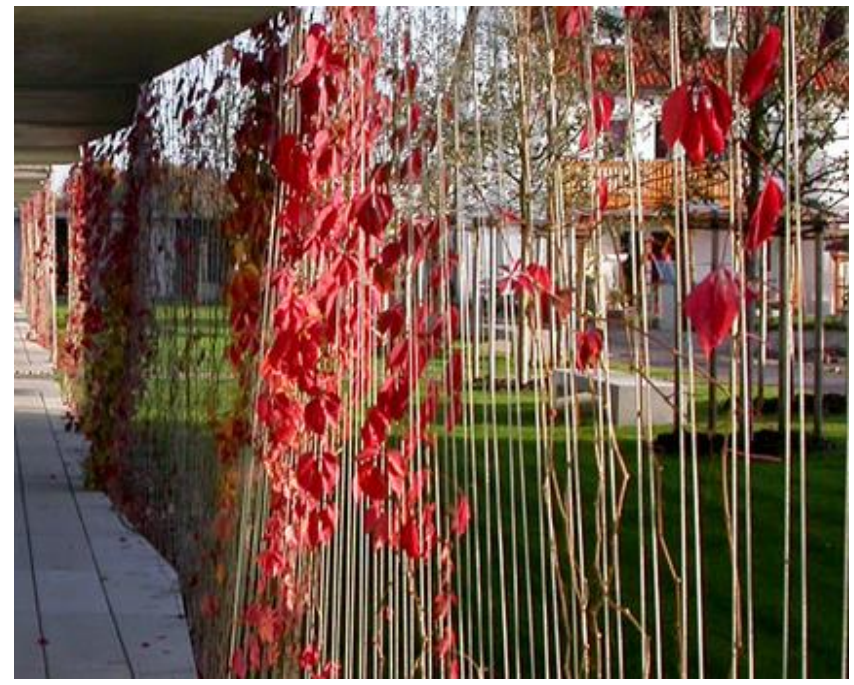

Figura 5 - Sistema de suporte com cabeamento. Disponível em <http://www.decorcable.com>

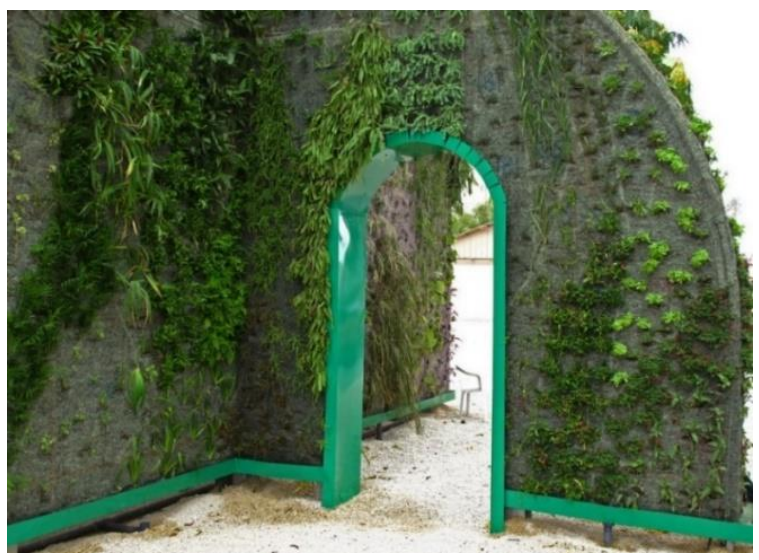

Figura 7 - Sistema de paredes vivas em feltro desenvolvido por Patrick Blanc. Fonte: https://www.verticalgardenpatrickblanc.com/. 


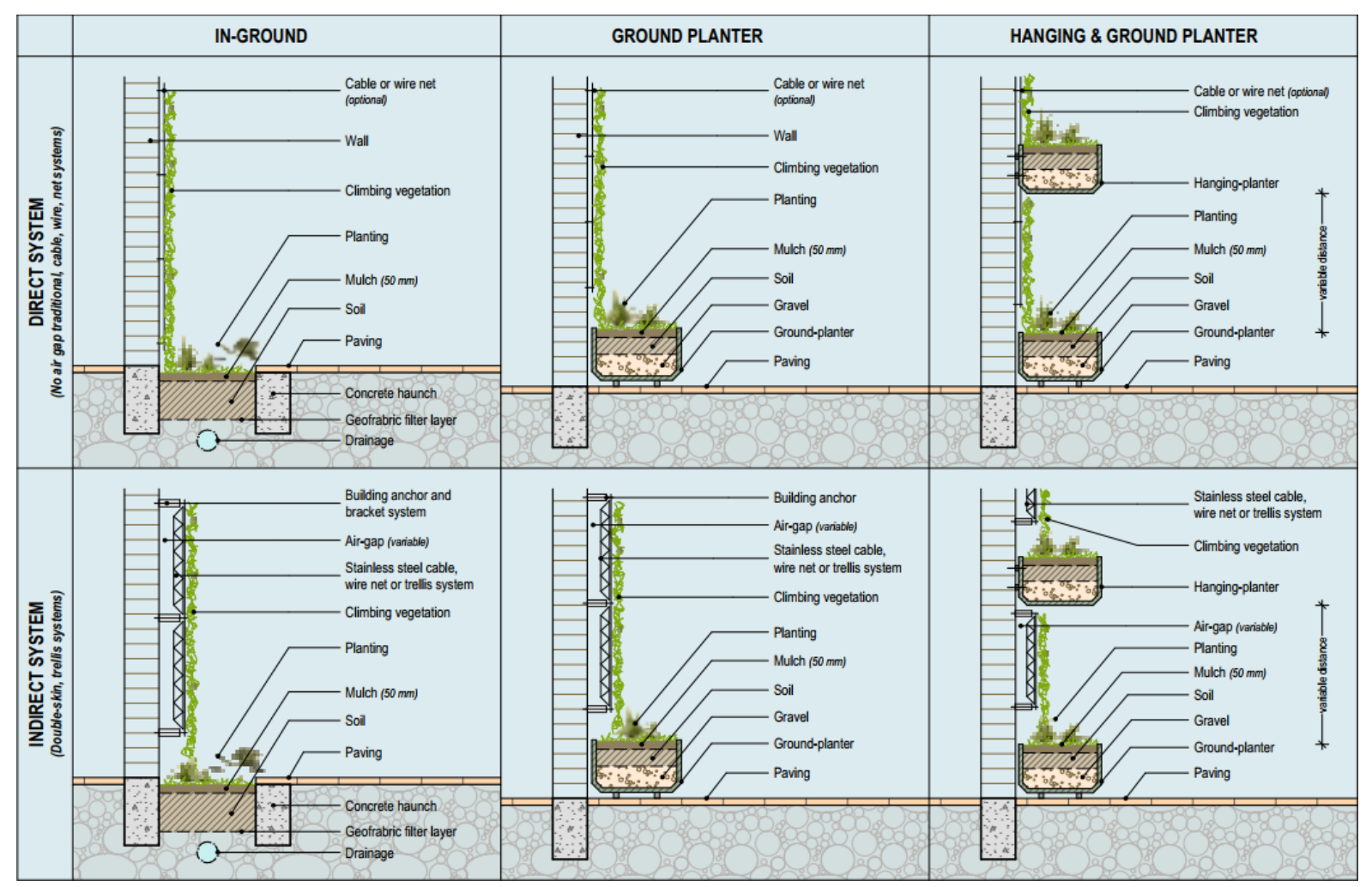

Figura 8 - Sistemas extensivos (fachadas verdes), segundo Osmond e Sharifi (2017)

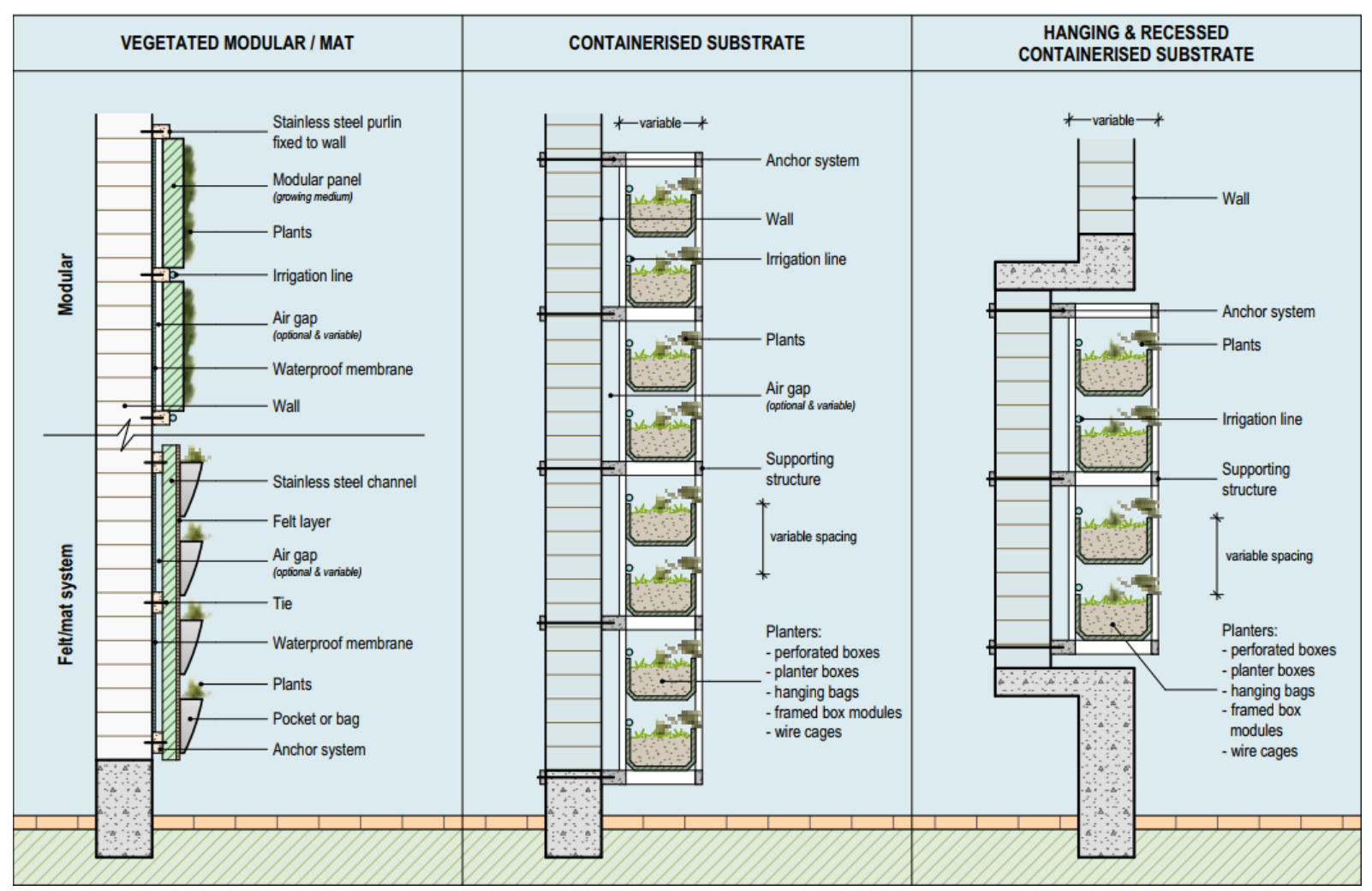

Figura 9 - Sistemas intensivos (paredes vivas), segundo Osmond e Sharifi (2017). 
O desempenho dos sistemas de fachadas verdes é influenciado pelo desenho e materiais utilizados na tipologia implantada, sendo que o sistema modular apresenta resultados mais efetivos de redução de temperaturas do que as paredes verdes com espécies escaladoras (JAAFAR et al., 2013).

Outra classificação possível para os sistemas de fachadas verdes se divide em sistemas diretos e indiretos

Figura 10), nos quais as fachadas verdes diretas são aquelas em que as plantas são unidas diretamente à parede e as fachadas verdes indiretas, por sua vez, incluem uma estrutura de suporte para a vegetação. Nesta classificação, os sistemas de parede viva são classificados como contínuos ou modulares, de acordo com o seu método de aplicação. Os sistemas contínuos de parede viva são baseados na aplicação de telas leves e permeáveis nas quais as plantas são inseridas individualmente; já os sistemas modulares apresentam diferenças na sua composição, peso e montagem, que podem ser na forma de bandejas, vasos, blocos para plantio ou bolsas flexíveis (MANSO; CASTRO-GOMES, 2015).

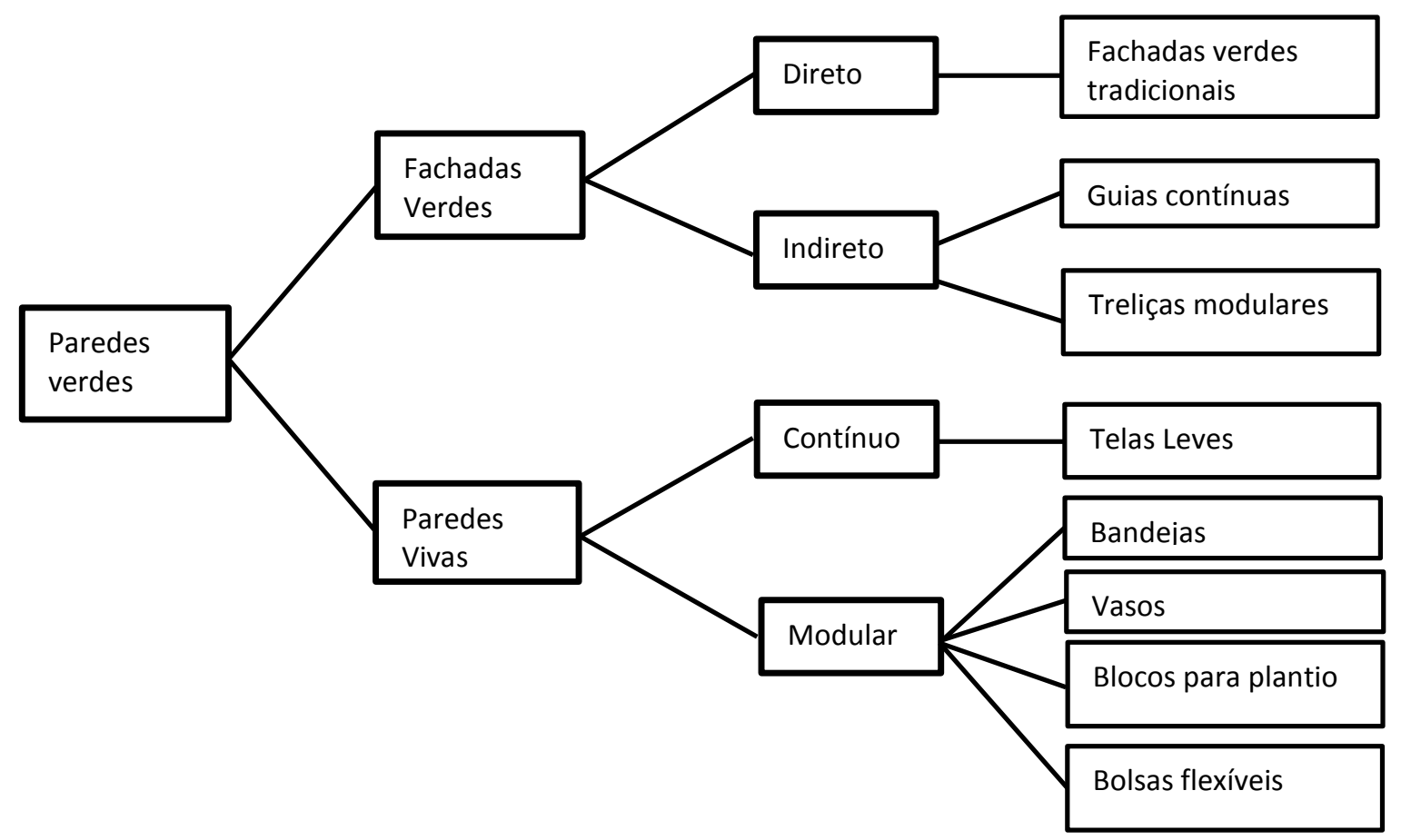

Figura 10 - Classificação das paredes verdes de acordo com suas características construtivas. Fonte: Manso et al. (2015). 
Escaladoras autoaderentes são capazes de cobrir áreas consideráveis; a capacidade de cobertura de diversas heras pode ser bastante útil na cobertura de fachadas cegas, em estágios iniciais; as escaladoras autoaderentes podem ser estimuladas com a utilização de treliças ou malhas realizando pressão sobre as mesmas para prendê-las à parede. Escaladoras por entrelaçamento, por sua vez, variam muito em tamanho, mas algumas espécies são capazes de chegar a 30m de altura; por sua tendência de crescimento vertical, torna-se difícil levalas ao longo de grandes áreas horizontais, ou qualquer apoio com ângulo inferior a $45^{\circ}$, demandando bastante manutenção, com podas e amarrações. Escaladoras por entrelaçamento, como a videira, aderem-se através de gavinhas ${ }^{12}$ quando os caules são jovens, aderência que pode durar vários anos, mas acaba finalizando, pois esses tentáculos servem apenas para auxiliar no crescimento da planta, não sendo capazes de suportar pesos muito elevados. Por esse motivo, nas fachadas verdes se faz necessário o uso de suportes que auxiliem vertical e horizontalmente, oferecendo a variedade de pegas necessárias, sendo que os elementos devem se cruzar em intervalos de $10 \mathrm{~cm}$ a $50 \mathrm{~cm}$ dependendo da espécie adotada (DUNNETT e KINGSBURY, 2008).

Segundo Dunnett e Kingsbury (2008) as escaladoras cipó e arbustos escandentes $^{13}$ não são escaladoras verdadeiras, uma vez que não apresentam sistemas de fixação sofisticados, utilizando-se muitas vezes de espinhos como forma de fixação. Apresentam crescimento rápido e longo, naturalmente arqueado pelo próprio peso, necessitando de apoio e amarrações para se sustentarem. Geralmente são utilizadas plantas escaladoras perenes nas fachadas verdes, mas também se pode optar por plantas sazonais e arbustos. As plantas sazonais podem prover coberturas temporárias, em situações onde se deseja uma cobertura foliar menor em determinado período, como no inverno, quando pode ser desejável a exposição da parede desprotegida da edificação ao sol. Para esses casos, arbustos são vegetações que crescem sem se fixar às paredes, necessitando de poda e de sistemas de fixação para se manterem próximos às paredes, mas podem apresentar os mesmos benefícios para as

\footnotetext{
12 Estrutura de adaptação do caule, com a função de agarrar elementos que sirvam de apoio para a planta em crescimento.

13 Plantas de caule lenhoso, com ramificações desde a base, características de arbustos com capacidade escaladora como as escaladoras.
} 
paredes verdes das plantas escaladoras, especialmente quando recebem manutenção e podas regulares.

As paredes vivas são um sistema relativamente novo, onde plantas se desenvolvem verticalmente em estruturas independentes anexadas à fachada da edificação. Geralmente dispõem de uma membrana impermeável para proteção da fachada e, além disso, as paredes verdes podem servir como solução técnica em contenção de encostas, onde a vegetação se torna parte integrante da estrutura (DUNNETT; KINGSBURY, 2008). Paredes vivas contínuas não necessitam de substrato e podem ser desenvolvidas sobre material geotêxtil, que serve como meio para o crescimento e fixação das raízes, onde a utilização de técnicas hidropônicas provê os nutrientes necessários ao desenvolvimento das espécies (CHAROENKIT; YIEMWATTANA, 2016). Os painéis podem ter diferentes tamanhos e tipos, com compartimentos onde 0 substrato e as plantas são posicionados e posteriormente fixados à parede.

Os sistemas geotêxteis são executados em feltro geotêxtil utilizado como suporte para plantas e musgos, e são sistemas ancorados diretamente na parede através de perfis metálicos (Figura 11). Difere dos sistemas de paredes vivas modulares que apresentam diversas possibilidades de configurações de plantio, com painéis únicos ou divididos em grades conforme apresentado na Tabela 2. Em painéis de grade, cada painel individual consiste em vários suportes, onde as plantas podem ser inseridas verticalmente ou em ângulo e cada componente é preenchido por solo ou substrato, fixado em uma estrutura de suporte (Figura 12). Este tipo parede viva apresenta a vantagem de proporcionar maior profundidade de plantio para o desenvolvimento das raízes e facilidade de substituição das plantas (CHAROENKIT; YIEMWATTANA, 2016). Nas configurações mais recentes observa-se a utilização de maiores recursos tecnológicos na implantação das paredes vivas, incorporando o substrato diretamente à envoltória, através de suportes modulares (PÉREZ et al., 2011). 


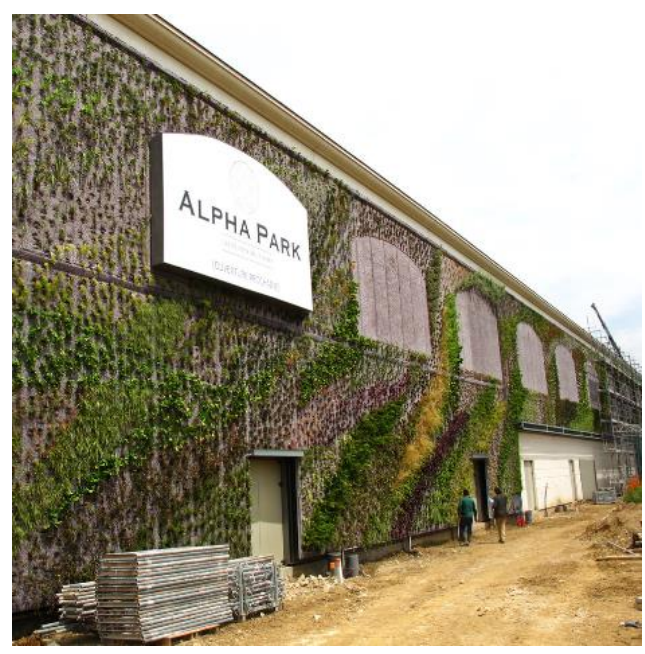

Figura 11 - Sistema de suporte geotêxtil. Disponível em $<h t t p: / / w w w . v e r t i c a l g a r d e n p a t r i c k b l a n c . c o m>$ acesso em outubro 2016.

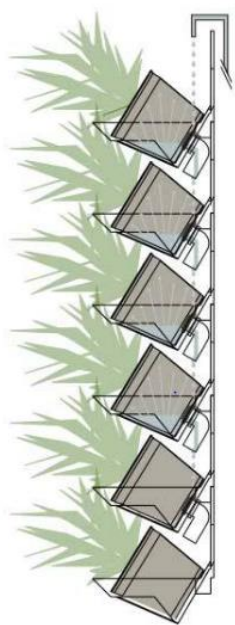

Figura 12 - Sistema de suporte modular. Disponível em <http://www.gsky.com> acesso em outubro 2016.

Tabela 2 - Classificação dos sistemas de paredes vivas.

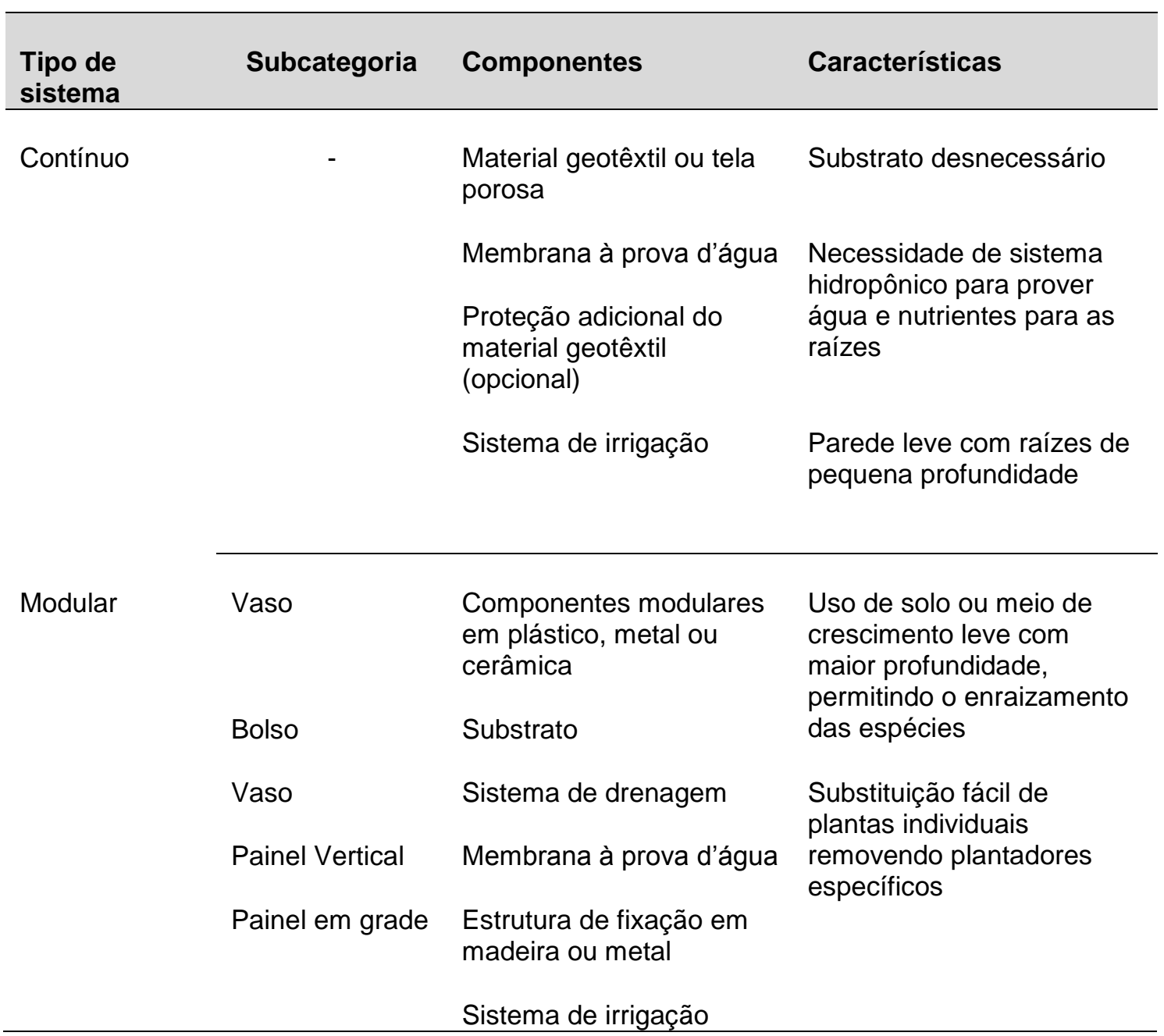


A escolha das espécies certamente é um ponto essencial para o sucesso do sistema, e a escolha adequada do substrato onde a vegetação estará inserida é fundamental, devendo preferencialmente ser composto por material inerte e não biodegradável, a fim de evitar a necessidade de substituição precoce, deve incluir um sistema de irrigação e distribuição de nutrientes, além de recipientes destinados ao plantio das espécies. Segundo Dunnett e Kingsbury (2008), sistemas hidropônicos se apresentam como uma possibilidade de desenvolvimento onde o sistema de irrigação provê todos os nutrientes necessários ao sucesso do crescimento das espécies.

Tabela 3 - Comparação de vantagens e desvantagens dos sistemas de paredes verdes.

\begin{tabular}{|c|c|c|c|c|}
\hline Sistema & Categoria & Subcategoria & Vantagens & Desvantagens \\
\hline \multirow[t]{10}{*}{$\begin{array}{l}\text { Fachadas } \\
\text { Verdes }\end{array}$} & Direto & $\begin{array}{l}\text { Fachadas } \\
\text { verdes } \\
\text { tradicionais }\end{array}$ & $\begin{array}{l}\text { Sem materiais } \\
\text { envolvidos } \\
\text { (suporte, meios de } \\
\text { cultivo, irrigação); }\end{array}$ & $\begin{array}{l}\text { Seleção limitada de } \\
\text { plantas / } \\
\text { adaptabilidade } \\
\text { climática; }\end{array}$ \\
\hline & & & $\begin{array}{l}\text { Baixa carga } \\
\text { ambiental; }\end{array}$ & $\begin{array}{l}\text { Desenvolvimento } \\
\text { vegetativo espontâneo }\end{array}$ \\
\hline & & & Baixo custo. & $\begin{array}{l}\text { Cobertura de } \\
\text { superfície lenta }\end{array}$ \\
\hline & & & & $\begin{array}{l}\text { Crescimento disperso } \\
\text { ao longo da superfície }\end{array}$ \\
\hline & & & & $\begin{array}{l}\text { Deterioração da } \\
\text { superfície / } \\
\text { desprendimento de } \\
\text { plantas }\end{array}$ \\
\hline & & & & $\begin{array}{l}\text { Problemas de } \\
\text { manutenção }\end{array}$ \\
\hline & Indireto & $\begin{array}{l}\text { Guias } \\
\text { Contínuas }\end{array}$ & $\begin{array}{l}\text { Orientação para o } \\
\text { desenvolvimento } \\
\text { da vegetação; }\end{array}$ & $\begin{array}{l}\text { Seleção limitada de } \\
\text { plantas / } \\
\text { adaptabilidade } \\
\text { climática; }\end{array}$ \\
\hline & & & $\begin{array}{l}\text { Baixo consumo de } \\
\text { água. }\end{array}$ & $\begin{array}{l}\text { Cobertura de } \\
\text { superfície lenta; }\end{array}$ \\
\hline & & & & $\begin{array}{l}\text { Crescimento disperso } \\
\text { ao longo da superfície; }\end{array}$ \\
\hline & & & & $\begin{array}{l}\text { Alta carga ambiental } \\
\text { de alguns materiais. }\end{array}$ \\
\hline
\end{tabular}




\begin{tabular}{|c|c|c|c|c|}
\hline & & \multirow{2}{*}{$\begin{array}{l}\text { Treliças } \\
\text { modulares }\end{array}$} & \multirow[b]{2}{*}{$\begin{array}{l}\text { Apoio leve; } \\
\begin{array}{l}\text { Orientação para o } \\
\text { desenvolvimento } \\
\text { da vegetação; }\end{array} \\
\text { Irrigação/drenagem } \\
\text { controladas; } \\
\text { Facilidade de } \\
\text { montagem e } \\
\text { desmontagem para } \\
\text { manutenção; } \\
\text { Substituição de } \\
\text { plantas. }\end{array}$} & \multirow[b]{2}{*}{$\begin{array}{l}\text { Seleção limitada de } \\
\text { plantas / } \\
\text { adaptabilidade } \\
\text { climática; } \\
\text { Alto peso ambiental } \\
\text { de alguns materiais; } \\
\text { Alto custo de } \\
\text { instalação. }\end{array}$} \\
\hline & & & & \\
\hline \multirow[t]{3}{*}{$\begin{array}{l}\text { Paredes } \\
\text { Vivas }\end{array}$} & Contínuo & Telas Leves & $\begin{array}{l}\text { Crescimento } \\
\text { uniforme; } \\
\text { Flexível e leve; } \\
\text { Aumento da } \\
\text { variedade de } \\
\text { plantas / potencial } \\
\text { estético; } \\
\text { Distribuição } \\
\text { uniforme de água e } \\
\text { nutrientes. }\end{array}$ & $\begin{array}{l}\text { Implantação } \\
\text { complexa; } \\
\text { Alto consumo de água } \\
\text { e nutrientes; } \\
\text { Manutenção } \\
\text { frequente; } \\
\text { Espaço limitado para } \\
\text { desenvolvimento de } \\
\text { raiz; } \\
\text { Alto custo de } \\
\text { instalação. }\end{array}$ \\
\hline & Modular & Bandejas & $\begin{array}{l}\text { Facilmente } \\
\text { desmontado para } \\
\text { manutenção; } \\
\text { Aumento da } \\
\text { variedade de } \\
\text { plantas / potencial } \\
\text { estético; } \\
\text { Irrigação / } \\
\text { drenagem } \\
\text { controlada. }\end{array}$ & $\begin{array}{l}\text { Implantação } \\
\text { complexa; } \\
\text { Soluções mais } \\
\text { pesadas; } \\
\text { Formas de superfície } \\
\text { limitadas às } \\
\text { dimensões das } \\
\text { bandejas; } \\
\text { Alto peso ambiental } \\
\text { de alguns materiais; } \\
\text { Alto custo de } \\
\text { instalação. }\end{array}$ \\
\hline & & $\begin{array}{l}\text { Blocos para } \\
\text { plantio }\end{array}$ & $\begin{array}{l}\text { Aumento da } \\
\text { variedade de } \\
\text { plantas / potencial } \\
\text { estético; }\end{array}$ & $\begin{array}{l}\text { Implementação } \\
\text { complexa; } \\
\text { Espaço limitado para } \\
\text { desenvolvimento de } \\
\text { raiz; }\end{array}$ \\
\hline
\end{tabular}




\begin{tabular}{|c|c|c|}
\hline & $\begin{array}{l}\text { Desenho atraente } \\
\text { de módulos. }\end{array}$ & $\begin{array}{l}\text { Formas de superfície } \\
\text { limitadas às } \\
\text { dimensões dos } \\
\text { blocos; } \\
\text { Alto custo de } \\
\text { instalação. }\end{array}$ \\
\hline $\begin{array}{l}\text { Bolsas } \\
\text { Flexíveis }\end{array}$ & $\begin{array}{l}\text { Adaptável a } \\
\text { superfícies } \\
\text { inclinadas; } \\
\text { Aumento da } \\
\text { variedade de } \\
\text { plantas / potencial } \\
\text { estético. }\end{array}$ & $\begin{array}{l}\text { Implementação } \\
\text { complexa; } \\
\text { Soluções mais } \\
\text { pesadas devido a } \\
\text { meios de cultivo } \\
\text { limitados à carga } \\
\text { máxima dos edifícios; } \\
\text { Alto custo de } \\
\text { instalação. }\end{array}$ \\
\hline
\end{tabular}

Fonte: Manso et al., (2015).

\subsection{LIMITAÇÕES DOS SISTEMAS DE PAREDE VERDE E FALHAS DE OPERAÇÃO}

A escolha do sistema de suporte apropriado para o tipo de planta escolhido e sua correta instalação é indispensável para o sucesso e segurança de uma fachada verde. Dunnet e Kingsbury (2008), observam que os problemas apresentados pelos sistemas de suporte geralmente são causados pelos seguintes fatores: o sistema de suporte instalado é insuficiente para a espécie escolhida; a fixação dos suportes não é executada adequadamente; o projeto do sistema de suporte não considera adequadamente o porte das espécies adultas.

Nos casos em que as plantas excedem a altura de dois pavimentos, os mesmos autores ressaltam a necessidade do conhecimento prévio do porte da planta adotada e seus hábitos de crescimento, fatores diretamente relacionados às capacidades ao sistema de suporte adotado. A altura máxima deve ser realisticamente estimada, chegando em média a $24 \mathrm{~m}$, ou cerca de oito pavimentos, embora algumas espécies possam chegar a $30 \mathrm{~m}$. A frequência de manutenção deve levar em conta o porte da espécie e também o tipo de suporte utilizado; uma manutenção insuficiente para o tamanho do suporte pode conduzir 
ao autoestrangulamento e crescimento pouco atraente das espécies; um crescimento emaranhado pode levar ao excesso de carga pela vegetação e também pela ação dos ventos, assim como um crescimento indesejado sobre aberturas e calhas. 


\section{OS EFEITOS DA VEGETAÇÃO NOS MICROCLIMAS URBANOS}

Estratégias capazes de atenuar o estresse provocado pelo calor em áreas urbanas serão cada vez mais necessárias, devido aos efeitos do aquecimento urbano agravados também pelas mudanças climáticas globais.

Oke et al. (2017), constatam que o microclima urbano é resultante da paisagem e funções urbanas, apontando que um desenho urbano sensível ao clima, pode moderar os riscos causados pelas mudanças climáticas, limitar a utilização de recursos e também de emissões de poluentes, além de proporcionar maiores períodos de conforto ao ar livre. Entre todos os elementos urbanos, a vegetação é o mais versátil a serviço da alteração do clima, podendo ser utilizada no controle das trocas de radiação, evaporação, proteção contra o vento excessivo, danos provocados pelo escoamento das águas superficiais, erosão e melhora dos níveis de ruído.

\subsection{O BALANÇO DE ENERGIA EM ÁREAS URBANAS E O PAPEL DA VEGETAÇÃO}

As diferenças de temperatura do ar e superficial encontradas nas áreas urbanas são atribuídas à geometria urbana, influenciadas pelo tamanho, forma e orientação dos edifícios e ruas, e também à natureza das superfícies urbanas, seu albedo, sua capacidade térmica, condutividade térmica e umidade. Estas características alteram o balanço de radiação na superfície, o armazenamento de calor no tecido urbano e a partição da energia em calor latente e sensível (OKE, 1982).

A Figura 13 apresenta uma comparação de balanços de energia de forma esquemática em área urbana e rural, sendo que a área rural de pastagem apresenta albedo um pouco maior do que a área urbana. Dessa forma, mais radiação solar é absorvida na superfície e a área urbana tem um saldo de 
radiação ligeiramente superior ao da área rural. A maior parte do saldo de radiação na área rural (66\%) é devolvida à atmosfera como calor latente, $30 \%$ é devolvida como calor sensível e apenas $4 \%$ é armazenado no solo. Em contraste, apenas $34 \%$ do saldo de radiação na área urbana é perdida como calor latente, $44 \%$ é devolvido como calor sensível e $22 \%$ é armazenado no tecido urbano. Ao longo do dia, a área urbana apresenta um fluxo de calor sensível 50\% maior e um fluxo de calor latente $46 \%$ menor em comparação com a área rural. Como resultado, a área rural apresenta menor temperatura e maior evapotranspiração que a área urbana (BONAN, 2008).

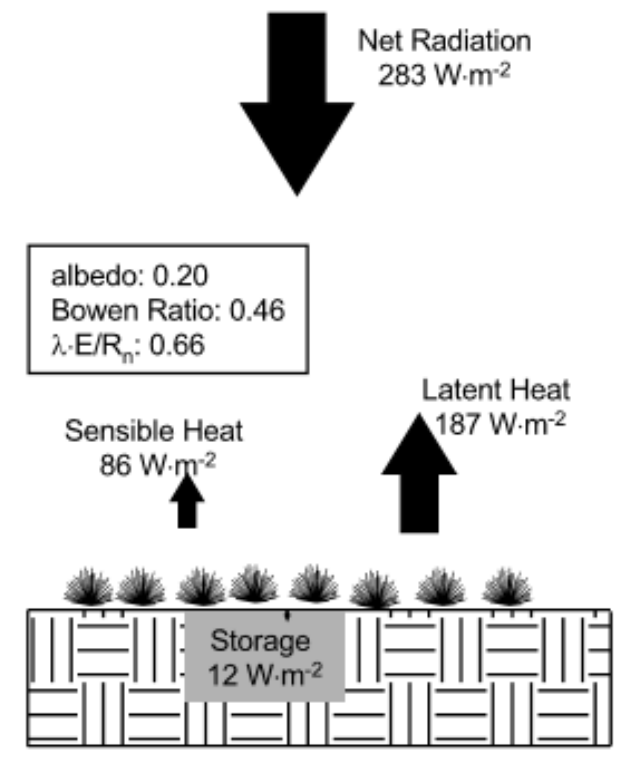

Rural Site managed grassland

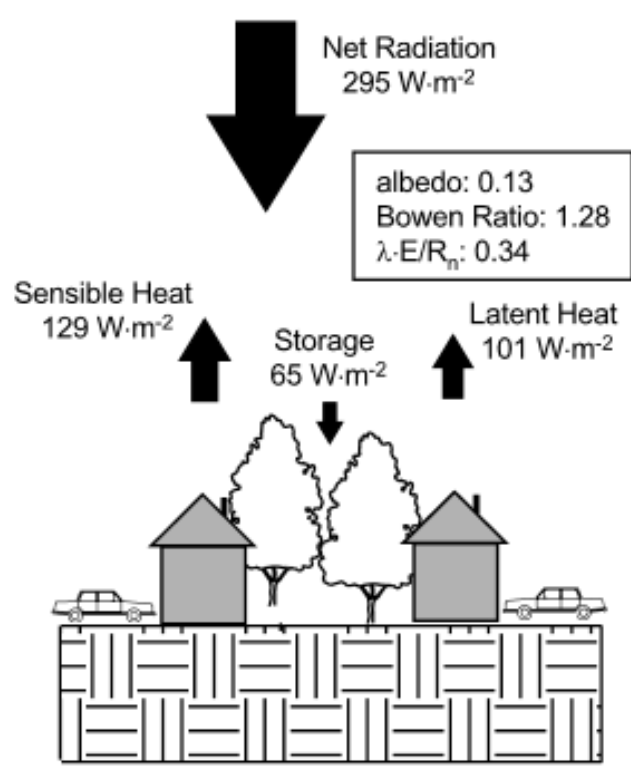

Suburban Site $25 \%$ building $11 \%$ paved $64 \%$ greenspace

Figura 13 - Balanço de energia no período diurno de um dia de verão (Bonan, 2008).

O dossel urbano é caracterizado por uma complexidade considerável. A unidade principal de modelo do cânion urbano consiste no conjunto formado pelas paredes e pelo piso, caracterizado normalmente por uma via entre dois edifícios. O cânion contém um volume que tem três lados com superfícies ativas (paredes e piso), e três lados abertos (sendo uma cobertura imaginária perto do nível do telhado e as outras duas, as extremidades ao longo do cânion onde o fluxo pode ocorrer). Este arranjo reconhece a natureza tridimensional do dossel urbano e permite a inclusão da interação entre edifícios ao invés de tratá-los como objetos isolados. Numa cidade com um padrão de urbanização ortogonal, há duas 
orientações de cânion perpendiculares, e cada uma terá um microclima diferente devido às diferenças no ângulo de incidência solar e no ângulo de ventilação. Essas diferenças são adicionais às criadas pelas características radiativas, térmicas e de umidade de seus materiais de construção, e pela geometria do cânion (OKE, 2002).

A inserção de um edifício na paisagem dá origem a modificações radiativas, térmicas, hídricas e aerodinâmicas do ambiente circundante. Os efeitos radiativos mais importantes são a diminuição da incidência de radiação solar nas áreas sombreadas pelo edifício, um aumento local na incidência solar por reflexão de paredes iluminadas pelo sol e diminuição da perda por ondas longas de superfícies próximas ao edifício, causada pela redução do fator de visão do céu; também ocorre nas imediações de um edifício um aumento nas temperaturas do solo e do ar devido às perdas de calor do edifício e à menor perda convectiva, como resultado de uma interceptação dos ventos. O balanço hídrico em torno de um edifício é alterado por causa da variabilidade espacial na recepção de precipitação, drenagem do solo e evaporação (OKE, 2002).

Na ausência de advecção, a temperatura do ar é governada principalmente pelo balanço de energia na superfície. Uma superfície urbana quente liberará mais calor sensível, que é transferido por convecção, do que uma superfície mais fria exposta às mesmas condições ambientais. Por sua vez, as plantas podem reduzir a temperatura da superfície reduzindo a exposição à luz solar ou por resfriamento evaporativo (ERELL, 2017).

A simples substituição do solo nu ou pavimento por grama é suficiente para reduzir a carga térmica recebida por uma pessoa em pé em até 200 watts, resultando em uma mudança de sensação térmica de "muito quente" para "quente". Essa melhoria é quase inteiramente devida à redução da radiação de onda longa emitida pela superfície, já que a cobertura vegetal se apresenta mais fria do que o pavimento de solo ou concreto. A adição de indivíduo arbóreo proporciona redução significativa do estresse térmico, proporcionando uma redução de cerca de $70 \%$ na radiação solar devido ao sombreamento, apresentando uma contribuição importante para a melhoria do conforto térmico em climas quentes. Este efeito é frequentemente atribuído à redução da 
temperatura do ar, que geralmente é de baixa magnitude. O efeito da vegetação de superfície nas trocas radiantes é muitas vezes mais significativo. A vegetação combina um albedo baixo com uma temperatura superficial baixa; a cobertura vegetal reflete cerca de $20 \%$ da luz solar incidente, aproximadamente a mesma quantidade que o asfalto envelhecido, porém, emite muito menos radiação infravermelha (ERELL, 2017).

\subsection{A INFLUÊNCIA DA VEGETAÇÃO NO MICROCLIMA E NO CONFORTO TÉRMICO URBANO}

Coutts et al. (2016) em seu estudo para a cidade de Melbourne, Austrália, que estabeleceu como meta o aumento da cobertura do dossel dos atuais $22 \%$ até $40 \%$ em 2040, observaram que é necessário cuidar e manter a vegetação arbórea urbana para garantir a contribuição dos benefícios proporcionados pelas árvores na melhoria do microclima urbano em dias quentes. Devido à natureza variável e localizada dos benefícios de sombreamento e evapotranspiração das árvores para os cânions urbanos, os autores sugerem que a vegetação esteja distribuída por toda a paisagem urbana para melhorar as condições do microclima e o conforto térmico humano. Em dias muito quentes, as árvores em calçadas podem diminuir o nível de estresse pelo calor no período diurno, através de uma redução na temperatura radiante média proporcionada pelo sombreamento das copas. Os autores sugerem ainda que árvores distribuídas estrategicamente onde as pessoas estão mais suscetíveis a serem expostas a níveis elevados de radiação solar no período diurno (como praças, corredores de transporte, curtas rotas de caminhadas e áreas de serviços públicos como escolas e hospitais) ajudam a construir uma cidade mais resiliente ao clima com níveis reduzidos de estresse térmico durante o dia no verão, o que justifica o argumento para o aumento do investimento no plantio de árvores, manutenção e proteção por conselhos locais.

Zölch et al. (2016) comparam três opções de infraestruturas verdes urbanas: árvores, tetos e fachadas verdes. Seu desempenho foi avaliado de acordo com 
a situação atual e futura através de modelagem computacional com o modelo ENVI-met para a cidade de Munique, Alemanha. Os resultados obtidos revelaram que a magnitude do arrefecimento diferia amplamente entre os cenários investigados, sendo o desempenho das árvores o melhor observado, proporcionando uma redução de 13\% na Temperatura Equivalente Fisiológica PET (Physiological Equivalent Temperature), devido à grande área de sombreamento proporcionado pelas copas. O estudo apresenta sugestões e estratégias para definição dos tipos de infraestrutura verde nas áreas mais expostas ao efeito do calor, priorizando a plantação de árvores em pontos mais críticos a fim de contribuir com a redução da radiação solar incidente sobre superfícies artificiais, e aumentar o efeito do arrefecimento por evapotranspiração em lugares com circulação de pessoas.

O mesmo estudo sugere a utilização de fachadas verdes como reforço aos efeitos de mitigação, por terem apresentado arrefecimento entre 5 e $10 \%$ do $\mathrm{PET}$, em particular em áreas onde existe a impossibilidade de plantio de árvores devido à densidade construída e usos competitivos. Os tetos verdes são considerados pelos autores como estratégias multifuncionais para prover jardins de cobertura adicionais, com capacidade para contribuir na redução do escoamento de águas pluviais, e na promoção da biodiversidade, embora o estudo tenha mostrado que tetos verdes apresentam a contribuição menos expressiva para a compensação dos efeitos das mudanças climáticas, dentre as três estratégias de infraestrutura verde estudadas (ZÖLCH et al., 2016). A Figura 14 apresenta uma síntese dos benefícios da vegetação, dos efeitos da umidade e consequentemente da evapotranspiração nas condições de conforto térmico humano, levando em consideração as variáveis temperatura, umidade, ventilação e o acesso ao sol, para o contexto australiano em uma situação de verão em duas paisagens: uma paisagem urbana convencional e uma paisagem urbana com presença significativa de elementos com maior capacidade de absorção hídrica (COUTTS et al., 2013).

Na paisagem urbana convencional, durante o dia se faz necessária a introdução de vegetação para promover sombra e evapotranspiração, e para amenizar as temperaturas de superfície a fim de se reduzir as emissões de calor por radiação 
de onda longa sobre os pedestres. No período noturno, outra necessidade da paisagem urbana convencional é promover o resfriamento das superfícies e do ar, por meio da emissão de radiação de onda longa pelas superfícies, incrementada pela ventilação.

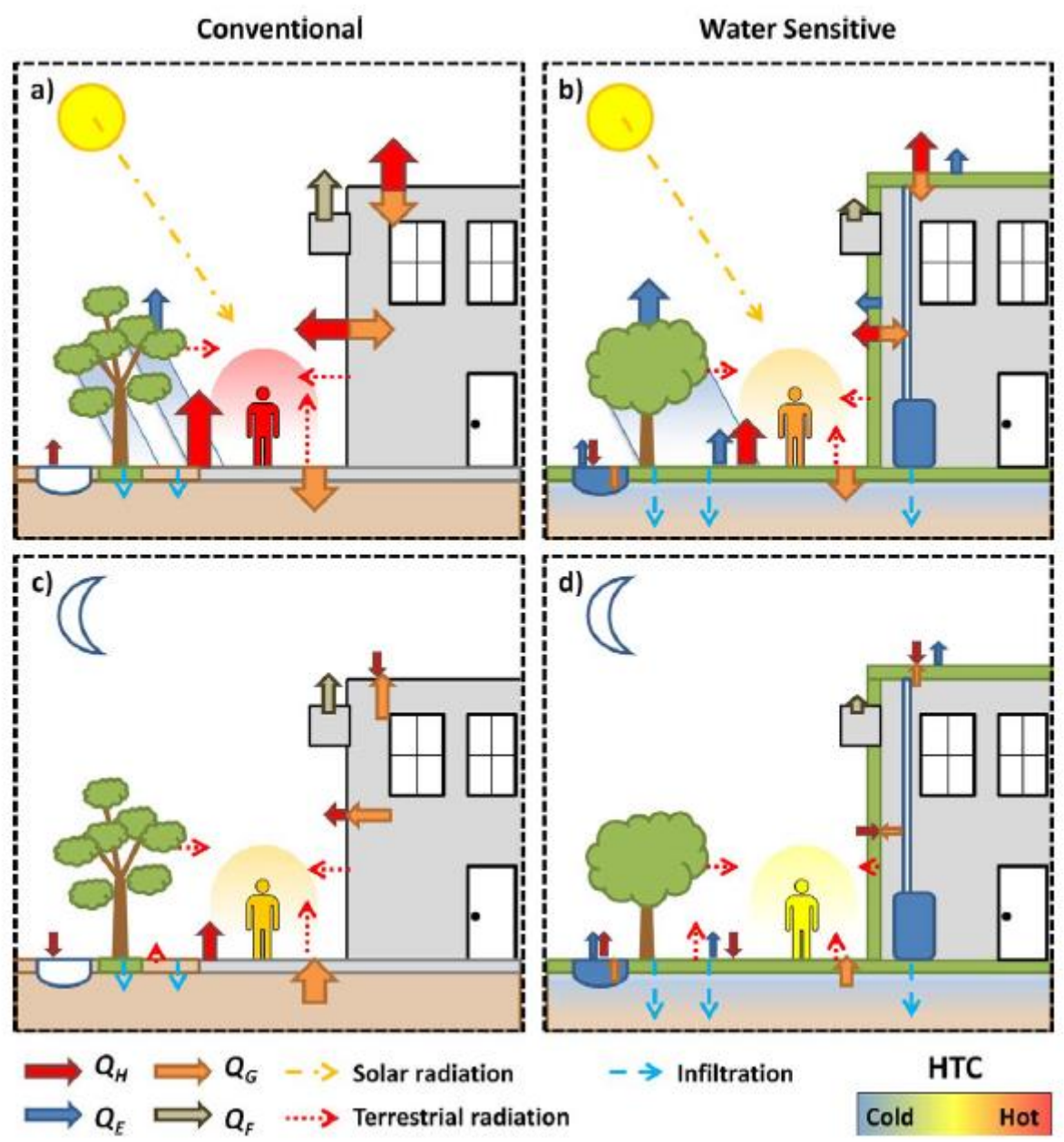

Figura 14 - Generalização dos processos-chave na formação de microclimas urbanos durante o verão para paisagens urbanas convencionais (disponibilidade de água limitada) ( $A$ e $C$ ) e paisagens urbanas com maior capacidade de absorção hídrica ( $B$ e $D$ ), nos períodos diurno e noturno. Fonte: COUTTS et al. (2013).

A arborização de rua traz benefícios ambientais, sociais e econômicos para as cidades. O papel das árvores de rua em Melbourne, na Austrália, e suas contribuições para a redução da temperatura do ar, temperatura de superfície e temperatura radiante média dos microclimas urbanos e para a melhoria do conforto térmico humano foram comparadas em três ruas com orientação LesteOeste. Foram estudadas duas geometrias de cânion contrastantes (muito profundos e pouco profundos) e também dois dosséis contrastantes (alto 
e baixo). Essas ruas foram instrumentadas com várias estações de monitoramento microclimático para medir continuamente a temperatura do ar, umidade do ar, radiação solar, velocidade do vento e a temperatura radiante média, de modo a se calcular o Índice Termo Climático Universal - UTCI (Universal Thermal Climate Index) entre maio de 2011 e junho de 2013. Observase, na Figura 15, que as árvores de rua proporcionaram um resfriamento médio diurno durante os eventos de calor no cânion pouco profundo variando entre $0,2^{\circ} \mathrm{C}$ e $0,9^{\circ} \mathrm{C}$ na temperatura do ar, no período entre 9:00h e 10:00h. O arrefecimento diurno máximo atingiu $1,5^{\circ} \mathrm{C}$ no cânion pouco profundo. No caso do cânion profundo a influência de copas de árvores de rua foi mascarada pelo efeito de sombreamento dos edifícios altos. As árvores foram muito eficazes na redução do UTCI diurno no verão em grande parte devido a uma redução na temperatura radiante média na sombra, reduzindo o stress térmico de muito forte $\left(\mathrm{UTCl}>38^{\circ} \mathrm{C}\right)$ até forte $\left(\mathrm{UTCl}>32^{\circ} \mathrm{C}\right)$. A influência das árvores de rua na temperatura do ar do cânion e UTCI foi altamente localizada e variável, dependendo da cobertura da árvore, da geometria e das condições meteorológicas prevalecentes. (COUTTS et al., 2016).

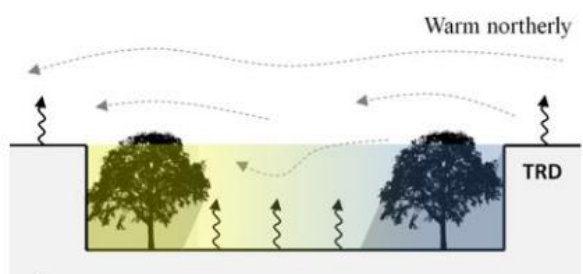

a)

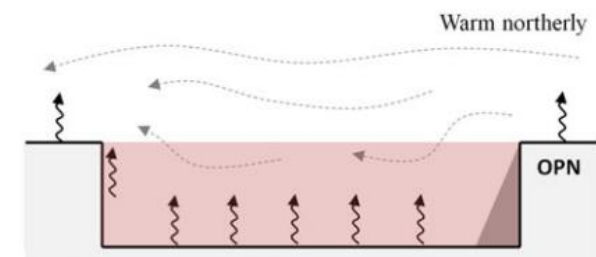

b)
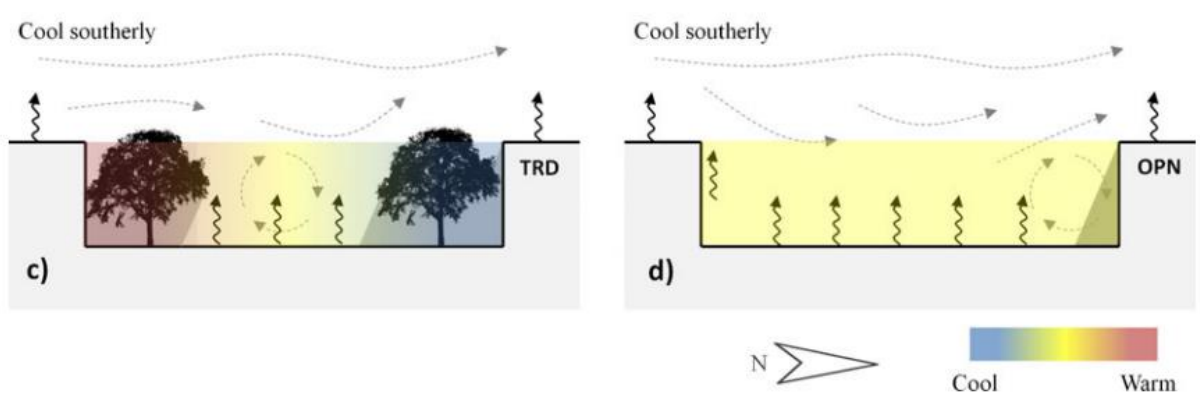

Figura 15 - Diferenças relativas na temperatura média diurna do ar no cânion arborizado (a e c) e cânion sem vegetação ( $b$ e d) em janeiro de 2012, sob as direções do vento norte ( $a$ e b) e sul ( $c$ e d). O sol está ao norte. Fonte: Coutts et al., 2016.

Embora alguns estudos recentes sugiram adotar recursos de geometria urbana para mitigar a Temperatura Radiante Média (TRM) e reduzir o estresse térmico em microclimas urbanos (LAU et al., 2015; TAN; et al., 2016), redesenhar a 
geometria urbana de áreas consolidadas nem sempre é uma alternativa viável. Dessa forma, tomar partido da alternativa de adição de árvores de rua pode ser uma estratégia de projeto mais econômica e com diversos benefícios ao ecossistema urbano, já que o sombreamento proporcionado pelo dossel reduz a TRM durante o dia em condições de céu desobstruído.

\subsection{A VEGETAÇÃO INCORPORADA À EDIFICAÇÃo}

Embora ainda não haja consenso sobre o potencial de telhados e paredes verdes na redução da temperatura do ar, percebe-se que as diferenças nos resultados relatados são em parte devidas aos diferentes cenários examinados, e certamente ao clima local e à referência utilizada. Infelizmente, não se apresentaram ainda estudos de campo capazes de demonstrar uma redução considerável da temperatura do ar que possa ser atribuída diretamente aos telhados verdes (ERELL, 2017).

O comportamento térmico das fachadas verdes difere dos materiais de fachada convencionais, uma vez que a camada de folhagem e a camada de substrato, no caso das paredes vivas, interceptam consideravelmente a radiação solar incidente na fachada de um edifício (DAHANAYAKE; CHOW, 2017). A densidade foliar, a espessura e a textura da folha e o albedo afetam a intercepção da radiação solar; porém, entre esses fatores, é a densidade foliar o fator de maior impacto (LIN; LIN, 2010). Comparadas às coberturas, as fachadas verdes podem representar maiores superfícies em edifícios altos de áreas densamente ocupadas, sendo que a extensão da área potencial para a inserção de vegetação em fachadas, desconsiderando-se a área de janelas, é maior do que a projeção no solo dos edifícios nas cidades. Em comparação com os telhados verdes, existe, portanto, um potencial ainda maior para perceber os benefícios ambientais das superfícies verdes da fachada incrementando a massa foliar e as trocas térmicas úmidas na região onde estão inseridas, contribuindo assim para o balanço térmico nas áreas urbanas (KÖHLER, 2008). Apesar da existência de alguns estudos quantificando o efeito das superfícies 
verdes para o interior dos edifícios (WONG et al., 2009) pouco se sabe sobre os efeitos microclimáticos urbanos das mesmas. Embora essas alternativas não consigam compensar a perda da vegetação no solo, têm se mostrado uma abordagem capaz de diminuir a aridez da malha urbana (GILL et al., 2007).

Como parte dos esforços crescentes para promover as fachadas verdes e elevar Singapura ao status de "City in a Garden", o NParks (National Parks Board) colabora com o BCA (Building and Construction Authority) e o Department of Building School of Design and Environment National University of Singapore NUS, introduzindo e avaliando diversos sistemas verticais. Com o objetivo de se avaliar a eficácia dos sistemas verticais instalados, a manutenção necessária e os benefícios que este tipo de instalação traz aos edifícios e ao meio ambiente em climas tropicais, desenvolveu-se uma pesquisa que inclui oito sistemas, construídos sobre paredes de concreto armado, medindo $6 \mathrm{~m} \times 4 \mathrm{~m}$ (altura $\mathrm{x}$ largura), com monitoramento do isolamento térmico e acústico e do efeito do sombreamento das espécies, entre outros (WONG et al., 2010).

Um dos objetivos do experimento foi determinar a redução de temperatura externa próxima aos sistemas, utilizando-se de termômetros, localizados a $15 \mathrm{~cm}, 30 \mathrm{~cm}$ e $60 \mathrm{~cm}$ das superfícies verticais (Figura 16 e Figura 17), uma sem vegetação, e outros dois sistemas vegetais de instalação Support ${ }^{14}$ e Carrier ${ }^{15}$. No caso estudado em Singapura, como esperado, a diferença de temperatura mais significativa foi identificada nos dispositivos situados a $15 \mathrm{~cm}$ da superfície, tendo sido alcançada uma redução na temperatura do ar de cerca de $3^{\circ} \mathrm{C}$, comparando-se os sistemas Carrier e a superfície sem vegetação. Essa diferença foi reduzida à medida que se afastaram os sensores da superfície, nos sensores localizados a $60 \mathrm{~cm}$ a diferença na temperatura do ar entre as superfícies estudadas foi insignificante (WONG et al., 2010).

\footnotetext{
${ }^{14}$ Sistemas nos quais plantas escaladoras ou arbustos suspensos crescem utilizando-se de estruturas de apoio

${ }^{15}$ Sistemas executados em paineis ou feltros geotêxteis, que podem também ser pré-cultivados e posteriormente fixados em estruturas de suporte verticais.
} 


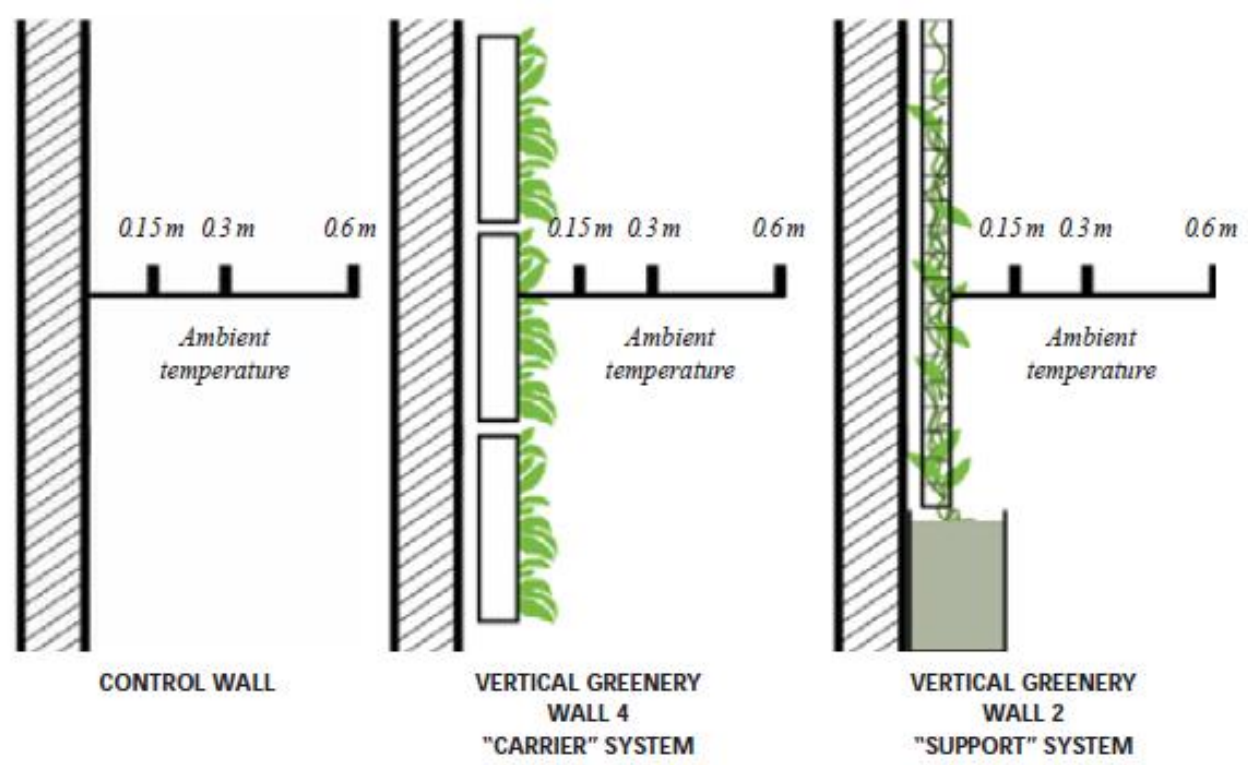

Figura 16: Desenho do experimento com sensores para medição da temperatura do ar próxima às paredes verdes. FONTE: WONG, N.H. Handbook on Green Walls in Singapore, Singapore: National Parks Board, 2009 p. 59.

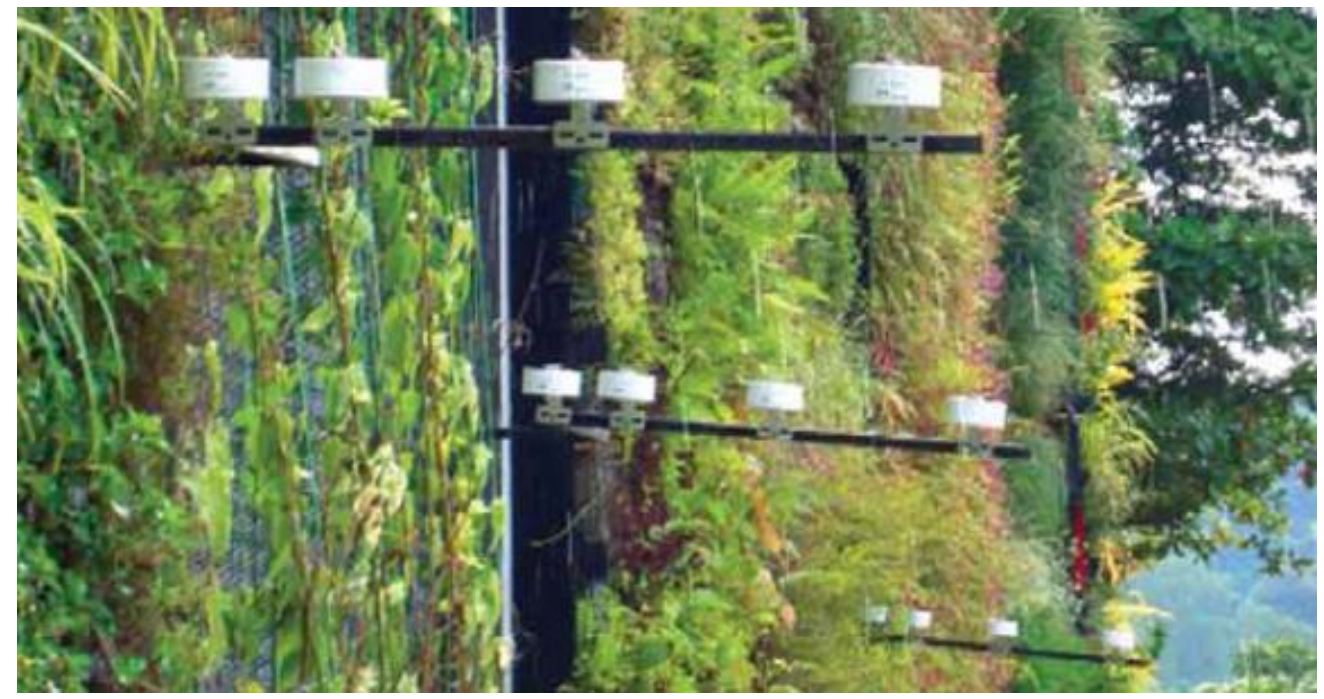

Figura 17: Sensores para medição de temperatura do ar próxima às paredes verdes. FONTE: WONG, N.H. Handbook on Green Walls in Singapore, Singapore: National Parks Board, 2009 p. 59.

Em um estudo realizado em Manchester, em um telhado verde intensivo, dominado por arbustos perenes, verificou-se que o telhado verde analisado foi 
capaz de baixar a temperatura média mensal do ar em até $1,06^{\circ} \mathrm{C}$ em uma altura de $30 \mathrm{~cm}$, quando comparado com um telhado próximo sem telhado verde. $O$ efeito de resfriamento foi mais significativo no período noturno, apresentando uma diferença média de $1,58^{\circ} \mathrm{C}$. O telhado estudado possuía uma parcela sem vegetação, com o substrato exposto; nessa parcela, o efeito de resfriamento foi menor, apresentando temperaturas do ar mais altas durante o dia do que sobre a parcela com vegetação (SPEAK et al., 2013). Em Utrech, Holanda, verificouse a influência dos telhados verdes cobertos de suculentas na temperatura do ar a distâncias de 15 e $30 \mathrm{~cm}$ acima dos telhados verdes. Dois telhados verdes foram comparados com um telhado de cascalho branco convencional, sob diferentes cenários, com diferentes umidades do solo e estresse hídrico extremo. Os resultados demonstraram que, em condições normais, o telhado coberto por vegetação do tipo suculenta apresenta um efeito de aquecimento leve em seu entorno durante o dia, e resfria o entorno imediato durante a noite. Porém, o efeito de resfriamento noturno foi, contudo, menor do que o aquecimento diurno; dessa forma, para o clima de Utrech, e com o tipo de vegetação estudado, o efeito de resfriamento de telhados verdes extensivos ao ar livre, como reivindicado frequentemente na literatura, não foi confirmado nas condições analisadas. Os autores acreditam que os resultados sejam devidos ao tipo de vegetação que compunha o telhado verde, e que plantas do tipo $\mathrm{CAM}^{16}$, mais especificamente suculentas, podem não ser a melhor escolha para um telhado verde, quando visam mitigar as altas temperaturas do ar durante o período diurno. A pesquisa sugere que a disponibilidade de água no substrato desempenha um papel importante no comportamento térmico da cobertura verde, e relata que o efeito da umidade do solo mostrou padrões diferentes para dias nublados e ensolarados (SOLCEROVA et al., 2017).

Diversos benefícios para o interior das edificações podem ser associados às paredes verdes, tais como a melhoria das condições de conforto térmico passivo (WONG et al., 2010), tais como a melhoria no desempenho de sistemas de condicionamento de ar, por reduzirem a temperatura da envoltória e

\footnotetext{
${ }^{16}$ As plantas da CAM (Crassulacean Acid Metabolism) transpiram durante a noite; durante o dia seus estômatos permanecem fechados para evitar a perda de água. Graças a esse mecanismo, as plantas CAM são relativamente resistentes aos períodos de seca, mas por não transpirarem durante o período diurno, não diminuem a temperatura do ar durante o dia.
} 
consequentemente o consumo dos sistemas de climatização; a melhoria da qualidade do ar, como os apresentados em sistemas de biofiltragem, a exemplo dos construídos nas Universidades de Queens e Guelph Humber em Toronto, Ontário (HUM; LAI, 2007), dentre outros. Há um interesse crescente pela implantação deste tipo de envoltória, como parte do processo de recuperação de áreas urbanas, principalmente nos grandes centros, com a verticalização acentuada dos edifícios (MATHEUS et al., 2015).

Uma das vantagens das fachadas verdes é a possibilidade de instalação em edificações novas e também na reabilitação de edifícios pré-existentes, possibilitando a introdução de vegetação em áreas consolidadas, sendo que as paredes verdes podem ser geralmente instaladas em diferentes superfícies e inclinações (curvas, verticais ou horizontais), além de possibilitar a instalação de espécies adaptadas ao clima onde serão inseridas, necessitando de sistemas de irrigação simplificados. Os estudos sobre as contribuições dos recentes sistemas de implantação de paredes verdes na melhoria do desempenho das edificações e as comparações dos impactos destes sistemas com outras soluções utilizadas atualmente poderiam aumentar o interesse por este tipo de envoltória, resultando numa possível redução de custos de implantação proporcionada pela utilização em maior escala (MANSO; CASTRO-GOMES, 2015). Uma camada de vegetação com grande espessura possui propriedades isolantes e de sombreamento das envoltórias, diminuindo o aquecimento das edificações em climas quentes através da diminuição da transferência de calor entre a envoltória do edifício e o seu interior. A evapotranspiração cria um microclima intermediário entre a parede verde e a envoltória da edificação, especialmente em climas quentes (WOOD et al., 2014). Já as paredes vivas, com substrato, se apresentam eficientes na redução das temperaturas internas da edificação devido à capacidade de absorção de calor pelo substrato utilizado e à vegetação escolhida (WONG et al., 2010), evidenciando o potencial de inércia térmica dos jardins verticais com substrato em fachadas para países de clima tropical, contribuindo para a redução ou mesmo não utilização de equipamentos de climatização e consequente economia de energia (SAFIKHANI et al., 2014). 
Comparando-se paredes protegidas por vegetação e paredes desprotegidas, observa-se que nos períodos de maior incidência de radiação solar nos ambientes externos, a presença da vegetação reduz as temperaturas do ar e da superfície quando comparadas às paredes desprovidas deste tipo de proteção (PÉREZ et al., 2011). A temperatura radiante média do ar adjacente às paredes verdes é reduzida em cerca de $3^{\circ} \mathrm{C}$, e a temperatura de superfície a cerca de $6,3^{\circ} \mathrm{C}$, quando comparadas às paredes sem vegetação, segundo estudo experimental realizado em paredes em tijolos construídas no campus da University of Reading, Reino Unido (CAMERON et al., 2014).

As taxas de transpiração e as temperaturas de superfície de paredes verdes revestidas por espécies escaladoras e paredes sem vegetação foram observadas em estudo realizado na cidade de Berlim, Alemanha, onde temperatura do ar, umidade relativa do ar e radiação de onda curta recebida foram medidas. Embora não tenha sido detectado efeito de resfriamento da temperatura do ar no cânion, o efeito no edifício foi claramente detectado, onde a temperatura superficial das paredes externas com vegetação foi até $15,5^{\circ} \mathrm{C}$ menor do que a das paredes sem vegetação, mas os efeitos de resfriamento observados dependiam principalmente do sombreamento, sendo pouco influenciados pela transpiração (HOELSCHER et al., 2016).

Outra possibilidade de utilização das paredes verdes como redutor da temperatura do ar é através do resfriamento evaporativo, quando a estrutura é instalada em parede interna com passagem do fluxo de ar através do substrato ocorrendo de maneira similar ao que acontece em um sistema refrigerador evaporativo direto, onde a conversão de calor sensível no ar em calor latente ocorre com a passagem do ar através de um substrato úmido saturado. Embora as paredes verdes apresentem uma eficácia de apenas 11\% quando comparados aos climatizadores evaporativos comerciais (DAVIS et al., 2015), foi observada uma capacidade de arrefecimento de aproximadamente $2^{\circ} \mathrm{C}$ na temperatura do ar com a instalação de um sistema de grande porte na Faculdade de Arquitetura, Design e Artes da Universidade Católica do Equador, sugerindo que as paredes verdes podem ser utilizadas como um sistema complementar, representando uma redução do consumo de energia para arrefecimento, se o 
jardim estivesse ligado em série a um sistema de ar condicionado convencional (DAVIS et al., 2016).

Paredes verdes podem ter bons resultados também no inverno, principalmente no período noturno, mantendo elevadas em cerca de $3^{\circ} \mathrm{C}$ as temperaturas internas dos ambientes nos horários mais críticos, quando comparadas a paredes na mesma orientação e sem vegetação, reduzindo a demanda de energia para aquecimento. A pesquisa experimental foi realizada durante dois invernos utilizando-se modelos físicos de pequena escala replicados para simular a perda de calor de uma estrutura construída e investigar as propriedades de isolamento das plantas durante o inverno, sugerindo que as paredes verdes possam oferecer características semelhantes a produtos comerciais de isolamento (CAMERON et al., 2015).

Para climas brasileiros, foram desenvolvidos estudos experimentais em três sistemas verdes, compreendendo um estudo de caso com cobertura verde realizado na cidade de Atibaia, SP, um estudo comparativo com parede viva e um estudo comparativo com parede verde, ambos localizados na cidade de Campinas, SP, todos com medições comparativas entre superfícies expostas e protegidas pelo verde, analisando-se as variáveis temperatura e umidade do ar, temperatura de globo negro, velocidade do ar e temperaturas superficiais. $\mathrm{Na}$ cobertura verde, observou-se um atraso térmico de $2 \mathrm{~h}$, comparado à cobertura com telha cerâmica no período do verão, e uma redução de até $9^{\circ} \mathrm{C}$ em sua temperatura superficial interna. As paredes verdes demonstraram um aumento significativo da inércia térmica da envoltória, apresentando diferenças de temperatura superficial de até $33^{\circ} \mathrm{C}$ durante o dia, e $3^{\circ} \mathrm{C}$ à noite, com um atraso térmico de até $2 \mathrm{~h}$. $\mathrm{O}$ estudo concluiu que a presença do verde na envoltória dos edifícios possui a capacidade de amenizar em diferentes escalas os extremos de temperatura observados em regiões de clima tropical e subtropical, deslocando os picos de temperatura superficial interna para horários mais amenos do dia (MATHEUS et al., 2015). Os autores concluem que paredes verdes aumentam a inércia térmica das envoltórias estudadas, tendendo a estabilizar a temperatura superficial dentro de determinado intervalo de temperatura $\left(23-27^{\circ} \mathrm{C}\right)$. 


\subsection{MODELOS PARA ESTUDO DO IMPACTO DA VEGETAÇÃO NO MICROCLIMA URBANO E NO DESEMPENHO TÉRMICO DOS EDIFÍCIOS}

A simulação computacional tem se mostrado uma tendência internacional como recurso para avaliação dos efeitos da vegetação nos microclimas urbanos, com a utilização de diversos modelos computacionais, tais como o modelo SOLWEIG ${ }^{17}$, que foi utilizado em simulação realizada para Adelaide, na Austrália. Em geral, segundo os autores, uma solução para aumentar a provisão de sombra proporcionada por árvores, em lugares onde estratégias de melhoria na geometria da construção não podem ser adotadas ou em áreas onde a exposição dos pedestres é alta, deve-se adotar configurações onde as árvores estejam organizadas em grupos, sempre que possível, de forma a maximizar o potencial de sombreamento durante o dia e permitir a troca convectiva nas superfícies durante a noite (THOM et al., 2016).

Modelos matemáticos desenvolvidos para simulação dos efeitos da vegetação em tetos verdes foram validados por um experimento realizado na Welsh School of Architecture, em Cardiff, durante o verão de 2004, e posteriormente foram implementados no Energy Plus ${ }^{18}$ (ALEXANDRI et al., 2007). Através do EnergyPlus, foram explorados os efeitos do sombreamento, isolamento térmico e evapotranspiração nas paredes verdes, com estudos experimentais desenvolvidos para a cidade de Hong Kong. Demostrando convergência de resultados entre a simulação e os estudos experimentais utilizados, o estudo chega a apresentar uma redução de até $26^{\circ} \mathrm{C}$ na temperatura de superfície e $3 \%$ de redução no consumo anual de energia para resfriamento da edificação no verão. Entretanto, durante o período de inverno, observou-se um aumento na demanda por aquecimento da edificação. Apesar disso, os autores estimam que a economia de energia proporcionada pelas paredes verdes durante o verão é capaz de compensar o aumento da demanda de energia para aquecimento no

\footnotetext{
17 Solar and Long Wave Environmental Irradiance Geometry. Disponível em < http://urbanclimate.net/umep/SOLWEIG > Acesso em janeiro de 2017.

${ }_{18}$ Energy Plus engineering reference. United States Department of Energy. Disponível em: < http://apps1.eere.energy.gov/buildings/energyplus/?utm source=EnergyPlus\&utm medium=red irect\&utm campaign=EnergyPlus\%2Bredirect\%2B1 > acesso em 23 de agosto, 2016.
} 
inverno e ainda produzir um saldo de energia (DAHANAYAKE; CHOW, 2017). Outro modelo chamado "Vegetated Urban Canopy Model" - VUCM (LEE; PARK, 2008), que considera a presença e os efeitos da vegetação nos cálculos radiativos, energéticos e dinâmicos, obteve bons resultados quando comparados a medições de campo realizadas em Vancouver e Marseille. VUCM é um modelo de dossel urbano desenvolvido para a mesoescala meteorológica e modelagem ambiental; sua geometria urbana é composta por volumetrias simples e homogêneas das edificações caracterizada pela relação altura/largura do cânion, e a vegetação é caracterizada pela proporção do perfil e densidade foliares. Cinco superfícies de troca de energia (telhado, parede, pavimento, vegetação e tipo de solo) são consideradas no modelo e as relações de conservação de energia são aplicadas a cada componente.

O TEB-Veg, uma versão com vegetação para o "Town Energy Bugdet” (TEB) (MASSON, 2000), foi desenvolvido com o objetivo de melhorar a representação de áreas verdes urbanas no sistema de modelagem de superfícies terrestres ${ }^{19}$, baseado em cálculos de radiação para um cânion urbano, com a inserção da vegetação. As trocas superficiais entre vegetação e atmosfera são calculadas considerando-se a radiação "real" de ondas curtas e longas recebidas pelas áreas verdes bem como as condições microclimáticas (temperatura, umidade e vento) dentro do cânion, e não somente as trocas realizadas no topo do dossel. As versões do TEB são confrontadas com dados experimentais extraídos de um estudo de campo realizado em Israel, em 2007 (LEMONSU et al., 2012).

Modelos matemáticos simplificados para paredes verdes considerando a resistência térmica para avaliar os efeitos das orientações das fachadas, densidade foliar, a insolação na parede estudada e o impacto proporcionado pela vegetação na absorção do calor também têm sido desenvolvidos (KONTOLEON; EUMORFOPOULOU, 2010).

\footnotetext{
${ }^{19}$ SURFEX (SURFace EXTernalisee, em francês) é o sistema de modelagem da superfície terrestre externalizada (Salgado e Moigne, 2010; Masson et al., 2010) desenvolvido no MeteoFrance.
} 
Outro modelo térmico para estudo de superfícies verdes é o SOLENEmicroclima 20 ; trata-se de um software dedicado à simulação microclimática urbana, implementando um modelo térmico capaz de representar diversos tipos de fachadas verdes, testado através de resultados experimentais realizados em amostras de paredes verdes isoladas. As comparações com os resultados da simulação destacaram fenômenos mais sensíveis e parâmetros do modelo, expondo as limitações desta abordagem simplificada. A simulação foi incapaz de solucionar algumas lacunas sobre questões relativas ao balanço hídrico e o cálculo da evapotranspiração devido aos dados experimentais terem se mostrado insuficientes, sendo que os autores ressaltam ainda a necessidade de medições mais precisas para validação do cálculo da evapotranspiração (MALYS et al., 2014).

Um modelo desenvolvido por Susorova et al. (2013), inicialmente testado para uma edificação educacional em Chicago durante o verão, conseguiu reproduzir os processos físicos e térmicos em uma parede externa coberta de vegetação, incluindo a transmissão da radiação solar através da camada de vegetação, a troca radiativa infravermelha entre a fachada e o céu, a fachada e o solo, a fachada e a camada de vegetação, a convecção da fachada para a própria fachada, evapotranspiração da camada da planta, armazenamento de calor no material da fachada e condução de calor através da fachada. Esse modelo foi validado com resultados de um experimento de medição realizado em um edifício existente no campus do Instituto de Tecnologia de Illinois. O experimento demonstrou que uma camada de vegetação em uma fachada pode efetivamente reduzir as temperaturas externas da superfície das fachadas, as flutuações diárias de temperatura no interior da edificação, os gradientes de temperatura na parede externa e, como resultado, o fluxo de calor através da parede externa, particularmente em dias de céu claro. Uma análise de sensibilidade mostrou que os parâmetros meteorológicos mais eficazes incluem a radiação solar, a velocidade do vento, a umidade relativa e a temperatura do ar externa, por ordem

20 SOLENE-Microclimat é um modelo de simulação numérica para o microclima urbano. Desenvolvido no CRENAU, "Laboratoire de l'école d'architecture de Nantes", permite questionar questões do planejamento urbano e suas repercussões sobre questões relativas à ilha de calor urbano, conforto ambiental térmico, consumo de energia do edifício, entre outros. Disponível em: $<$ http://solenemc.hypotheses.org/> Acesso: fevereiro 2018. 
de importância. A análise também mostrou que as camadas de plantas com folhagem densa (altos índices de área foliar) e com folhas paralelas à parede (altos coeficientes de atenuação) são provavelmente as mais bem-sucedidas na redução das temperaturas da superfície da fachada e do fluxo de calor através das fachadas. Em dias quentes e ensolarados, uma camada verde em uma fachada de tijolos foi estimada, com as configurações apresentadas na Figura 18 para reduzir a temperatura superficial externa entre 0,7 e $13,1^{\circ} \mathrm{C}$, reduzir 0 fluxo de calor através da parede externa entre 2 e $33 \mathrm{~W} / \mathrm{m}^{2}$, dependendo principalmente da orientação da parede, do índice de área foliar e do coeficiente de atenuação de radiação.

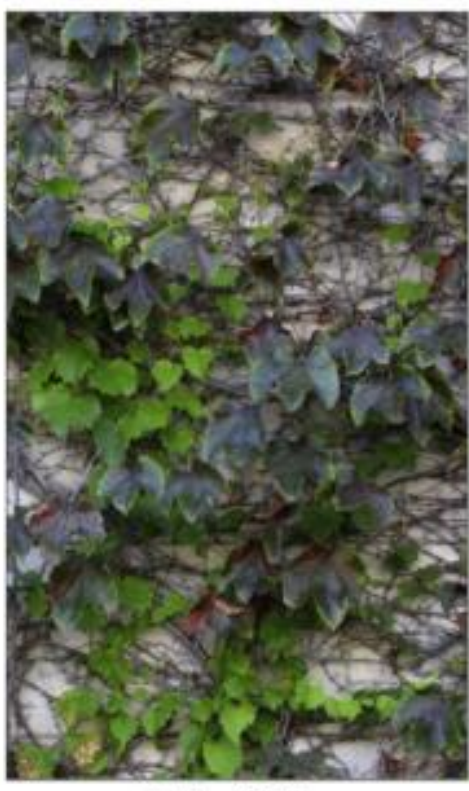

$\mathrm{LAI} \sim 0.25$

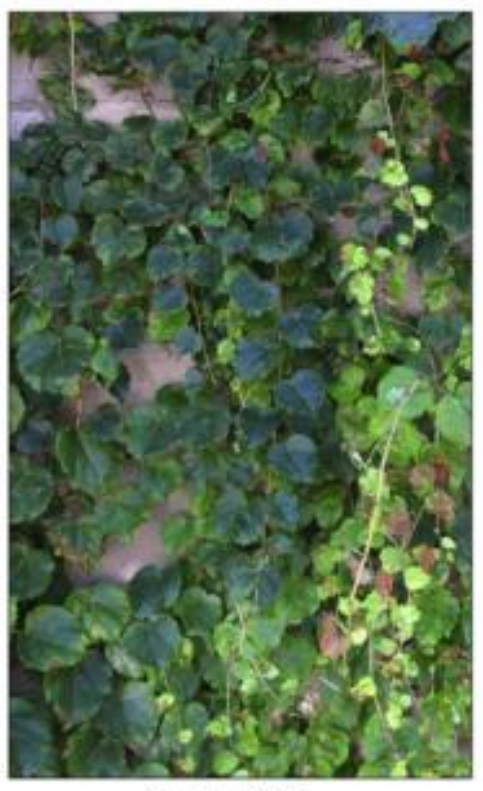

LAI $\sim 0.75$

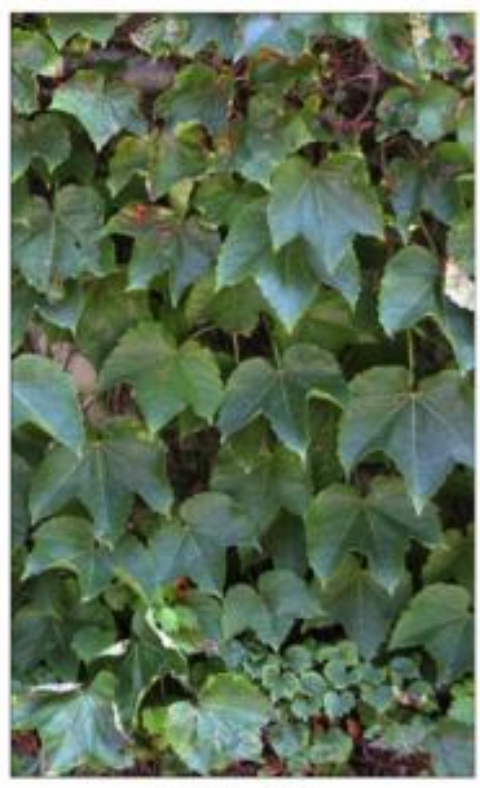

LAI $\sim 1.5$

Figura 18 - Camadas de vegetação com diferentes índices de área foliar, utilizadas no estudo de Susorova et al., 2013.

O "Screening Tool for Estate Environment Evaluation"21 (STEVE) se apresenta como um plugin para o SketchUp 22 ; é uma ferramenta analítica, com a finalidade de gerar mapas de temperatura e perfis que ajudem a prever a temperatura do ar nas áreas urbanas. Trata-se de um modelo empírico, baseado em análises de regressão múltipla, especificamente validado para as condições climáticas de Singapura, a partir de um ponto de vista arquitetônico e de planejamento urbano.

\footnotetext{
${ }^{21}$ http://enterprise.nus.edu.sg. Acesso em fevereiro, 2017.

22 Software para a criação de modelos em 3D. Disponível em < https://www.sketchup.com/ > Acesso em janeiro 2018.
} 
STEVE é capaz de calcular as temperaturas mínimas, médias e máximas para um ponto de interesse de acordo com a situação existente e uma previsão futura. Quando utilizado juntamente com o sistema de informação geográfica (GIS ${ }^{23}$ ), mapas de temperatura do ar podem der desenvolvidos e seus pontos críticos podem ser identificados (WONG; JUSUF, 2008; JUSUF; WONG, 2009).

O ENVI-met é um modelo tridimensional prognóstico de alta resolução para simulação do microclima urbano. Através de seus fundamentos físicos baseados nos princípios da mecânica dos fluidos, da termodinâmica e das leis da física atmosférica, é capaz de considerar tridimensionalmente nos cálculos: turbulência, temperatura e umidade do ar, fluxos de radiação e dispersão de poluentes (BRUSE, 1999). Uma das características únicas do modelo computacional ENVI-met é a modelagem detalhada da vegetação, permitindo com sua alta resolução espacial a simulação da fotossíntese, levando em conta a radiação solar local, a temperatura do ar, a umidade, a velocidade do vento, a concentração de $\mathrm{CO}_{2}$ e muitos outros parâmetros (BRUSE, 2004).

O ENVI-met permite modelar a vegetação de duas maneiras. Plantas que possuem apenas uma estrutura vertical simples, como grama ou culturas, são modeladas como as chamadas "plantas simples". A densidade da área foliar $\mathrm{DAF}^{24}$ de plantas simples no ENVI-met é representada por 10 camadas na atmosfera, enquanto as raízes consistem em 10 camadas de densidade de área radicular (DAR) no modelo de solo. Plantas com um dossel mais complexo, como árvores, são representadas por grupos de células considerando sua densidade de área foliar, proporcionando uma forma tridimensional para a planta; estas plantas estão carregando sua própria geometria tridimensional, são chamadas "3D-plants" e são controladas por um módulo do programa chamado "Albero" (SIMON, 2016).

Para paredes verdes, a modelagem da vegetação é feita em 1D, uma vez que a ferramenta Albero é indicada para modelagem 3D de árvores, que necessitam de modelagem mais elaborada, com a definição de copa e tronco,

\footnotetext{
${ }^{23}$ ESRI@ArcGIS Desktop. Disponível em < https://www.esri.com> acesso em janeiro, 2017. ${ }^{24} \mathrm{~A}$ densidade de área foliar - DAF relaciona a área total de um dos lados da folha pelo volume da área geométrica da copa $\left(\mathrm{m}^{2} / \mathrm{m}^{3}\right)$ (LALIC; MIHAILOVIC, 2004).
} 
diferentemente das paredes verdes que se mostram mais homogêneas, com as folhas iniciando próximas do nível do solo.

O modelo micrometeorológico ENVI-met foi utilizado para o desenvolvimento de experimentos numéricos envolvendo cânions urbanos e árvores de diferentes proporções, diferentes índices de área foliar, diferentes densidades de área foliar e diferentes alturas do tronco sob diferentes condições de vento para a cidade de Hong Kong. Nesse estudo, os dados meteorológicos de entrada do modelo foram configurados considerando-se o dia 1 de agosto de 2015, com temperatura mínima de $26,9^{\circ} \mathrm{C}$ e máxima de $32,2^{\circ} \mathrm{C}$, umidade relativa variando entre $70 \%$ e 82\%. Utilizando-se o índice Temperatura Equivalente Percebida - TEP (Monteiro e Alucci, 2011), caracterizou-se o conforto térmico no cânion. Os resultados mostraram uma variação da TEP com árvores de diferentes distribuições verticais e DAF, ainda que com Índices de Área Foliar - IAF $^{25}$ semelhante. Quanto maior a área coberta pelas árvores, maior é o conforto térmico, sendo que a magnitude dessa variação depende do padrão de plantio das árvores. Verificou-se também que a condição de vento oblíquo forte "sem árvores" era mais eficiente na melhora do conforto térmico do que na situação onde as árvores estavam sujeitas à ação de vento calmo e perpendicular, reiterando a importância da ventilação na obtenção de um ambiente termicamente confortável (MORAKINYO; LAM, 2016). Embora o cenário simulado com a presença de vegetação tenha proporcionado uma redução na TEP, sob a influência da ventilação, a vegetação ainda se apresenta como uma possibilidade mais confiável, uma vez que não se pode controlar a direção dos ventos em áreas urbanas.

A associação de diferentes modelos para suprir eventuais deficiências e viabilizar determinados estudos também se mostra como alternativa possível. 0 acoplamento do modelo computacional ENVI-met com o modelo Virtual Environment by IES ${ }^{26}$ (IES-VE) para verificação do desempenho energético dos edifícios possibilitou uma abordagem interdisciplinar para medir e modelar as mudanças no microclima devidas à inserção de áreas verdes e explorar as suas

\footnotetext{
25 Índice de Área Foliar definida como "metade da área de interceptação total (não projetada) por unidade de área de superfície do solo" (Chen e Black, 1992).

${ }^{26}$ Disponível em < https://www.iesve.com/>. Acesso em janeiro 2017.
} 
implicações nas demandas de energia em Manchester, Reino Unido. No cenário com adição de 5\% de árvores adultas ao estudo de caso urbano, a combinação de modelagem microclimática e análise de dados estimou uma redução máxima da temperatura do ar de aproximadamente $1^{\circ} \mathrm{C}$ nas condições de pico da llha de Calor Urbana e reduções de velocidade de vento de até 1,0 m/s. Estes resultados foram utilizados para alterar os arquivos meteorológicos na modelagem energética de edifícios, que estimou uma redução de 2,7\% na energia necessária para resfriamento no mês julho, durante o versão, devido à redução do aquecimento externo nas horas de pico, proporcionado pela inserção de oito árvores adicionais que resultaram no sombreamento de um edifício de três andares, sugerindo que é possível se atingir uma economia de energia de cerca de $4,8 \%$ em um período de três dias nas condições mais críticas simuladas (SKELHORN et al., 2016).

\subsection{LACUNAS DE PESQUISA NO TEMA}

Mesmo com as pesquisas apresentadas neste trabalho sobre os impactos das fachadas verdes no microclima urbano, ainda existe pouco material sobre o assunto, sendo que, no Brasil, pesquisas sobre o tema em Arquitetura e Urbanismo podem ser encontradas principalmente na Universidade de São Paulo (USP), na Universidade Estadual de Campinas (UNICAMP) e na Universidade Federal de Minas Gerais (UFMG). Diversos pesquisadores internacionais também afirmam ser necessário o desenvolvimento de outros trabalhos para que se possa conhecer todos os benefícios das diferentes configurações de sistemas de instalação de paredes verdes disponíveis, considerando-se os tipos de substrato utilizado, a forma de irrigação e os efeitos da variação na espessura da camada de ar entre a vegetação e a parede (HUNTER et al., 2014; CHAROENKIT; YIEMWATTANA, 2016). A maior parte dos trabalhos realizados sobre o tema estão concentrados na Europa e na Ásia, onde $70 \%$ das análises são feitas através de modelos computacionais e somente os $30 \%$ restantes são estudos experimentais; destes, apenas cerca de $10 \%$ se referem a estudos de caso reais, fortalecendo a relevância do tema para a 
pesquisa (COMA et al., 2014). Outra deficiência é a pouca quantidade de estudos que analisem em profundidade os efeitos da inércia térmica ligados ao substrato em paredes verdes, sugerindo ainda que este é um aspecto importante a se considerar em pesquisas futuras (BROWN et al., 2016).

O modelo computacional ENVI-met está em constante aperfeiçoamento, podendo não ser ainda a ferramenta mais adequada para a investigação de todas as questões relativas ao microclima urbano. Os pesquisadores que apenas estejam interessados em um elemento específico do microclima urbano podem eventualmente encontrar outro modelo que forneça os resultados desejados mais rapidamente e, possivelmente, ainda com mais precisão, como, por exemplo, se o interesse estiver apenas no comportamento do vento induzido em torno das edificações, pode-se facilmente obter resultados mais rápidos e com uma maior resolução espacial utilizando-se um software de dinâmica de fluidos computacional, Computer Fluid Dynamics - CFD (HUTTNER, 2012).

Com relação às simulações com paredes verdes, uma limitação que ainda persiste no ENVI-met até o momento é a impossibilidade de utilização do substrato na posição vertical, pela característica do modelo computacional que considera a alimentação da vegetação feita sempre a partir do solo, impossibilitando a simulação de paredes vivas executadas em paineis, feltros ou suportes modulares, uma vez que, nessas configurações, a alimentação da vegetação deveria vir destes substratos, determinando que esta pesquisa deva considerar necessariamente, até o momento, paredes verdes com a utilização de vegetação do tipo escaladora, para maior fidelidade dos resultados. 


\section{MATERIAL E MÉTODO}

Inicialmente, para contextualização do tema, foram realizados levantamentos considerando-se a inclusão das paredes verdes nas políticas públicas, incluindo os mecanismos de compensação, os indicadores de vegetação e demais instrumentos urbanísticos. Posteriormente foram levantadas e sistematizadas diferentes tecnologias de paredes verdes existentes, além da revisão da literatura considerando estudos de desempenho microclimático de paredes verdes, incluindo estudos experimentais em protótipos, experimentais em casos reais e de simulação.

Em função dos levantamentos realizados nas primeiras etapas deste trabalho, procedeu-se à escolha do modelo mais adequado para o prosseguimento da pesquisa, considerando-se apenas os modelos capazes de realizar a simulação de vegetação incorporada aos edifícios: VUCM (Vegetated Urban Canopy Model), desenvolvido por Lee e Park (2008), que considera a vegetação nos cálculos dinâmicos e energéticos de radiação, porém apresenta geometria simples e homogênea caracterizada apenas pela relação (H/W) do cânion; TEBVeg, que realiza a inserção da vegetação diretamente no cânion, permitindo sombrear as edificações e piso, permitindo a inserção de qualquer configuração de vegetação, porém demandando conhecimentos mais aprofundados dos princípios de micrometeorologia; o modelo computacional Energy-Plus, que permite apenas a configuração de telhados verdes, não aceitando ainda a inserção de paredes verdes; e o modelo computacional ENVI-met, capaz de calcular tridimensionalmente as variáveis de interesse para este trabalho: temperatura e umidade do ar, fluxos de radiação, com modelagem detalhada da vegetação, e resolução a partir de $0.5 \mathrm{~m}$ no espaço. Sendo assim, o ENVI-met foi considerado o modelo computacional mais adequado aos interesses da pesquisa, neste momento, considerando-se a disponibilidade da licença Science $^{27}$ no laboratório onde se desenvolve esta pesquisa e a experiência anterior do grupo em estágios no laboratório desenvolvedor do modelo na

27 Licença do ENVI-met Science V 4.2, com vigência até novembro de 2018, adquirida com recurso FAPESP 2016/01204-7, reserva técnica BEPE, do pós-doutorado da Dra. Paula Shinzato. 
Johannes Gutenberg-Universität, Mainz, sob a orientação do autor, Prof. Michael Bruse e sua equipe.

A principal limitação que ainda persiste no ENVI-met até o momento é a impossibilidade de utilização do substrato na posição vertical, pela característica do modelo computacional que considera a alimentação da vegetação feita sempre a partir do solo, impossibilitando a simulação de paredes vivas executadas em paineis, feltros ou suportes modulares. Nessas configurações, a alimentação da vegetação deveria vir destes substratos, fato que acabou determinando que esta pesquisa deva considerar necessariamente, até o momento, paredes verdes com a utilização de vegetação do tipo escaladora, para maior fidelidade dos resultados.

Em função do modelo adotado, considerando-se suas restrições e recursos, e tendo em vista os testes de sensibilidade pretendidos em função de parâmetros da vegetação e da umidade do solo, o trabalho incluiu, de início, um método dedutivo, de caráter exploratório, por meio do registro de dados da vegetação e do monitoramento de alguns dados microclimáticos em fachadas verdes. Com relação à vegetação, a densidade foliar é um dado essencial de entrada para a parametrização da vegetação do modelo, e as variáveis microlimáticas medidas dão uma ordem de grandeza a ser comparada com os dados de saída do modelo, nos testes de sensibilidade.

O trabalho de campo foi realizado com o apoio da equipe do LABAUT (SHINZATO, 2014; DUARTE, 2015) e utilizando-se os equipamentos existentes no laboratório. Em um edifício residencial com parede verde na região metropolitana de São Paulo, foi feita uma medição in loco das variáveis da vegetação: temperatura de superfície da folha $\left({ }^{\circ} \mathrm{C}\right)$ e densidade de área foliar DAF $\left(\mathrm{m}^{2} / \mathrm{m}^{3}\right)$ da vegetação escaladora, além da temperatura de superfície da parede de alvenaria $\left({ }^{\circ} \mathrm{C}\right)$, além da temperatura do $\operatorname{ar}\left({ }^{\circ} \mathrm{C}\right)$, umidade relativa do ar $(\%)$, temperatura de globo $\left({ }^{\circ} \mathrm{C}\right)$ e temperatura de solo $\left({ }^{\circ} \mathrm{C}\right)$.

O modelo utiliza como parâmetro a DAF, distribuída em 10 camadas de folhas; desta forma foi considerada nas simulações a relação entre IAF e DAF proposta por Lalic e Mihailovic (2004), utilizando-se os valores de $0,5 \mathrm{~m}^{2} / \mathrm{m}^{2}, 1,0 \mathrm{~m}^{2} / \mathrm{m}^{2} \mathrm{e}$ $2,0 \mathrm{~m}^{2} / \mathrm{m}^{2}$. 
Na etapa seguinte o método é indutivo, pela comparação entre os resultados de diferentes cenários paramétricos simulados com a vegetação incorporada na fachada dos edifícios, variando-se os parâmetros de IAF e umidade do solo, visando observar como o modelo computacional ENVI-met reage às variações propostas, na intenção de concluir se o modelo é realmente adequado para a realização de estudos mais aprofundados, justificando o investimento em pesquisas futuras que visem à calibração entre dados microclimáticos medidos em campo e simulados para paredes verdes.

\subsection{O MODELO NUMÉRICO DE SIMULAÇÃO ENVI-met E 0 PROCESSO DE MODELAGEM DE PAREDES VERDES}

Para o presente trabalho, pelos recursos e restrições levantados anteriormente, e dada a disponibilidade de licença do modelo computacional ENVI-met V4.2 Science optou-se pela utilização do modelo ENVI-met, que é um sistema de modelagem microclimática de alta resolução, concebido para simular as interações entre solo, vegetação e atmosfera em microescala. Com seus fundamentos físicos que se baseiam nos princípios da mecânica dos fluidos, termodinâmica e as leis da física atmosférica, é capaz de calcular tridimensionalmente as variáveis: turbulência, temperatura e umidade do ar, fluxos de radiação e a dispersão de poluentes (BRUSE; THÖNNESSEN; RADTKE, 1999).

Uma das características únicas do modelo computacional ENVI-met é a modelagem detalhada da vegetação (SIMON, 2016). Com a sua elevada resolução espacial, o ENVI-met permite a simulação das taxas individuais de fotossíntese, considerando a radiação solar local, temperatura e umidade do ar, velocidade do vento, concentração de $\mathrm{CO}_{2}$ e muitos outros parâmetros (BRUSE, 2004). O modelo já é bastante reconhecido para avaliação do microclima urbano. A qualidade do modelo é constantemente avaliada por diversos pesquisadores, além da equipe responsável pelo seu desenvolvimento (NIKOLOVA et al., 2011; YANG et al., 2012, WONG, 2012 et al.), entre outros. 
Na versão atual28, as plantas não são mais tratadas como células soltas com um determinado IAF, mas são considerados objetos agregados ou organismos que reagem às condições ambientais. Com sua alta resolução, o modelo computacional ENVI-met é capaz de modelar as trocas de $\mathrm{CO}_{2}$ e vapor de água no nível foliar usando uma adaptação do modelo de estômatos de Jacobs (BRUSE, 2004). O modelo $\mathrm{A}-g_{s}$ é usado para estimar o comportamento estomático de folhas únicas considerando-se as condições microclimáticas da planta como um todo. O principal pressuposto do modelo é que as plantas operem a condutância estomática de forma a maximizar o ganho de $\mathrm{CO}_{2}$ enquanto a perda de água associada é minimizada (JACOBS, 1994).

Com resolução a partir de $0.5 \mathrm{~m}$ no espaço e um período típico de 24 a 48 horas com intervalo de 1 a 5 segundos no tempo, seu layout é apresentado nos eixos x, y e z, e sua área de simulação é estruturada em grades, com informações referentes à camada limite (boundary layer) a 2500m; o modelo apresenta área de aninhamento (borda do modelo), necessária à adequação dos parâmetros do modelo em função do entorno. Apresenta ainda Banco de dados de plantas - $1 D$ e $3 D$ Albero e banco de dados de solos e materiais.

Após as medições de campo, de caráter exploratório, realizadas para este trabalho, e em função das variações nos dados de densidade de área foliar observados, optou-se pela realização de sete simulações paramétricas do cenário modelado, com a utilização de vegetação do tipo escaladora nas quatro faces de um edifício isolado no centro do lote, mantendo-se constantes o sistema de fachada e o edifício, variando-se o IAF e a umidade do solo.

O modelo ENVI-met V4.2 considera no balanço de energia os fluxos de radiação de onda curta e onda longa, o sombreamento das estruturas, o comportamento térmico dos edifícios, considerando separadamente cada fachada e sua orientação, a taxa de evapotranspiração e o fluxo de calor sensível das áreas verdes, incluindo a simulação completa de todos os parâmetros físicos da planta, as trocas de calor e umidade no solo e o balanço hídrico da vegetação, a

\footnotetext{
${ }^{28}$ A principal fonte de informação foi o website do Modelo ENVI-met. (BRUSE, 2018). Disponível em < http://www.model.envi-met.com/ > acesso em janeiro de 2018.
} 
dispersão de gases e partículas, assim como o cálculo de alguns índices biometeorológicos.

Na versão atual, os autores disponibilizam um modelo para cálculo dos principais fatores relacionados à vegetação: transpiração, evaporação, fluxo de calor sensível, fluxos turbulentos de calor e vapor; resistência dos estômatos, balanço energético da folha e balanço de água do sistema solo-vegetação. O modelo considera não apenas o efeito de sombreamento das árvores, mas também o processo fisiológico de fotossíntese e abertura dos estômatos. Em relação à vegetação, este modelo determina a temperatura média nas folhas por meio de cálculo do balanço térmico que considera a condição climática e fisiológica da planta. O cálculo do fluxo de radiação inclui sombreamento, absorção e reemissão da radiação por outras partes da planta.

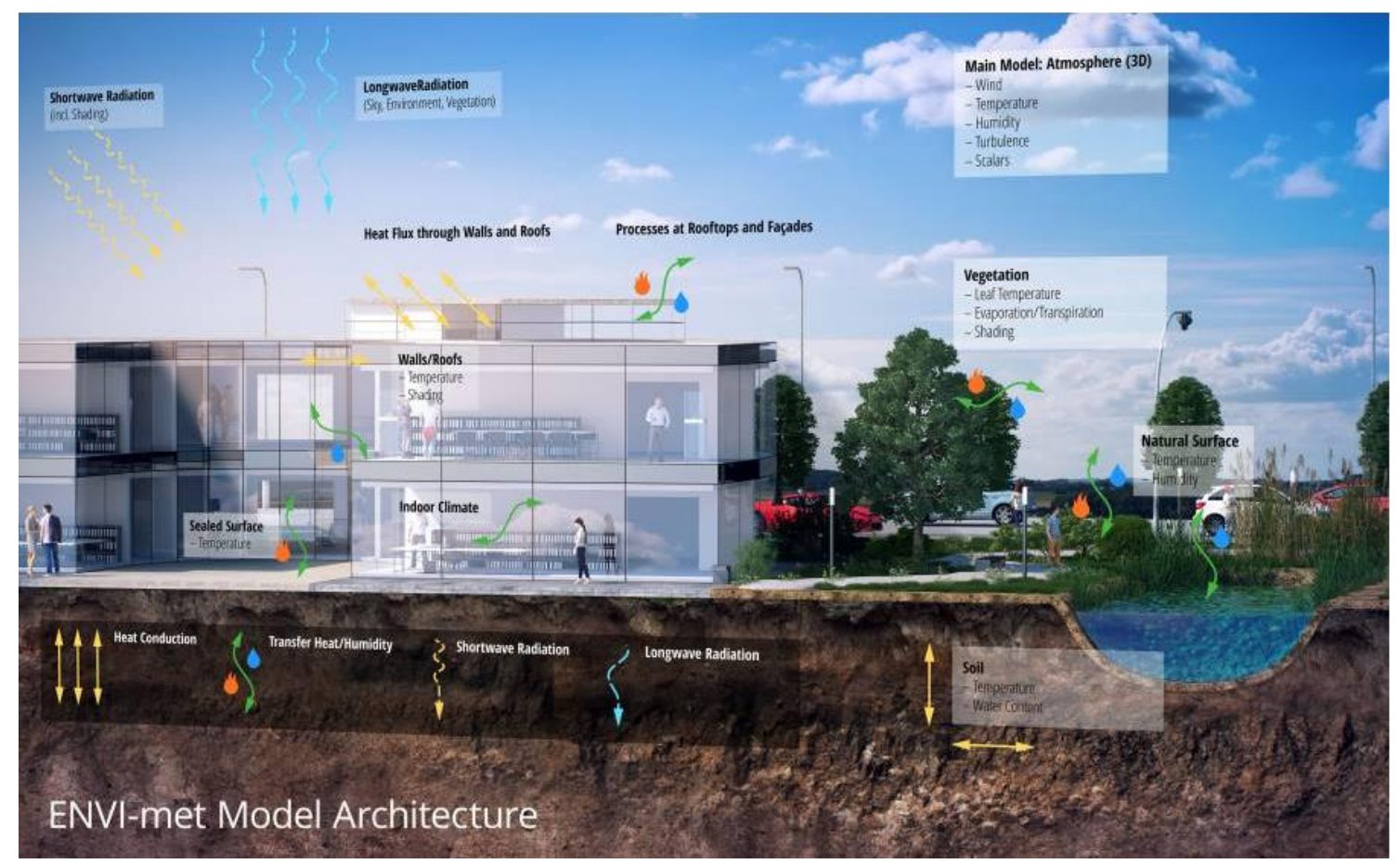

Figura 19: Variáveis consideradas no balanço de energia do modelo ENVI-met. Disponível em < http://www.model.envi-met.com > Acesso em outubro de 2016. 


\subsubsection{Layout do modelo computacional ENVI-met}

A Figura 20 mostra uma representação gráfica do modelo principal que é concebido em 3D, com dois eixos horizontais ( $X$ e $Y$ ), e um eixo vertical $(Z)$. Dentro deste modelo principal os elementos que representam a área de interesse devem ser inseridos. Por se tratar de um modelo numérico, a área de interesse deve ser representada por células na grade ortogonal, sendo a célula o elemento de maior resolução. O tamanho determinado para cada célula deve levar em consideração que quanto menor a célula, mais células serão necessárias para a modelagem de uma determinada área, ou seja, uma área de 100×100m pode

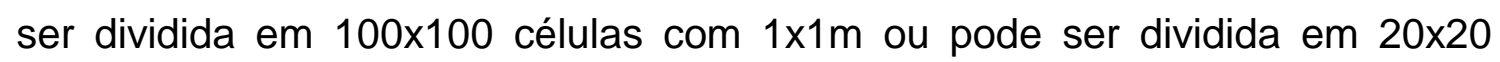
células com $5 \times 5 \mathrm{~m}$, sendo que a definição da solução adotada depende da área que se pretende simular e do nível de precisão necessária. No modelo computacional, a menor dimensão da grade ortogonal possível é de 0,50m $x$ 0,50m; para este trabalho, foi adotada a dimensão de 1,00m $\times 1,00 \mathrm{~m}$ porque, embora, teoricamente o modelo aceite a configuração da grade como $0,50 \mathrm{~m} x$ 0,50m, quando configurado com a grade mínima, o modelo gera automaticamente a nova área com o valor de 1,00m x 1,00m.

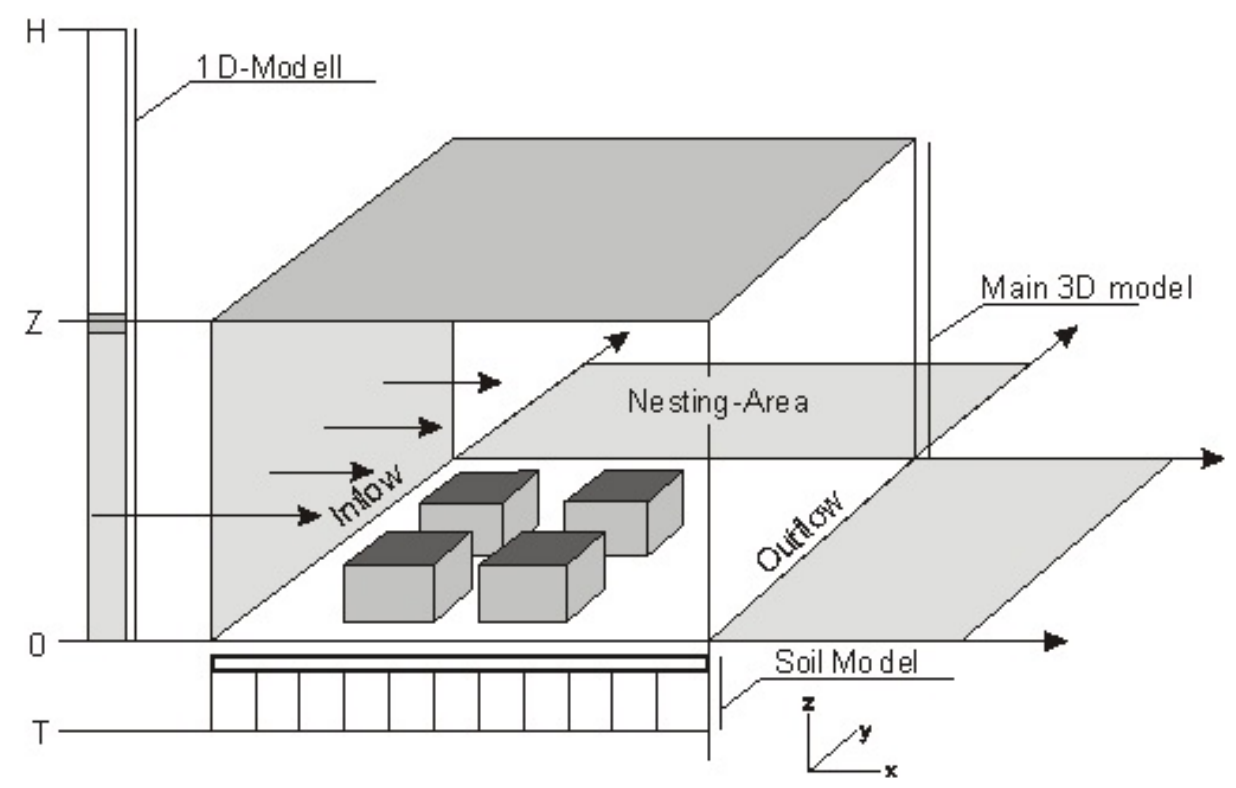

Figura 20: Layout básico modelo computacional ENVI-met.

Disponível em <http://www.model.envi-met.com > acesso em outubro 2016. 
Como a memória numérica de armazenamento disponível é um recurso limitado, várias estratégias são utilizadas pelo modelo ENVI-met para simular toda a área necessária, utilizando o menor número de células possível; para isso, o modelo conta ainda com o recurso de um modelo adicional 1D.

Para uma simulação precisa dos processos da camada limite se faz necessário estender o modelo a uma altura limite mínima de 2.500m. Por não ser possível estender a área de simulação tridimensionalmente até essa altura, o modelo adicional 1D assume o cálculo a partir do limite especificado pelo usuário, e também fornece perfis verticais de todas as variáveis para o limite de entrada do modelo em 3D.

Outro conceito de atendimento ao máximo de espaço horizontal sem a sobrecarga de células é a utilização da grade de aninhamento, que consiste em um conjunto de células que envolvem a área que será efetivamente modelada e simulada, sendo que seu tamanho é variável de acordo com a área estudada.

Para a simulação dos elementos presentes no solo, faz-se necessário o cálculo das transferências térmicas entre a superfície e as camadas mais profundas do solo, sendo que o modelo considera ainda a quantidade de água presente no solo do modelo simulado, informação necessária para estimar a transpiração máxima da vegetação e a quantidade de água disponível na superfície do solo, fator importante no cálculo da sua temperatura superficial.

\subsubsection{Grade Vertical}

A grade vertical necessita de uma alimentação de dados tão precisa quanto a grade horizontal; para modelos $2.5 \mathrm{D}$ a grade vertical é gerada baseada nas configurações do modelo, tais como a altura informada do dossel, permitindo ainda neste modelo a alteração das configurações posteriormente. Já nos modelos 3D a grade é fixa, sendo necessário predefinir a configuração do eixo vertical. 


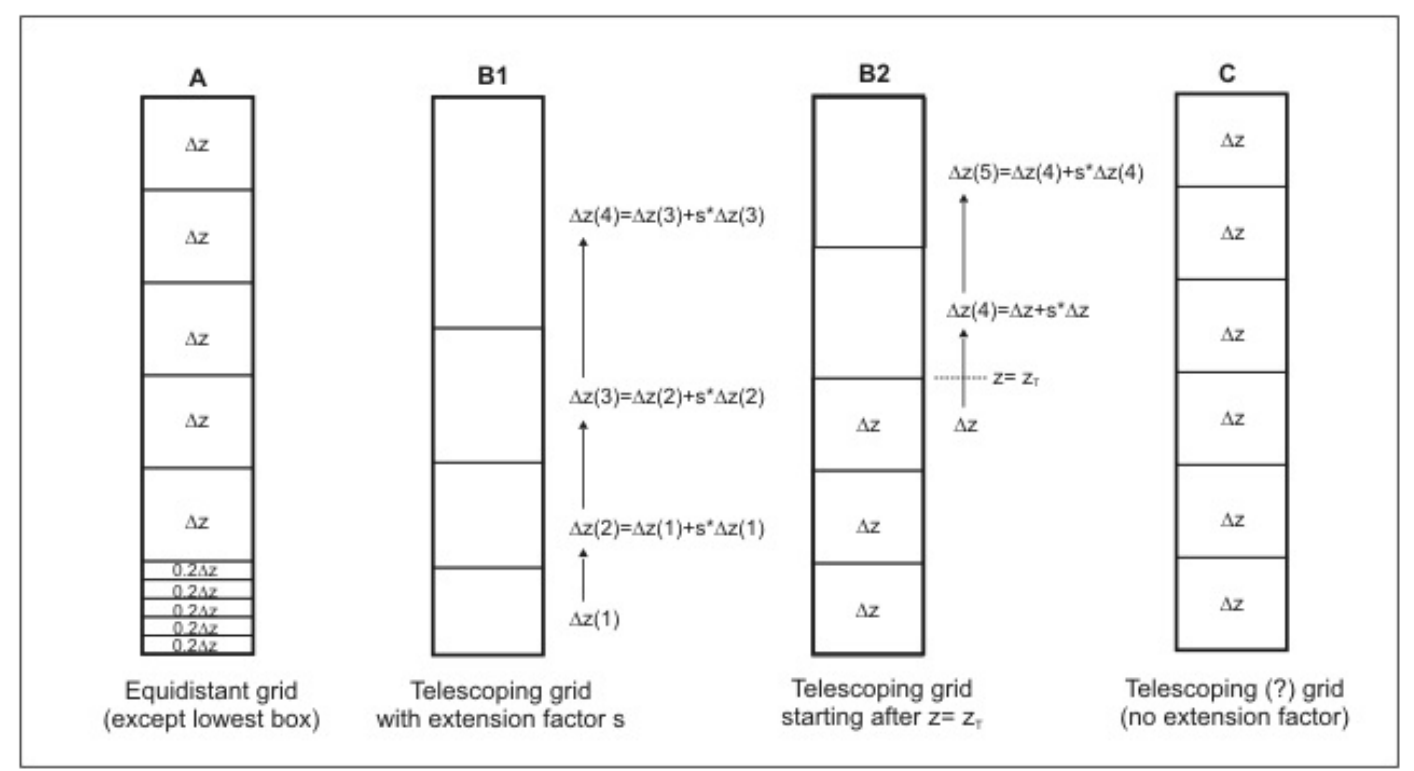

Figura 21: Diferentes conceitos de organização da grade vertical (A) Equidistante (B1) Telescópica (C) Grade telescópica sem fator de extensão. Disponível em <http://www.model.envi-met.com > acesso em outubro de 2016.

Grade Equidistante: tem o mesmo espaçamento entre as camadas, sendo apenas a primeira camada subdividida em cinco subcamadas com $\Delta z s=0.2 \Delta z$. $\mathrm{Na}$ alimentação inicial do arquivo deve-se inserir $\mathrm{o} \Delta \mathbf{z}$ das camadas não divididas; esta grade deve ser utilizada em modelagens de altura limitada e com processos que apresentem quase o mesmo interesse de estudo em todas as alturas.

Grade Telescópica: permite abranger mais altura sem o esgotamento de pontos de grade; deve ser utilizada se o domínio modelo tem objetos altos, como arranha-céus, por exemplo, que devem ser compreendidos nos resultados dos cálculos; porém, os processos que ocorrem nas camadas superiores do modelo são de menor interesse.

$\mathrm{Na}$ alimentação inicial do arquivo deve ser especificado o tamanho da camada menor logo acima da superfície e a percentagem de aumento para a próxima camada (extensão fator $\mathrm{s}$ ). A grade vertical $\Delta z$ de uma camada $k$ pode ser calculada por:

$$
\Delta_{z(k)}=\left[\left(1 \frac{s}{100}\right)\right]^{k-1} \cdot \Delta_{z \text { inicial }}
$$


Onde $s$ é o fator de extensão dado em percentagem e $\Delta_{z \text { inicial }}$ é a altura definida pelo usuário para a primeira camada no caso B1 (Figura 21), podendo ainda ser especificada a altura onde a grade telescópica deve se iniciar $\left(z_{t}\right.$ para o caso B2 da figura 21). Todas as camadas abaixo deste nível serão espaçadas através da constante $\Delta_{z}$ inicial referida a $z_{t}$ e a grade telescópica será iniciada a partir deste ponto, sendo que o aumento máximo é de $20 \%$, pela limitação de altura imposta pelo Modelo 1D.

Grade telescópica sem fator de extensão: para gerar uma grade vertical sem dividir a menor camada em 5 subcamadas, deve-se utilizar a grade telescópica com um fator de extensão $s=0$; alternativamente, pode-se usar o método B2 e definir $z_{t}$ a um nível muito elevado, não atingido pelo modelo.

No modelo $1 \mathrm{D}$ as camadas entre a superfície e a altura do modelo 3D são idênticas. Acima da altura do modelo 3D, o ENVI-Met V4.2 utiliza, no modelo 1D, camadas adicionais para alcançar a altura de $2.500 \mathrm{~m}$ (definida como constante). A espessura dessas camadas é suavemente crescente com a altura, sendo que o fator de crescimento é calculado em relação à altura real do topo do dossel do modelo 3D.

O cálculo dos fluxos de temperatura e umidade no solo é feito apenas ao longo do eixo z. Portanto, o próprio modelo de solo tem de ser chamado de modelo 1D, apesar de sua extensão tridimensional (HUTTNER, 2012).

Para o presente trabalho foi utilizada a grade equidistante, por se tratar de modelagem de edifício de baixa altura $(15 \mathrm{~m})$ e com processos que apresentem quase o mesmo interesse de estudo em todas as alturas.

\subsubsection{Grade de Aninhamento}

A área de aninhamento se faz necessária porque os modelos numéricos, especialmente modelos 3D, como ENVI-met, não funcionam de forma confiável nos seus limites de simulação. Esse problema resulta da impossibilidade de 
cálculo de valores reais além dos limites de simulação, necessitando de uma área para aproximação.

As células da grade de aninhamento não permitem a modelagem sobre as mesmas, sendo criadas apenas na memória interna do modelo, embora seja possível atribuir diferentes perfis de solo para essas áreas de acordo com a necessidade do usuário.

Pela ausência de elementos construídos na grade de aninhamento, a radiação pode ser considerada pelo modelo como atingindo a superfície sem reduções, o que pode ocasionar um excesso de radiação nos cálculos de temperatura de superfície na área de aninhamento, principalmente se os perfis de solo forem superfícies impermeáveis. Para corrigir esse problema o ENVI-met apresenta a possibilidade de utilização de valores médios de radiação, em função dos valores calculados na área modelada.

Neste trabalho não foi utilizada grade de aninhamento, em função das dimensões e localização da edificação no centro do modelo estudado, e pelo conhecimento prévio de que a grade de aninhamento tende a aquecer a temperatura inicial do ar no modelo, efeito indesejável para os testes de sensibilidade pretendidos.

\subsubsection{A altura total do modelo}

Para uma modelagem correta, é necessário definir adequadamente a altura do modelo, considerando-se que a dimensão horizontal é determinada aproximadamente pela dimensão da área de interesse; a altura vertical do modelo é menos óbvia e pode causar grandes erros nos resultados se não for determinada corretamente.

Uma sugestão dos criadores do modelo é que a altura total em metros deve ser pelo menos duas vezes a altura da estrutura mais alta, principalmente se essa estrutura for um edifício, e deve ter, pelo menos, $30 \mathrm{~m}$, no caso de estruturas menores. 
Sendo assim, para o presente trabalho foi utilizada uma grade equidistante com células base de 1,00m de altura e altura total do modelo de 30,00m (Figura 22).

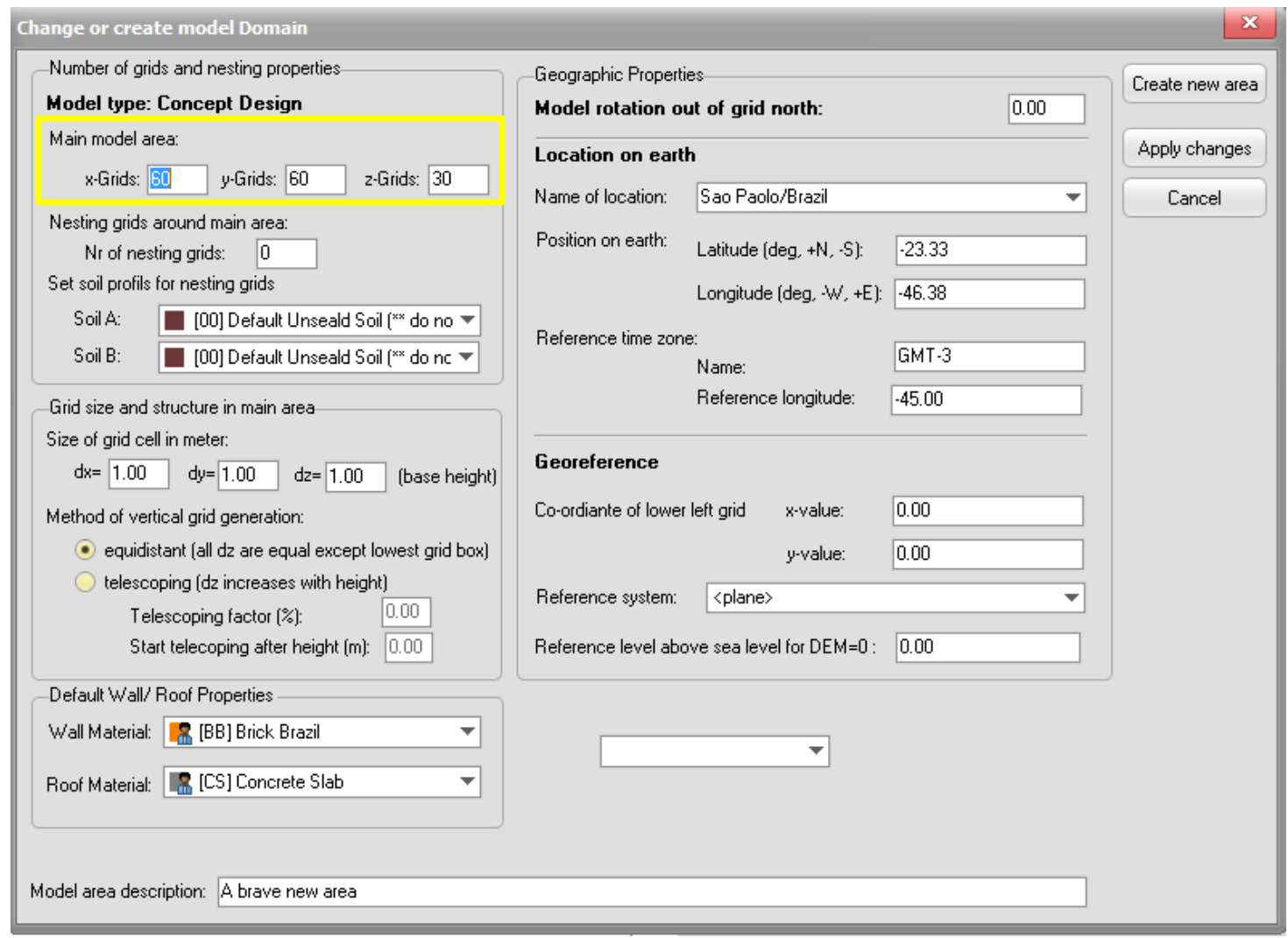

Figura 22 - "Basic settings" utilizados no domínio do modelo simulado.

\subsubsection{Condições de contorno lateral}

As condições de contorno lateral - LBC (Lateral Boundary Conditions) definem a forma como o modelo se comporta em seus limites laterais. A partir da versão 4, os desenvolvedores do modelo (BRUSE, 2016) recomendam usar pelo menos a opção "Full Forcing" para temperatura e umidade, resolvendo quase todos os problemas observados com os limites laterais nas versões anteriores. Três tipos diferentes de condições de contorno lateral podem ser determinados no ENVImet V4.2:

LBC Abertas: Os valores do próximo ponto de grade perto do limite são copiados para o limite para cada ponto temporal. É a condição com o mínimo efeito do contorno para as partes internas do modelo. Para a maioria dos casos, 
este é o LBC recomendado. Mas como a LBC aberta copia os valores das partes internas do modelo para os limites, existe a possibilidade de instabilidade numérica.

LBC Forçadas (ou fechadas): Os valores do modelo unidimensional ou de dados forçados são copiados para o limite, apresentando-se como a condição mais estável, uma vez que o modelo praticamente independente 1D é utilizado para se obter os valores limite de estabilidade do modelo 3D. Por outro lado, o perfil 1D terá um efeito significativo sobre os dados do modelo principal. Se o perfil 1D não é representativo para as condições médias, poderá ocorrer um determinado erro. Utilizando-se a opção "Simple Forcing", a LBC forçada será aplicada para as variáveis temperatura e umidade. Os valores aplicados ao limite do modelo são considerados a partir do perfil previamente determinado. Utilizando-se o modo "Full Forcing", a LBC forçada será aplicada a todas as variáveis, incluindo o vento.

LBC Cíclicas: Os valores à jusante do limite do modelo são copiados para o limite do modelo à montante, e a LBC cíclica assume que as condições médias à montante da área do modelo (que produzem o perfil de entrada) são semelhantes à área do modelo. À medida em que os valores do limite de escoamento são reproduzidos para o limite de entrada, passa a existir a possibilidade de um retorno indesejável no interior do modelo, podendo causar instabilidades numéricas.

É possível escolher as LBCs para as variáveis: temperatura, umidade e turbulência. Para o campo de fluxo, uma LBC aberta será utilizada de forma não forçada ou pela configuração "Simple Forcing". Utilizando-se a opção "Forcing" os LBCs serão, em qualquer caso, "forçados", de modo que seus perfis prédefinidos (temperatura, umidade, vento, etc.) serão reproduzidos no modelo principal.

De forma geral, a escolha de cada LBC depende da situação que será simulada. Para este tranalho, foram realizados alguns testes iniciais utilizando-se o recurso "Full Forcing"; porém, observou-se na análise dois resultados que o "plugin" desenvolvido para utilização em clima tropical necessita de ajustes, tendo apresentado resultados distorcidos. Esse fato determinou que os testes de 
sensibilidade para este trabalho considerassem os resultados obtidos através da configuração "Simple Forcing".

\subsubsection{Receptores}

Os arquivos de saída padrão fornecem os dados relativos ao domínio do modelo completo em duas (arquivos de superfície) ou três dimensões (atmosfera e solo). Todas as vezes que o arquivo é salvo, um novo arquivo de saída é criado.

Estes ficheiros são úteis para as análises da distribuição espacial das diferentes variáveis, mas existem situações nas quais o usuário está interessado no desenvolvimento temporal de variáveis em determinados pontos no interior da área do modelo, como nas situações onde se pretende fazer comparação com medições.

O conceito de receptores permite a coleta de dados de pontos selecionados na área do modelo de maneira compacta, facilitando a busca das informações. Para cada receptor é criado um arquivo instantâneo e um arquivo de séries temporais.

A última versão do ENVI-met 4.2 permite a extração das séries temporais em qualquer célula através do modelo adicional de visualização de resultados chamado Leonardo; desta forma, não foram posicionados receptores neste trabalho, possibilitando a obtenção os dados em qualquer momento, além das séries temporais com os dados da execução completa da simulação.

A descrição do Módulo de Visão Panorâmica e códigos internos do modelo computacional ENVI-met V4.2, encontram-se no Apêndice 1. 


\subsubsection{Vegetação no ENVI-met}

A Figura 23 mostra a representação gráfica da vegetação no ENVI-met, que é derivada de uma estrutura cuboide partindo de um modelo vetorial e de parâmetros como o DAF que determina sua volumetria. Na versão atual do ENVImet as plantas 3D utilizadas para gerar as densidades de área foliar no modelo são consideradas como um organismo.
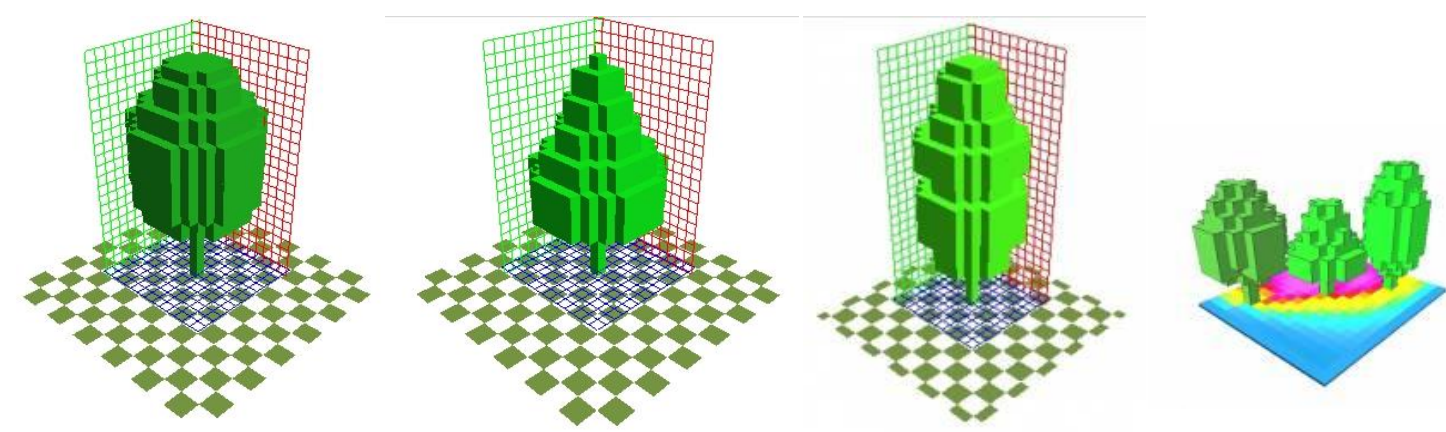

Figura 23 - Representação gráfica da vegetação arbórea no modelo, no módulo Albero do ENVI-met. Disponível em <http://www.model.envi-met.com > acesso em outubro de 2016.

O cálculo da densidade de área foliar (DAF) é obtido por:

$$
\frac{\text { área foliar }\left(m^{2}\right)}{\text { volume de referência }\left(m^{3}\right)}
$$

O ENVI-Met, assim como a maioria dos outros modelos, simplifica o DAF, considerando-o unilateral, significando que apenas um lado da folha é considerado como a área de superfície ativa, o que pode ser justificado pelo fato de que a maioria das plantas tem estômatos em apenas um dos lados da folha, o que normalmente ocorre em sua face posterior. Dessa forma, para as trocas de calor latente pode-se considerar apenas um lado da folha como superfície ativa; também para as trocas de calor sensível, normalmente apenas um lado da folha é exposto ao vento, enquanto que a outra face está a sotavento, o que tende a aproximar de zero o valor do coeficiente de troca nesta face. 
Os perfis de IAF fornecidos originalmente pelo modelo computacional ENVI-met são baseados em poucos perfis de referência. Dessa forma, conhecendo-se a DAF máxima da planta que se deseja simular é possível modelar a planta distribuindo o IAF ao longo da altura, ou conhecendo-se IAF, que corresponde à razão entre a área foliar do dossel e a unidade de superfície projetada no solo, pode-se modelar a planta e verificar se os valores são realistas, somando-se os diferentes níveis de DAF. Entretanto, necessitando-se de valores mais precisos, existem basicamente dois métodos de obtenção: medições in loco e métodos analíticos.

O ENVI-met permite definir qualquer planta, desde uma forração até árvores de grande porte, utilizando o mesmo banco de dados. O banco de dados principal PLANTS.DAT é armazenado na pasta Isys.basedata, sendo que o usuário pode utilizar esse arquivo ou inserir bases de dados que contêm mais definições de plantas.

Esta entrada define se é uma planta de um tipo $\mathrm{C}^{29}$ ou de um tipo $\mathrm{C} 4^{30}$. A maioria das colunas do banco de dados é preenchida com os perfis de DAF (densidade de área foliar) e RAD (densidade da área radicular). Ambos são quantificados em $\mathrm{m}^{2}$ de superfície de folha ou raiz por volume de ar em $\mathrm{m}^{3}$.

Os perfis são normalizados a partir do $\mathrm{z} / \mathrm{H}=0,1$ (DAF 1 e RAD 1) para $\mathrm{z} / \mathrm{H}=$ 1 (DAF 10 e RAD 10) onde $z$ é a altura do DAF ou a entrada RAD e $\mathrm{H}$ é a altura total da planta ou a profundidade da raiz. Assim, são sempre necessárias 10 entradas, independente se a vegetação em questão é a uma forração com 50 centímetros ou uma árvore tropical com dezenas de metros de altura. O perfil será então esticado ou comprimido para o tamanho desejado na célula do modelo.

\footnotetext{
29 Plantas como soja, feijão e todas as árvores que tiveram a fotossíntese estudada até 0 momento, usam a via C3 para a fotossíntese como caminho de carboxilação, recebendo esse nome porque a via tem início com um composto de 3 carbonos.

30 Plantas que desenvolveram um sistema complementar à via C3 chamado de via C4 (cana de açúcar e parte das bromélias). Este sistema permite à folha o armazenamento de ácidos com 4 carbonos antes de estes serem captados pela enzima que inicialmente fixa o gás carbônico na fotossíntese, chamada Rubisco, como um dos grandes problemas das plantas é a perda de água pelos estômatos quando estes estão abertos para permitir a entrada do $\mathrm{CO}_{2}$, o mecanismo $\mathrm{C} 4$, ao aumentar a concentração deste gás nas células da bainha vascular, acaba evitando a perda de água, pois o aproveitamento do CO2 é muito melhor do que em plantas $\mathrm{C} 3$.
} 
$\mathrm{Na}$ versão atual do ENVI-met, todas as interações entre a vegetação e a atmosfera calculadas no nível da folha são agregadas e transferidas para a planta, permitindo uma análise baseada no acesso à água e na vitalidade da planta. Adicionalmente, um modelo de raiz tridimensional foi introduzido, permitindo o cálculo de abastecimento de água para cada organismo (SIMON, 2016).

No processo de evapotranspiração, considera-se a perda associada de água, que ocorre através da evaporação da água de superfície do solo conjuntamente à transpiração estomática e cuticular da planta.

A evapotranspiração está diretamente relacionada à resistência estomática, à disponibilidade de água no solo e à disponibilidade de luz.

Para as simulações com vegetação, o modelo sugere uma entrada padrão para a umidade de solo de 50\%, 60\% e 60\%, para as camadas superficial, intermediária e profunda, pedindo para se evitar valores de umidade no solo abaixo de $10 \%$ para não comprometer os efeitos da evapotranspiração.

Simon (2016) observou em seus estudos com o ENVI-met que a radiação ativa é fundamental para a transpiração da planta. Para replicar diferentes situações, o modelo foi executado em um modo de forçamento completo permitindo a definição de variações diurnas como condições de contorno para os parâmetros meteorológicos medidos: temperatura do ar e umidade, velocidade e direção do vento e radiação (onda curta direta, difusa e de onda longa), para simular com precisão a taxa de transpiração das árvores, a área do modelo e, particularmente, a replicação da geometria da árvore, que provou ser substancial.

O modelo de vegetação do ENVI-met é capaz de capturar não só a magnitude, mas também as variações de curto prazo na transpiração causadas por pequenas mudanças ambientais como a cobertura de nuvens local (SIMON, 2016).

Normalmente as simulações no ENVI-met são executadas em condições de céu claro; no entanto, caso haja necessidade, o usuário pode desejar executar a 
simulação com a suposição de uma cobertura de nuvens, e para esses casos existe a ferramenta "Clouds".

Diferentemente do que acontece com a radiação de ondas curtas, o componente difuso não é atenuado pela vegetação na versão mais recente. A introdução de nuvens no modelo pode elevar as temperaturas quando comparada a uma solução sem nuvens, se uma grande quantidade de vegetação está presente na área de simulação, quando a distribuição de energia é deslocada para o componente difuso.

O módulo Albero foi desenvolvido exclusivamente para a modelagem de vegetação de porte arbóreo, sendo que o banco de dados 3D do ENVI-met não permite, neste módulo, a criação de estruturas simples como grama, arbustos, telhados e paredes verdes; desta forma, a estrutura estudada neste trabalho foi modelada com vegetação em 1D.

\subsubsection{Edição e visualização dos resultados: a ferramenta Leonardo}

O Leonardo é uma ferramenta adicional para edição e visualização dos resultados simulados pelo ENVI-met.

Os arquivos originais do ENVI-met possuem formatos EDT e EDI, sendo possível exportá-los para planilhas de cálculo como as do programa Windows Excel; outra forma de visualização é através do Leonardo, nos formatos 2D e 3D.

O Leonardo realiza uma interface com os arquivos do ENVI-met que permite uma navegação simplificada chamada "DataNavigator". Através desta interface o Leonardo irá interpretar os arquivos no formato EDI e fornecerá uma listagem de variáveis armazenadas, juntamente com o título e a dimensão dos dados de simulação que estarão exibidos na parte inferior da lista; além disso, a camada de vetores apresenta diversas de opções para se gerar a representação do fluxo de vento no domínio modelo. 
A ferramenta "Isoline" fornece uma funcionalidade básica para o desenho de curvas de nível para o mapa. As isolinhas são extraídas como linhas descontínuas, necessitando de um tratamento adicional posterior em software apropriado para este fim, caso haja necessidade de se obter isolinhas em alta resolução.

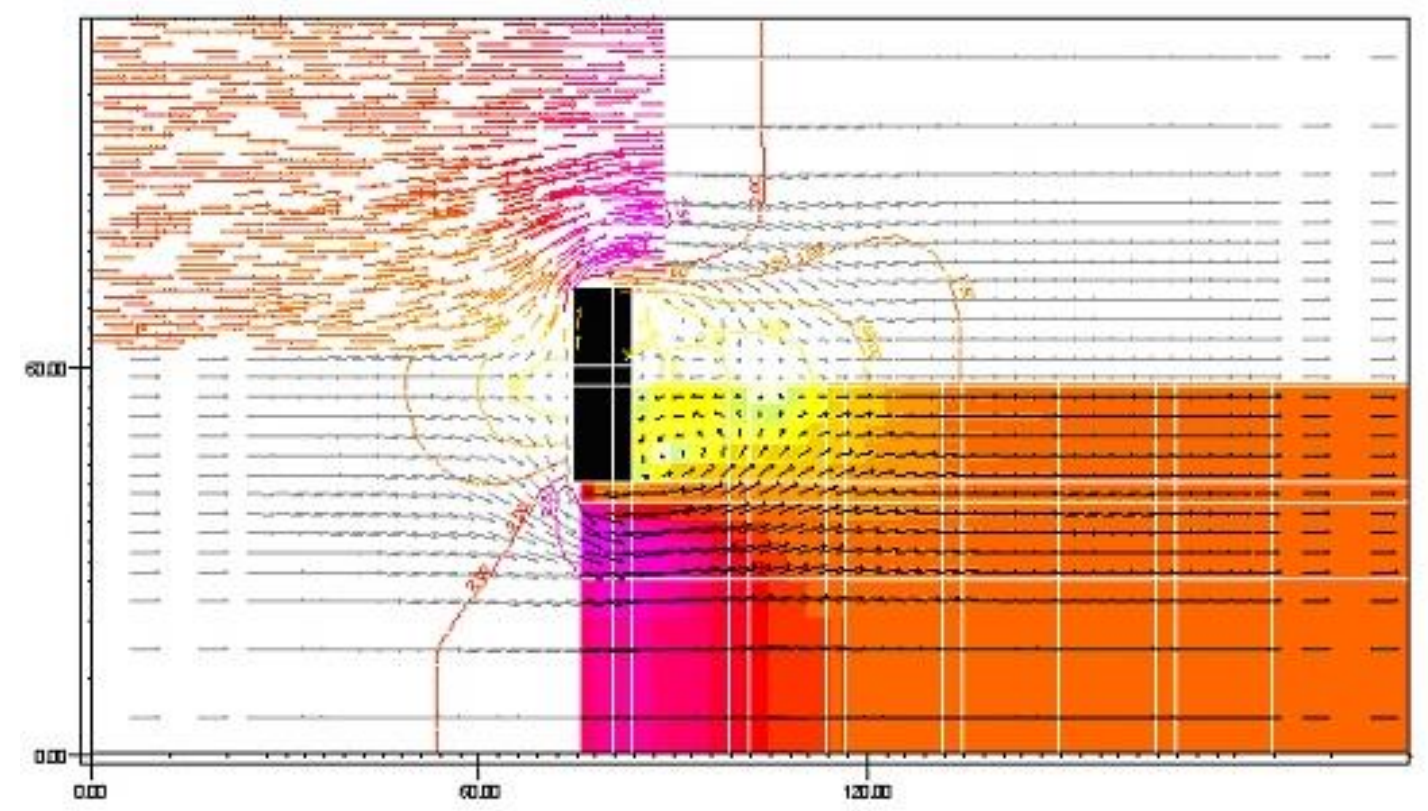

Figura 24 - Modelo típico de visualização de dados na ferramenta Leonardo. Disponível em <http://www.model.envi-met.com/> acesso em outubro 2016. 


\subsection{MEDIÇÕES MICROCLIMÁTICAS}

As medições tiveram o apoio do grupo de pesquisa do LABAUT - Laboratório de Conforto Ambiental e Eficiência Energética da Universidade de São Paulo, tendo sido utilizados Sensores HOBO da Onset, disponíveis no laboratório, posicionados a aproximadamente $0,90 \mathrm{~m}$ de altura do solo no ambiente externo, para a medição das variáveis: temperatura do $\operatorname{ar}\left({ }^{\circ} \mathrm{C}\right)$, umidade relativa do $\operatorname{ar}(\%)$, temperatura de globo $\left({ }^{\circ} \mathrm{C}\right)$, temperatura de superfície $\left({ }^{\circ} \mathrm{C}\right)$ e temperatura de solo $\left({ }^{\circ} \mathrm{C}\right)$, conforme apresentado na Tabela 4 , abaixo:

Tabela 4 - Especificações dos equipamentos utilizados em medição de campo.

\begin{tabular}{|c|c|c|c|c|}
\hline Equipamento & $\begin{array}{l}\text { Faixa de } \\
\text { Medição }\end{array}$ & Acurácia & Localização & Observações \\
\hline $\begin{array}{l}\text { Dattalogger } \\
\text { Hobo Onset } \\
\text { U23-001 }\end{array}$ & -40 a $70^{\circ} \mathrm{C}$ & $\pm 0.2^{\circ} \mathrm{C}$ & Ponto 2 & \\
\hline $\begin{array}{l}\text { Dattalogger } \\
\text { Hobo Onset } \\
\text { U23-004 }\end{array}$ & -40 a $70^{\circ} \mathrm{C}$ & $\pm 0.2^{\circ} \mathrm{C}$ & Ponto 1 & Inserido no globo \\
\hline $\begin{array}{l}\text { Dattalogger } \\
\text { Hobo Onset } \\
\text { TMCx-HD }\end{array}$ & $-40^{\circ}$ a $100^{\circ} \mathrm{C}$ & $\pm 0.2^{\circ} \mathrm{C}$ & Ponto 3 e 4 & $\begin{array}{l}\text { Sensor de temperatura para } \\
\text { água e solo }\end{array}$ \\
\hline $\begin{array}{l}\text { Dattalogger } \\
\text { Hobo U12-012 }\end{array}$ & $-20^{\circ}$ a $70^{\circ} \mathrm{C}$ & $\pm 0.3^{\circ} \mathrm{C}$ & Ponto 5 e 6 & Termopares \\
\hline $\begin{array}{lc}\text { HOBO } & \text { Onset } \\
\text { Pro v2 Loggers }\end{array}$ & $\begin{array}{l}-40^{\circ} \text { to } 70^{\circ} \mathrm{C} \\
0 \text { a } 100 \% \text { UR }\end{array}$ & $\begin{array}{l} \pm 0.2^{\circ} \mathrm{C} \\
\pm 2.5 \%\end{array}$ & Ponto 1 & $\begin{array}{l}\text { Sensor de temperatura e } \\
\text { umidade relativa do ar }\end{array}$ \\
\hline $\begin{array}{lr}\text { Solar } & \text { Radiation } \\
\text { Shield } & \text { Hobo } \\
\text { (RS1) } & \end{array}$ & & & Ponto 1 e 2 & \\
\hline $\begin{array}{l}\text { Câmera } \\
\text { fotográfica } \\
\text { Canon T3i }\end{array}$ & - & - & - & 18.0 megapixels \\
\hline $\begin{array}{l}\text { Lente olho de } \\
\text { peixe Sigma EX } \\
\text { DG Fisheye } \\
8 \mathrm{~mm} 1: 3,5\end{array}$ & - & - & - & Ângulo de visão de 180 graus \\
\hline
\end{tabular}

A escolha do local de medição foi afetada for questões de segurança dos equipamentos, que deveriam estar posicionados no nível do pedestre, em localização protegida de vandalismos.

Inicialmente foram realizados contatos e reuniões com a Secretaria Municipal do Verde e do Meio Ambiente da Prefeitura Municipal de São Paulo na intenção de 
monitorar uma das paredes verdes do Elevado Presidente João Goulart, o Minhocão, no centro de São Paulo. Porém, as medições inicialmente pretendidas foram inviabilizadas por duas razões: pela falta de segurança para os equipamentos na região e também por uma limitação do modelo, com a impossibilidade de simulação de paredes vivas executadas em paineis com 0 substrato na posição vertical no ENVI-met, que considera, até o momento, a absorção de nutrientes apenas a partir do solo. Segundo os autores do modelo, esse módulo está em constante desenvolvimento e deve ser incorporado às próximas versões.

Optou-se, então, pela realização das medições em condomínio residencial na região metropolitana de São Paulo, em paredes verdes com vegetação do tipo escaladora, buscando uma melhor adequação do experimento aos recursos do modelo e à segurança dos equipamentos. Sendo assim, entre os dias 05 e 09 de dezembro de 2016 foram realizadas medições exploratórias das variáveis da vegetação e das variáveis microclimáticas, externas ao edifício nesse local.

\subsubsection{ESCOLHA DOS PONTOS}

As medições foram realizadas em um condomínio residencial na região metropolitana da cidade de São Paulo, na cidade de Taboão da Serra/SP, em frente a um edifício de 25 pavimentos, buscando uma melhor adequação do experimento aos recursos do modelo e à segurança dos equipamentos.

Para simulação de paredes verdes no ENVI-met V4.2 a dimensão mais adequada da grade ortogonal é de $1,00 \mathrm{~m} \times 1,00 \mathrm{~m}$. A parede verde escolhida para a realização das medições apresenta orientação sudeste, conforme Figura 25 , que recebe radiação solar direta apenas no período da manhã no mês de dezembro, quando foram realizadas as medições. A parede verde tem uma espessura de 0,60m, com altura de 2,80m e densidade foliar irregularmente distribuída. A Figura 26 apresenta um esquema com a localização dos pontos de medição, a Figura 27, Figura 28 e Figura 29, apresentam o entorno imediato à edificação. 

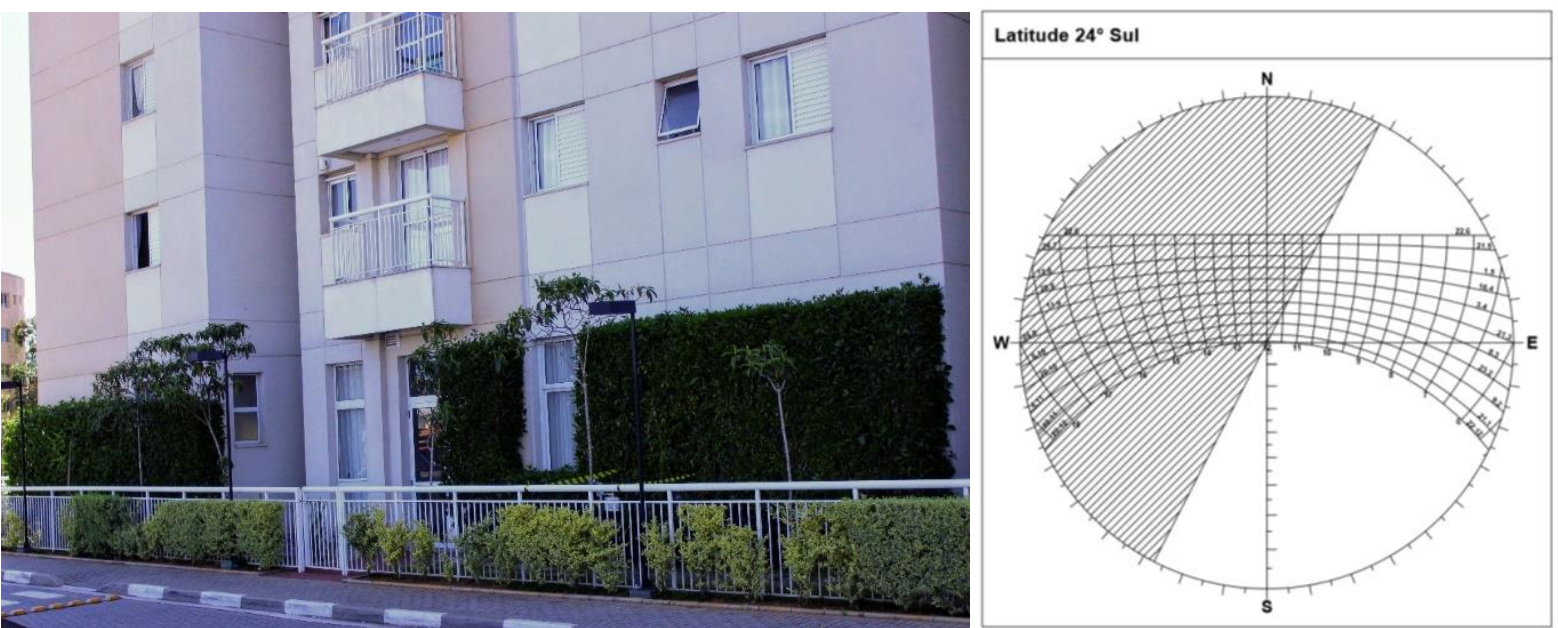

Figura 25 - Vista e orientação solar da fachada estudada

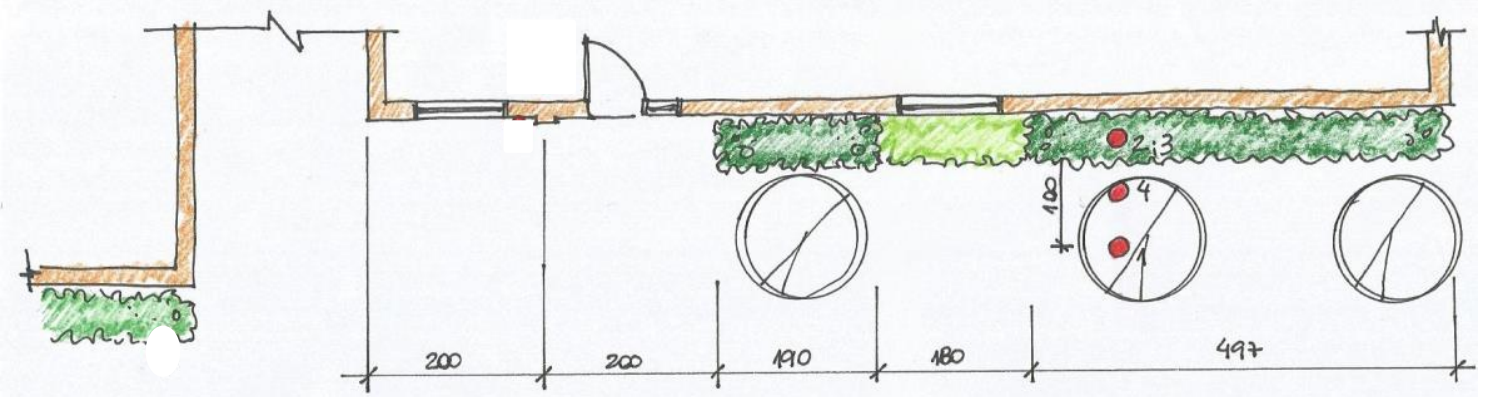

Figura 26 - Localização dos pontos de medição.

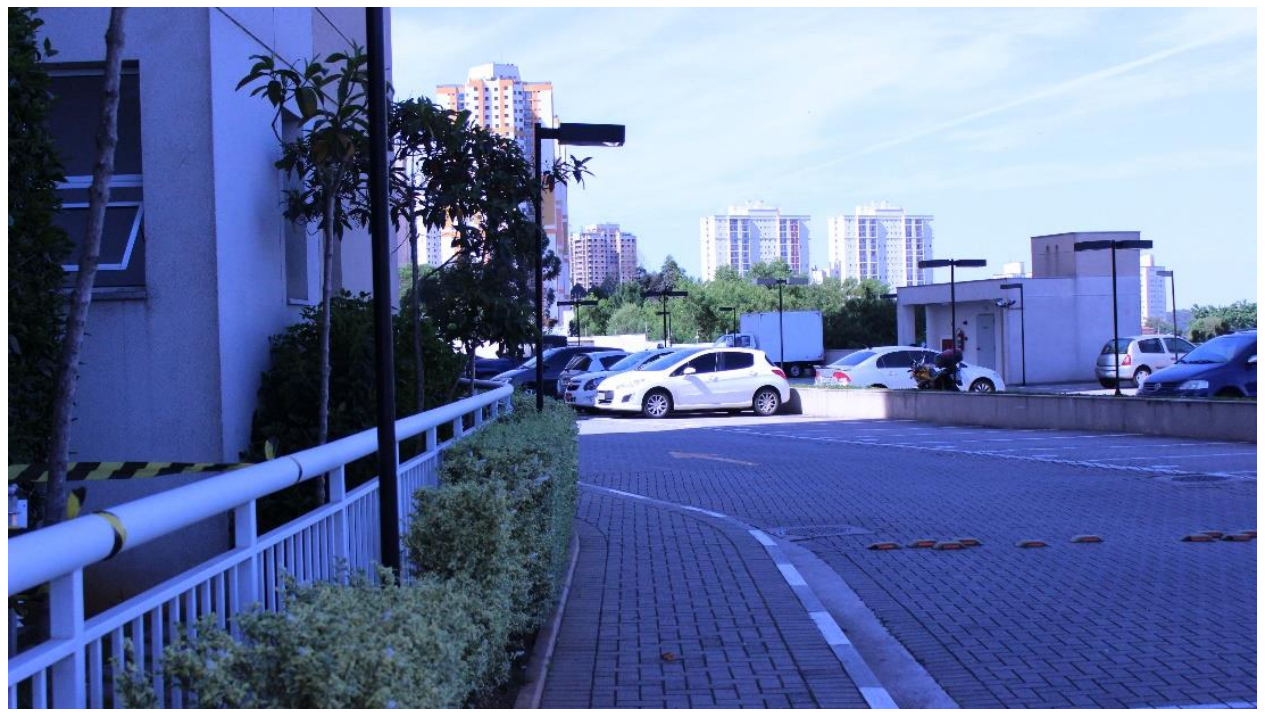

Figura 27 - Entorno da fachada estudada. 


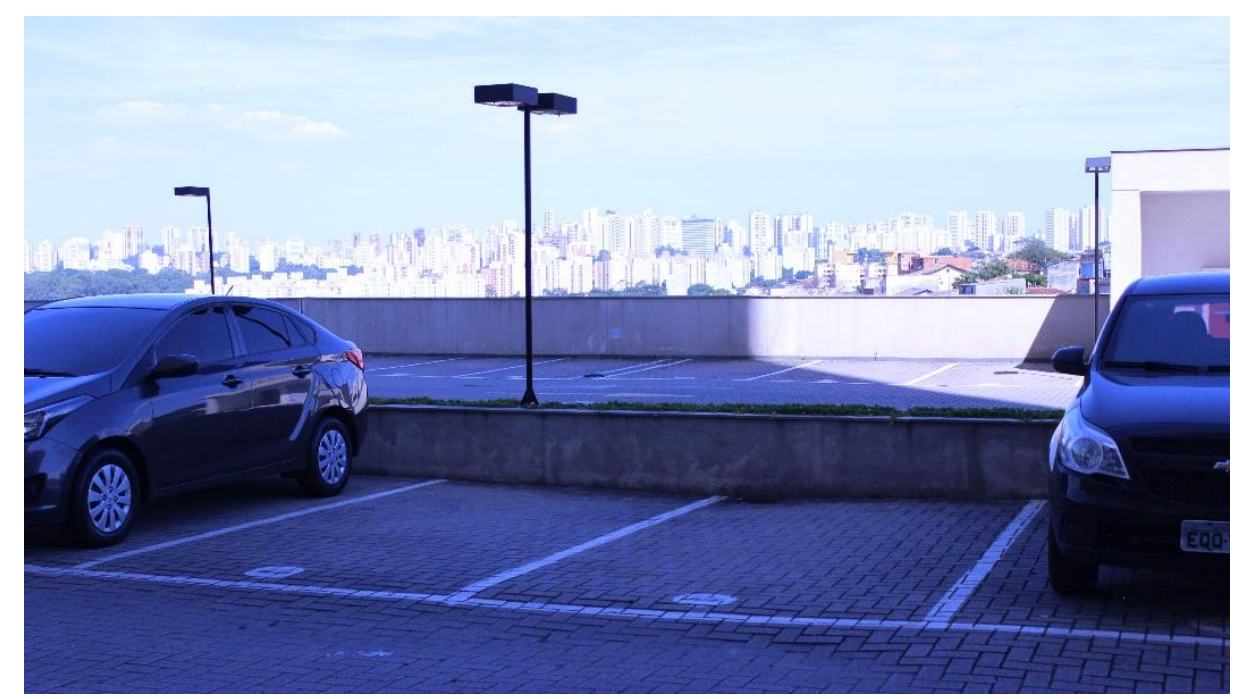

Figura 28 - Entorno da fachada estudada

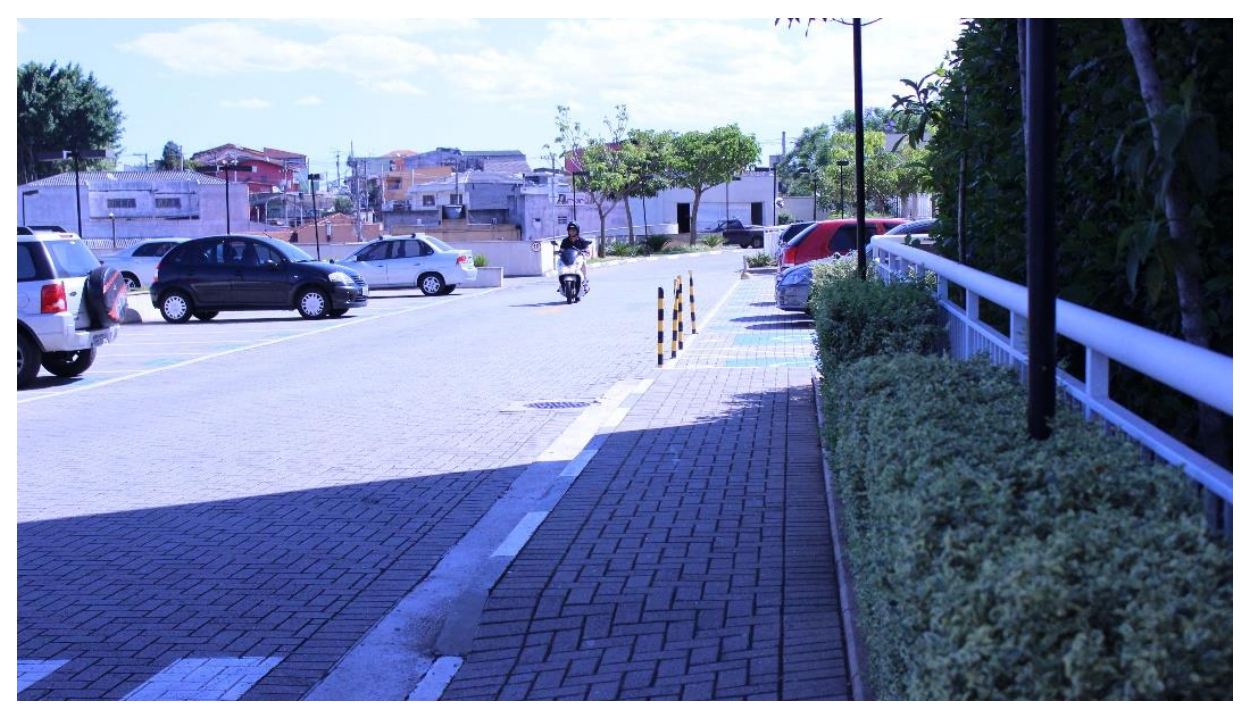

Figura 29 - Entorno da fachada estudada

Ponto 1: A Figura 30 mostra o ponto 1 onde foi posicionado o tripé, distante cerca de $1 \mathrm{~m}$ da parede, com um termo-higrômetro da HOBO Onset com proteção contra a radiação solar direta e difusa para as medições da temperatura do ar $\left({ }^{\circ} \mathrm{C}\right)$ e umidade relativa do ar (\%) e também um globo negro para medição da temperatura de globo $\left({ }^{\circ} \mathrm{C}\right)$. Os sensores foram colocados a $0,90 \mathrm{~m}$ do piso, e a Figura 31 corresponde à visão do céu do ponto 1 , capturada às 8 do primeiro dia de medição. 


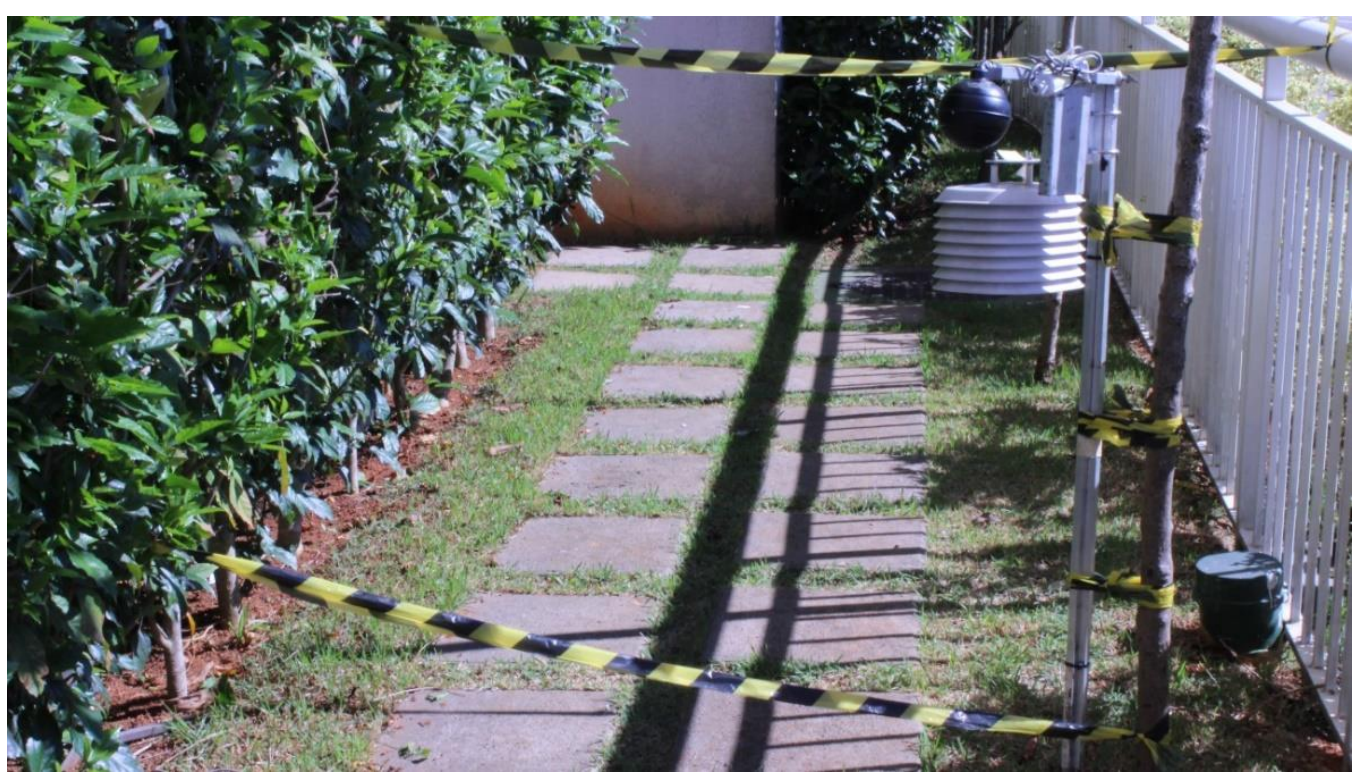

Figura 30 - Localização e posicionamento do ponto 1 de medição.

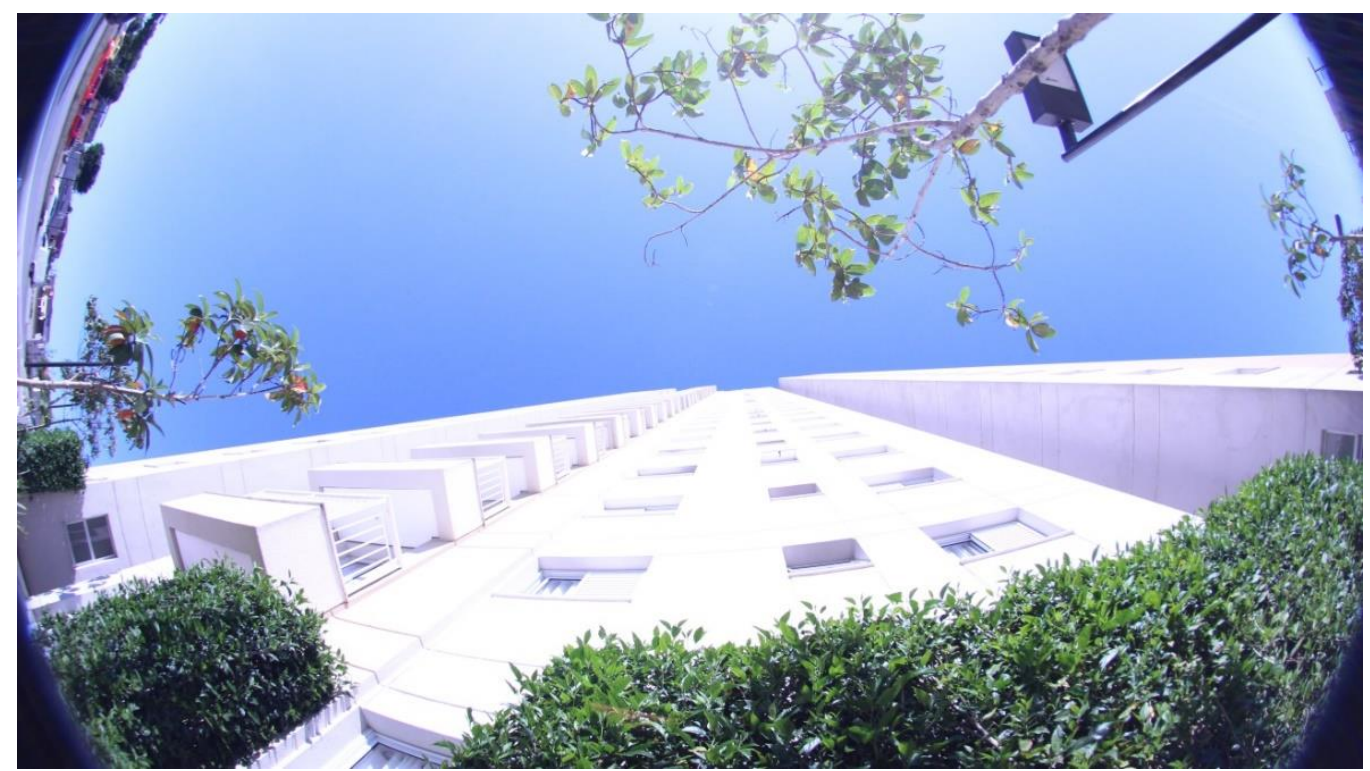

Figura 31 - Foto hemisférica demonstrando a visão de céu no Ponto 1.

Ponto 2: A Figura 32 mostra o ponto 2 onde foi posicionado um tripé entre a vegetação e a parede, com um termo-higrômetro HOBO Onset com proteção contra a radiação solar direta e difusa para as medições da temperatura do ar $\left({ }^{\circ} \mathrm{C}\right)$ e umidade relativa do ar $(\%)$, também a $0,90 \mathrm{~m}$ do piso. 


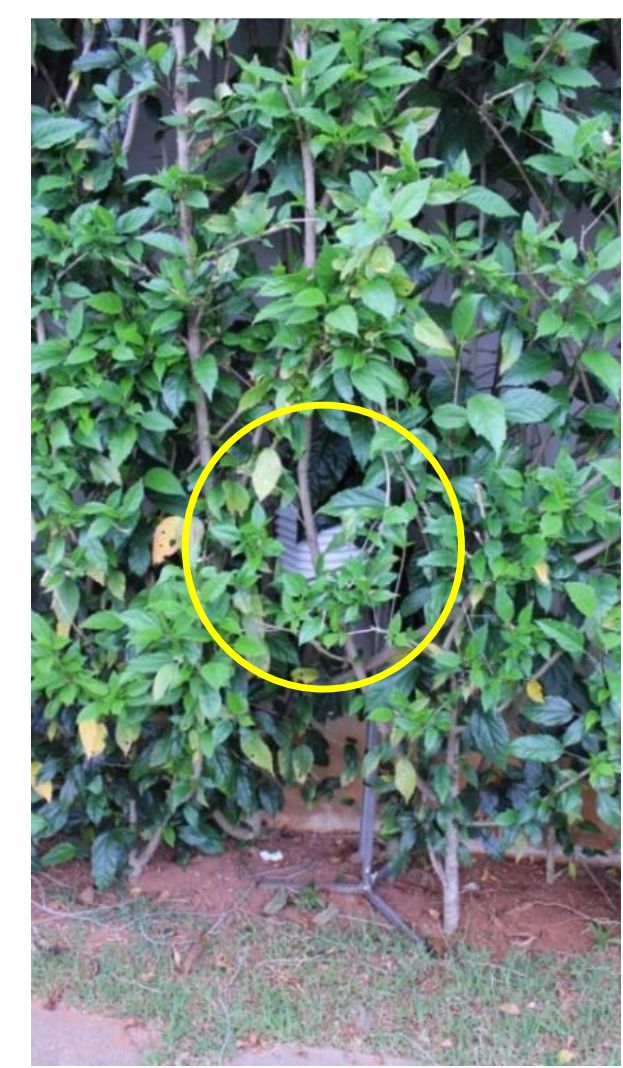

Figura 32 - Localização e posicionamento do ponto 2 de medição.

Pontos 3 e 4: Sensor HOBO Onset com dois canais para medição da temperatura de solo em dois pontos, dentro e fora da vegetação $\left({ }^{\circ} \mathrm{C}\right)$.

\subsubsection{PROCESSO DE MEDIÇÃO}

Os equipamentos foram instalados na noite do dia 05 de dezembro de 2016, e foram programados para iniciar as medições às $23 \mathrm{~h}$ (horário brasileiro de verão). No primeiro dia de medição (06/12/2016) foram registradas imagens de visão de céu as $8 \mathrm{~h}, 12 \mathrm{~h}$ e $20 \mathrm{~h}$, conforme a Figura 33, sob céu claro, sem nuvens, ao longo de todo o período, sendo este o dia mais estável de medição. 

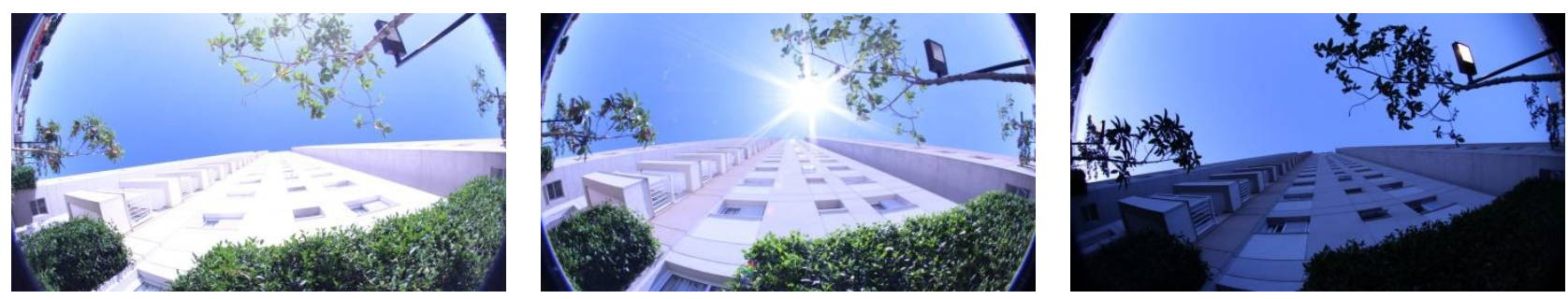

Figura 33 - Visão de céu às 8h, 12 e 20h próxima à fachada estudada.

No segundo dia de medição, repetiu-se a mesma rotina realizada no dia anterior, mas com céu parcialmente nublado a partir das $15 \mathrm{~h}$, com chuva a partir das $16 \mathrm{~h}$ No quarto dia, foi realizada também uma estimativa da densidade de área foliar - DAF, de forma empírica ${ }^{31}$, através da contagem manual das folhas dentro de um cubo imaginário de dimensões 0,50m x 0,50m x 0,50m, conforme mostra a Figura 34, chegando-se ao valor médio de $2000 f o l h a s / \mathrm{m}^{3}$ na área mais densa e $500 f o l h a s / \mathrm{m}^{3}$ na área menos densa. Foi também calculada a área média da folha, de $0,00315 \mathrm{~m}^{2}$.

Através do cálculo do DAF, onde $D A F=\frac{\text { número de folhas } x \text { área da folha }}{1 m^{3}}$ (3), tem-se que 2000folhas $/ \mathrm{m}^{3}$ correspondem a $\mathrm{DAF}=6 \mathrm{~m}^{2} / \mathrm{m}^{3}$. Porém, como a quantidade de folhas variou entre 500 e 2000 folhas $/ \mathrm{m}^{3}$, o DAF calculado para a área menos densa corresponde a $D A F=1,5 \mathrm{~m}^{2} / \mathrm{m}^{3}$. Desta forma, optou-se por considerar $\mathrm{DAF}=3 \mathrm{~m}^{2} / \mathrm{m}^{3}$ para realização das simulações computacionais.

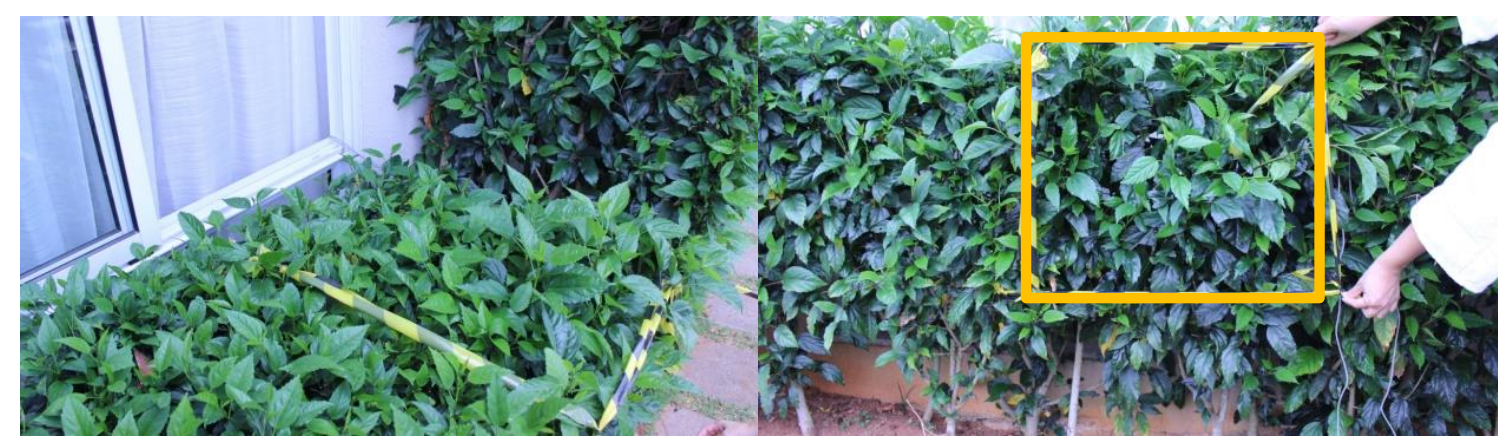

Figura 34 - Área de 50 × 50cm considerada na medição do DAF.

${ }^{31}$ Esse procedimento de medição in loco do DAF para paredes verdes foi recomendado por Helge Simon, um dos desenvolvedores do modelo ENVI-met, durante o estágio BEPE FAPESP n. 2016/01204-7de Paula Shinzato no Johannes Gutenberg-Universität Mainz, em 2016. 


\subsubsection{ANÁLISE DOS RESULTADOS}

A Figura 35 apresenta os resultados de temperatura do ar medidos dentro e fora da vegetação, pontos 1 e 2, comparados com os valores observados no mesmo período na Estação Meteorológica de Observação de Superfície Automática em Barueri, do INMET (OMM86908), sendo esta a estação fixa mais próxima de Taboão da Serra, local da medição. Percebe-se ainda que as temperaturas do ar medidas pelos sensores dentro e fora da vegetação têm um comportamento similar durante todo o período, com exceção de um amortecimento aproximado de $2^{\circ} \mathrm{C}$ proporcionado pela vegetação quando as temperaturas do ar são mais elevadas, no período da tarde, o que pode ser percebido pelo descolamento das curvas dos pontos 1 e 2 na Figura 35, no período noturno, conforme esperado, foi desprezível a diferença na temperatura do ar entre os pontos 1 e 2 .

\section{Temperatura do $\operatorname{Ar}\left({ }^{\circ} \mathrm{C}\right)$}

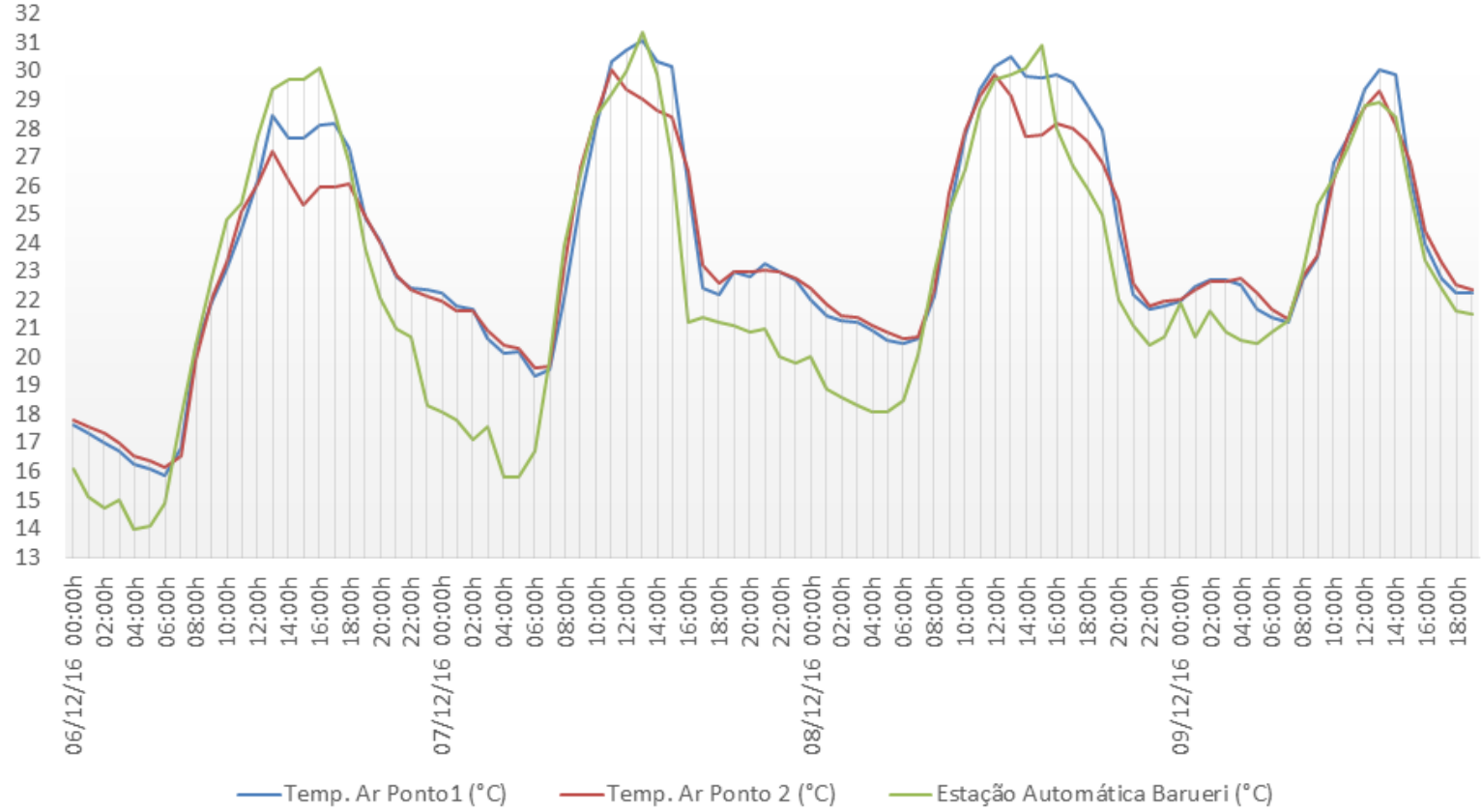

Figura 35 - Temperatura do ar $\left({ }^{\circ} \mathrm{C}\right)$ medida dentro e fora da vegetação nos pontos 1 e 2 , e dados da Plataforma Micrometeorológica IAG USP e da estação automática de Barueri entre $06 / 12 / 16$ e 09/12/16.

Para melhor expressar o conteúdo real de umidade, realizaram-se conversões dos valores da umidade relativa medidos em campo para umidade específica 
(BOLTON, 1980); o gráfico da Figura 36 apresenta os resultados e foi encontrada uma diferença média de $0,24 \mathrm{~g} / \mathrm{kg}$ entre a umidade dentro (P2) e fora da vegetação (P1). Mesmo com uma pequena parcela de solo permeável e vegetação escaladora, sem substrato na vertical, o conteúdo de umidade é sempre um pouco maior entre a vegetação e a fachada do edifício.

Os valores de umidade específica foram calculados através da seguinte equação:

$$
\begin{gathered}
e=6.112^{*} \exp \left[\left(17.67^{*} \text { Tdry }\right) /(\text { Tdry }+243.5)\right] \\
q=\left(0.622{ }^{*} e\right) /(p-(0.378 * e)
\end{gathered}
$$

Onde:

e = pressão de vapor em mb;

Tdry = ponto de condensação da água em ${ }^{\circ} \mathrm{C}$;

$\mathrm{p}=$ pressão superficial em $\mathrm{mb}$;

$q=$ umidade específica em $\mathrm{kg} / \mathrm{kg}$.

(Nota: no gráfico a umidade específica é expressa em $\left.\mathrm{g} / \mathrm{kg}=(\mathrm{kg} / \mathrm{kg})^{\star}{ }^{1000.0}\right)$.

\section{Umidade Específica dentro e fora da vegetação $(\mathrm{g} / \mathrm{kg})$}

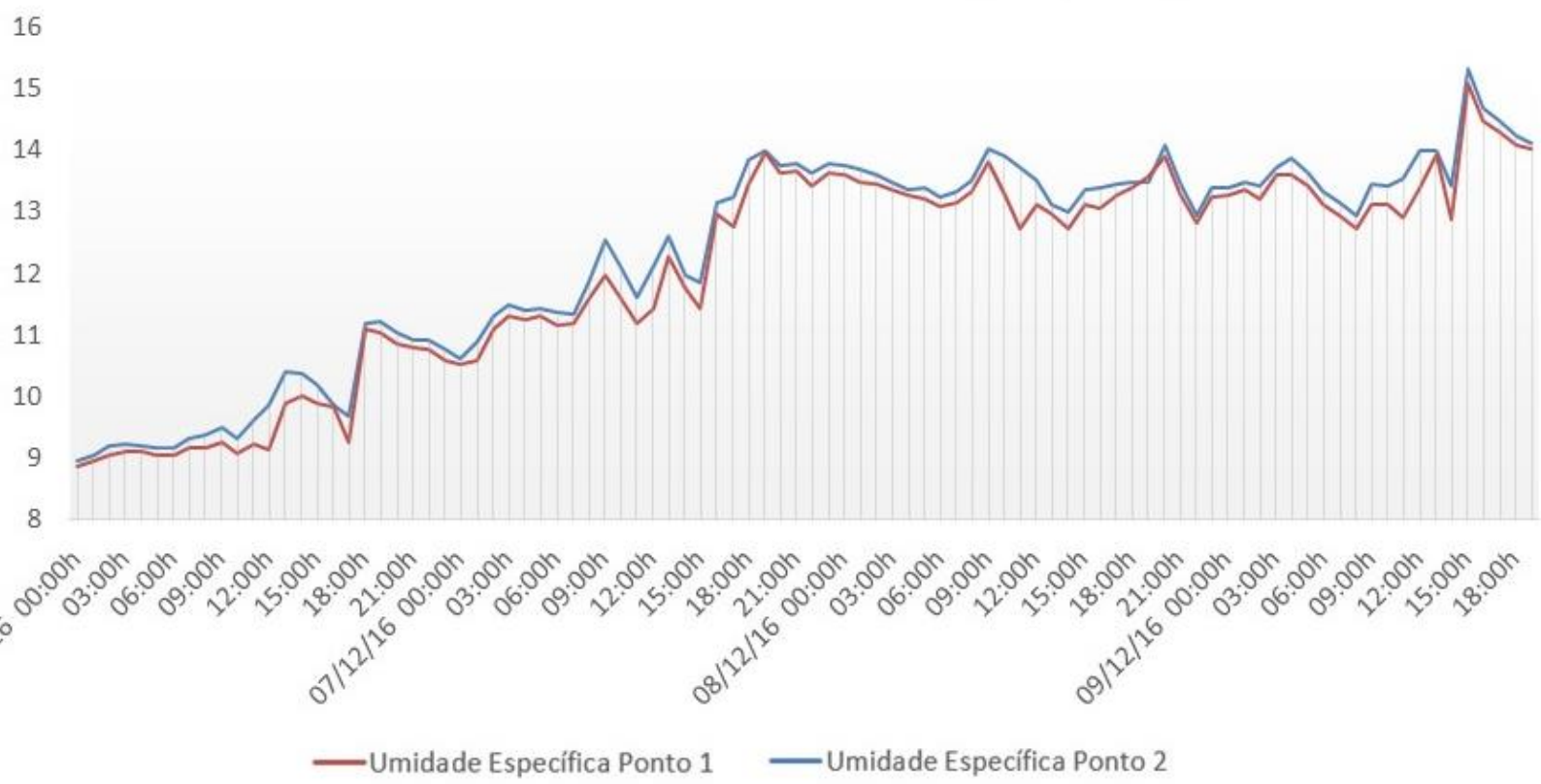

Figura 36 - Umidade específica do ar (g/kg) calculada segundo Bolton (1980). 
O registro dos dados de temperatura de solo foi realizado por dois sensores posicionados em profundidade aproximada de $5 \mathrm{~cm}$, um sob a vegetação e outro a aproximadamente $50 \mathrm{~cm}$ de distância em área não sombreada. O pico de temperatura do solo foi observado sempre às 13h durante o período de medição, salientando que a área estudada passava a ser sombreada pela edificação após esse horário. Foi registrada uma redução de $9^{\circ} \mathrm{C}$ na temperatura de solo sob a vegetação neste horário em relação à temperatura de solo exposta ao sol, sem a sombra da vegetação. Enquanto a temperatura do solo sem vegetação variou de $19,8^{\circ} \mathrm{C}$ a $32,3^{\circ} \mathrm{C}$, representando uma variação máxima de $12,6^{\circ} \mathrm{C}$, observada no primeiro dia de medição, as temperaturas do solo sob a vegetação apresentam uma variação máxima de $3,2^{\circ} \mathrm{C}$ ao longo do dia na pior situação, demonstrando a importância do efeito da vegetação no sombreamento do solo, conforme apresentado na Figura 37.

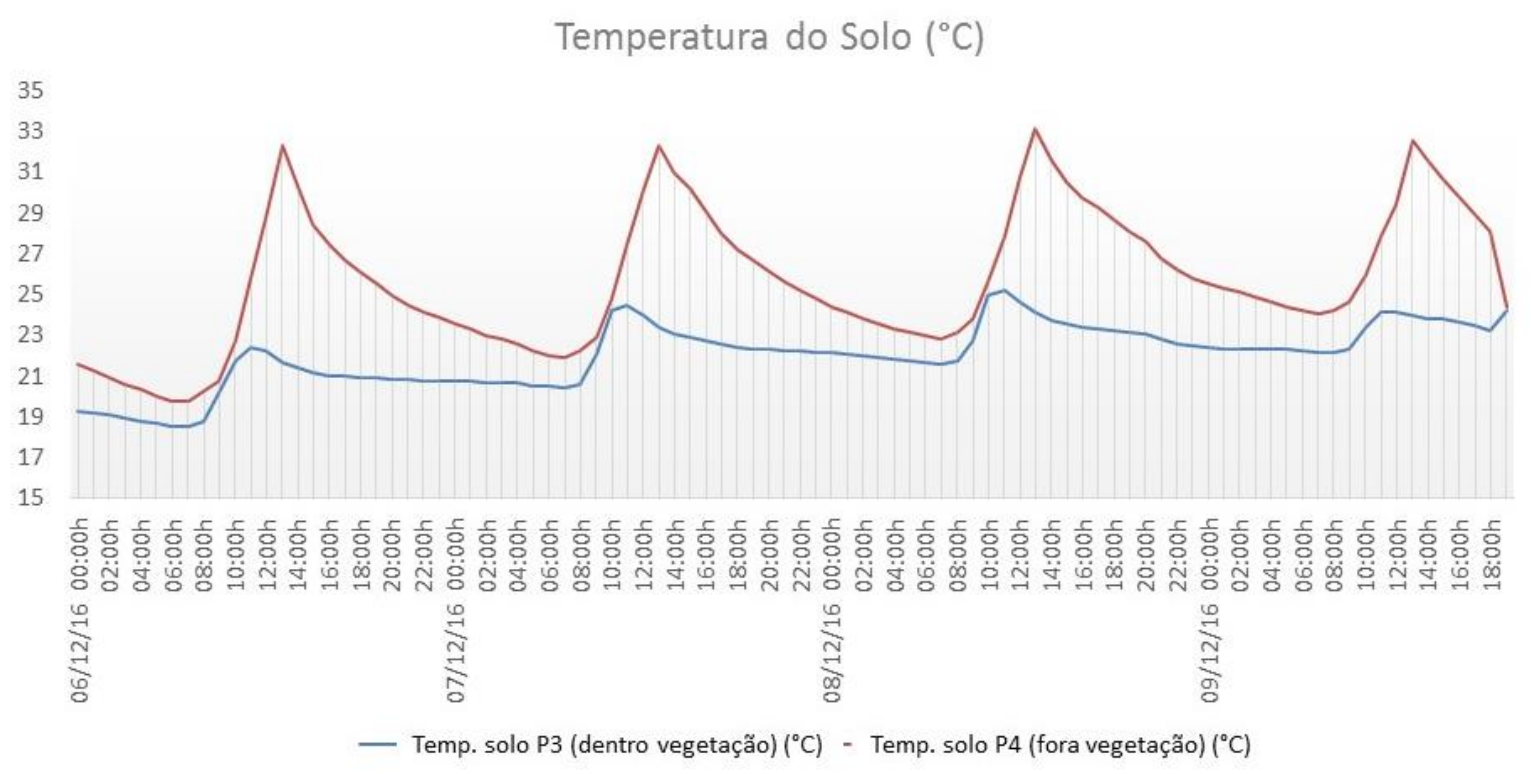

Figura 37 - Temperaturas do solo $\left({ }^{\circ} \mathrm{C}\right)$ medidas dentro $(P 3)$ e fora da vegetação (P4), entre 06/12/16 e 09/12/16.

Na medição de campo utilizou-se termômetro de globo negro fosco de $15 \mathrm{~cm}$ de diâmetro, sobre solo natural coberto por forração vegetal, com caminho em placas cimentícias. $O$ tripé foi posicionado a 1,0 $\mathrm{m}$ de distância da vegetação e $0,50 \mathrm{~m}$ de uma grade com 1,10m de altura, em área sem obstruções significativas, além do próprio edifício em estudo. A Figura 38 apresenta as temperaturas do ar e de globo negro; pelas condições de exposição à radiação 
solar direta e difusa, as temperaturas de globo são muito mais elevadas do que a temperatura do ar, apresentando diferença máxima de $18,9^{\circ} \mathrm{C}$ às $13 \mathrm{~h}$ do primeiro dia de medição, e uma redução drástica a partir das $14 \mathrm{~h}$, quando os sensores ficaram sombreados pela própria edificação, e as duas variáveis praticamente se igualam até novo ganho de radiação solar na manhã seguinte.

\section{Temperatura do Ar e Temperatura de Globo a $1 \mathrm{~m}$ da vegetação $\left({ }^{\circ} \mathrm{C}\right)$}

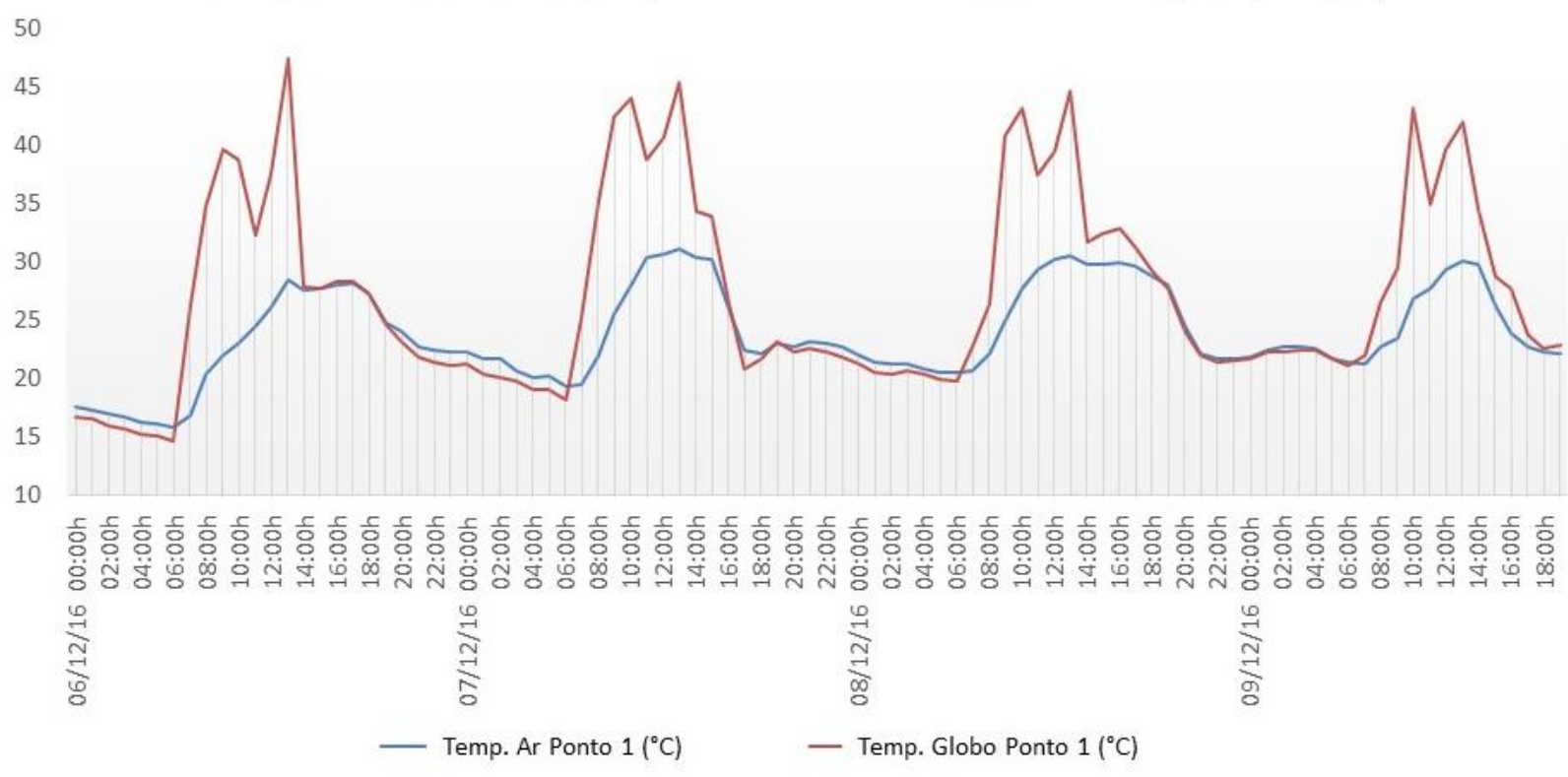

Figura 38 - Temperatura do ar e temperatura de globo $\left({ }^{\circ} \mathrm{C}\right)$ registradas a $1 \mathrm{~m}$ da vegetação, no $P 1$, entre 06/12/16 e 09/12/16. 


\subsection{A MODELAGEM COMPUTACIONAL}

Definiu-se um cenário hipotético para a realização de testes de sensibilidade do modelo à inserção de vegetação escaladora nas paredes de uma edificação, variando-se os parâmetros IAF e umidade do solo.

Em função das características físicas do elemento vegetal a ser estudado, espessura e altura, optou-se pela configuração do tamanho das células da malha ortogonal (grid) que possibilitasse a análise dos efeitos da vegetação de acordo com as pequenas variações microclimáticas esperadas, sob a influência de uma parede verde. A área total modelada foi $60 \times 60$ células, medindo $1 \times 1 \times 1 \mathrm{~m}$ (eixos X; Y; Z) cada. Modelou-se uma edificação com 5 pavimentos ocupando o volume de 10 × 10 × 15 células (eixos X; Y; Z) centralizada na quadra, com vegetação posicionada a $1 \mathrm{~m}$ de distância em todas as faces verticais e 10 células de altura, totalizando $10 \mathrm{~m}$. O posicionamento da vegetação foi determinado para possibilitar o levantamento de informações também entre a parede e a vegetação (Figura 39 e Figura 40).
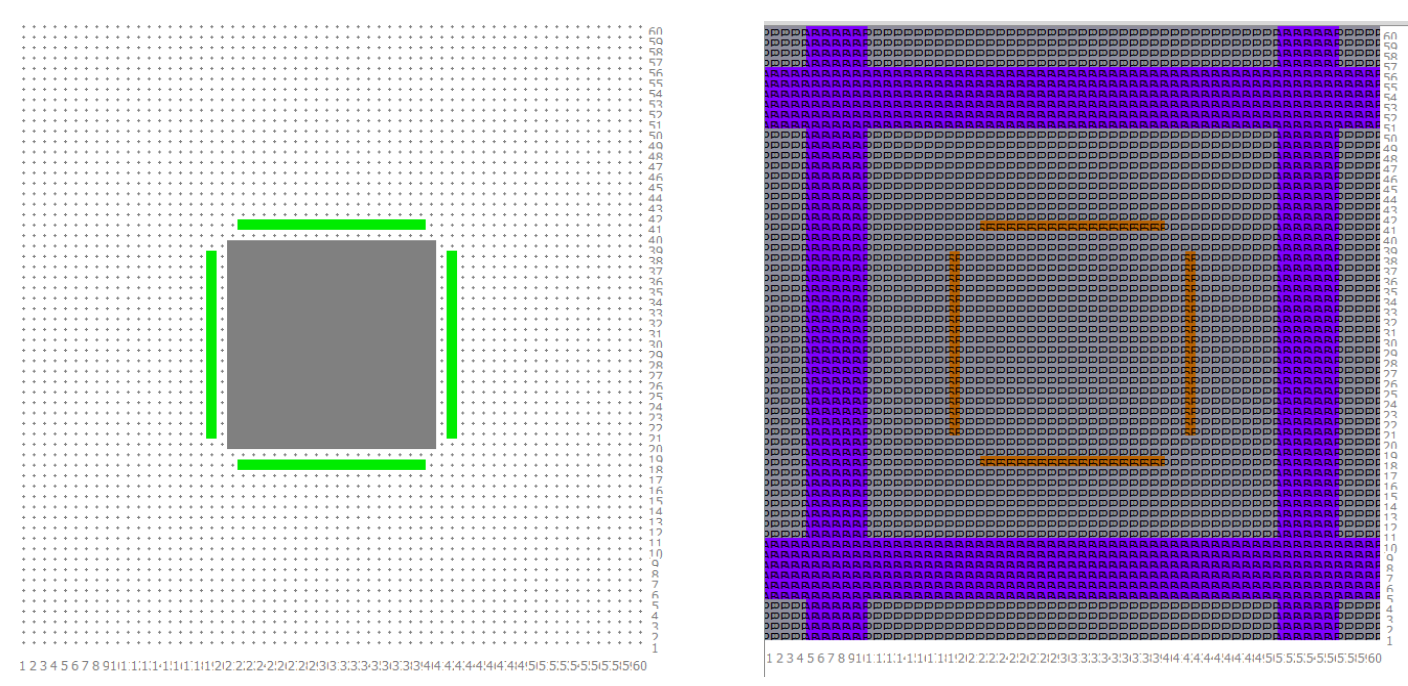

Figura 39 - Disposição da edificação e vegetação na modelagem construída no ENVI-met, layers "Buildings" e "Soil and Surface". 


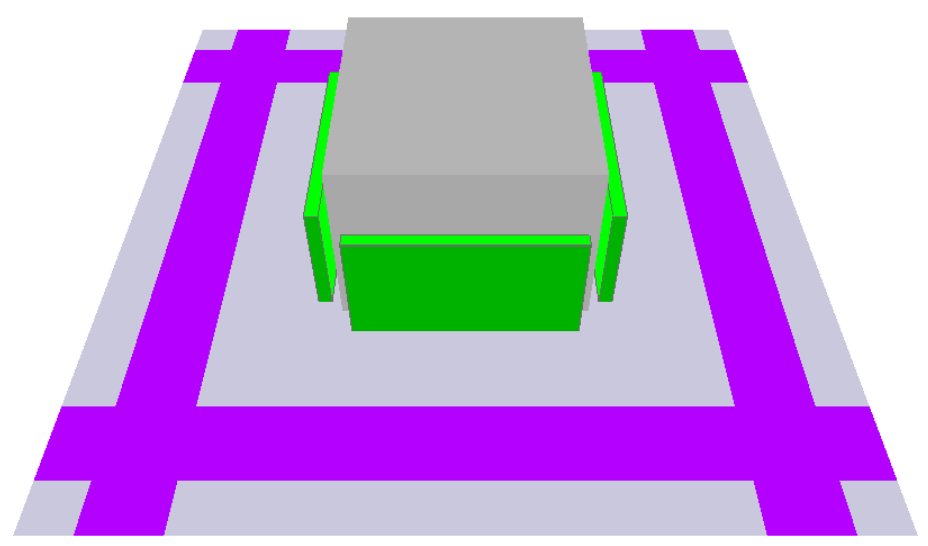

Figura 40 - Visualização 3D do cenário paramétrico simulado, layer "Soil and Surface".

Como dados de entrada do modelo, foram utilizados os seguintes parâmetros, já calibrados para as condições microclimáticas de São Paulo em trabalho anterior (Shinzato, 2017), realizado durante estágio BEPE na Johannes GutenbergUniversität, Mainz, conforme apresentado na Tabela 5, abaixo:

Tabela 5 - Configurações dos parâmetros de entrada.

Data e horário de início
Tempo total de simulação
Velocidade do vento
Direção do vento
Rugosidade
Temperatura atmosférica inicial
Umidade Específica a $2500 \mathrm{~m}$
Umidade relativa ( $\mathrm{h}=2 \mathrm{~m}$ )
Temperatura inicial camada $0-20 \mathrm{~cm}$
Temperatura inicial camada $20-50 \mathrm{~cm}$
Temperatura inicial camada profunda $<50 \mathrm{~cm}$
Umidade relativa camada $0-20 \mathrm{~cm}$
Umidade relativa camada $20-50 \mathrm{~cm}$
Umidade relativa camada profunda $<50 \mathrm{~cm}$
Resistência estômatos
Concentração de $\mathrm{CO}_{2}$

02/04/2016 21:00h 30 horas $1 \mathrm{~m} / \mathrm{s}$ $135^{\circ}$ (Norte $\left.=90\right)$ $0,01 \mathrm{~m}$ $0,0 \mathrm{~K}$ 9,0 (gramas água/kg ar) $75,8 \%$ $294.00 \mathrm{~K}$ 293.00K $296.00 \mathrm{~K}$ $60 \%$ $70 \%$ $75 \%$ 400ppm 
Foram utilizados na configuração do tipo de piso do modelo os perfis desenvolvidos por Gusson (2014) e Shinzato (2014) para São Paulo em trabalhos anteriores, e para isso foram acrescentados ao banco de dados de solo: asfalto para as vias e solo franco-arenoso-argiloso sob a vegetação.

Em função da variação nos dados levantados na estimativa empírica do índice de densidade de área foliar descrito anteriormente, optou-se pela realização de sete simulações paramétricas do cenário modelado (Tabela 6) e comparando-se as variáveis, temperatura do $\operatorname{ar}\left({ }^{\circ} \mathrm{C}\right)$, temperatura de superfície $\left({ }^{\circ} \mathrm{C}\right)$, temperatura radiante média $\left({ }^{\circ} \mathrm{C}\right)$ e umidade específica $(\mathrm{g} / \mathrm{kg})$, conforme apresentado na Tabela 7:

Tabela 6 - Parametrização das simulações

$\begin{array}{lccc}\begin{array}{l}\text { VARIAÇÃO } \\ \text { UMIDADE DO } \\ \text { SOLO }\end{array} & \begin{array}{l}\text { ÍNDICE DE } \\ \text { ÁREA } \\ \text { FOLIAR } \\ \text { (IAF) }\end{array} & \begin{array}{l}\text { TEMPERATURA DO } \\ \text { AR }\left({ }^{\circ} \mathbf{C}\right)\end{array} & \begin{array}{l}\text { TEMPERATURA DE } \\ \text { SUPERFÍCIE }\left({ }^{\circ} \mathbf{C}\right)\end{array} \\ \begin{array}{l}\text { Cenário sem } \\ \text { vegetação }\end{array} & - & \mathbf{X} & \mathbf{X} \\ \text { Umidade 50\% } & 0,5 & \mathbf{X} & \mathbf{X} \\ & 1,0 & \mathbf{X} & \mathbf{X} \\ & 2,0 & \mathbf{X} & \mathbf{X} \\ \text { Umidade 60\% } & 0,5 & \mathbf{X} & \mathbf{X} \\ & 1,0 & \mathbf{X} & \mathbf{X} \\ & 2,0 & \mathbf{X} & \mathbf{X}\end{array}$

1. Cenário sem vegetação;

2. Cenário com vegetação, IAF $0,5 \mathrm{~m}^{2} / \mathrm{m}^{2}$ e umidade do solo $50 \%$;

3. Cenário com vegetação, IAF $1,0 \mathrm{~m}^{2} / \mathrm{m}^{2}$ e umidade do solo $50 \%$;

4. Cenário com vegetação, IAF $2,0 \mathrm{~m}^{2} / \mathrm{m}^{2}$ e umidade do solo $50 \%$;

5. Cenário com vegetação, IAF $0,5 \mathrm{~m}^{2} / \mathrm{m}^{2}$ e umidade do solo $60 \%$;

6. Cenário com vegetação, $\operatorname{IAF} 1,0 \mathrm{~m}^{2} / \mathrm{m}^{2}$ e umidade do solo $60 \%$;

7. Cenário com vegetação, IAF $2,0 \mathrm{~m}^{2} / \mathrm{m}^{2}$ e umidade do solo $60 \%$. 
Tabela 7 - Cruzamento das variáveis.

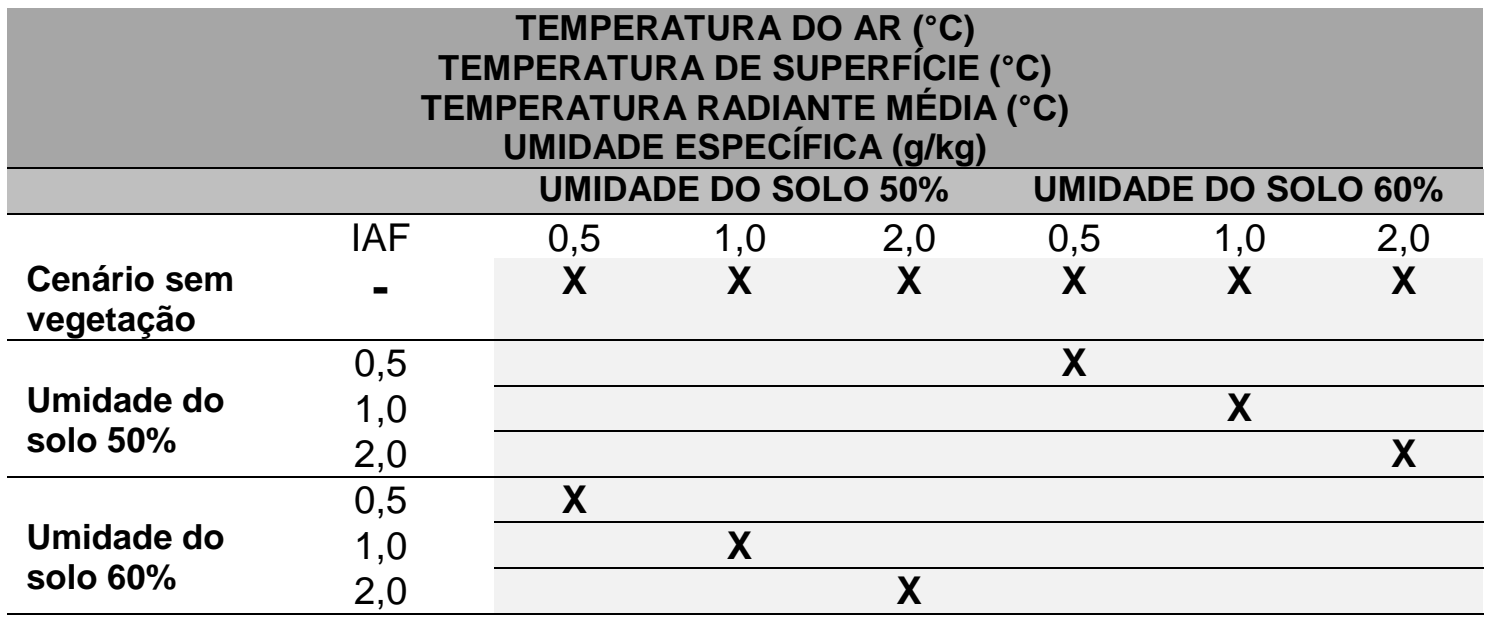

Foi considerada a velocidade constante do vento de $1 \mathrm{~m} / \mathrm{s}$ a fim de se minimizar os efeitos da turbulência, ressaltar o efeito microclimático da vegetação, evitando a instabilidade e erros de convergência de dados na simulação.

Após a modelagem e a introdução dos dados de entrada conforme Shinzato (2017), foram realizadas três etapas de simulação, com a finalidade de realização dos testes de sensibilidade do modelo para as variáveis índice de área foliar e umidade do solo, para posterior comparação dos resultados.
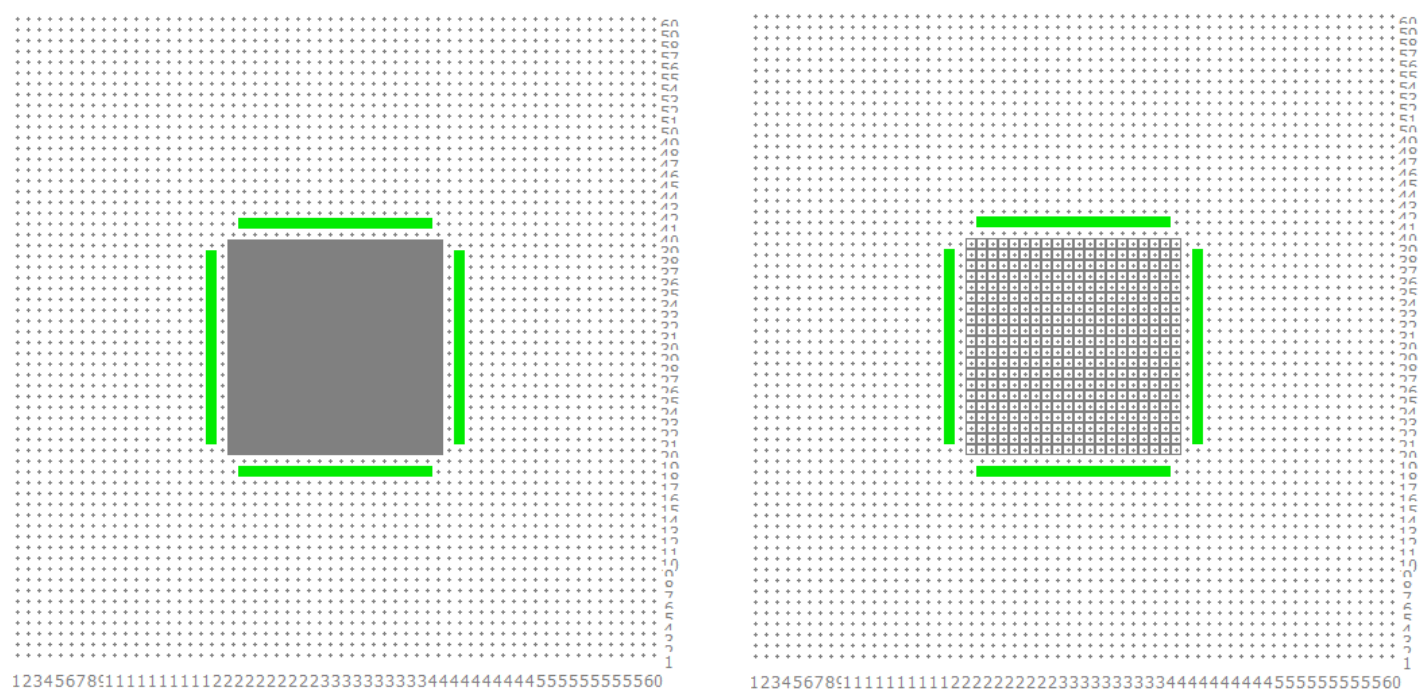

Figura 41 - Layers "Buildings" e "Vegetation" do modelo para os cenários paramétricos. 
Em todos os cenários foram aplicados os mesmos materiais para as ruas, edifício e vegetação, esta última variando apenas o índice de área foliar para IAF=0,5, 1 e $2 \mathrm{~m}^{2} / \mathrm{m}^{2}$.

Foram também consideradas alterações em relação à umidade relativa do solo nas três camadas, sendo que a camada superficial $(0-20 \mathrm{~cm})$ foi simulada com umidade relativa de $50 \%$ e $60 \%$, a faixa intermediária $(20-50 \mathrm{~cm})$ com umidade relativa de $60 \%$ e $70 \%$ e a camada mais profunda (mais de $50 \mathrm{~cm}$ ) com umidade relativa de $70 \%$ e $80 \%$, com o objetivo de se verificar a influência da umidade do solo no processo de evapotranspiração e em um possível impacto na temperatura e umidade do ar.

Para edição e melhor visualização dos resultados foi feita uma padronização na ferramenta Leonardo, no qual foram configuradas as seguintes escalas de cores personalizadas, em função das diferenças de magnitude entre elas (Figura 42 a Figura 46).

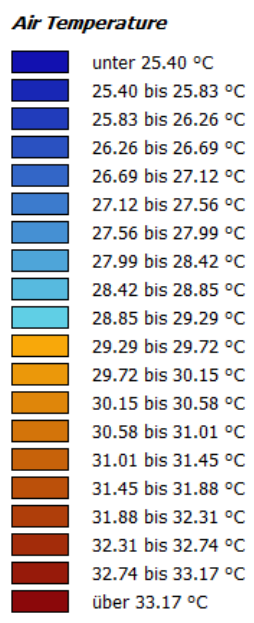

Min: $24.96^{\circ} \mathrm{C}$

Max: $33.61^{\circ} \mathrm{C}$

Figura 42 - escala de cor para temperatura do $a{ }^{\circ} \mathrm{C}$.

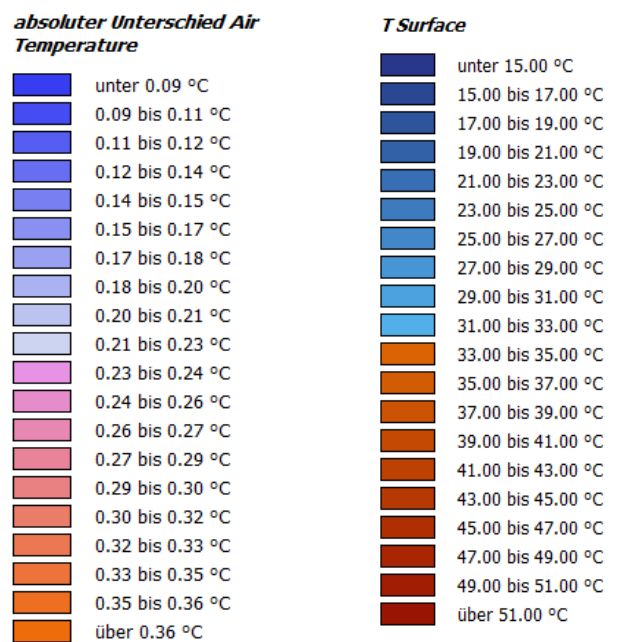
Min: $0.08^{\circ} \mathrm{C}$
Max: $0.37^{\circ} \mathrm{C}$

Figura 43 - escala de cor para diferença de temperatura do ar ${ }^{\circ} \mathrm{C}$
Figura 44 - escala de cor para temperatura de superfície ${ }^{\circ} \mathrm{C}$

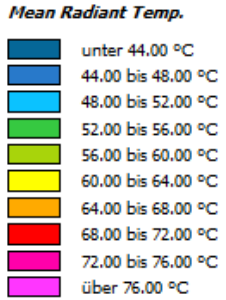

Figura 45 - escala de cor para temperatura média radiante ${ }^{\circ} \mathrm{C}$

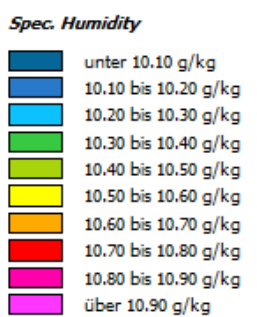

Figura 46 - escala de cor para umidade específica $\mathrm{g} / \mathrm{kg}$

Através da análise da curva da temperatura do ar simulada para os diferentes IAFs, confirmou-se que a temperatura do ar máxima ocorreu às $14 \mathrm{~h}$, conforme 
demonstrado na Figura 47; dessa forma, optou-se por apresentar os resultados e análises realizadas para esse horário.
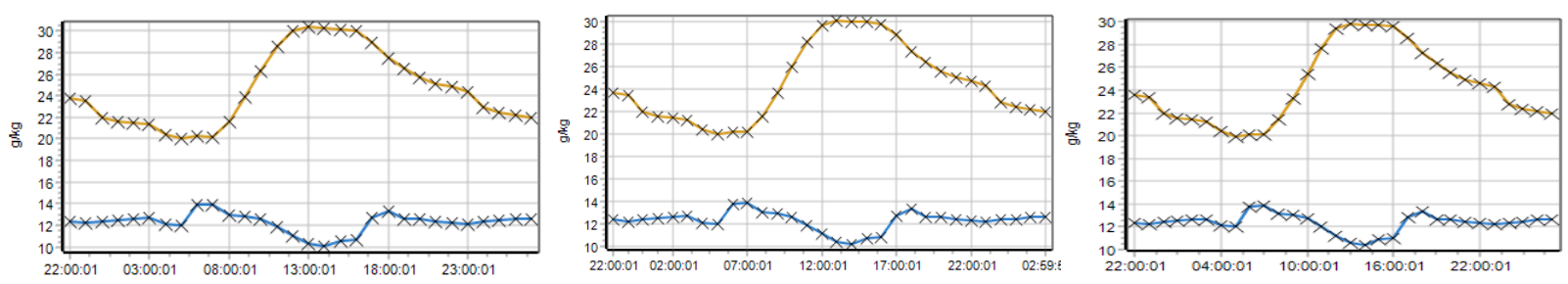

$$
\begin{aligned}
& \text { Legend } \\
& * \text { Air Temperature }\left({ }^{\circ} \mathrm{C}\right) \\
& * \text { Spec. Humidity }(\mathrm{g} / \mathrm{kg})
\end{aligned}
$$

Figura 47 - Temperatura do ar em ${ }^{\circ} \mathrm{C}$ para $I A F=0,5 \mathrm{~m}^{2} / \mathrm{m}^{2}, I A F=1,0 \mathrm{~m}^{2} / \mathrm{m}^{2}$ e $I A F=2,0 \mathrm{~m}^{2} / \mathrm{m}^{2}$.

A ferramenta Leonardo possibilita o cálculo médio das variáveis desejadas através da seleção de uma área determinada no gráfico, neste trabalho foi realizada a extração da temperatura média do ar em cada fachada por este método (Figura 48).

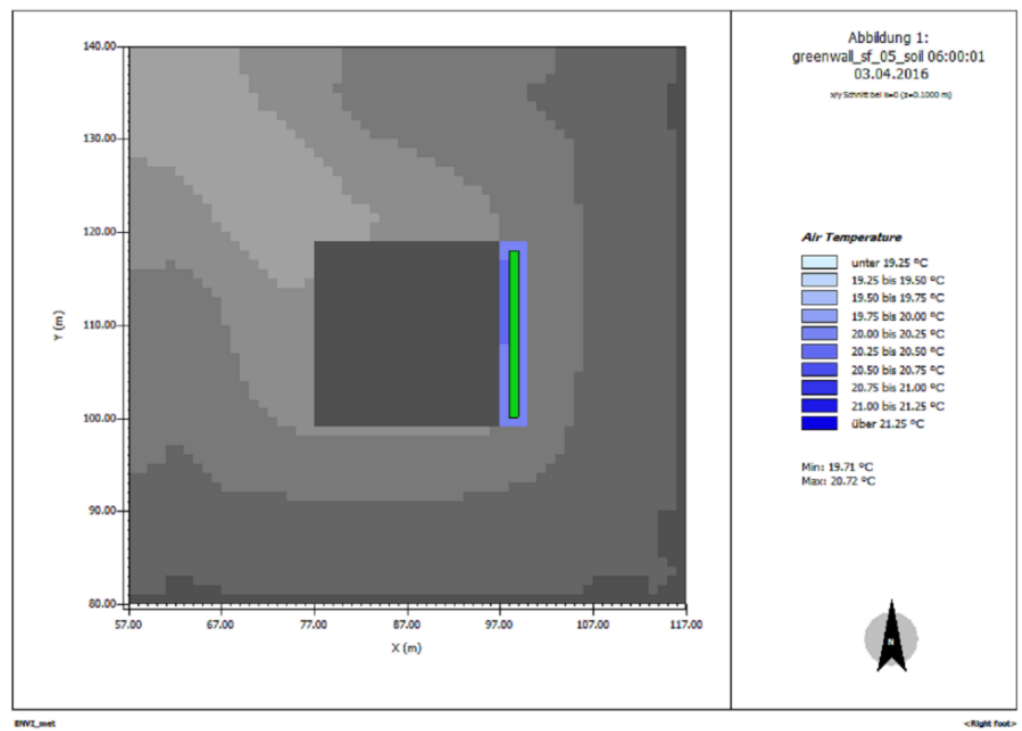

Figura 48 - Exemplo de seleção da área para cálculo da temperatura média do ar realizado com a ferramenta Leonardo. 


\section{ANÁLISE DOS RESULTADOS}

Dadas as restrições e recursos do ENVI-met, foram realizados testes de sensibilidade do modelo em relação às variáveis IAF e umidade do solo, para se avaliar o impacto da vegetação escaladora no microclima externo a um edifício, no seu entorno imediato.

Lembrando, todas as simulações foram executadas para o mês de abril de 2016, pelo fato deste período ter sido calibrado com dados medidos e simulados por Shinzato (2017) durante o estágio FAPESP/BEPE na Johannes GutenbergUniversität Mainz, supervisionado pelo autor do modelo.

Os resultados foram extraídos na altura do pedestre, a 1,50m do solo, em três horários distintos: às $6 \mathrm{~h}$, próximo à temperatura do ar mínima, às $14 \mathrm{~h}$, por se tratar do horário de pico da temperatura do ar, na medição e também nas estações de referência, conforme demonstrado na Figura 35, e às 22h, para se avaliar o efeito do resfriamento noturno, algumas horas após o pôr-do-sol. Às $14 \mathrm{~h}$, nesse período do ano (abril), o sol incide a noroeste no modelo, na latitude de São Paulo. O vento predominante incide na direção sudeste, a $135^{\circ}$ e na simulação foi padronizado com velocidade $1 \mathrm{~m} / \mathrm{s}$ para uma rugosidade $0,01 \mathrm{~m}$, para se minimizar turbulências.

Inicialmente, analisou-se a variação do IAF na Temperatura Radiante Média (TRM) para as umidades relativas do solo 50\% e 60\%, conforme Figura 49 e Figura 50. As imagens demonstram que o incremento da vegetação só e responsável por alterações nos valores da TRM nas células entre a vegetação e a edificação, levando à conclusão de que os efeitos da vegetação sobre a TRM são bastante localizados, tornando sua influência praticamente imperceptível no microclima exterior sob o efeito da radiação solar. Para além disso, a diminuição da TRM é mais evidente na projeção de sombra do edifício, independentemente da vegetação na fachada. 
Sem vegetação

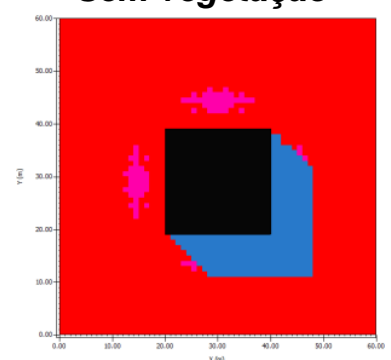

$I A F=1,0$

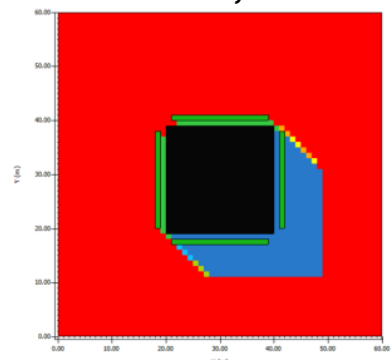

IAF $=0,5$

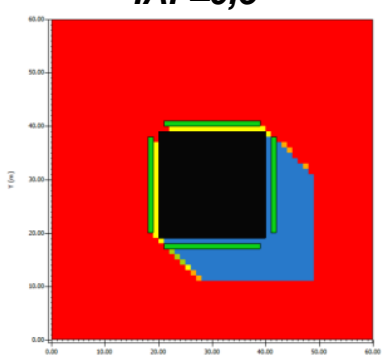

$I A F=2,0$

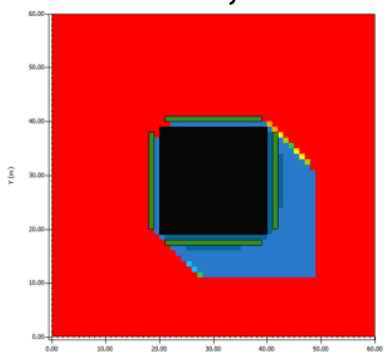

Mean Radiant Temp.

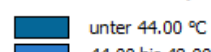
44.00 bis $48.00^{\circ} \mathrm{C}$ 48.00 bis $52.00^{\circ} \mathrm{C}$ 52.00 bis $56.00^{\circ} \mathrm{C}$ 56.00 bis $60.00^{\circ} \mathrm{C}$ 60.00 bis $64.00^{\circ} \mathrm{C}$ 64.00 bis $68.00^{\circ} \mathrm{C}$ 68.00 bis $72.000^{\circ} \mathrm{C}$ über $76.00^{\circ} \mathrm{C}$

Min: $45.48^{\circ} \mathrm{C}$ Max: $72.14^{\circ} \mathrm{C}$

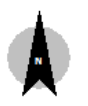

Figura 49 - Temperatura radiante média para $I A F=0,5 \mathrm{~m}^{2} / \mathrm{m}^{2}, I A F=1,0 \mathrm{~m}^{2} / \mathrm{m}^{2}$ e $I A F=2,0 \mathrm{~m}^{2} / \mathrm{m}^{2}$ e umidade relativa do solo $50 \%$ às $14 \mathrm{~h}$.

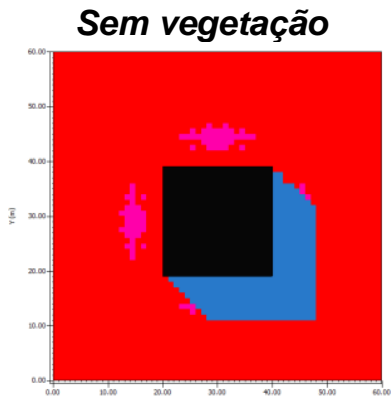

$I A F=1,0$

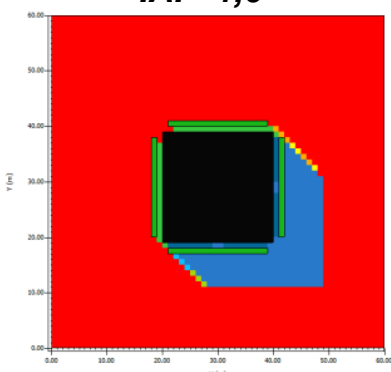

$I A F=0,5$

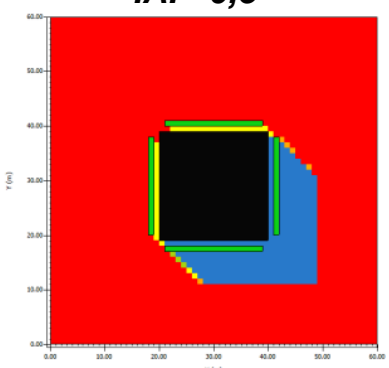

$I A F=2,0$

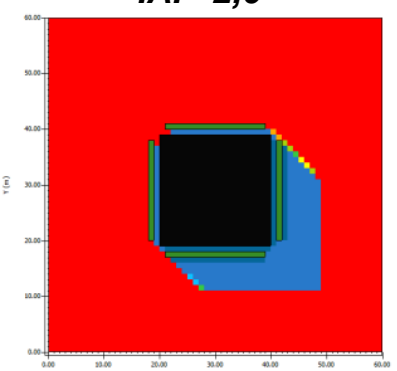

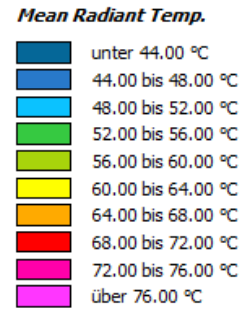

Min: $45.48^{\circ} \mathrm{C}$ Max: $72.14^{\circ} \mathrm{C}$

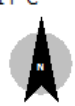

Figura 50 - Temperatura radiante média para $I A F=0,5 \mathrm{~m}^{2} / \mathrm{m}^{2}, I A F=1,0 \mathrm{~m}^{2} / \mathrm{m}^{2}$ e $I A F=2,0 \mathrm{~m}^{2} / \mathrm{m}^{2}$ e umidade relativa do solo $60 \%$ às $14 \mathrm{~h}$.

Como resultado do sombreamento provocado pela vegetação também pode-se observar uma pequena variação na TRM quando analisada a influência da variação na umidade relativa do solo, para o mesmo IAF. A Figura 51 mostra uma pequena redução da TRM com o aumento do IAF, onde a variação da umidade relativa do solo proporciona uma redução de $0,01^{\circ} \mathrm{C}$ na TRM sob a vegetação, e de $0,03^{\circ} \mathrm{C}$ na TRM entre a vegetação e a edificação. 

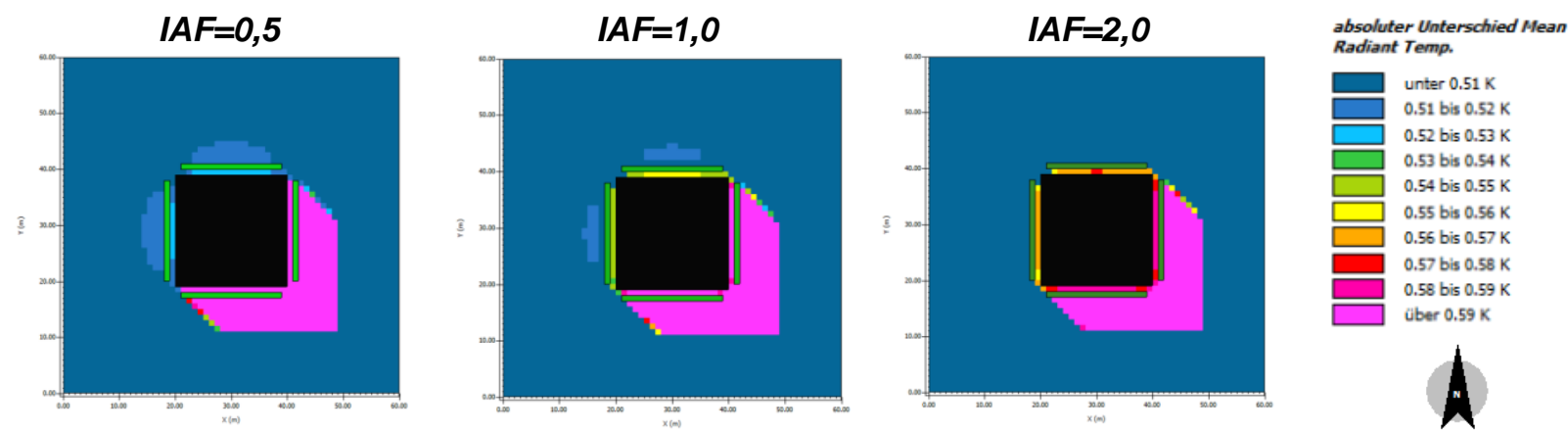

Figura 51 - Diferença da TRM (K) para $I A F=0,5 \mathrm{~m}^{2} / \mathrm{m}^{2}, I A F=1,0 \mathrm{~m}^{2} / \mathrm{m}^{2}$ e $I A F=2,0 \mathrm{~m}^{2} / \mathrm{m}^{2}$ e variação da umidade relativa do solo $50 \%$ e $60 \%$ às $14 \mathrm{~h}$.

Foram testados os cenários sem vegetação e com vegetação para IAF= $0,5 \mathrm{~m}^{2} / \mathrm{m}^{2}, I A F=1,0 \mathrm{~m}^{2} / \mathrm{m}^{2}$ e $I A F=2,0 \mathrm{~m}^{2} / \mathrm{m}^{2}$, às $6 \mathrm{~h}$, portanto, pouco antes da entrada de radiação no modelo para essa latitude e período do ano (Figura 52 e Figura 53) com a umidade do solo em 50\%, por recomendação da equipe de desenvolvimento do ENVI-met em Mainz, como valor mínimo necessário para se evitar o estresse hídrico na simulação. Posteriormente a umidade do solo foi testada também a $60 \%$, e assim, sucessivamente, em todos os cenários. Todos os resultados foram extraídos através da ferramenta de edição e visualização Leonardo, plug-in para o ENVI-met.

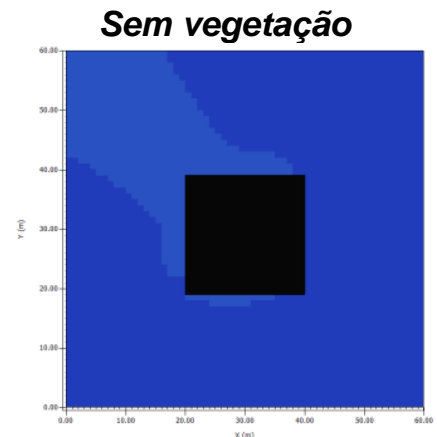

$I A F=1,0$

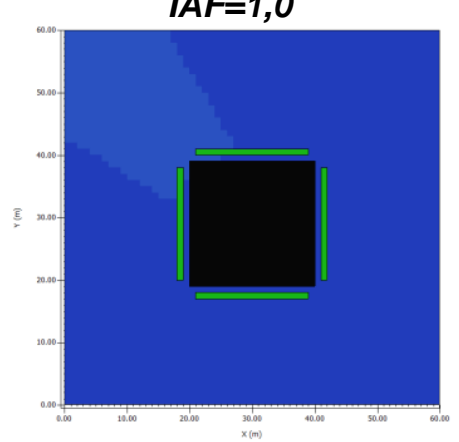

$I A F=0,5$

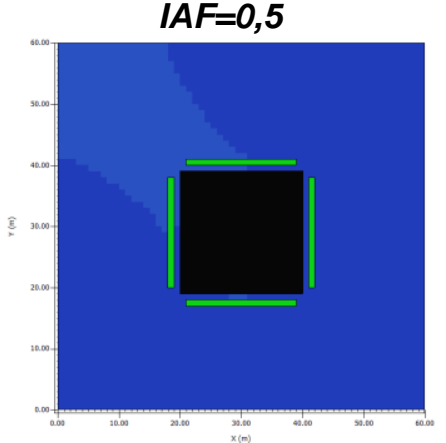

$I A F=2,0$

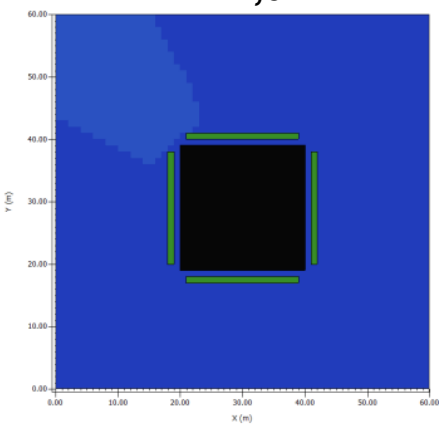

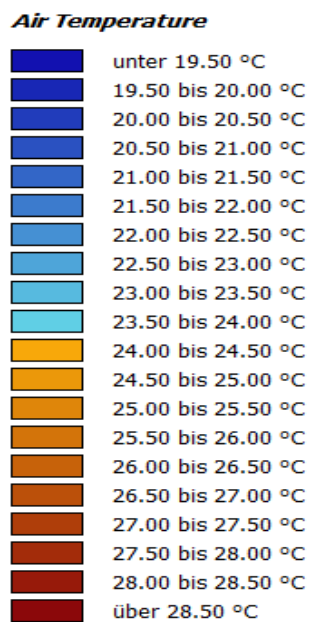

Min: $19.53^{\circ} \mathrm{C}$ Max: $20.80^{\circ} \mathrm{C}$

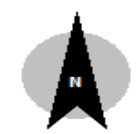

Figura 52 - Temperatura do ar simulada com umidade relativa do solo de $50 \%$ nos cenários sem vegetação e com vegetação para $I A F=0,5 \mathrm{~m}^{2} / \mathrm{m}^{2}, I A F=1,0 \mathrm{~m}^{2} / \mathrm{m}^{2}$ e $I A F=2,0 \mathrm{~m}^{2} / \mathrm{m}^{2}$ às 6 horas, $h=1,50 \mathrm{~m}$. 


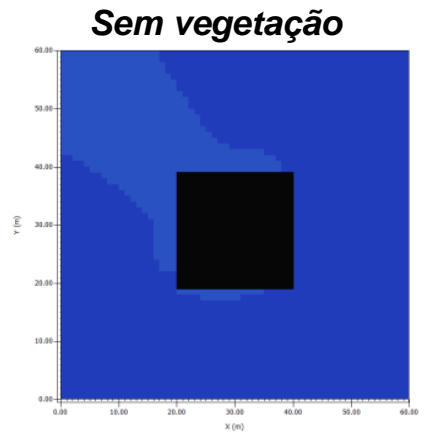

$I A F=1,0$

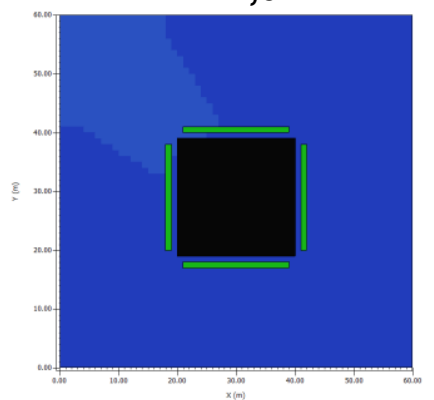

$I A F=0,5$

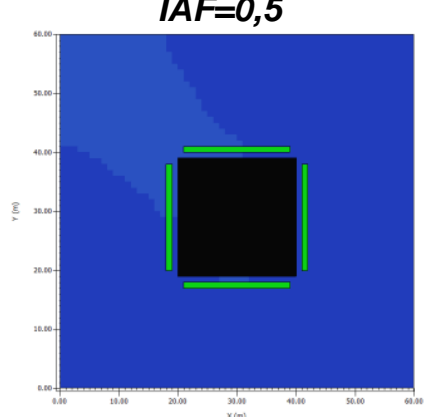

$I A F=2,0$

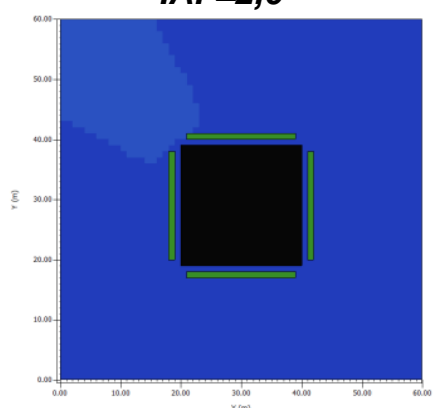

Air Temperature

Air Temperature
unter $19.50^{\circ} \mathrm{C}$

19.50 bis $20.00^{\circ} \mathrm{C}$

20.00 bis $20.50^{\circ} \mathrm{C}$

20.50 bis $21.00^{\circ} \mathrm{C}$

21.00 bis $21.50^{\circ} \mathrm{C}$

21.50 bis $22.00^{\circ} \mathrm{C}$

22.00 bis $22.50^{\circ} \mathrm{C}$

22.50 bis $23.00^{\circ} \mathrm{C}$

23.00 bis $23.50^{\circ} \mathrm{C}$

23.50 bis $24.00^{\circ} \mathrm{C}$

24.00 bis $24.50^{\circ} \mathrm{C}$

24.50 bis $25.00^{\circ} \mathrm{C}$

25.00 bis $25.50^{\circ} \mathrm{C}$

25.50 bis $26.00^{\circ} \mathrm{C}$

26.00 bis $26.50^{\circ} \mathrm{C}$

26.50 bis $27.00^{\circ} \mathrm{C}$

27.00 bis $27.50^{\circ} \mathrm{C}$

27.50 bis $28.00^{\circ} \mathrm{C}$

28.00 bis $28.50^{\circ} \mathrm{C}$

über $28.50^{\circ} \mathrm{C}$

Min: $19.53^{\circ} \mathrm{C}$

Max: $20.80^{\circ} \mathrm{C}$

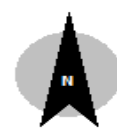

Figura 53 - Temperatura do ar simulada com umidade relativa do solo de $60 \%$ nos cenários sem vegetação e com vegetação para $I A F=0,5 \mathrm{~m}^{2} / 2, I A F=1,0 \mathrm{~m}^{2} / \mathrm{m} 2$ e $I A F=2,0 \mathrm{~m}^{2} / \mathrm{m}^{2}$ às $6 h o r a s$, $h=1,50 \mathrm{~m}$.

Comparando-se o cenário sem vegetação e com vegetação para IAF $0,5 \mathrm{~m}^{2} / \mathrm{m}^{2}$, $1,0 \mathrm{~m}^{2} / \mathrm{m}^{2}$ e $2,0 \mathrm{~m}^{2} / \mathrm{m}^{2}$ e umidade do solo $50 \%$, às $6 \mathrm{~h}$, pouco antes da entrada de radiação no modelo, pode-se observar na Figura 54 abaixo uma redução máxima na temperatura do ar no entorno imediato do modelo de $0,12^{\circ} \mathrm{C}, 0,25^{\circ} \mathrm{C}$ e $0,55^{\circ} \mathrm{C}$, respectivamente, com o incremento da vegetação. A mesma ordem de grandeza foi observada para os cenários com $60 \%$ de umidade do solo. Nesse horário, às 6h, a evapotranspiração ainda não acontece, e as trocas são principalmente convectivas; percebe-se também uma diferença mínima, da ordem de $0,05^{\circ} \mathrm{C}$, entre os cenários com $50 \%$ e $60 \%$ de umidade.

IAF $=0,5$
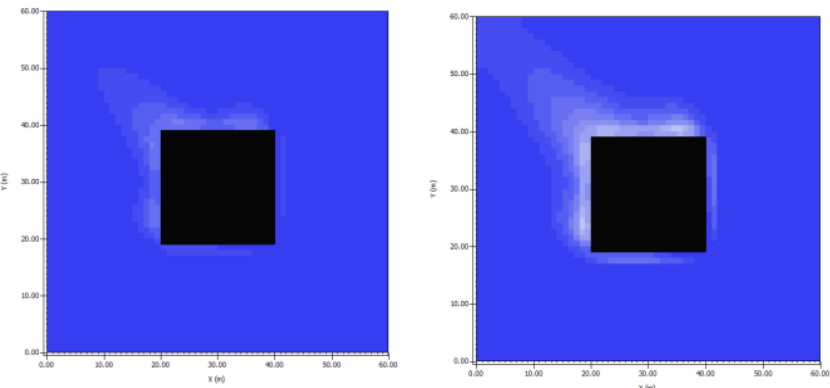

IAF $=1,0$

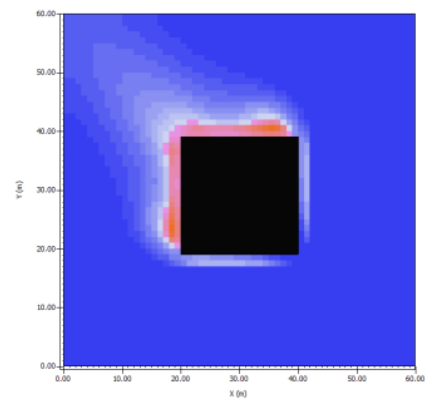

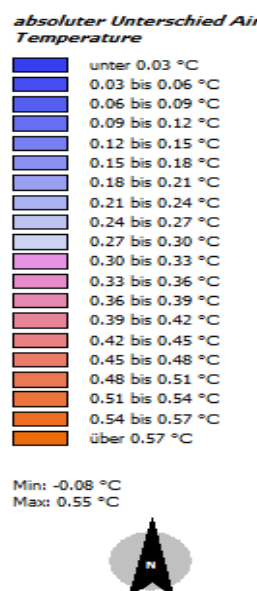

Figura 54 - Diferença de temperatura do ar para $I A F=0,5 \mathrm{~m}^{2} / \mathrm{m}^{2}, I A F=1,0 \mathrm{~m}^{2} / \mathrm{m}^{2}$ e $I A F=2,0 \mathrm{~m}^{2} / \mathrm{m}^{2}$ com relação ao cenário sem vegetação para umidade relativa do solo $50 \%$ às $6 h, h=1,50 \mathrm{~m}$. 
Percebe-se na Figura 55 e Figura 56 geradas para as 14h, portanto, sob o efeito da evapotranspiração, que, com o aumento gradual do IAF, a área no entorno imediato do edifício sofre uma diminuição das temperaturas do ar, indicando a sensibilidade do modelo para essa variável. Esse efeito se prolonga espacialmente um pouco mais a sotavento, mesmo com baixa velocidade do ar, a $1 \mathrm{~m} / \mathrm{s}$, indicando o transporte que ocorre pela ação do vento.

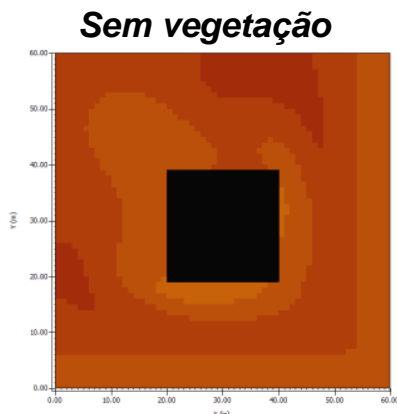

IAF $=1,0$

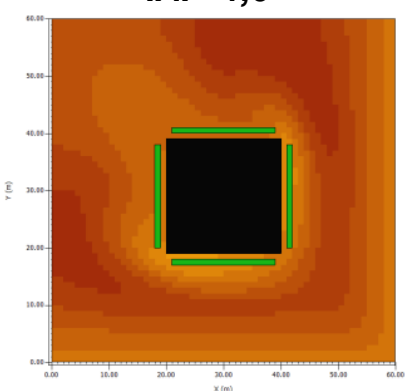

$I A F=0,5$

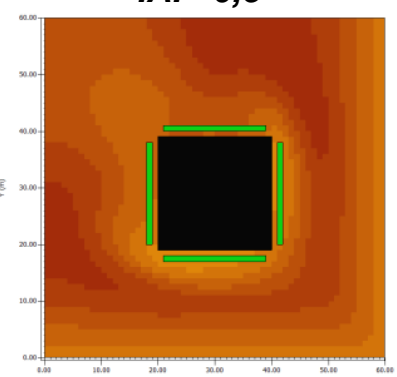

$I A F=2,0$

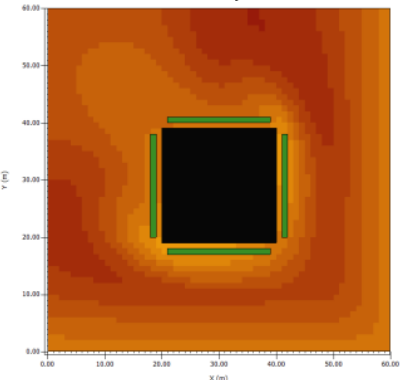

Air Temperature

unter $19.75^{\circ} \mathrm{C}$ 19.75 bis $20.50^{\circ} \mathrm{C}$ 20.50 bis $21.25^{\circ} \mathrm{C}$ 21.25 bis $22.00^{\circ} \mathrm{C}$ 22.00 bis $22.75^{\circ} \mathrm{C}$ 22.75 bis $23.50^{\circ} \mathrm{C}$ 23.50 bis $24.25^{\circ} \mathrm{C}$ 24.25 bis $25.00^{\circ} \mathrm{C}$ 25.00 bis $25.75^{\circ} \mathrm{C}$ 25.75 bis $26.50^{\circ} \mathrm{C}$ 26.50 bis $27.25^{\circ} \mathrm{C}$ 27.25 bis $28.00^{\circ} \mathrm{C}$ 28.00 bis $28.75^{\circ} \mathrm{C}$ 28.75 bis $29.50^{\circ} \mathrm{C}$ 29.50 bis $30.25^{\circ} \mathrm{C}$ 30.25 bis $31.00^{\circ} \mathrm{C}$ 31.00 bis $31.75^{\circ} \mathrm{C}$ 31.75 bis $32.50^{\circ} \mathrm{C}$ 32.50 bis $33.25^{\circ} \mathrm{C}$ über $33.25^{\circ} \mathrm{C}$

Min: $29.89^{\circ} \mathrm{C}$ Max: $32.00^{\circ} \mathrm{C}$

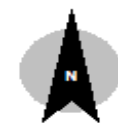

Figura 55 - Temperatura do ar simulada com umidade relativa do solo de $50 \%$, cenários sem vegetação e com vegetação $I A F=0,5 m^{2} / 2, I A F=1,0 m^{2} / m^{2}$ e $I A F=2,0 m^{2} / m^{2}$ às $14 h o r a s, ~ h=1,50 m$.

Sem vegetação

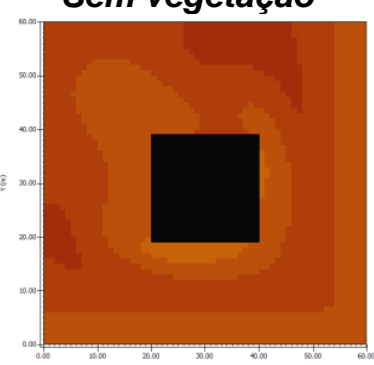

$I A F=1,0$

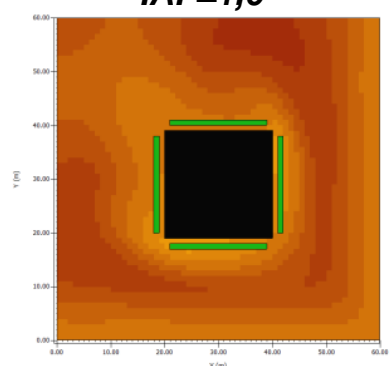

$I A F=0,5$

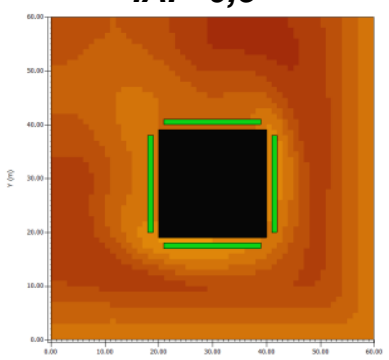

$I A F=2,0$

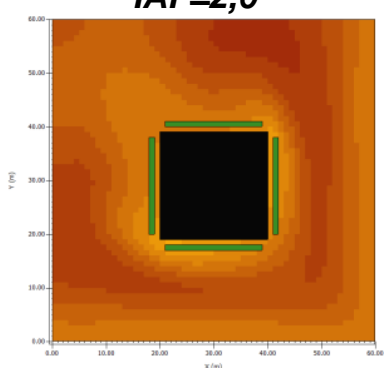

Air Temperature

unter $19.75^{\circ} \mathrm{C}$ 19.75 bis $20.50^{\circ} \mathrm{C}$ 20.50 bis $21.25^{\circ} \mathrm{C}$ 21.25 bis $22.00^{\circ} \mathrm{C}$ 22.00 bis $22.75^{\circ} \mathrm{C}$ 22.75 bis $23.50^{\circ} \mathrm{C}$ 23.50 bis $24.25^{\circ} \mathrm{C}$ 24.25 bis $25.00^{\circ} \mathrm{C}$ 25.00 bis $25.75^{\circ} \mathrm{C}$ 25.75 is $25.75 \circ$ 25.50 is $27.25^{\circ} \mathrm{C}$ 26.50 bis $27.25^{\circ} \mathrm{C}$ 27.25 bis $28.00^{\circ} \mathrm{C}$ 28.00 bis $28.75^{\circ} \mathrm{C}$ 28.75 bis $29.50^{\circ} \mathrm{C}$ 29.50 bis $30.25^{\circ} \mathrm{C}$ 30.25 bis $31.00^{\circ} \mathrm{C}$ 31.00 bis $31.75^{\circ} \mathrm{C}$ 31.75 bis $32.50^{\circ} \mathrm{C}$ 31.75 bis $32.50^{\circ} \mathrm{C}$ über $33.25^{\circ} \mathrm{C}$

Min: $29.89^{\circ} \mathrm{C}$

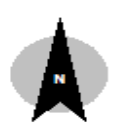

Figura 56 - Temperatura do ar simulada com umidade relativa do solo de $60 \%$, cenários sem vegetação e com vegetação $I A F=0,5 \mathrm{~m}^{2} / \mathrm{m}^{2}$, IAF=1,0 $\mathrm{m}^{2} / \mathrm{m}^{2}$ e $I A F=2,0 \mathrm{~m}^{2} / \mathrm{m}^{2}$ às 14 horas, $h=1,50 \mathrm{~m}$. 
Comparando-se o cenário sem vegetação e com vegetação para IAF $0,5 \mathrm{~m}^{2} / \mathrm{m}^{2}$, $1,0 \mathrm{~m}^{2} / \mathrm{m}^{2}$ e $2,0 \mathrm{~m}^{2} / \mathrm{m}^{2}$ e umidade do solo $50 \%$, às $14 \mathrm{~h}$, pode-se observar na Figura 57 e 58 abaixo uma redução máxima na temperatura do ar no entorno imediato do edifício de $0,17^{\circ} \mathrm{C}, 0,36^{\circ} \mathrm{C}$ e $0,68^{\circ} \mathrm{C}$, respectivamente, com o incremento da vegetação. A Figura 58 representa as diferenças de temperatura do ar para umidade de $60 \%$, chegando a uma redução de $0,44^{\circ} \mathrm{C}, 0,66^{\circ} \mathrm{C}$ e $0,99^{\circ} \mathrm{C}$ para os mesmos incrementos do IAF, mostrando a influência da umidade do solo no resfriamento evaporativo no entorno do edifício.

IAF $=0,5$
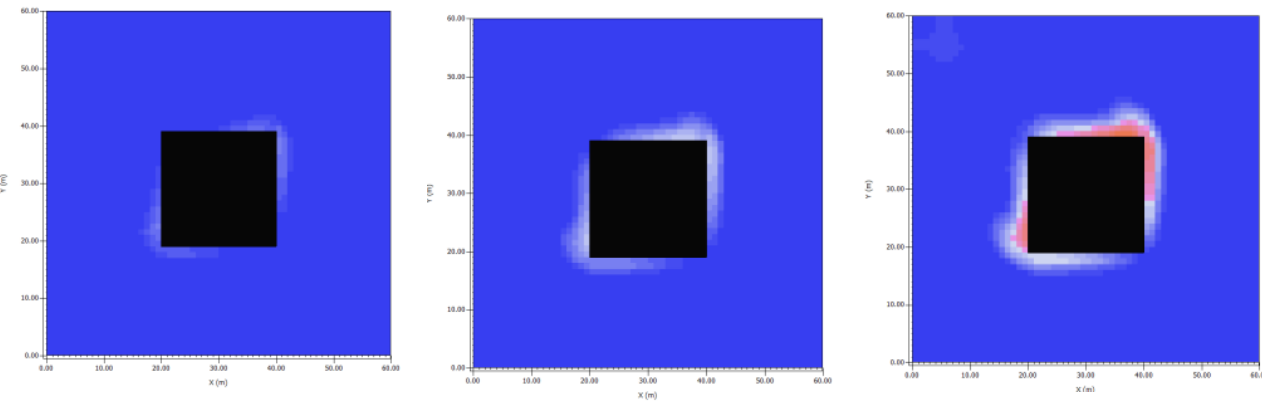

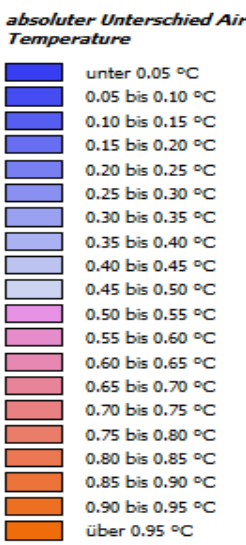

Min: $0.03^{\circ} \mathrm{C}$ $\operatorname{Max}: 0.99^{\circ} \mathrm{C}$

Figura 57 - Diferença de temperatura do ar para $I A F=0,5 \mathrm{~m}^{2} / \mathrm{m}^{2}, I A F=1,0 \mathrm{~m}^{2} / \mathrm{m}^{2}$ e $I A F=2,0 \mathrm{~m}^{2} / \mathrm{m}^{2}$ com relação ao cenário sem vegetação para umidade relativa do solo $50 \%$ às $14 \mathrm{~h}, \mathrm{~h}=1,50 \mathrm{~m}$.

$I A F=0,5$
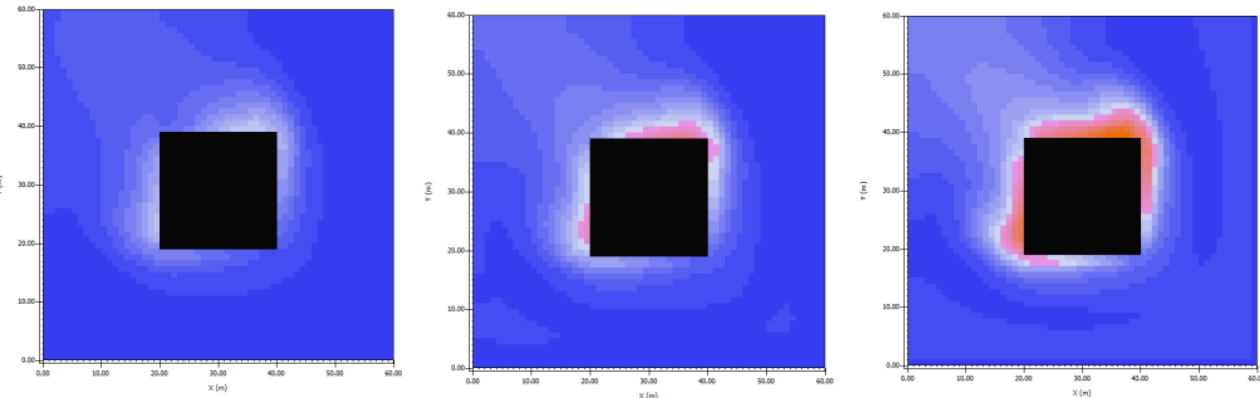

$I A F=2,0$

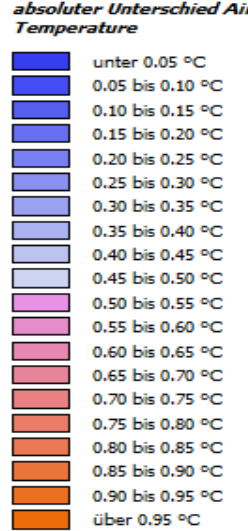

Min: $0.03^{\circ} \mathrm{C}$
Max: $0.99^{\circ} \mathrm{C}$

Figura 58 - Diferença de temperatura do ar para $I A F=0,5 \mathrm{~m}^{2} / \mathrm{m}^{2}, I A F=1,0 \mathrm{~m}^{2} / \mathrm{m}^{2}$ e $I A F=2,0 \mathrm{~m}^{2} / \mathrm{m}^{2}$ com relação ao cenário sem vegetação para umidade relativa do solo $60 \%$ às $14 \mathrm{~h}, \mathrm{~h}=1,50 \mathrm{~m}$. 
Sem o efeito da evapotranspiração, às $22 \mathrm{~h}$, o efeito do vento parece ser mais significativo para o resfriamento do entorno imediato do edifício, com temperaturas do ar menores a barlavento. Durante o dia percebe-se claramente o efeito da evapotranspiração; à noite, não, e o resfriamento noturno parece ser mais influenciado pela troca convectiva, do que pela vegetação (Figura 59 e Figura 60), indicando um comportamento térmico distinto da parede verde nos períodos diurno e noturno.

Sem vegetação

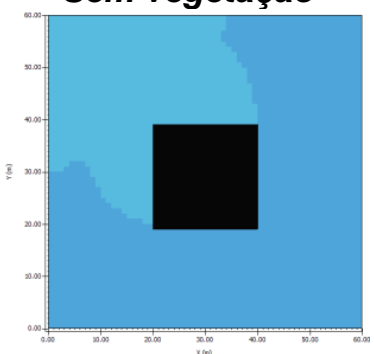

$I A F=1,0$

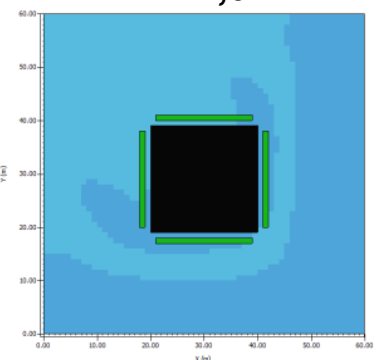

$I A F=0,5$

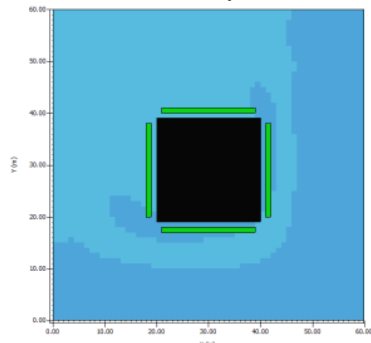

$I A F=2,0$

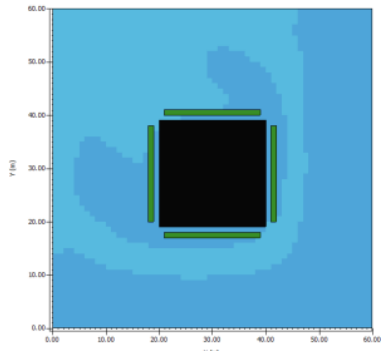

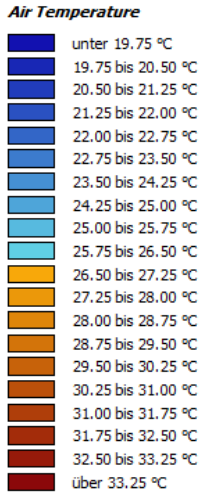

Min: $24.85^{\circ} \mathrm{C}$
Max: $25.32{ }^{\circ} \mathrm{C}$

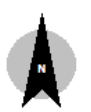

Figura 59 - Temperatura do ar simulada com umidade relativa do solo de $50 \%$ nos cenários sem vegetação e com vegetação para $I A F=0,5 \mathrm{~m}^{2} / \mathrm{m}^{2}, I A F=1,0 \mathrm{~m}^{2} / \mathrm{m}^{2}$ e $I A F=2,0 \mathrm{~m}^{2} / \mathrm{m}^{2}$ às 22horas.

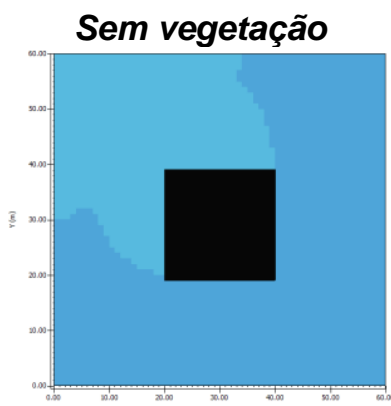

$I A F=1,0$

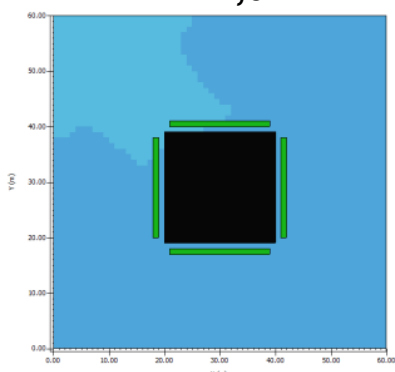

IAF $=0,5$

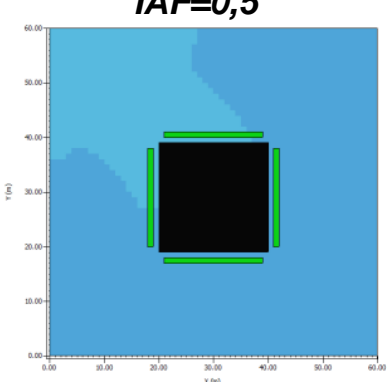

$I A F=2,0$

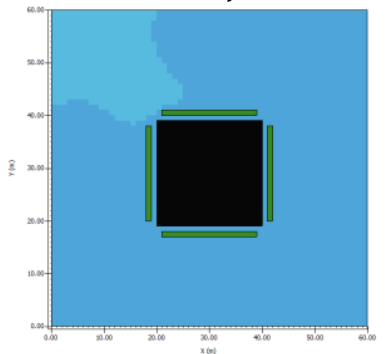

Air Temperature

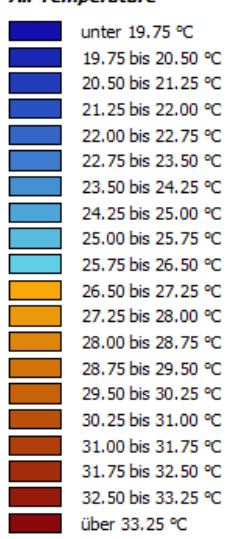

Min: $24.85^{\circ} \mathrm{C}$

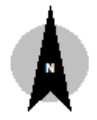

Figura 60 - Temperatura do ar simulada com umidade relativa do solo de $60 \%$ nos cenários sem vegetação e com vegetação para $I A F=0,5 \mathrm{~m}^{2} / 2, I A F=1,0 \mathrm{~m}^{2} / \mathrm{m}^{2}$ e $I A F=2,0 \mathrm{~m}^{2} / \mathrm{m}^{2}$ às $22 \mathrm{horas}$. 
Variando-se a umidade relativa do solo de $50 \%$ para $60 \%$, pode-se observar uma redução máxima de cerca de $0,36^{\circ} \mathrm{C}$ na temperatura do ar medida a $1,5 \mathrm{~m}$ do solo, para o mesmo IAF, conforme apresentado na Figura 61, abaixo.

$I A F=0,5$

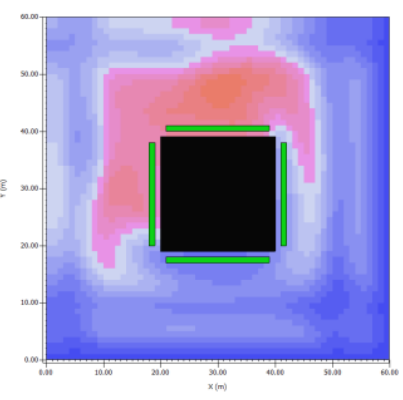

$I A F=1,0$

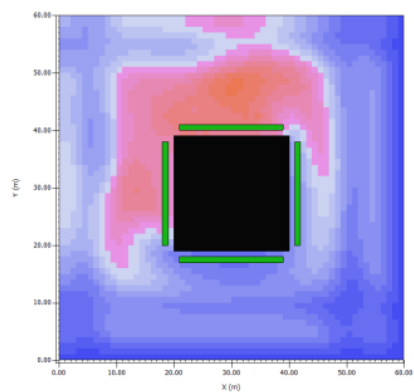

$I A F=2,0$

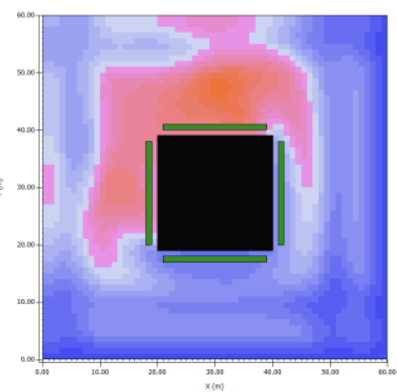

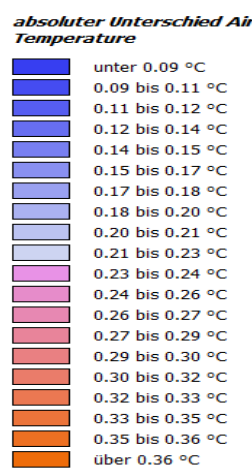

Min: $0.08^{\circ} \mathrm{C}$
Max: $0.37^{\circ} \mathrm{C}$

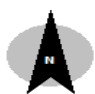

Figura 61 - Diferença de temperatura do ar para $I A F=0,5 \mathrm{~m}^{2} / \mathrm{m}^{2}, I A F=1,0 \mathrm{~m}^{2} / \mathrm{m}^{2}$ e $I A F=2,0 \mathrm{~m}^{2} / \mathrm{m}^{2}$ e variação da umidade relativa do solo $50 \%$ e $60 \%$ às $14 \mathrm{~h}, h=1,50 \mathrm{~m}$.

Na Figura 62 apresenta-se o efeito do incremento do índice de área foliar e da umidade do solo na variação da temperatura do ar entre 4:00h e 23:00h. Podese observar que o aumento no IAF e na umidade do solo são responsáveis pela diminuição na temperatura do ar em todo período, sendo a variação mais evidente no período da tarde onde são observados os picos de temperatura. Para esta análise foi considerado o ponto de maior diferença de temperatura observado nas figuras Figura 57 e 58.

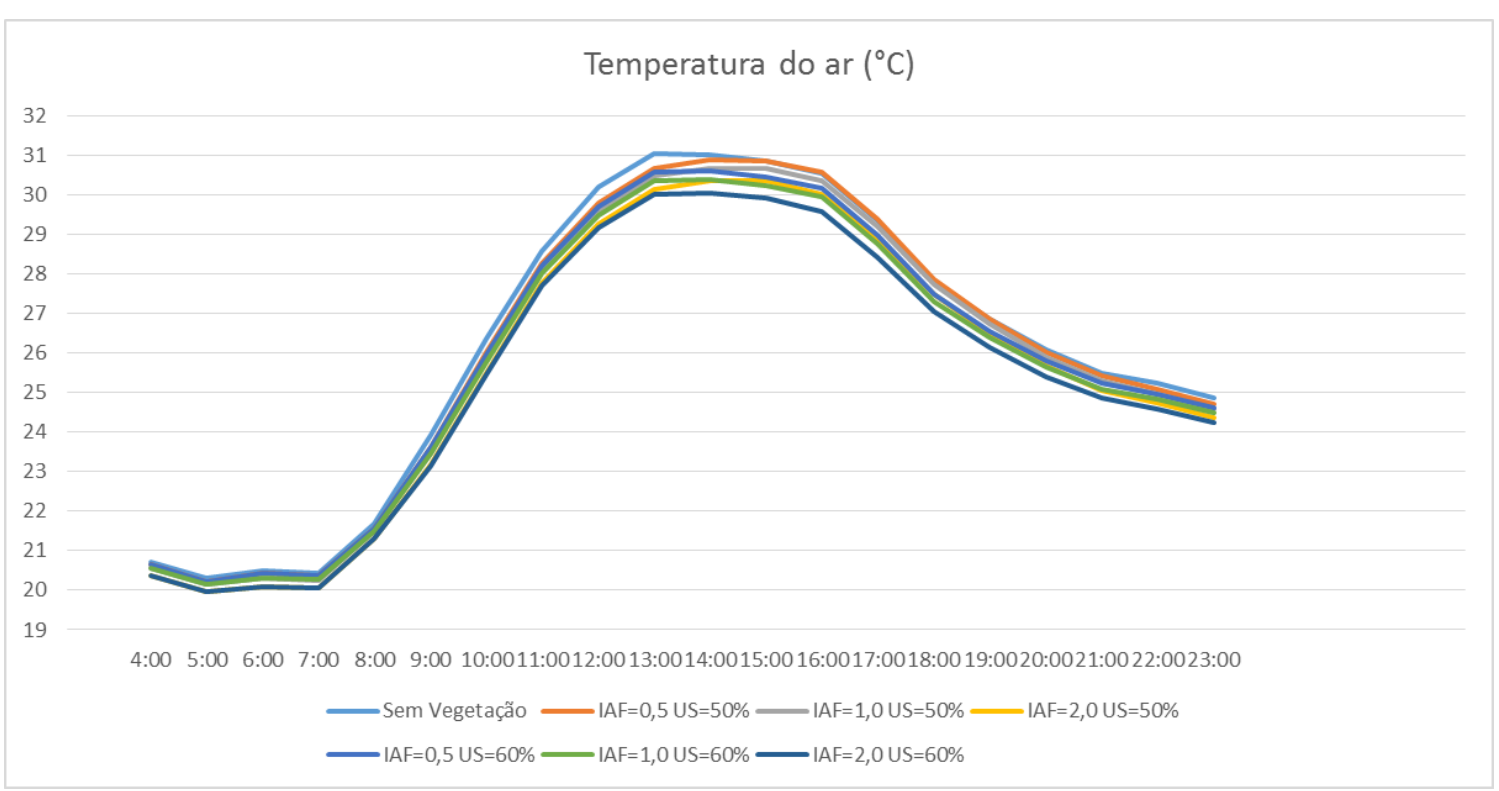

Figura 62 - Variação da temperatura do ar para $I A F I A F=0,5 \mathrm{~m}^{2} / \mathrm{m}^{2}, I A F=1,0 \mathrm{~m}^{2} / \mathrm{m}^{2} \mathrm{e}$ $I A F=2,0 \mathrm{~m}^{2} / \mathrm{m}^{2}$ e variação da umidade relativa do solo $50 \%$ e $60 \%$ 
Observando-se a Figura 63 pode-se notar que a temperatura de superfície no nível do solo é pontualmente afetada pela vegetação, chegando a uma redução de cerca de $15^{\circ} \mathrm{C}$ quando associada ao efeito do sombreamento.

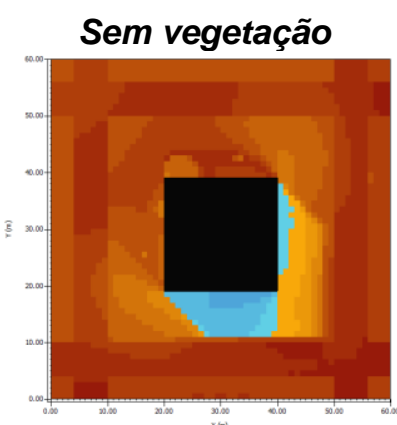

$I A F=1,0$

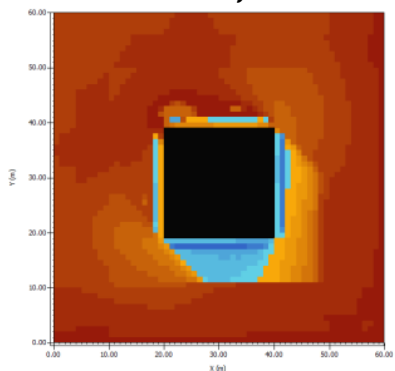

$I A F=0,5$

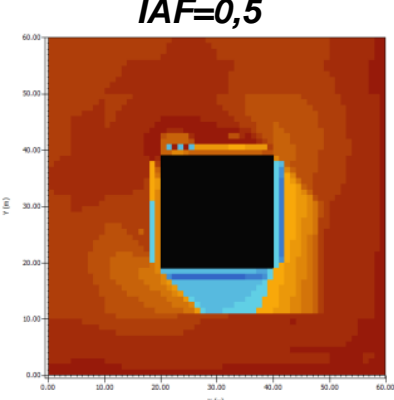

$I A F=2,0$

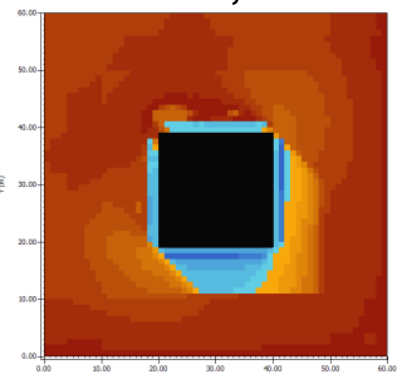

TSurface

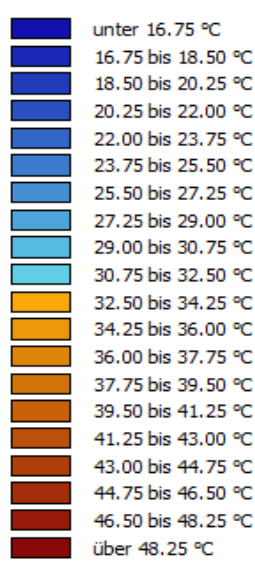

Min: $28.12^{\circ} \mathrm{C}$

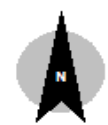

Figura 63 - Temperatura de superfície simulada com umidade relativa do solo de $50 \%$ nos cenários sem vegetação e com vegetação para $I A F=0,5 \mathrm{~m}^{2} / \mathrm{m}^{2}, I A F=1,0 \mathrm{~m}^{2} / \mathrm{m}^{2}$ e $I A F=2,0 \mathrm{~m}^{2} / \mathrm{m}^{2}$ às 14horas.

Na Figura 64, por sua vez, pode-se observar uma variação máxima de cerca de $25^{\circ} \mathrm{C}$ na temperatura de superfície, favorecida pelo efeito do sombreamento, com o incremento na umidade do solo e $\mathrm{IAF}=2,0 \mathrm{~m}^{2} / \mathrm{m}^{2}$.

Sem vegetação

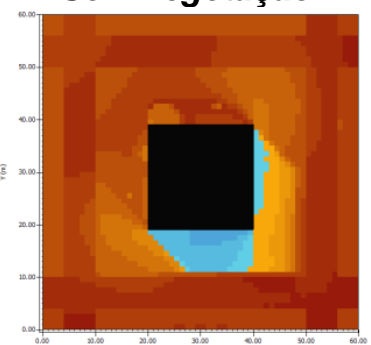

$I A F=1,0$

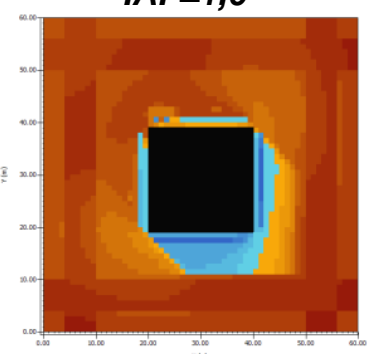

IAF $=0,5$

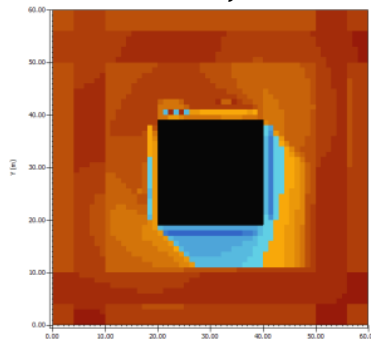

$I A F=2,0$

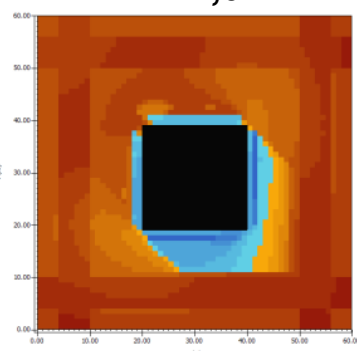

T Surface

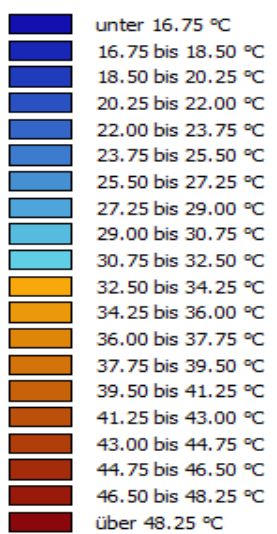
Min: $22.27^{\circ} \mathrm{C}$
Max: $47.31^{\circ} \mathrm{C}$

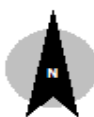

Figura 64 - Temperatura de superfície simulada com umidade relativa do solo de $60 \%$ e $I A F=0,5 \mathrm{~m}^{2} / \mathrm{m}^{2}, I A F=1,0 \mathrm{~m}^{2} / \mathrm{m}^{2}$ e $I A F=2,0 \mathrm{~m}^{2} / \mathrm{m}^{2}$ às 14 horas. 
Analisou-se também a influência da variação do índice de área foliar na umidade específica às $14 \mathrm{~h}$ para a umidade relativa do solo de $50 \%$ (Figura 65) e 60\% (Figura 66). Embora possam ser observados os efeitos da evapotranspiração a distâncias de até $4 \mathrm{~m}$ a sotavento, a variação máxima da umidade específica foi de $1,0 \mathrm{~g} / \mathrm{kg}$, à temperatura do $\operatorname{ar}$ de $26^{\circ} \mathrm{C}$.

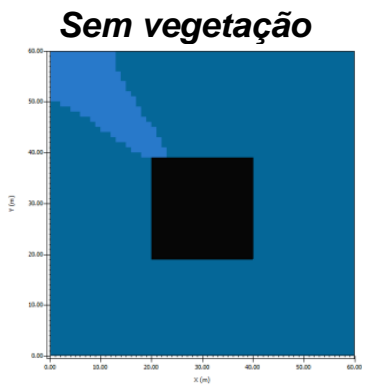

$I A F=1,0$

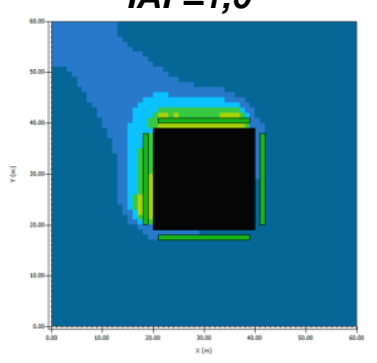

$I A F=0,5$

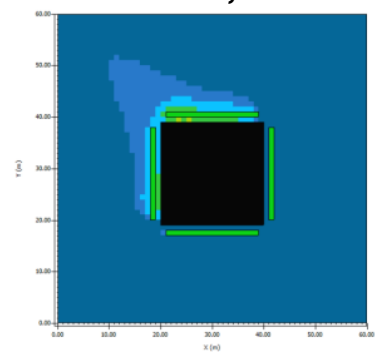

$I A F=2,0$

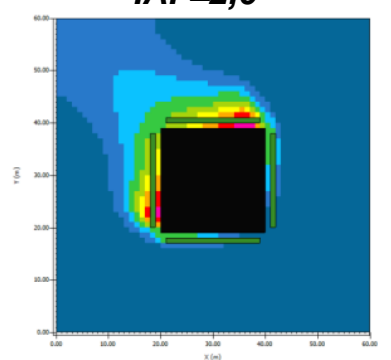

Spec. Humidity

unter $10.10 \mathrm{~g} / \mathrm{kg}$

10.10 bis $10.20 \mathrm{~g} / \mathrm{kg}$

10.20 bis $10.30 \mathrm{~g} / \mathrm{kg}$

10.30 bis $10.40 \mathrm{~g} / \mathrm{kg}$

10.40 bis $10.50 \mathrm{~g} / \mathrm{kg}$

10.50 bis $10.60 \mathrm{~g} / \mathrm{kg}$

10.60 bis $10.70 \mathrm{~g} / \mathrm{kg}$

10.70 bis $10.80 \mathrm{~g} / \mathrm{kg}$

10.80 bis $10.90 \mathrm{~g} / \mathrm{kg}$

über $10.90 \mathrm{~g} / \mathrm{kg}$

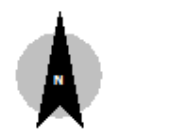

Figura 65 - Umidade específica para $I A F=0,5 \mathrm{~m}^{2} / \mathrm{m}^{2}, I A F=1,0 \mathrm{~m}^{2} / \mathrm{m}^{2}$ e $I A F=2,0 \mathrm{~m}^{2} / \mathrm{m}^{2}$ e umidade relativa do solo $50 \%$ às $14 \mathrm{~h}$.

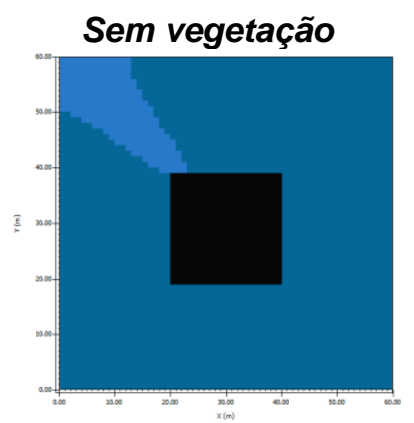

$I A F=1,0$

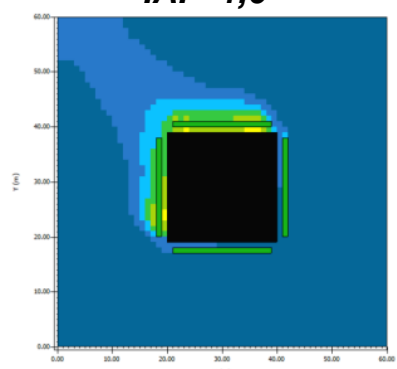

IAF $=0,5$

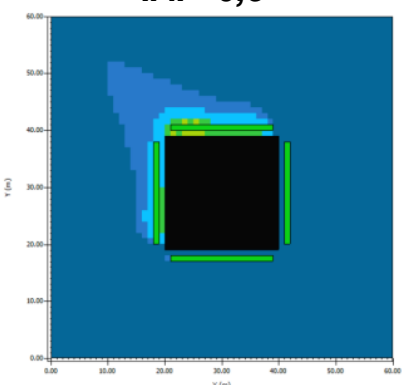

$I A F=2,0$

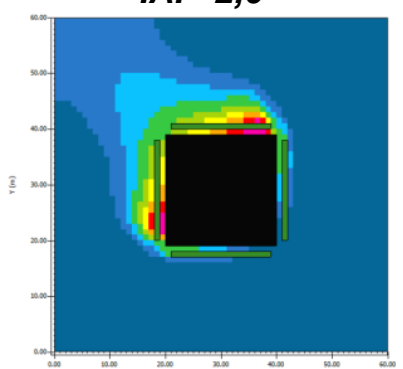

Spec. Humidity

$\square$ unter $10.10 \mathrm{~g} / \mathrm{kg}$ 10.10 bis $10.20 \mathrm{~g} / \mathrm{kg}$ 10.20 bis $10.30 \mathrm{~g} / \mathrm{kg}$ 10.30 bis $10.40 \mathrm{~g} / \mathrm{kg}$ 10.40 bis $10.50 \mathrm{~g} / \mathrm{kg}$ 10.50 bis $10.60 \mathrm{~g} / \mathrm{kg}$ 10.60 bis $10.70 \mathrm{~g} / \mathrm{k}$ 10.70 bis $10.80 \mathrm{~g} / \mathrm{kg}$ 10.80 bis $10.90 \mathrm{~g} / \mathrm{k}$ über $10.90 \mathrm{~g} / \mathrm{kg}$

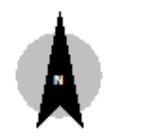

Figura 66 - Umidade específica para $I A F=0,5 m^{2} / m^{2}, I A F=1,0 m^{2} / m^{2}$ e $I A F=2,0 m^{2} / m^{2}$ e umidade relativa do solo $60 \%$ às $14 \mathrm{~h}$. 
Variando-se a umidade do solo para o mesmo IAF, pode-se concluir que o IAF é diretamente responsável pelo incremento na umidade específica no entorno imediato do edifício, proporcionado pela evapotranspiração das folhas. Porém, o aumento da umidade relativa do solo apresenta melhorias pouco significativas, entre $0,1 \%$ e $0,3 \%$, como observado na Figura 67.
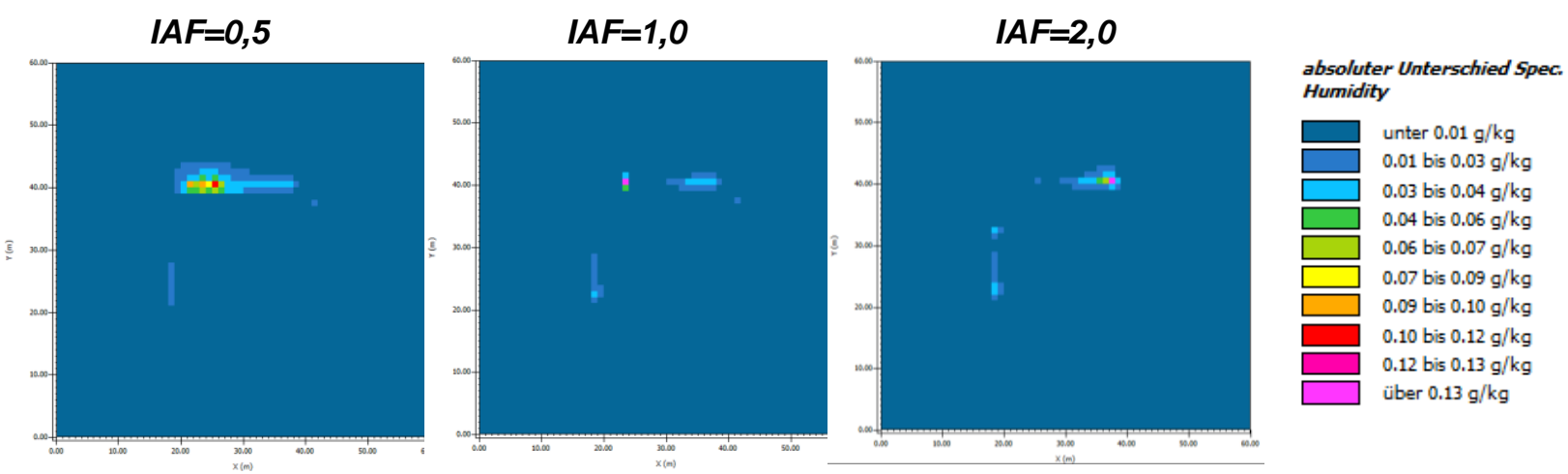

Figura 67 - Diferença de umidade específica para $I A F=0,5 \mathrm{~m}^{2} / \mathrm{m}^{2}, I A F=1,0 \mathrm{~m}^{2} / \mathrm{m}^{2}$ e $I A F=2,0 \mathrm{~m}^{2} / \mathrm{m}^{2}$ e variação da umidade relativa do solo $50 \%$ e $60 \%$ às $14 \mathrm{~h}$.

Na Figura 68 apresenta-se o efeito do incremento do índice de área foliar na variação da umidade específica entre 4:00h e 23:00h. Pode-se observar que 0 aumento no IAF é responsável pelo aumento na umidade específica no período entre 8:00h e 18:00h; a partir desse horário o modelo considera o fechamento dos estômatos e pode ser observada uma diminuição na umidade específica motivada por esse fator.

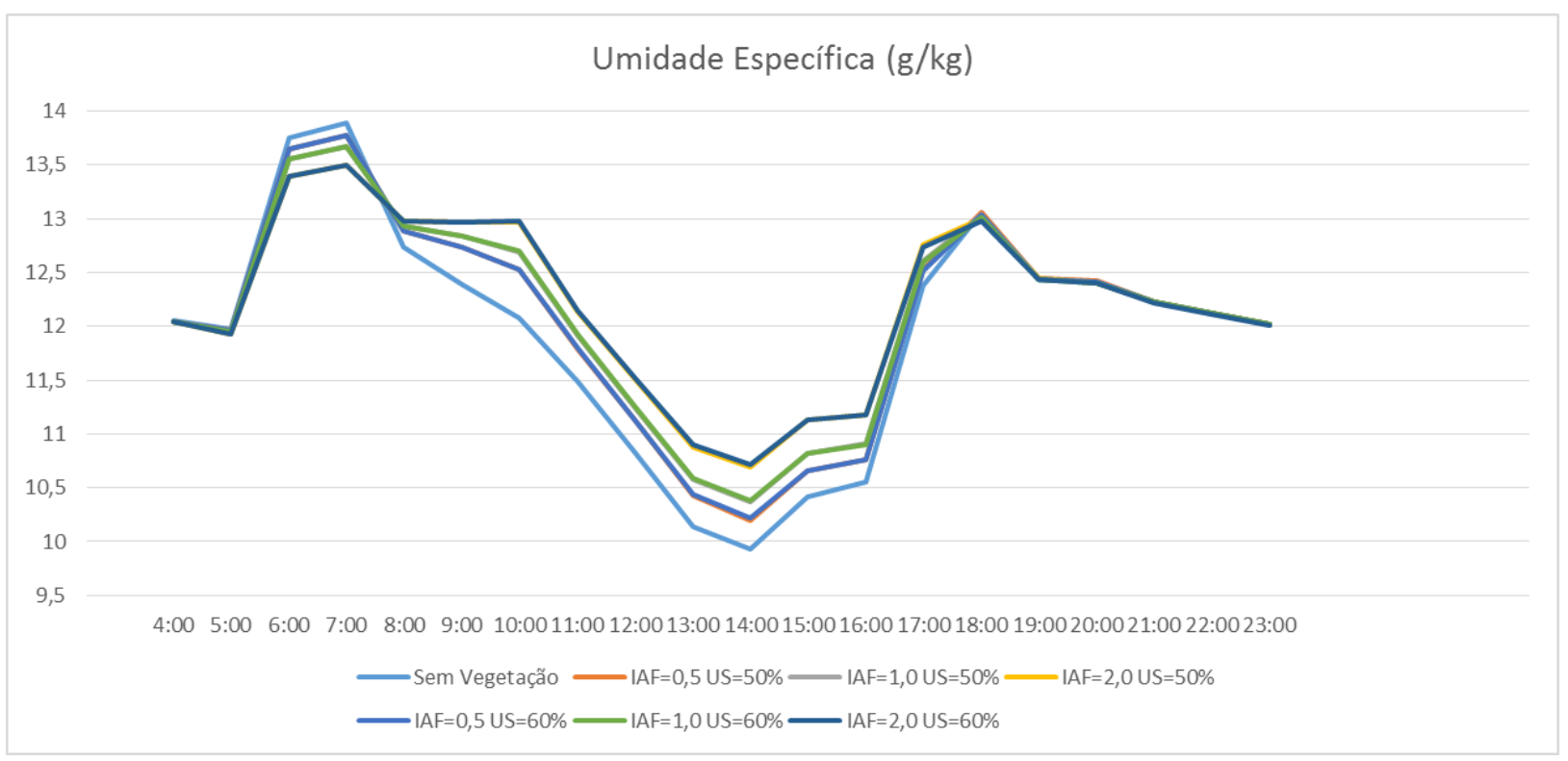

Figura 68 - Variação da umidade específica para $I A F=0,5 \mathrm{~m}^{2} / \mathrm{m}^{2}, I A F=1,0 \mathrm{~m}^{2} / \mathrm{m}^{2}$ e $I A F=2,0 \mathrm{~m}^{2} / \mathrm{m}^{2}$ e variação da umidade relativa do solo $50 \%$ e $60 \%$. 


\section{CONSIDERAÇÕES FINAIS E CONCLUSÕES}

O presente trabalho teve como objetivo quantificar o impacto das fachadas verdes no microclima urbano no nível do pedestre, considerando-se as variáveis temperatura e umidade do ar, temperatura de superfície e temperatura média radiante.

Em função da tipologia da vegetação escaladora atrelada à fachada do edifício, foi realizada a medição do DAF empiricamente, em trabalho experimental sugerido pelos autores do modelo, ao invés da medição do IAF como já foi feito em trabalhos anteriores do grupo, no dossel das árvores, com fotos hemisféricas ou analisador de dossel.

Dadas as restrições e recursos do ENVI-met, foram realizados testes de sensibilidade do modelo em relação às variáveis IAF $\left(0,5 \mathrm{~m}^{2} / \mathrm{m}^{2}, 1 \mathrm{~m}^{2} / \mathrm{m}^{2}\right.$ e $2 \mathrm{~m}^{2} / \mathrm{m}^{2}$ ) e umidade do solo (50\% e $60 \%$ ), para se avaliar o impacto da vegetação escaladora no microclima externo a um edifício, no seu entorno imediato. Pela primeira vez no grupo foi testado também um tamanho de grade de $1 \mathrm{mx} 1 \mathrm{~m}$, 0 menor já utilizado até agora, necessário à simulação dessa tipologia de vegetação, atrelada ao edifício.

As conclusões confirmam o efeito microclimático bastante localizado da parede verde do tipo escaladora e um comportamento distinto nos períodos diurno e noturno, como acontece em outras formas de inserção do verde em áreas urbanas, tal qual no experimento realizado por Wong et al., (2010), em Singapura, onde a diferença de temperatura mais significativa foi medida a 15 $\mathrm{cm}$ da superfície, diferença que foi se reduzindo à medida que se afastaram os sensores da superfície, tendo os sensores localizados a $60 \mathrm{~cm}$ apresentado uma diferença insignificante de temperatura do ar entre as superfícies estudadas.

À noite, na ausência da evapotranspiração estomática, o resfriamento é mais influenciado pela ventilação. Durante 0 dia percebe-se 0 efeito da evapotranspiração no ligeiro aumento da umidade do ar em 1,0g/kg, à temperatura do ar de $26^{\circ} \mathrm{C}$, e na diminuição da temperatura do ar, em ambos os casos quando comparadas ao cenário sem vegetação, sendo $0,17^{\circ} \mathrm{C}, 0,36^{\circ} \mathrm{C} \mathrm{e}$ 
$0,68^{\circ} \mathrm{C}$ com os incrementos sucessivos do IAF $\left(0,5 \mathrm{~m}^{2} / \mathrm{m}^{2}, 1 \mathrm{~m}^{2} / \mathrm{m}^{2}\right.$ e $\left.2 \mathrm{~m}^{2} / \mathrm{m}^{2}\right)$, para umidade do solo $50 \%$, às $14 \mathrm{~h}$, principalmente a sotavento.

O incremento na umidade do solo, de $50 \%$ para $60 \%$, resulta em aumento na evaporação do solo e aumento da evapotranspiração provocando redução máxima de cerca de $0,36^{\circ} \mathrm{C}$ na temperatura do ar a $1,5 \mathrm{~m}$ do solo, para o mesmo IAF.

Os efeitos da vegetação na temperatura radiante média são bastante localizados, tornando sua influência praticamente imperceptível no microclima exterior sob o efeito da radiação solar, apesar dos incrementos do IAF. O sombreamento provocado pela projeção da vegetação no solo resulta em pequena variação na TRM mesmo com o aumento na umidade relativa do solo, para o mesmo IAF, proporcionando redução de $0,01^{\circ} \mathrm{C}$ na TRM sob a vegetação,

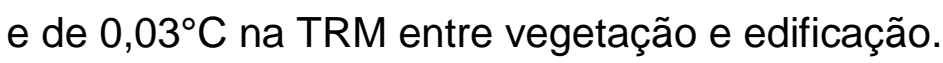

Os testes de sensibilidade mostram que o modelo é adequado para realização de estudos mais aprofundados, justificando o investimento em pesquisas futuras visando à validação dos dados com o recurso "full forcing" e à calibração entre dados microclimáticos medidos e simulados para paredes verdes em clima tropical e subtropical e à simulação microclimática de áreas urbanas com o uso dessa tecnologia.

Como o ENVI-met está em constante aperfeiçoamento, com a superação da impossibilidade atual de simulação do substrato na posição vertical, recomendase a realização de novas pesquisas incluindo a simulação de paredes vivas com substrato, representativas das tecnologias executadas na maioria das edificações em São Paulo, a calibração entre dados microclimáticos medidos e simulados para paredes verdes em clima tropical e subtropical e a simulação microclimática de áreas urbanas com o uso dessa tecnologia. 


\section{BIBLIOGRAFIA}

ALEXANDRI, E.; JONES, P. Developing a one-dimensional heat and mass transfer algorithm for describing the effect of green roofs on the built environment: Comparison with experimental results. Building and Environment, v. 42, n. 8, p. 2835-2849, 2007.

BESIR, A.B.; CUCE, E. Green roofs and facades: A comprehensive review. Renewable and Sustainable Energy Reviews 82 p. 915-939 (2018).

BOLTON, D. The Computation of Equivalent Potential Temperature. Monthly Weather Review, v. 108, p. 1046-1053, July, 1980.

BONAN,G. Ecological Climatology: Concepts and Applications, Cambridge University Press, New York, 2008.

BROWN, S. C.; LOMBARD, J.; WANG, K.; BYRNE, M. M.; TORO, M.; PLATERZYBERK, E.; FEASTER, D. J.; KARDYS, J.; NARDI, M. I.; PEREZ-GOMEZ, G.; PANTIN, H. M.; SZAPOCZNIK, J. Neighborhood greenness and chronic health conditions in medicare beneficiaries. American Journal of Preventive Medicine, v. $51, \quad$ n. $1, \quad$ p. $78-89, \quad 2016$. Disponível em: <http://dx.doi.org/10.1016/j.amepre.2016.02.008>.

BRUSE, M.; FLEER, H. Simulating surface-plant-air interactions inside urban environments with a three dimensional numerical model. Environment Modelling \& Software, 13(3-4): 373-384 (1998).

BRUSE, M.; RADTKE, U., Practical and theoretical investigation of the influence of façade greening on the distribution of heavy metals in urban streets. (1999). Disponível em < https://www.researchgate.net/publication/242131013> acesso em março, 2016.

BRUSE, M. ENVI-met implementation of the Jacobs A - $\mathrm{g}_{\mathrm{s}}$ Model to calculate the stomata conductance. (2004). Disponível em <http://envimet.com/documents/new a gs.pdf>. Acesso em novembro, 2016.

BRUSE, M. The Hitchhiker's Guide to ENVI-met. Disponível em: $<$ http://www.model.envi-met.com/hg2e/doku.php?id=files:downloadv4>. Acesso em março, 2016.

CAMERON, R. W. F.; TAYLOR, J. E.; EMMETT, M. R. What's "cool" in the world of green façades? How plant choice influences the cooling properties of green walls. Building and Environment, v. 73, p. 198-207, 2014. Disponível em: <http://dx.doi.org/10.1016/j.buildenv.2013.12.005>.

CAMERON, R. W. F.; TAYLOR, J.; EMMETT, M. A Hedera green façade Energy performance and saving under different maritime-temperate, winter 
weather conditions. Building and Environment, v. 92, p. 111-121, 2015. Disponível em: <http://dx.doi.org/10.1016/j.buildenv.2015.04.011>.

CHAROENKIT, S.; YIEMWATTANA, S. Living walls and their contribution to improved thermal comfort and carbon emission reduction: A review. Building and Environment, v. 105, p. 82-94, 2016. Disponível em: $<$ http://dx.doi.org/10.1016/j.buildenv.2016.05.031>.

COMA, J.; PÉREZ, G.; SOLÉ, C.; CASTELL, A.; CABEZA, L. F. New green facades as passive systems for energy savings on Buildings. Energy Procedia, v. $57, \quad$ p. 1851-1859, 2014. Disponível em: <http://dx.doi.org/10.1016/j.egypro.2014.10.049>.

COUTTS, A. M.; TAPPER, N. J.; BERINGER, J.; LOUGHNAN, M.; DEMUZERE, M. Watering our cities. Progress in Physical Geography, v. 37, n. 1, p. 2-28, 2013. <http://journals.sagepub.com/doi/10.1177/0309133312461032>.

COUTTS, A. M.; WHITE, E. C.; TAPPER, N. J.; BERINGER, J.; LIVESLEY, S. J. Erratum to: Temperature and human thermal comfort effects of street trees across three contrasting street canyon environments (Theor Appl Climatol, 10.1007/s00704-015-1409-y). Theoretical and Applied Climatology, v. 126, n. 34, p. 815, 2016.

CUGE - Center for Urban Greenery and Ecology. Disponível em: <https://www.cuge.com.sg/ >. Acesso em 20 de julho de 2015.

DAHANAYAKE, K. W. D. K. C.; CHOW, C. L. Studying the potential of energy saving through vertical greenery systems: Using EnergyPlus simulation program. Energy and Buildings, v. 138, p. 47-59, 2017. Disponível em: <http://dx.doi.org/10.1016/j.enbuild.2016.12.002>.

DAVIS, M. J. M.; RAMIREZ, F.; PÉREZ, M. E. More than just a Green Façade: Vertical Gardens as Active Air Conditioning Units. Procedia Engineering, v. 145, p. 1250-1257, 2016. Disponível em: <http://dx.doi.org/10.1016/j.proeng.2016.04.161>.

DAVIS, M. J. M.; RAMÍREZ, F.; VALLEJO, A. L. Vertical Gardens as Swamp Coolers. Procedia Engineering, v. 118, p. 145-159, 2015.

DERKZEN, M. L.; VAN TEEFFELEN, A. J. A.; VERBURG, P. H. Green infrastructure for urban climate adaptation: How do residents' views on climate impacts and green infrastructure shape adaptation preferences? Landscape and Urban Planning, v. 157, p. 106-130, 2017. Disponível em: <http://dx.doi.org/10.1016/j.landurbplan.2016.05.027>. 
DUARTE, D. O impacto da vegetação no microclima em cidades adensadas e seu papel na adaptação aos fenômenos de aquecimento urbano. Contribuições a uma abordagem interdisciplinar. Tese (Livre-docência), FAUUSP, 2015.

DUARTE, Denise. A inclusão de questões relacionadas aos microclimas urbanos nas regulamentações municipais no Brasil. In: Sinopses, Especial Tecnologia, São Paulo, FAUUSP, out. 2001, p.24-34.

DUARTE, D. Densidade e qualidade ambiental: o inevitável, o desejável e o possível. In: GALICIA, S.; FREIXANET, V. Hábitat Sustentable. México, D.F.: UAM Azcapolcotzalco, p.85-99, 2012.

DUARTE, D. O Clima Urbano e o Ambiente Construído. In: GONÇALVES, J.C.S.; BODE, K. (Org.). Edifício Ambiental. São Paulo: Oficina de Textos, 2015.

DUARTE, D. Vegetation and climate-sensitive public places. In: EMMANUEL, R. (Org.). Urban climate challenges in the Tropics: rethinking planning and design opportunities. Glasgow: Imperial College Press, 2016.

DUARTE, D.; SHINZATO, P.; GUSSON, C.S.; ALVES, C.A.; The impact of vegetation on urban microclimate to counterbalance built density in a subtropical changing climate. Urban Climate, n.14, 2015, p.224-239.

DUNNETT, N.; KINGSBURY, N. Planting Green Roofs and Living Walls. Portland/London: Timber Press, 2008.

EMMANUEL, M.R. An Urban Approach to Climate-Sensitive Design Strategies for the Tropics, New York, Taylor \& Francis, 2005.

EMMANUEL, R. (Org.). Urban climate challenges in the Tropics: rethinking planning and design opportunities. Glasgow: Imperial College Press, 2016.

ERELL, E.; PEARLMUTTER, D.; WILLIAMSON, T. Urban Microclimate: Designing the Spaces between Buildings. London: Earthscan, 2010.

ERELL, E.; Urban Greening and Microclimate Modification. Greening cities: Forms and Functions. p. 73-94, 2017.

FERREIRA, L.S. Manejo da Vegetação na cidade de São Paulo: Supressão e Compensação - $O$ caso do distrito da Vila Andrade. Tese (Mestrado em Arquitetura e Urbanismo), FAUUSP, 2012.

FERREIRA, L.S. Vegetation Management in São Paulo, Brazil: Clearing of Urban Vegetation and Environmental Compensation. In: Trees. People and the Built Environment II, 2015, Birmingham. Trees. People and the Built Environment II. Conference Proceedings, p. 32-42, 2015.

GILL, S. E.; HANDLEY, J. F.; ENNOS, A. R.; PAULEIT, S. Adapting cities for climate change: the role of the green infrastructure. Climate change and cities v. 33, n. 1, p. 115-133, 2007. 
GONÇALVES, J. et al. Manifesto Ambiental - Que cidade é essa que vamos construir com a LPUOS, a nova Lei de Parcelamento Uso e Ocupação do Solo da cidade de São Paulo 2016. Disponível em $<$ http://www.fau.usp.br/noticias/manifesto-ambiental-fauusp-joana.pdf>. Acesso em maio de 2016.

GUSSON, C. Efeito da densidade construída sobre o microclima urbano: construção de diferentes cenários e seus efeitos no microclima para a cidade de São Paulo, SP. Dissertação (Mestrado em Arquitetura e Urbanismo) Universidade de São Paulo, 2014.

HERMANN, B.M.; HADDAD, E.A. Muito Além do Jardim: Mercado Imobiliário e Amenidades Urbanas. TD Nereus, 04 (2003).

HOELSCHER, M. T.; NEHLS, T.; JÄNICKE, B.; WESSOLEK, G. Quantifying cooling effects of facade greening: Shading, transpiration and insulation. Energy and Buildings, v. 114, p. 283-290, 2016. Disponível em: <http://dx.doi.org/10.1016/j.enbuild.2015.06.047>.

HUANG, P. S.; TSAI, S. M.; LIN, H. C.; TSO, I. M. Do Biotope Area Factor values reflect ecological effectiveness of urban landscapes? A case study on university campuses in central Taiwan. Landscape and Urban Planning, v. 143, p. 143-149, 2015.

HUM, R.; LAI, P. Assessment of Biowalls: An overview of Plant- and Microbialbased indoor air purification system. Physical Plant Services, Queen's University p. 35, 2007.

HUNTER, A. M.; WILLIAMS, N. S. G.; RAYNER, J. P.; AYE, L.; HES, D.; LIVESLEY, S. J. Quantifying the thermal performance of green fa??ades: A critical review. Ecological Engineering, v. 63, p. 102-113, 2014. Disponível em: $<$ http://dx.doi.org/10.1016/j.ecoleng.2013.12.021>.

HUTTNER, S. Further development and application of the 3D microclimate simulation ENVI-met. PhD Thesis. Mainz University, Germany (2012).

HUTTNER, S.; BRUSE, M.; Numerical Modelling of The Urban Climate - A Preview on ENVI-met 4.0; The Seventh International Conference on Urban Climate ICUC-7, Yokohama, Japan, 2009.

JAAFAR, B.; SAID, I.; REBA, M. N. M.; RASIDI, M. H. Impact of Vertical Greenery System on Internal Building Corridors in the Tropic. Procedia - Social and Behavioral Sciences, v. 105, p. 558-568, 2013. Disponível em: $<$ http://linkinghub.elsevier.com/retrieve/pii/S1877042813044340> Acesso fevereiro 2018. 
JACOBS, C.M.J. Direct Impact of Atmospheric CO2 Enrichment on Regional Transpiration. Wageningen. Ph.D. Thesis. Agricultural University, Netherlands, 1994.

JUSUF, S. K.; WONG, N. H. Development of empirical models for an estate level air temperature prediction in Singapore. Proceedings of the Second International Conference on Countermeasures to Urban Heat Islands, p. 20, 2009.

KEELEY, M. The green area ratio: An urban site sustainability metric. Journal of Environmental Planning and Management, v. 54, n. 7, p. 937-958, 2011.

KÖHLER, M. Green facades-a view back and some visions. Urban Ecosystems, v. 11, n. 4, p. 423-436, 2008.

KONTOLEON, K. J.; EUMORFOPOULOU, E. A. The effect of the orientation and proportion of a plant-covered wall layer on the thermal performance of a building zone. Building and Environment, v. 45, n. 5, p. 1287-1303, 2010. Disponível em: $<$ http://dx.doi.org/10.1016/j.buildenv.2009.11.013>.

LALIC, B.; MIHAILOVIC, D. T. An empirical relation describing leaf-area density inside the forest for environmental modeling. J. Appl. Met., 2004.

LANDSCHAFT PLANEN \& BAUEN; BECKER GISEKE MOHREN RICHARD. The Biotope Area Factor as an Ecological Parameter- Principles for its determination and identification of the target - excerpt. Berlin, 1990. Disponível em

$<$ http://www.stadtentwicklung.berlin.de/umwelt/landschaftsplanung/bff/index en. shtml>. Acesso em maio de 2016.

LAU, K. K.-L.; LINDBERG, F.; RAYNER, D.; THORSSON, S. The effect of urban geometry on mean radiant temperature under future climate change: a study of three European cities. International Journal of Biometeorology, v. 59, n. 7, p. 799814, 2015. Disponível em: <http://link.springer.com/10.1007/s00484-014-0898$1>$.

LEE, S. H.; PARK, S. U. A vegetated urban canopy model for meteorological and environmental modelling. Boundary-Layer Meteorology, v. 126, n. 1, p. 73-102, 2008.

LEMONSU, A.; MASSON, V.; SHASHUA-BAR, L.; ERELL, E.; PEARLMUTTER, $D$. Inclusion of vegetation in the Town Energy Balance model for modelling urban green areas. Geoscientific Model Development, v. 5, n. 6, p. 1377-1393, 2012.

LIN, B. S.; LIN, Y. J. Cooling effect of shade trees with different characteristics in a subtropical urban park. HortScience, v. 45, n. 1, p. 83-86, 2010.

MALYS, L.; MUSY, M.; INARD, C. A hydrothermal model to assess the impact of 
green walls on urban microclimate and building energy consumption. Building and Environment, v. 73, p. 187-197, 2014. Disponível em: <http://dx.doi.org/10.1016/j.buildenv.2013.12.012>.

MADRE, F.; VERGNES, A.; MACHON, N.; CLERGEAU, P. Green roofs as habitats for wild plant species in urban landscapes: First insights from a largescale sampling. Landscape and Urban Planning 122 p. 100- 107 (2014).

MANGONE, G.; VAN DER LINDEN, K. Forest microclimates: Investigating the performance potential of vegetation at the building space scale. Building and Environment, v. 73, p. 12-23, 2014. Disponível em: <http://dx.doi.org/10.1016/j.buildenv.2013.11.012>.

MANSO, M.; CASTRO-GOMES, J. Green wall systems: A review of their characteristics. Renewable and Sustainable Energy Reviews, v. 41, p. 863-871, 2015. Disponível em: <http://dx.doi.org/10.1016/j.rser.2014.07.203>.

MASSON, Valéry. A physically-based scheme for the urban energy budget in atmospheric models. Boundary-Layer Meteorology, 94: 357-397, 2000.

MATHEUS, C.; CAETANO, F. D. N.; MORELLI, D. D. de O.; LABAKI, L. C. Desempenho térmico de envoltórias vegetadas em edificações no sudeste brasileiro. Ambiente Construído, v. 16, n. 1, p. 71-81, 2015.

MONTEIRO, L. ALUCCI, M. Proposal of an outdoor index: empirical verification in the subtropical climate. In: 27th Conference on Passive and Low Energy Architecture PLEA, 2011, Louvain-la-neuve, Belgium. Proceedings... Louvain-laneuve, July, 2011.

MORAKINYO, T. E.; LAM, Y. F. Simulation study on the impact of treeconfiguration, planting pattern and wind condition on street-canyon's microclimate and thermal comfort. Building and Environment, v. 103, p. 262-275, 2016. Disponível em: <http://dx.doi.org/10.1016/j.buildenv.2016.04.025>.

MORLEY, J. Functional Landscapes: Why Green Factor? Table of Contents. Landscape Architecture. Seattle 2008.

NIKOLOVA, I.; JANSSEN, S.; VOS, P.; VRANCKEN, K.; MISHRA, V.; BERGHMANS, P. Dispersion modelling of traffic induced ultrafine particles in a street canyon in Antwerp, Belgium and comparison with observations. Science of the Total Environment, v. 412-413, p. 336-343, 2011. Disponível em: <http://dx.doi.org/10.1016/j.scitotenv.2011.09.081>.

ONG, B. L. Green plot ratio: An ecological measure for architecture and urban planning. Landscape and Urban Planning, v. 63, n. 4, p. 197-211, 2003. 
OKE, T. R. Boundary Layer Climates. 2 ed. London; New York: Routledge; John Wiley \& Sons, 1987.

OKE, T. R. The energetic basis of the urban heat island. Quarterly Journal of the Royal Meteorology Society. v.108, n.455, p.1-24, jan.1982.

OKE, T.R. Boundary Layer Climates. 2ed. London: Routledge, 2002.

OKE, T.R. Initial guidance to obtain representative meteorological observations at urban sites. IOM Report № 81, WMO/TD № 1250. World Meteorological Organization. $\quad$ Geneva, $2006 . \quad$ Disponível em <http://www.wmo.int/pages/prog/www/IMOP/publications/IOM-81/IOM-81UrbanMetObs.pdf >. Acesso em novembro, 2016.

OKE, T.R.; MILLS, G.; CHRISTEN, A.; VOOGT, J.A. Urban Climates. Cambridge University Press, New York, 2017.

OSMOND P, SHARIFI, E. Guide To Urban Cooling Strategies. Low Carbon Living, $2017 . \quad$ Disponível em < http://www.lowcarbonlivingcrc.com.au/sites/all/files/publications_file_attachment s/crc_Icl_urban_cooling_guide_2017_web.pdf> Acesso em fevereiro 2018.

OTHMAN, A.R.; SAHIDIN, N. Vertical Greening Façade as Passive Approach in Sustainable Design. Procedia - Social and Behavioral Sciences, 222, p. 845 854, 2016.

PARAVANTIS, J.; SANTAMOURIS, M.; CARTALIS, C.; EFTHYMIOU, C.; KONTOULIS, N. Mortality Associated with High Ambient Temperatures, Heatwaves, and the Urban Heat Island in Athens, Greece. Sustainability, v. 9, n. 4, p. 606, 2017. Disponível em: <http://www.mdpi.com/2071-1050/9/4/606>.

PÉREZ, G.; RINCÓN, L.; VILA, A.; GONZÁLEZ, J. M.; CABEZA, L. F. Green vertical systems for buildings as passive systems for energy savings. Applied Energy, v. 88, n. 12, p. 4854-4859, 2011.

RILEY, B. The state of the art of living walls: Lessons learned. Building and Environment, v. 114, p. 219-232, 2017. Disponível em: <http://dx.doi.org/10.1016/j.buildenv.2016.12.016>.

SÃO PAULO (cidade). Atlas Ambiental do Município de São Paulo. Secretaria do Verde e do Meio Ambiente, Secretaria de Planejamento, Prefeitura Municipal de São Paulo, 2000. Disponível em <http://atlasambiental.prefeitura.sp.gov.br/>. Acesso em agosto 2016.

SÃO PAULO (cidade). Lei municipal no 16.402, de 22 de março de 2016. Disciplina o parcelamento, uso e ocupação do solo no Município de São Paulo. São Paulo: Diário Oficial da Cidade de São Paulo, ano 61, no 54. 2016. Disponível em 
$<$ http://www.docidadesp.imprensaoficial.com.br/NavegaEdicao.aspx?ClipID=2Q UAFFO7S38BLeER7VNEFPVLQBE\&PalavraChave $=16.402>$. Acesso em março de 2016.

SAFIKHANI, T.; ABDULLAH, A. M.; OSSEN, D. R.; BAHARVAND, M. A review of energy characteristic of vertical greenery systems. Renewable and Sustainable Energy Reviews, v. 40, p. 450-462, 2014.

SAILOR, D. J. A green roof model for building energy simulation programs. Energy and Buildings, v. 40, n. 8, p. 1466-1478, 2008.

SANTAMOURIS, M. Cooling the cities - A review of reflective and green roof mitigation technologies to fight heat island and improve comfort in urban environments. Solar Energy, v. 103, p. 682-703, 2014. Disponível em: $<$ http://dx.doi.org/10.1016/j.solener.2012.07.003>.

SHINZATO, P. Impacto da vegetação nos microclimas urbanos em função das interações solo-vegetação-atmosfera. Tese (Doutorado em Arquitetura e Urbanismo) - Universidade de São Paulo, 2014.

SHINZATO, Paula; SIMON, Helge; BRUSE, Michael; DUARTE, Denise. Simulation of microclimatic effects for green infrastructure in the city of São Paulo, Brazil. In: PLEA 2017 - Passive and Low Energy Architecture, 2017, Edinburgh. Proceedings. Edinburgh: NCEUB, 2017. v. 1. p. 153-160.

SOUZA, C. V. Políticas públicas para a inserção de vegetação nas cidades: compensação ambiental e indicadores de vegetação para o espaço público e privado. Iniciação Científica. Universidade de São Paulo, 2017.

SIMON, H. Modeling urban microclimate Development, implementation and evaluation of new and improved calculation methods for the urban microclimate model ENVI-met. PhD Thesis. Mainz University, Germany (2016).

SKELHORN, C. P.; LEVERMORE, G.; LINDLEY, S. J. Impacts on cooling energy consumption due to the $\mathrm{UHI}$ and vegetation changes in Manchester, UK. Energy and Buildings, v. 122, p. 150-159, 2016. Disponível em: <http://dx.doi.org/10.1016/j.enbuild.2016.01.035>.

SNIR, K.; PEARLMUTTER, D.; ERELL, E. The moderating effect of waterefficient ground cover vegetation on pedestrian thermal stress. Landscape and Urban Planning, v. 152, p. 1-12, 2016. Disponível em: <http://dx.doi.org/10.1016/j.landurbplan.2016.04.008>.

SOLCEROVA, A.; VAN DE VEN, F.; WANG, M.; RIJSDIJK, M.; VAN DE GIESEN, N. Do green roofs cool the air? Building and Environment, v. 111, p. 249-255, 2017. 
<http://dx.doi.org/10.1016/j.buildenv.2016.10.021>.

SPEAK, A. F.; ROTHWELL, J. J.; LINDLEY, S. J.; SMITH, C. L. Reduction of the urban cooling effects of an intensive green roof due to vegetation damage. Urban Climate, v. 3, p. 40-55, 2013. Disponível em: <http://dx.doi.org/10.1016/j.uclim.2013.01.001>.

SUSOROVA, I.; ANGULO, M.; BAHRAMI, P.; BRENT STEPHENS. A model of vegetated exterior facades for evaluation of wall thermal performance. Building and Environment, v. 67, p. 1-13, 2013. Disponível em: <http://dx.doi.org/10.1016/j.buildenv.2013.04.027>.

TAN, Z.; LAU, K. K. L.; NG, E. Urban tree design approaches for mitigating daytime urban heat island effects in a high-density urban environment. Energy and Buildings, v. 114, p. 265-274, 2016. Disponível em: <http://dx.doi.org/10.1016/j.enbuild.2015.06.031>.

THOM, J. K.; COUTTS, A. M.; BROADBENT, A. M.; TAPPER, N. J. The influence of increasing tree cover on mean radiant temperature across a mixed development suburb in Adelaide, Australia. Urban Forestry and Urban Greening, v. 20, p. 233-242, 2016. Disponível em: <http://dx.doi.org/10.1016/j.ufug.2016.08.016>.

VOOGT, J. How Researchers Measure Urban Heat Islands. Department of Geography, p. 34, 2007. Disponível em: <http://epa.gov/heatisland/resources/pdf/EPA_How_to_measure_a_UHI.pdf >.

WONG, I.; BALDWIN, A.N. Investigating the potential of applying vertical green walls to high-rise residential buildings for energy-saving in sub-tropical region. Building and Environment, 97, p.34-39, 2016.

WONG, N.H.; CHEN, Y. Tropical Urban Heat Islands: climate, buildings and greenery. New York: Taylor \& Francis, 2009.

WONG, N.H. Handbook on Green Walls in Singapore, Singapore: National Parks Board, 2009.

WONG, N.H. Handbook on Skyrise Greening in Singapore. Singapore: National Parks Board, 2002.

WONG, N.H.; JUSUF, S.K.; TAN, C.L. Integrated urban microclimate assessment method as a sustainable urban development and urban design tool, Landscape and Urban Planning, 100, p. 386-389, 2011.

WONG, N.H.; JUSUF, S.K. GIS-based greenery evaluation on campus master plan, Landscape and Urban Planning, 84, p. 166-182, 2008.

WONG, N. H.; KWANG TAN, A. Y.; CHEN, Y.; SEKAR, K.; TAN, P. Y.; CHAN, D.; CHIANG, K.; WONG, N. C. Thermal evaluation of vertical greenery systems 
for building walls. Building and Environment, v. 45, n. 3, p. 663-672, 2010. Disponível em: <http://dx.doi.org/10.1016/j.buildenv.2009.08.005>.

WONG, N.H.; TAN, A.Y.K.; TAN, P.Y.; WONG, N.C. Energy simulation on vertical greenery systems. Energy and Buildings, 41, p.1401-1408, 2009.

WONG, N.U. Evaluation of Vertical Greenery Systems for Building Walls, National University of Singapore, 2009. Disponível em: <http://www.bca.gov.sg/Researchlnnovation/others/VerticalGreenery.pdf>.

Acesso em julho, 2015.

WONG, N. H.; KWANG TAN, A. Y.; CHEN, Y.; SEKAR, K.; TAN, P. Y.; CHAN, D.; CHIANG, K.; WONG, N. C. Thermal evaluation of vertical greenery systems for building walls. Building and Environment, v. 45, n. 3, p. 663-672, 2010.

WOOD, A.; BAHRAMY, P.; SAFARIK, D. Green Walls in High-Rise Buildings: An output of the CTBUH Sustainability Working Group. Council on Tall Buildings and Urban Habitat, Chicago. 2014.

YANG, X.; ZHAO, L.; BRUSE, M.; MENG, Q. An integrated simulation method for building energy performance assessment in urban environments. Energy and Buildings, v. 54, p. 243-251, 2012. Disponível em: <http://dx.doi.org/10.1016/j.enbuild.2012.07.042>.

ZÖLCH, T.; MADERSPACHER, J.; WAMSLER, C.; PAULEIT, S. Using green infrastructure for urban climate-proofing: An evaluation of heat mitigation measures at the micro-scale. Urban Forestry and Urban Greening, v. 20, p. 305316, 2016. Disponível em: <http://dx.doi.org/10.1016/j.ufug.2016.09.011>. 


\section{APÊNDICE 1}

\section{Módulo de Visão Panorâmica ENVI-met}

O Módulo de Visão Panorâmica do modelo ENVI-met V4.2 está composto por atmosfera, solo, vegetação e ambiente construído, considerando as seguintes variáveis:

Ventilação: o ENVI-met está baseado em um modelo computacional tridimensional para simulação de dinâmica dos fluídos (CFD), utilizando o coeficiente de Reynolds, e as equações de Navier-Stokes para cada grade da área de simulação. Os efeitos da vegetação são considerados como forças de arrasto no campo de vento. Para a simulação detalhada da edificação, o fluxo de vento perto de cada segmento de fachada e telhado é calculado. $O$ fluxo de vento é atualizado em intervalos de tempo determinados, sendo que o ENVI-met suporta também um cálculo do fluxo em tempo real, porém esse recurso de cálculo exige computadores extremamente potentes.

Temperatura e umidade do ar: a temperatura e umidade específica do ar são determinadas por diferentes fontes e sumidouros de calor e vapor sensível dentro dos domínios do modelo. Baseados no cálculo tridimensional do campo de vento, advecção e difusão são simulados, sendo que a superfície do solo e a cobertura vegetal agem como fontes ou sumidouros de temperatura e umidade no modelo atmosférico, as envoltórias das edificações geralmente atuam como fontes de calor, mas também podem representar fontes de umidade no caso de paredes ou tetos com vegetação. O modelo ENVI-met não considera a transformação de fase entre água e vapor de água e vice-versa. Isto significa que a umidade relativa está sempre abaixo de 100\% (HUTTNER, 2012).

Turbulência: é calculada usando-se o intervalo E-epsilon ou K-epsilon 1.5, e duas equações de prognóstico são usadas para simular a distribuição de energia turbulenta. Os coeficientes de troca são calculados usando a relação de Prandtl \& Kolmogorov. 
Fluxos radiativos: o ENVI-met tem desenvolvido módulos de análise para modelar os fluxos de ondas curtas e radiação de onda longa para os microclimas. O esquema leva em conta o sombreamento proporcionado por geometrias complexas, reflexões por diferentes superfícies construídas e o efeito da vegetação em todos os fluxos radiativos.

O cálculo de radiação atmosférica é definido pelos coeficientes de absorção e emissão das diferentes camadas atmosféricas. Estes coeficientes dependem da espessura óptica da atmosfera, isto é, do número de aerossóis e da quantidade de vapor de água, dióxido de carbono, ozônio e outros gases de efeito estufa dentro da camada da atmosfera. Para um cálculo preciso dos fluxos radiativos, seria necessário conhecer a distribuição exata dos aerossóis e dos gases com efeito de estufa na atmosfera e explicar os seus espectros de emissão e absorção parcialmente sobrepostos. O ENVI-met usa uma aproximação muito mais simples que leva apenas o vapor de água em consideração (HUTTNER, 2012).

Dispersão de poluentes: o ENVI-Met permite considerar a dispersão e a deposição de até seis diferentes tipos de poluentes, incluindo partículas, gases passivos e gases reativos, sedimentação e deposição nas superfícies levando em conta também a vegetação assim como as reações fotoquímicas entre NO, $\mathrm{NO}_{2}$ e ozônio $\left(\mathrm{O}_{3}\right)$.

Temperatura do solo e de superfície: A temperatura da superfície e a temperatura do solo podem ser calculadas para solos naturais e artificiais, considerando materiais de vedação em profundidade de até $4 \mathrm{~m}$. Para cada camada da grade vertical pode-se escolher um material de solo ou vedação diferente de modo a simular diferentes estruturas de solos. A condutividade térmica dos solos naturais é calculada em relação ao teor real de água no solo.

Umidade do Solo: O ENVI-met baseia-se na Lei de Darcy para calcular a umidade do solo, levando em conta a absorção da água pelas raízes das plantas, sendo a simulação do balanço de água da superfície e do solo em profundidade um aspecto crucial na microclimatologia urbana, uma vez que solos úmidos 
podem atuar como dispositivos de arrefecimento e solos secos podem aquecer até mais do que o asfalto.

O modelo de solo calcula a temperatura e a umidade até uma profundidade de $1,75 \mathrm{~m}$. Para maiores profundidades, as variações diurnas de temperatura e umidade podem ser consideradas insignificantes no seu efeito sobre a atmosfera - pelo menos dentro das escalas de tempo normalmente simuladas com ENVImet ( $\leq 3$ dias), cada célula de grade horizontal tem um perfil de solo com 14 camadas que diferem em profundidade. A profundidade das camadas individuais aumenta de cima para baixo: enquanto as camadas superiores têm uma espessura de apenas $1 \mathrm{~cm}$, a camada mais baixa tem uma espessura de $50 \mathrm{~cm}$ (HUTTNER, 2012).

Disponibilidade de água para vegetação: através da simulação da umidade no solo, e do novo modelo de raízes em 3D, as trocas entre a vegetação e o solo podem ser calculadas pelo ENVI-met.

Geometria 3D das plantas: o modelo ENVI-met aceita simular plantas verticais simples e geometrias complexas de vegetação 3D como árvores de grande porte. Todas as plantas são tratadas como espécies individuais com um controle das trocas de calor e umidade levando em consideração também o estresse hídrico.

Temperatura das folhas: a temperatura das folhas é calculada através do balanço de energia da superfície foliar respeitando as condições fisiológicas e meteorológicas de plantas reais para cada grade da área de simulação. 0 modelo considera o estado de saúde da planta e a disponibilidade de água no solo, as taxas de transpiração usando um sofisticado modelo para simular o comportamento dos estômatos em resposta ao microclima, à disponibilidade de $\mathrm{CO}_{2}$ e ao nível de estresse hídrico.

Processos de troca com o ambiente: Um algoritmo complexo é usado para analisar o impacto da radiação solar nas plantas, considerando a projeção de sombra e as trocas de radiação de onda longa. 
Geometria 3D e elementos de sombreamento: Edificações e estruturas complexas podem ser construídas, desde que caibam na malha cúbica básica, permitindo inclusive a simulação de espaços semiabertos, como por exemplo, abrigos para pontos de ônibus ou estruturas exclusivas para sombreamento.

Detalhamento dos materiais construtivos: no modo de estrutura detalhada, 0 modelo permite atribuir tipos de materiais diferentes para cada superfície de parede e telhado. As paredes podem ser compostas por três camadas de diferentes materiais com propriedades distintas, tais como a transmitância, capacitância e condutividade térmicas.

Trocas de calor com a envoltória: Cada segmento de parede e telhado é representado por seu próprio modelo termodinâmico consistindo de sete pontos prognósticos de cálculo. A temperatura de cada ponto é atualizada continuamente em relação às variáveis meteorológicas para a envoltória considerada. O estado térmico dos pontos das paredes internas é calculado a partir das propriedades físicas atribuídas à envoltória com base na lei de condução de calor de Fourier, sendo o balanço térmico externo considerado não somente pelas variáveis meteorológicas como também pelas variações de refletividade e emissividade das edificações percebidas pelo ponto externo.

\section{Códigos internos do modelo ENVI-met V4.2:}

Esquema de discretização numérica: o modelo utiliza uma grade ortogonal Arakawa $C$-grid para representar o ambiente, incluindo a topografia em células como sendo preenchidas pelo solo; como consequência deste sistema só é permitida a representação de estruturas lineares e retangulares. Para a superfície do solo, a exposição e inclinação exatas são consideradas nos cálculos do balanço de energia; já em superfícies curvas e na construção de paredes e telhados os pontos a considerar devem ser aproximados na modelagem com a limitação das grades ortogonais. 
Linguagem de programação: o modelo é codificado em Object Pascal para Windows usando o Delphi.

Métodos numéricos: o ENVI-met usa o método de diferenças finitas para resolver o grande número de equações diferenciais parciais e outros aspectos do modelo. O esquema é parcialmente implícito, parcialmente explícito, dependendo do sistema subavaliado permitindo a redução de exigência computacional; um exemplo são cálculos de equações atmosféricas nas simulações de advecção e difusão onde é utilizado um esquema totalmente implícito, que permite ao modelo calcular durante intervalos de tempo relativamente grandes mantendo sua estabilidade numérica. Esse esquema permite que o modelo não necessite de computadores específicos para garantir seu desempenho.

Turbulência: o modelo computacional ENVI-Met utiliza duas equações do Modelo de energia cinética da turbulência (TKE) para prever a turbulência no ar.

A primeira equação descreve a distribuição da energia cinética $(E)$ do ar em função da produção, advecção, difusão e extinção a segunda equação é similar à primeira, mas descreve a taxa de dissipação de TKE, $\varepsilon$ ou eps.

Finalmente, o coeficiente de trocas turbulentas $K_{m}$ é dado por:

$$
K_{m}=c_{\mu} \frac{E^{2}}{\epsilon}
$$

O resultado da equação TKE- $\varepsilon$ para $K_{m}$ são usados como dados de entrada para o próximo ciclo de cálculo, havendo um ciclo de realimentação não linear entre o coeficiente de troca turbulenta e a equação de TKE- $\varepsilon$. Uma vez que $K_{m}$ começa a perder a estabilidade, o sistema de equações TKE- $\varepsilon$ ficará instável, deixando o $K_{m}$ ainda mais instável no próximo ciclo. Para tornar o modelo de cálculo da turbulência mais confiável, vários mecanismos foram introduzidos no ENVI-met:

- Cálculos cíclicos em duas etapas;

- Solucionador de problemas inteligente via relaxamento;

- Limitador de variação. 
Fluxo de onda longa: a radiação de onda longa absorvida é calculada da seguinte maneira: a fração de céu visível é calculada como fator de visão do céu (céu totalmente visível SVF =1), sendo que apenas os edifícios são contados no SVF.

Esta fração do céu visível (SVF) considera toda radiação de onda longa da atmosfera, da vegetação ou de ambos; a fração de céu obstruída (1-SVF) pode conter a radiação de onda longa de superfície ou emitida pelas paredes. A maior delas é a utilizada no cálculo.

Para a fração de céu visível proveniente do próprio céu e a parte que é proveniente da vegetação usa-se um fator de transmissão trans $_{\text {plant. }}$. Se não há plantas 0 trans $s_{\text {plant }=1}$, para vegetação de alta densidade 0 trans $s_{\text {plant }}=0$

Assim, obtém-se para a radiação de onda longa do céu visível ( $\left.L W_{\text {free }}\right)$ :

$$
L W_{\text {free }}=\text { trans }_{\text {plant }} * L W_{\text {sky }}+\left(1-\text { trans }_{\text {plant }}\right) * L W_{\text {plant }}
$$

Onde $L W_{\text {sky }}$ é a radiação atmosférica e $L W_{\text {plant }}$ é a radiação da vegetação.

Para céu obstruído $L W_{o b s t}$ :

$$
L W_{\text {obst }}=\max \left(q_{l w_{\_} e n v i}, q_{l w_{-} \text {surf }}\right)
$$

Onde, $q_{l w_{-} e n v i}$ é um valor médio das temperaturas das fachadas no modelo e

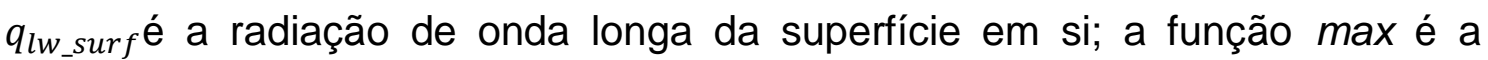
determinante para que o maior valor entre as duas seja o adotado. Finalmente, a radiação total de onda longa incidente é ponderada entre $L W_{\text {free }}$ e $L W_{o b s t}$, utilizando o STF:

$$
L W_{\text {total }}=S V F * L W_{\text {free }}+(1-S V F) * L W_{\text {obst }}
$$

Os valores encontrados nos arquivos de receptores de radiação proveniente da vegetação, da atmosfera e do entorno são baseados no seguinte cálculo: 


$$
\begin{gathered}
\text { vegetação }=S V F *\left(1-\operatorname{trans}_{\text {plant }}\right) * L W_{\text {plant }} \\
\text { atmosfera }=S V F * \text { trans }_{\text {plant }} * L W_{\text {sky }} \\
\text { entorno }=(1-S V F) * \max \left(q_{l w_{\text {envi }}}, q_{\text {lwsurf }}\right)
\end{gathered}
$$

Esses valores não correspondem à quantidade total de radiação de onda longa emitida, mas a quantidade de radiação que atinge a superfície de interesse.

Divergência no fluxo de onda longa: nas versões anteriores ao ENVI-met V 3.1, o efeito de divergência no fluxo de onda longa levou em conta apenas as superfícies de solo e folha, ignorando o ar; essas trocas eram consideradas demasiadamente complexas para serem incluídas no modelo, pois os fluxos de ondas longas dentro de ambientes urbanos são muito complexos não sendo conduzidos apenas por fluxos verticais, mas também por fluxos horizontais.

No entanto, as aplicações recentes têm indicado que o modelo computacional ENVI-met tem tendência a subestimar a dinâmica da amplitude de temperatura diurna. As razões possíveis para que isso ocorra podem ser atribuídas aos seguintes fatores: simulando no ENVI-met com configurações "não forçadas" ou com o modelo não aninhado adequadamente, muitas vezes a dinâmica da temperatura do ar é subestimada porque os efeitos regionais são diferentes do que os considerados pelo modelo, ou não estão incluídos nas equações de temperatura os fenômenos de aquecimento e arrefecimento de camadas de ar, devido a uma divergência da radiação de ondas longas verticais.

Não se sabe exatamente o tamanho do impacto se considerado apenas o segundo aspecto sobre a dinâmica da temperatura do ar; por este motivo existem diversos mecanismos de correção no modelo, sendo que o controle de divergência do fluxo de onda longa é calculado através de uma relação fonte/sumidouro adicional na equação prognóstica da temperatura do ar. 
As equações complexas resultantes e integrações verticais podem ser significativamente simplificadas, assumindo-se uma isotropia térmica atmosférica. Neste caso, são necessárias apenas três temperaturas de referência: a temperatura da camada de ar em questão, a temperatura da superfície do solo subjacente e a temperatura da atmosfera superior. Dessa maneira, a questão da divergência do fluxo de onda longa pode ser transformada em uma questão de divergência de emissividades, que podem ser facilmente resolvidas conhecendo-se a umidade das camadas de ar que compõem o sistema a simular.
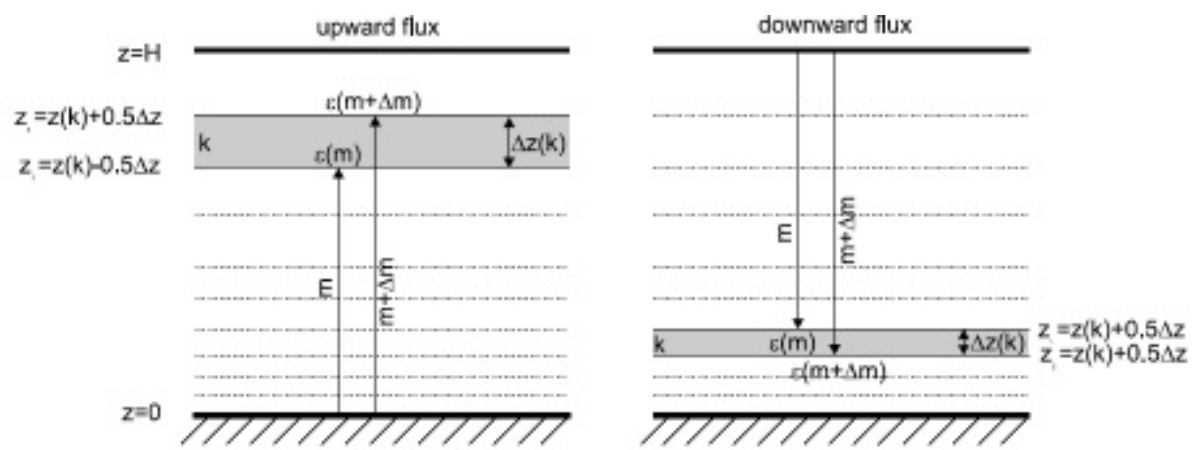

Figura 69: Integração vertical entre umidade e fluxos de onda-longa Disponível em <http://www.model.envi-met.com > acesso em outubro de 2016.

A Figura 69 mostra como as camadas atmosféricas são usadas para calcular a emissividade das camadas individuais no modelo computacional ENVI-met, onde $m$ é a umidade na respectiva atmosfera sem considerar a camada analisada e $M+$ é a umidade $\Delta z$ com a camada analisada. A emissividade resultante pode ser calculada a partir de equações empíricas.

Esta formulação leva em conta apenas implicitamente os efeitos dos fluxos de ondas longas horizontais através de temperaturas do ar e de superfície, bem como os efeitos da vegetação.

Bio-met: Bio-met é um pós-processamento para cálculo de índices de conforto térmico baseados nos dados do modelo simulado que interage diretamente com os resultados dos dados de saída do ENVI-met, permitindo que o usuário possa 
definir interativamente os parâmetros pessoais e o índice térmico de conforto desejado.

Na versão 1.0 do Bio-met é possível calcular o índice de Voto Médio Estimado (PMV/PPD), Temperatura Equivalente Fisiológica - $\mathrm{PET}^{32}$, e o Índice Termoclimático Universal - UTCI. Os índices variam em seu nível de complexidade e, portanto, em seu tempo de cálculo; enquanto o UTCl é uma regressão com base rápida, PMV requer uma solução integrada de balanço de energia e o PET necessita de um resultado embasado nas duas equações, necessitando de muito mais tempo e recurso computacional. Quando comparada a versões mais antigas do ENVI-met, essa ferramenta permite efetuar os cálculos de índices de conforto térmico como um pós-processamento modificando configurações pessoais sem a necessidade de reiniciar todo processo de cálculo.

${ }^{32}$ Recursos disponíveis apenas para a licença profissional do ENVI-met, disponível para este trabalho. 


\section{APÊNDICE 2}

Nos últimos anos, a aplicação de conceitos ecológicos em projetos paisagísticos para aumentar a biodiversidade nas áreas urbanas tornou-se uma estratégia importante em todo o mundo. Este trabalho pretende apresentar um panorama global de iniciativas que visam buscar melhores condições de conforto e uma maior inserção de vegetação no ambiente urbano. Aqui são consideradas inciativas internacionais que incluem especificamente indicadores de vegetação para as seguintes cidades: Berlim, Alemanha (Biotope Area Factor); Seattle, EUA (Seattle Green Factor); Malmö, Suécia (Green Space Factor \& Green Points System); Singapura (Green Plot Ratio) e São Paulo (Quota Ambiental).

\section{Biotope Area Factor - Berlim}

Em Berlim, a implantação do Biotope Area Factor - BAF, iniciada em 1994, se estabelece principalmente em planos paisagísticos como um indicador de planejamento ambiental.

Segundo o Departamento de Ambiente e Proteção do Clima de Berlim, ${ }^{33}$ o BAF formulou metas básicas e medidas para promoção de desenvolvimento com qualidade e respeito ao ecossistema, proteção aos biótopos ${ }^{34}$ e espécies, à aparência da paisagem e às áreas de uso recreacional.

Com abordagens diferenciadas por regiões da cidade, a portaria que determina o uso do BAF traz uma abordagem particular para assegurar áreas com "qualidades verdes" na região central da cidade, onde a alta densidade construída e os grandes impactos ambientais demonstraram um alto grau de impermeabilização do solo, inadequada destinação das águas pluviais, excesso de aquecimento e baixas taxas de umidade do ar, aliadas a uma constante

\footnotetext{
33 Disponível em:

http://www.stadtentwicklung.berlin.de/umwelt/landschaftsplanung/bff/index en.shtml, Acesso em janeiro 2017.

${ }^{34} \mathrm{Em}$ Ecologia, um biótopo ou ecótopo é uma região que apresenta regularidade nas condições ambientais e nas populações animais e vegetais. Corresponde à menor parcela de um habitat que é possível discernir geograficamente.
} 
redução nos habitats de plantas e animais. Fora destas áreas, o BAF é voluntário e pode ser usado como diretriz para encorajar medidas ambientais a serem incorporadas quando forem propostas mudanças nos edifícios existentes.

De acordo com o programa para a proteção da paisagem e das espécies, uma meta importante do desenvolvimento urbano em Berlim é a redução do impacto ambiental no centro da cidade. Melhorar a funcionalidade do ecossistema, promover o desenvolvimento dos biótopos, mantendo o uso atual da terra, são iniciativas fundamentais para este esforço.

O BAF determina a porção da área destinada à implantação de vegetação, assumindo outras funções para o ecossistema local, contribuindo para a padronização e colocação em termos concretos das seguintes metas de qualidade ambiental:

- Salvaguardar e melhorar o microclima e a qualidade do ar;

- Estimular e garantir a manutenção da permeabilidade do solo e o balanço hídrico;

- Criação e melhoria do habitat para plantas e animais;

- Melhorar o entorno de áreas residenciais.

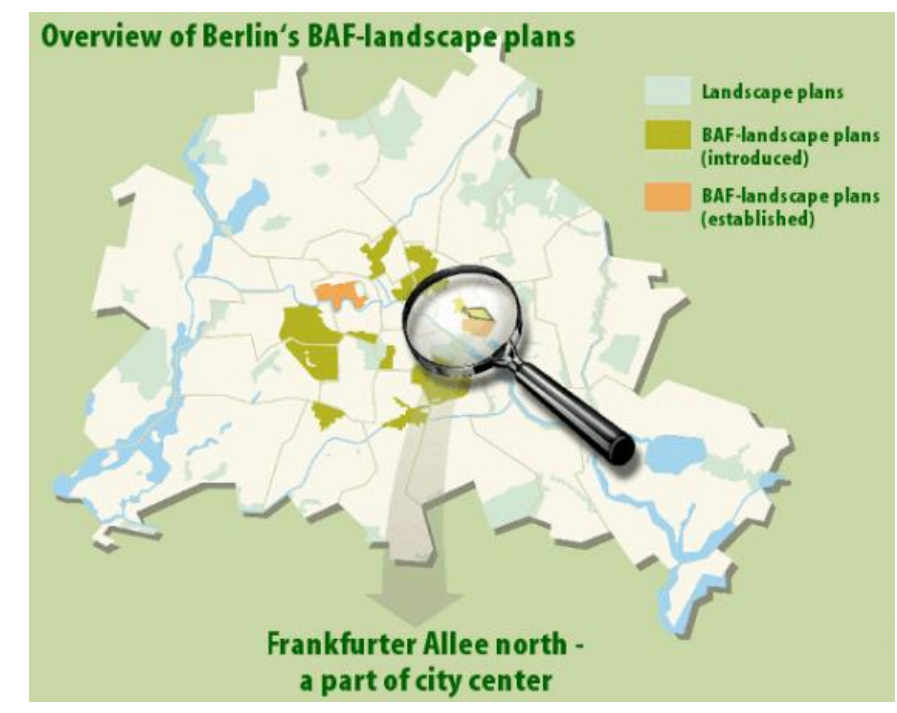

Figura 70 - Visão geral dos planos de paisagem de Berlim. Disponível em: <http://www.stadtentwicklung.berlin.de/umwelt/landschaftsplanung/bff/index_en.shtml> Acesso em janeiro de 2017. 

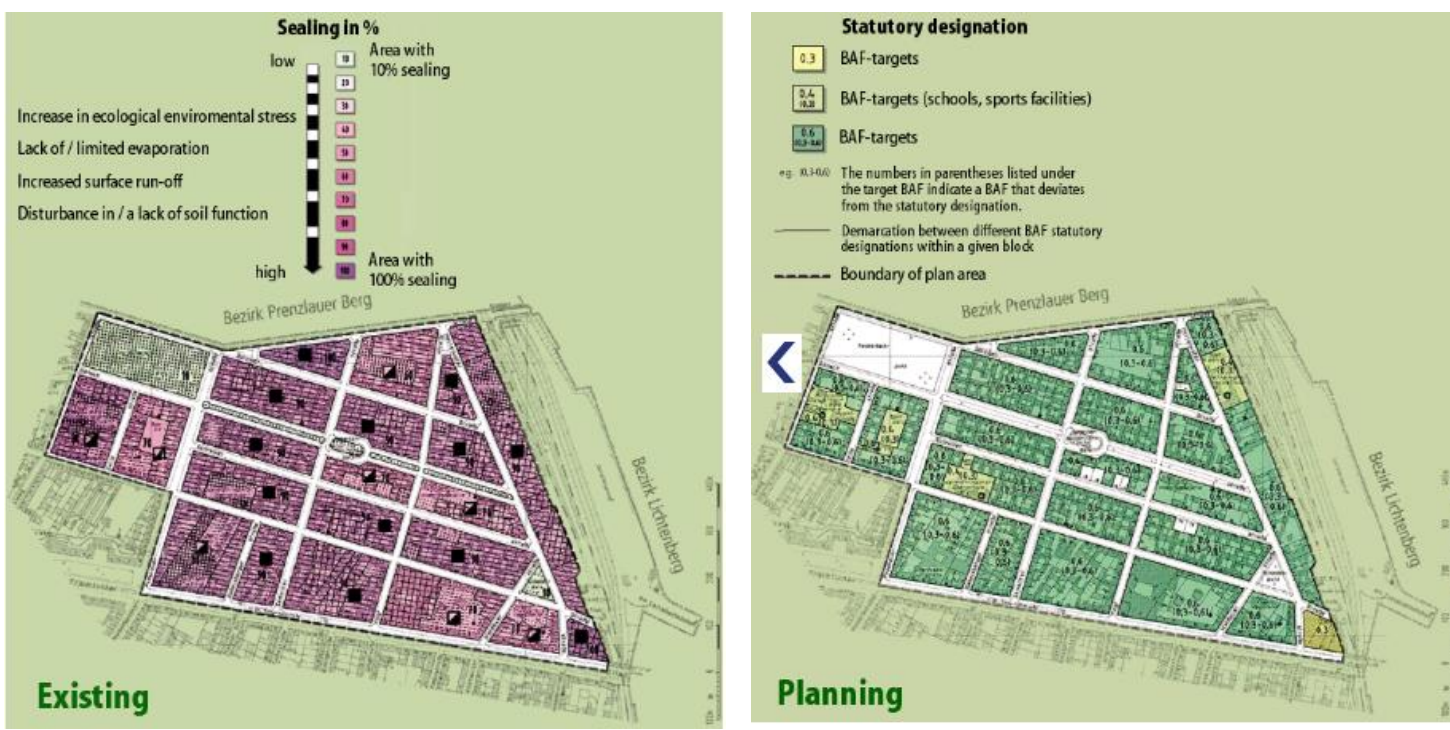

Figura 71 - Planos de paisagem de Berlim, situações existente e pretendida. Disponível em: $<$ <ttp://www.stadtentwicklung.berlin.de/umwelt/landschaftsplanung/bff/index_en.shtml> Acesso em janeiro 2017.

Áreas de Aplicação:

BAF pretende abranger os diversos usos urbanos: residencial, comercial e industrial, determinando áreas mínimas de vegetação a serem incorporadas em edificações a reformar e novas edificações, em quaisquer espaços em potencial tais como pátios, paredes e telhados verdes.

Os valores a serem adotados estão listados na Tabela 8 abaixo e são aplicáveis a diversas estruturas e usos:

Tabela 8 - Tabelas de valores aplicáveis para definição das áreas verdes necessárias ao atendimento do BAF.

\begin{tabular}{|c|c|c|}
\hline \multicolumn{3}{|c|}{ Objetivos do BAF } \\
\hline \multicolumn{2}{|c|}{$\begin{array}{c}\text { Edificações a Reformar e Ampliar } \\
\text { Criação de um espaço residencial extra ou ampliação do } \\
\text { nível de cobertura (DC) }\end{array}$} & \multirow[t]{2}{*}{ Novas Edificações } \\
\hline DC & BAF & \\
\hline \multicolumn{3}{|c|}{$\begin{array}{l}\text { Unidades Residenciais (uso residencial ou misto sem a utilização do espaço aberto para fin } \\
\text { comerciais) }\end{array}$} \\
\hline Até 0,37 & 0,60 & 0,60 \\
\hline
\end{tabular}




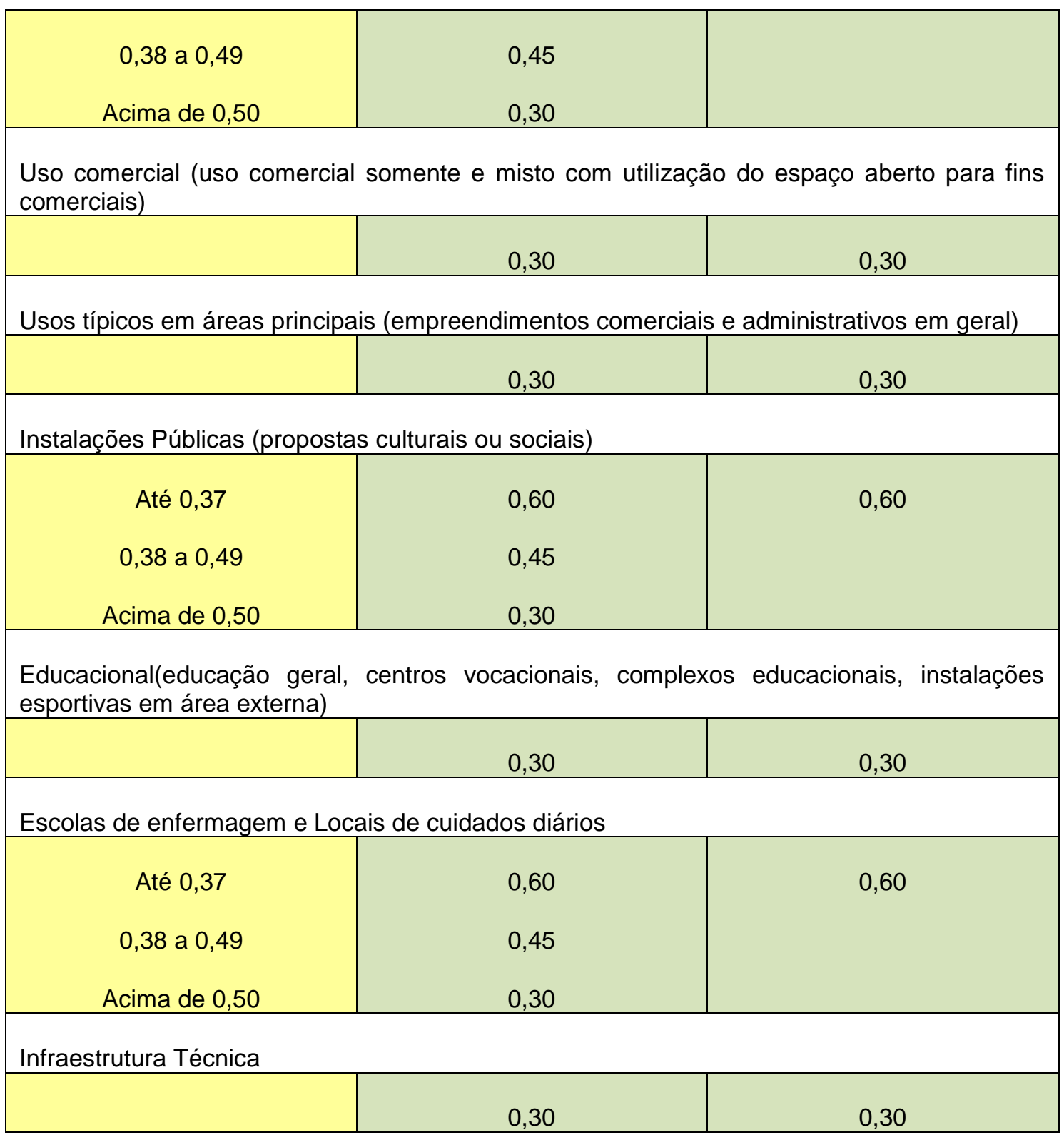

Disponível em:

$<h t t p: / / w w w . s t a d t e n t w i c k l u n g . b e r l i n . d e / u m w e l t / l a n d s c h a f t s p l a n u n g /$ bff/index_en.shtml> Acesso em janeiro 2017.

\section{Cálculo do BAF}

O BAF expressa a relação entre a área de vegetação realmente eficaz e a área total do terreno:

$$
B A F=\frac{\text { área de superfície ef etivamente ecológica }}{\text { área total do terreno }}
$$


Neste cálculo, as partes individuais de um lote são ponderadas de acordo com o seu "valor ecológico".

Tabela 9 - Coeficientes de ponderação para cada tipo de superfície.

\begin{tabular}{|c|c|c|}
\hline \multicolumn{2}{|c|}{$\begin{array}{l}\text { Fator de ponderação por } \mathrm{m}^{2} \text { de tipo de } \\
\text { superfície }\end{array}$} & Descrição do tipo de Superfície \\
\hline & $\begin{array}{l}\text { Superfície selada } \\
\qquad 0,0\end{array}$ & $\begin{array}{l}\text { A superfície é impermeável ao ar e à } \\
\text { água, não apresentando crescimento } \\
\text { de nenhum tipo de vegetação. } \\
\text { (Ex. concreto, asfalto, lajes). }\end{array}$ \\
\hline & $\begin{array}{l}\text { Superfície parcialmente } \\
\text { selada } \\
0,30\end{array}$ & $\begin{array}{l}\text { A superfície é permeável ao ar e à } \\
\text { água, não permitindo o crescimento } \\
\text { de nenhum tipo de vegetação. } \\
\text { (Ex. tijolo de clínquer, pavimentação } \\
\text { em mosaicos, placas sobre sub-base } \\
\text { de areia ou cascalho). }\end{array}$ \\
\hline & $\begin{array}{l}\text { Superfícies semi-porosas } \\
\qquad 0,50\end{array}$ & $\begin{array}{l}\text { A superfície é permeável ao ar e à } \\
\text { água, permitindo o crescimento de } \\
\text { vegetação. } \\
\text { (Ex. cascalho, com cobertura de relva, } \\
\text { pavimentação em blocos de madeira, } \\
\text { tijolo do tipo favo-de-mel com } \\
\text { vegetação). }\end{array}$ \\
\hline & $\begin{array}{c}\text { Superfícies com vegetação } \\
\text { desconectadas do solo } \\
\text { natural }\end{array}$ & $\begin{array}{l}\text { Superfícies com vegetação em } \\
\text { coberturas com menos de } 0,80 \mathrm{~m} \text { de } \\
\text { profundidade de solo. }\end{array}$ \\
\hline & 0,5 & \\
\hline & $\begin{array}{c}\text { Superfícies com vegetação } \\
\text { desconectadas do solo } \\
\text { natural }\end{array}$ & $\begin{array}{l}\text { Superfícies com vegetação } \\
\text { desconectadas do solo natural com } \\
\text { mais de } 0,80 \mathrm{~m} \text { de profundidade de } \\
\text { solo. }\end{array}$ \\
\hline & 0,7 & \\
\hline
\end{tabular}




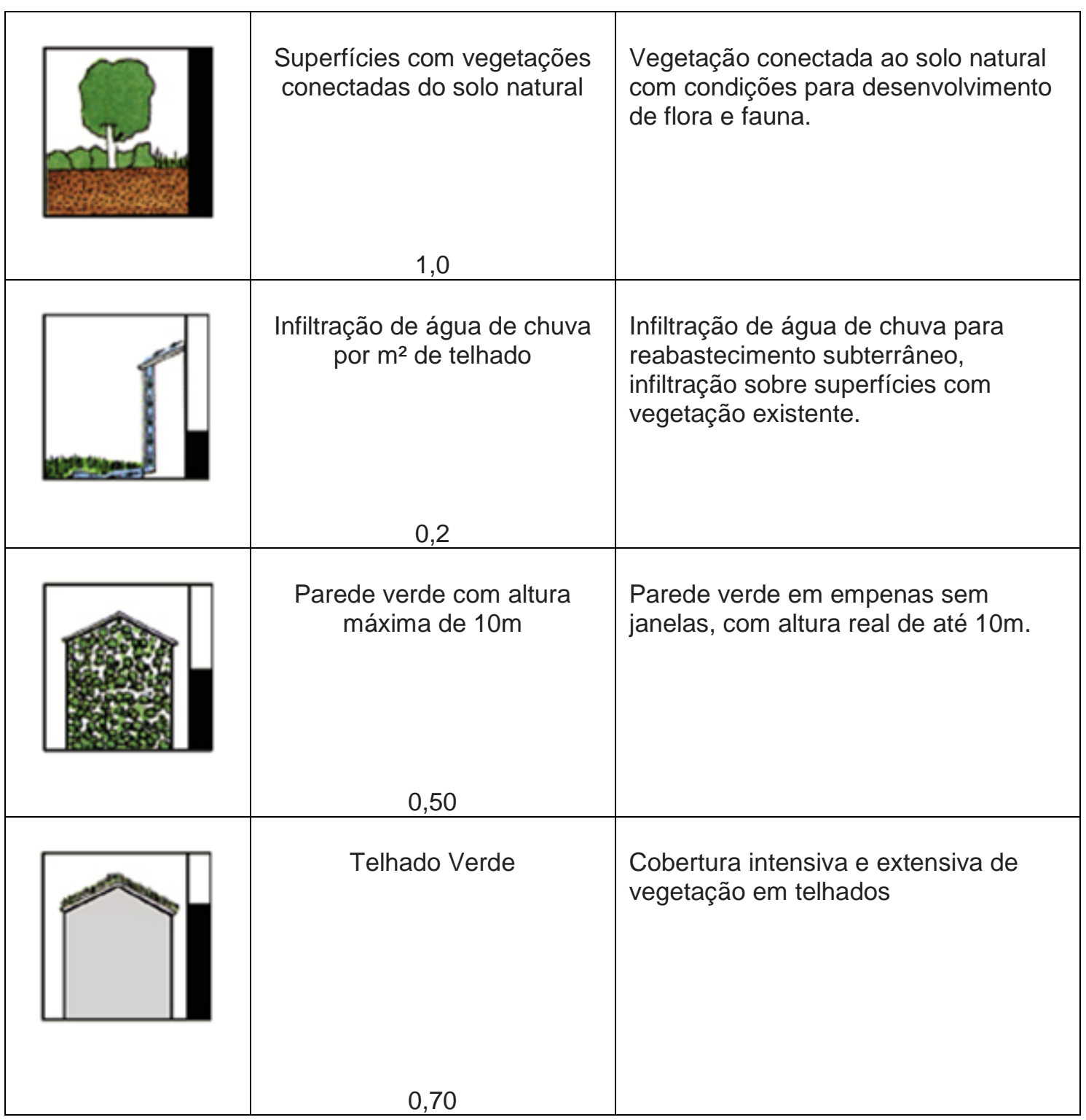

Fonte: www.stadtentwicklung.berlin.de. Acesso em janeiro 2017.

\section{Exemplo de cálculo:}

Cada lote pode ser concebido de várias maneiras. Em princípio, as medidas que levam a uma expansão da área de vegetação no terreno têm prioridade. Só então se consideram as possibilidades adicionais, tais como a substituição de asfalto com outras superfícies a serem utilizadas.

Terreno

$479 m^{2}$

Área Construída

$279 m^{2}$

Área não construída $\quad 200 \mathrm{~m}^{2}$ 
Índice de ocupação $\quad 0,59$

Pátio coberto principalmente com asfalto. Há cascalho com cobertura de grama na periferia, e a árvore está em um leito do solo que mede $1 \mathrm{~m}^{2}$.

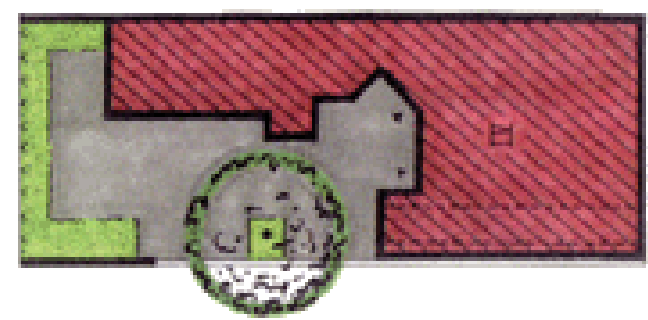

Figura 72 - Terreno modelo utilizado para cálculo do BAF, situação inicial. Fonte: www.stadtentwicklung.berlin.de. Acesso em janeiro 2017.

Cálculo do BAF:

$140 \mathrm{~m}^{2}$ asfalto

$x 0.0=00 \mathrm{~m}^{2}$

$59 m^{2}$ cascalho com cobertura de grama

$x 0.5=30 \mathrm{~m}^{2}$

$1 \mathrm{~m}^{2}$ de solo permeável

$\mathrm{x} 1 \cdot 0=1 \mathrm{~m}^{2}$

$$
B A F \frac{31}{479}=0,06
$$

\section{BAF objetivo $=0.3$}

\section{Variação 1:}

Alcançar o BAF objetivo exigirá medidas que equivalem a um BAF de 0,24. Ao reduzir a área de cobertura pelo asfalto e mudar o tipo de superfície, e expandindo significativamente a área coberta por vegetação, o BAF de 0,3 pode ser realizado sobre esta parte do terreno. 


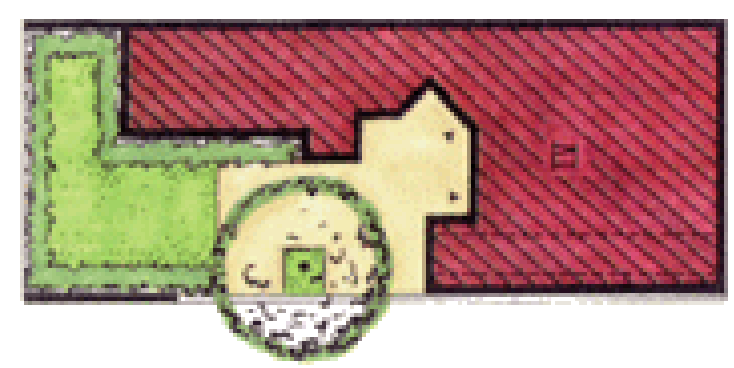

Figura 73 - Terreno modelo utilizado para cálculo do BAF, variação 1. Fonte: www.stadtentwicklung.berlin.de. Acesso em janeiro 2017.

\section{Cálculo: BAF Variação 1}

$115 \mathrm{~m}^{2}$ área coberta por

$$
x 1.0=115.0 \mathrm{~m}^{2}
$$

vegetação

$85 \mathrm{~m}^{2}$ pavimento em mosaico

$$
x 0.3=25.5 \mathrm{~m}^{2}
$$

$$
B A F \frac{140,5}{479}=0,03
$$

\begin{tabular}{|c|c|c|c|c|c|}
\hline \multicolumn{2}{|c|}{$\begin{array}{l}\text { Terreno } \\
\text { Exemplo de cálculo }\end{array}$} & Área Total & $\begin{array}{l}\text { Área } \\
\text { Construída }\end{array}$ & $\begin{array}{l}\text { Área não } \\
\text { Construída }\end{array}$ & $\begin{array}{l}\text { BAF } \\
\text { existente } \\
(0,06) \\
\text { BAF } \\
\text { pretendido } \\
\mathbf{0 . 3}\end{array}$ \\
\hline \multirow{2}{*}{\multicolumn{2}{|c|}{$\begin{array}{l}\text { Fator de ponderação por } \mathrm{m}^{2} \text { de tipo } \\
\text { de superfície }\end{array}$}} & \multicolumn{4}{|c|}{$\begin{array}{l}\text { Parte relativa de cada tipo de superfície na } \\
\text { composição total }\left(\mathrm{m}^{2}\right)\end{array}$} \\
\hline & & $\begin{array}{l}\text { Quantidade } \\
\text { existente }\end{array}$ & $\begin{array}{l}\text { EEA }^{*} \\
\text { existente }\end{array}$ & Projeto & $\begin{array}{l}E E A^{*} \\
\text { pretendido }\end{array}$ \\
\hline 1 & $\begin{array}{l}\text { Superfície selada } \\
0,00\end{array}$ & 140 & 0 & & \\
\hline 2 & $\begin{array}{l}\text { Superfície parcialmente selada } \\
0,30\end{array}$ & & & 85 & 25,5 \\
\hline 3 & Superfícies semi-porosas 0,50 & 59 & 30 & & \\
\hline
\end{tabular}

Tabela 10 - Exemplo de cálculo variação 1. 


\begin{tabular}{|c|c|c|c|c|c|}
\hline 4 & $\begin{array}{l}\text { Superfícies com vegetação } \\
\text { desconectadas do solo natural } \\
0,50\end{array}$ & & & & \\
\hline 5 & $\begin{array}{l}\text { Superfícies com vegetação } \\
\text { desconectadas do solo natural } \\
0,7\end{array}$ & & & & \\
\hline 6 & $\begin{array}{l}\text { Superfícies com vegetações } \\
\text { conectadas do solo natural } 1,0\end{array}$ & 1 & 1 & 115 & 115 \\
\hline 7 & $\begin{array}{l}\text { Infiltração de água de chuva } \\
\text { por } \mathrm{m}^{2} \text { de telhado } \\
0,2\end{array}$ & & & & \\
\hline 8 & $\begin{array}{l}\text { Parede verde com altura } \\
\text { máxima de } 10 \mathrm{~m} \\
0,50\end{array}$ & & & & \\
\hline 9 & $\begin{array}{l}\text { Telhado Verde } \\
0,70\end{array}$ & & & & \\
\hline \multicolumn{2}{|c|}{$\begin{array}{l}\text { Área de superfície ecologicamente } \\
\text { ativa }\end{array}$} & & 31 & & 140,5 \\
\hline \multicolumn{3}{|c|}{$B A F=\frac{\text { área de superfície efetivamente ecológica }}{\text { área total do terreno }}$} & \multicolumn{3}{|c|}{$\begin{array}{l}\text { EEA=porção de área de superfície } \\
\text { efetivamente ecologicamente }\end{array}$} \\
\hline \multicolumn{3}{|c|}{$B A F \frac{140,5}{479}$} & $\begin{array}{c}\text { BAF } \\
\text { existente } \\
0,06\end{array}$ & & $\begin{array}{c}\text { BAF } \\
\text { pretendido } \\
0,30\end{array}$ \\
\hline
\end{tabular}

Fonte: www.stadtentwicklung.berlin.de. Acesso em janeiro 2017.

\section{Variação 2:}

Ao se construir um bicicletário coberto parte de superfícies parcialmente fechadas deve ser aumentada. Por conseguinte, é necessária a utilização de telhado e parede verde, para se de alcançar o BAF requerido. 


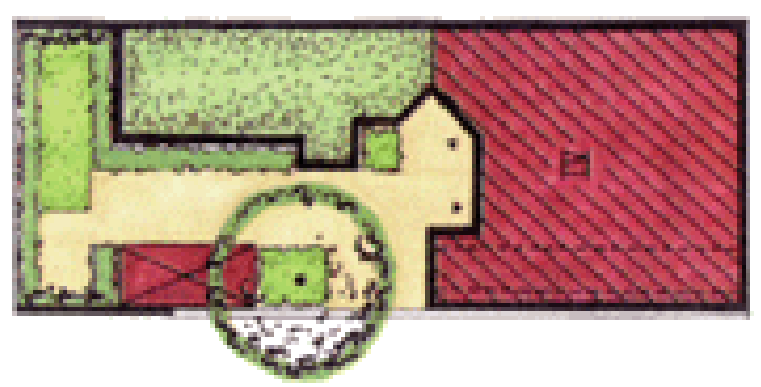

Figura 74 - Terreno modelo utilizado para cálculo do BAF, variação 2. Fonte: www.stadtentwicklung.berlin.de. Acesso em janeiro 2017.

\section{Calculo: BAF Variação 2}

$21 \mathrm{~m}^{2}$ superfície em concreto

$$
x 0.0=0.0 \mathrm{~m}^{2}
$$

$79 \mathrm{~m}^{2}$ área coberta por vegetação

$$
x 1.0=79.0 \mathrm{~m}^{2}
$$

$100 \mathrm{~m}^{2}$ pavimento em mosaico

$$
x 0.3=30.0 \mathrm{~m}^{2}
$$

$10 \mathrm{~m}^{2}$ parede verde

$$
x 0.5=5.0 \mathrm{~m}^{2}
$$

$41 \mathrm{~m}^{2}$ telhado verde

$$
x 0.7=29.0 \mathrm{~m}^{2}
$$

\begin{tabular}{|c|c|c|c|c|c|}
\hline \multicolumn{2}{|c|}{$\begin{array}{l}\text { Terreno } \\
\text { Exemplo de cálculo }\end{array}$} & Área Total & $\begin{array}{l}\text { Área } \\
\text { construída } \\
\text { 279m² }\end{array}$ & $\begin{array}{l}\text { Área não } \\
\text { construída }\end{array}$ & $\begin{array}{l}\text { BAF } \\
\text { existente } \\
(0,06) \\
\text { BAF } \\
\text { pretendido } \\
\mathbf{0 . 3}\end{array}$ \\
\hline \multirow{2}{*}{\multicolumn{2}{|c|}{$\begin{array}{l}\text { Fator de ponderação por } \mathrm{m}^{2} \text { de tipo } \\
\text { de superfície }\end{array}$}} & \multicolumn{4}{|c|}{$\begin{array}{l}\text { Parte relativa de cada tipo de superfície na } \\
\text { composição total }\left(\mathrm{m}^{2}\right)\end{array}$} \\
\hline & & $\begin{array}{l}\text { Quantidade } \\
\text { existente }\end{array}$ & $\begin{array}{l}\text { EEA }^{*} \\
\text { existente }\end{array}$ & Projeto & $\begin{array}{l}\mathrm{EEA}^{*} \\
\text { pretendido }\end{array}$ \\
\hline 1 & $\begin{array}{l}\text { Superfície selada } \\
0,00\end{array}$ & 140 & 0 & 21 & 0 \\
\hline
\end{tabular}

$$
B A F \frac{143}{479}=0,03
$$

Tabela 11 - Exemplo de cálculo variação 2. 


\begin{tabular}{|c|c|c|c|c|c|}
\hline 2 & $\begin{array}{l}\text { Superfície parcialmente selada } \\
\qquad 0,30\end{array}$ & & & 100 & 30 \\
\hline 3 & $\begin{array}{l}\text { Superfícies semi-porosas } \\
0,50\end{array}$ & 59 & 30 & & \\
\hline 4 & $\begin{array}{l}\text { Superfícies com vegetação } \\
\text { desconectadas do solo natural } \\
0,50\end{array}$ & & & & \\
\hline 5 & $\begin{array}{l}\text { Superfícies com vegetação } \\
\text { desconectadas do solo natural } \\
0,7\end{array}$ & & & & \\
\hline 6 & $\begin{array}{l}\text { Superfícies com vegetações } \\
\text { conectadas do solo natural } \\
1,0\end{array}$ & 1 & 1 & 79 & 79 \\
\hline 7 & $\begin{array}{l}\text { Infiltração de água de chuva } \\
\text { por } \mathrm{m}^{2} \text { de telhado } \\
0,2\end{array}$ & & & & \\
\hline 8 & $\begin{array}{l}\text { Parede verde com altura } \\
\text { máxima de } 10 \mathrm{~m} \\
0,50\end{array}$ & & & 10 & 5 \\
\hline 9 & $\begin{array}{l}\text { Telhado Verde } \\
0,70\end{array}$ & & & 41 & 29 \\
\hline \multicolumn{2}{|c|}{$\begin{array}{l}\text { Área de superfície ecologicamente } \\
\text { ativa }\end{array}$} & & 31 & & 143 \\
\hline \multicolumn{3}{|c|}{$B A F=\frac{\text { área de superfície ef etivamente ecológica }}{\text { área total do terreno }}$} & \multicolumn{3}{|c|}{$\begin{array}{l}\text { EEA=porção de área de superfície } \\
\text { efetivamente ecologicamente }\end{array}$} \\
\hline \multicolumn{3}{|c|}{$B A F \frac{143}{479}$} & $\begin{array}{c}\text { BAF } \\
\text { existente } \\
0,06\end{array}$ & & $\begin{array}{c}\text { BAF } \\
\text { pretendido } \\
0,30\end{array}$ \\
\hline
\end{tabular}

Fonte: www.stadtentwicklung.berlin.de. Acesso em janeiro 2017.

O BAF considera os tipos de superfície através de fotos aéreas e questionários porém não está claro se a eficácia ecológica das áreas estimadas pelo sistema BAF é consistente com as características ecológicas reais e a diversidade de organismos habitáveis. Seus estudos indicaram que a efetividade ecológica da área urbana atual quantificando o sistema BAF pode não ser apropriada. $O$ autor 
sugere que, em estudos futuros, seja realizado um ajuste na escala de operação e feita uma consideração de fatores que influenciam a biodiversidade no sistema de ponderação para designar realisticamente e com precisão a eficácia ecológica das unidades (HUANG et al., 2015).

Keeley (2011) apresenta uma crítica ao BAF, sugerindo que o instrumento não seja capaz de cumprir totalmente a promessa de ser um método urbano global, cientificamente compatível para incentivar a sustentabilidade local. A autora destaca a insuficiência de instrumentos de monitoramento dos impactos reais da implantação do BAF, ressaltando que embora o instrumento se baseie na prestação de múltiplos serviços ambientais, seus parâmetros não parecem ter sido baseados numa avaliação científica na sua concepção, assim, a autora sugere que futuras aplicações sejam baseadas em avaliações científicas de déficits ambientais locais. A autora também sugere que muitos aspectos do desenvolvimento e da implementação do instrumento poderiam ser substancialmente melhorados com uma compreensão mais detalhada dos déficits ambientais, como a identificação de áreas críticas da ilha de calor urbana, possibilitando a criação de uma classificação de desempenho ambiental específica para essas áreas. A utilização de serviços de geoprocessamento poderia melhorar o monitoramento e a avaliação dos resultados ambientais, sociais e econômicos do BAF. A autora levanta ainda a dúvida sobre por que razão este instrumento não tem uma aplicação mais ampla, mesmo dentro da Alemanha (KEELEY, 2011).

\section{Seattle Green Factor, Seattle}

Implementado em 2007, o Seattle Green Factor - SGF tem como objetivo não apenas proporcionar benefícios ambientais, mas também, melhorar a qualidade da paisagem urbana (SEATTLE, 2016). O SFG é calculado pela soma ponderada de cada elemento da paisagem. Recebem maior pontuação: as coberturas e paredes verdes e os pavimentos permeáveis, além da vegetação plantada em solo com profundidade maior que $61 \mathrm{~cm}$ (STENNING, 2008). 
Recebem bônus o plantio de espécies nativas ou tolerantes à seca, o cultivo de hortas, a utilização de água da chuva para a irrigação ou a utilização de lugares com visibilidade pública para o plantio de vegetação (MORLEY, 2008).

O SGF incide em parte da cidade de Seattle, a Figura 75 apresenta onde foram delimitadas novas zonas de desenvolvimento urbano, com pontuação variável entre 0,30 e 0,50 para as diferentes zonas urbanas ${ }^{35}$.

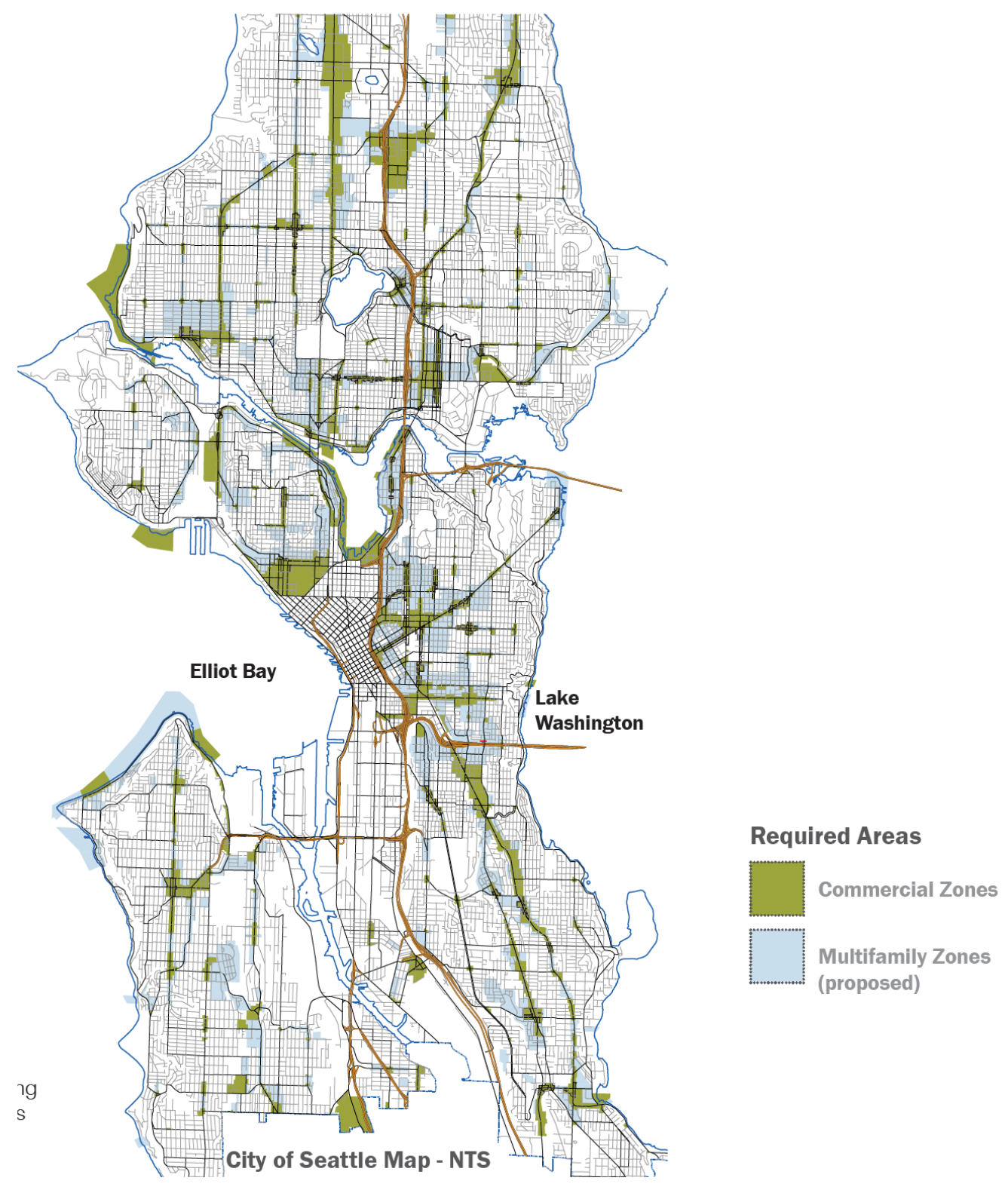

Figura 75 - Zonas de desenvolvimento urbano Seattle, Fonte: HIRST et al., 2008.

35 Disponível em: < http://www.seattle.gov/dpd/codesrules/changestocode/greenfactor/whatwhy/default.htm> Acesso em janeiro de 2017. 
Várias zonas comerciais estão isentas dos requisitos do SGF. Por exemplo, as zonas comerciais no centro da cidade de Seattle devem aderir às exigências de espaços abertos do antigo código comercial, porque foi considerado muito difícil para edifícios altos satisfazerem esses requisitos (STENNING, 2008). Áreas industriais, de infraestruturas e residências privadas constituem grandes porções da cidade que não estão sujeitas às regulamentações do SGF (MORLEY, 2008).

As melhorias de paisagem atingem os objetivos urbanísticos ajudando a adaptar novos edifícios ao seu entorno, amortecendo usos incompatíveis, fornecendo proteção e privacidade, reduzindo o brilho dos faróis e criando um ambiente urbano agradável. Eles também proporcionam benefícios ambientais, reduzindo o escoamento de águas pluviais, melhorando a qualidade do ar e da água, diminuindo o efeito de ilha de calor urbana, melhorando a eficiência energética e fornecendo habitat de vida selvagem ${ }^{36}$.

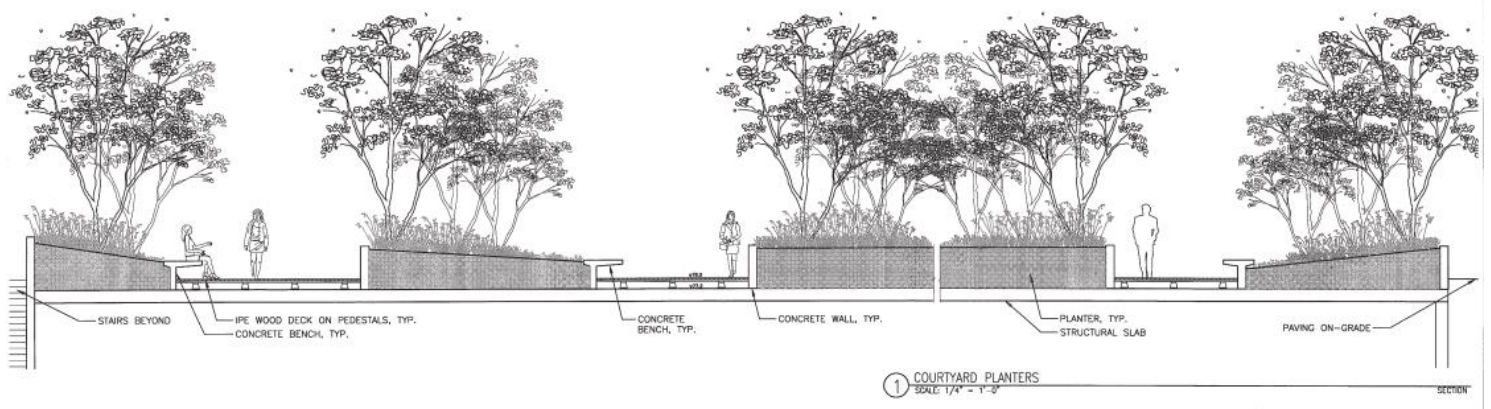

Figura 76 - Seattle DPD - Corporate Campus, Amazon Phase IV, plantas de paisagismo. Disponível em $<h t t p: / / w w w . s e a t t l e . g o v / d p d / c s / g r o u p s / p a n / @ p a n / d o c u m e n t s / w e b \_i n f o r m a t i o n a l / s 048147 . p d f>$ Acesso em janeiro de 2017.

Segundo Morley et al. (2008), são elementos de bônus:

- Plantas tolerantes à seca ou nativas: as plantas tolerantes à seca devem ser separadas das plantas que necessitam de irrigação para receber crédito. Uma lista de plantas tolerantes à seca está disponível ${ }^{37}$, caso

\footnotetext{
${ }^{36}$ Directors Rule 30-2015, Standards for Landscaping, including Green Factor, 12/22/15.

37 Disponível em: < http://www.seattle.gov/dpd/codesrules/changestocode/greenfactor/whatwhy/default.htm> Acesso em janeiro de 2017.
} 
contrário duas referências são necessárias para mostrar a tolerância à seca.

- $50 \%$ de irrigação realizada por águas pluviais: a captação de águas pluviais pode ser obtida através do uso de cisternas ou outros meios de armazenamento. Qualquer área ajardinada que tenha mais de 50\% de sua irrigação fornecida por água proveniente de sistema de coleta pode receber este bônus.

- Visibilidade Pública: este bônus está disponível para a maioria dos espaços visíveis a partir de áreas públicas.

- Cultivo de Alimentos: projetos multifamiliares normalmente apresentam grandes possibilidades para inserção de áreas para de cultivo de alimentos.

\section{Green Space Factor \& Green Points System, Malmö, Suécia}

O Green Space Factor \& Green Points System é um conjunto de indicadores que começou a ser desenvolvido no contexto de uma exposição internacional de habitação que ocorreu em Malmö em 2001, que era composta por uma área de exposições temporária e um novo bairro residencial com 500 habitações, em sua maioria apartamentos. Essa área ficou conhecida como Bo01, e se localiza no Western Harbor (Västra Hamnen) de Malmö.

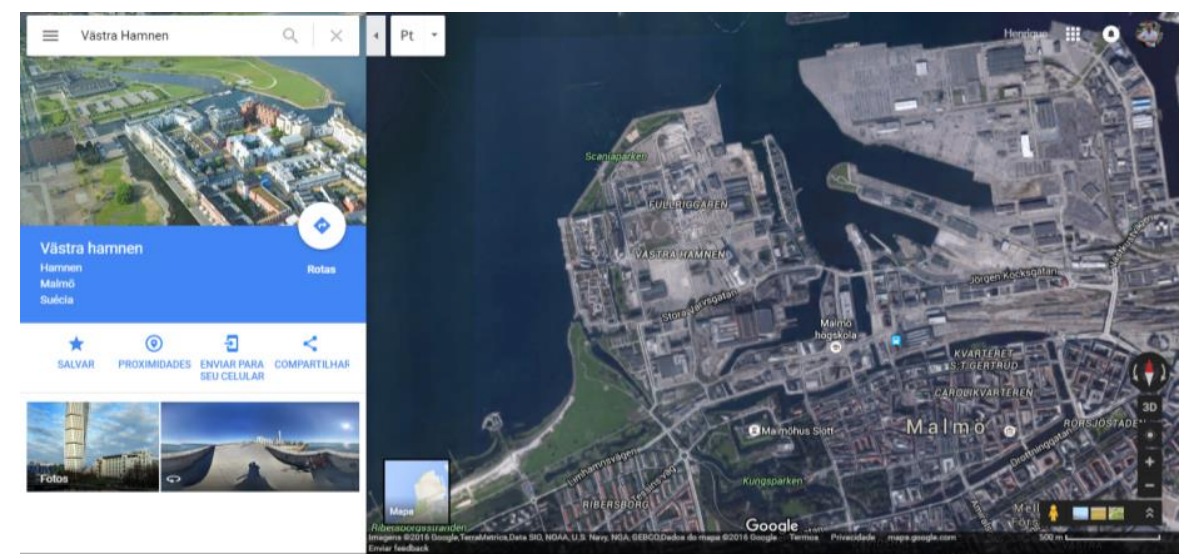

Figura 77 - Vista aérea de Western Harbor, Malmö. Fonte: Google Maps, acesso em janeiro 2017. 
A área é um antigo aterro sobre o mar, e o projeto desenvolvido buscou diferenciar-se dos projetos tradicionais, optando por ruas curvas que aumentam a curiosidade dos visitantes, além de localizar os prédios mais altos na beira mar, protegendo os prédios interiores dos ventos frios. Além disso, medidas foram implementadas para melhorar o desempenho ambiental do novo bairro relacionadas à produção local de energia renovável, gestão de resíduos sólidos e mobilidade.

Malmö foi construída em terras anteriormente dedicadas à agricultura, apresentando topografia predominantemente plana, não possuindo colinas, florestas ou outros obstáculos naturais à ocupação, com poucas áreas verdes de lazer. Apresenta poucos canais naturais para a drenagem das águas pluviais, que são em geral, direcionadas diretamente ao mar. Alguns lugares, no entanto, estão sujeitos a enchentes e processos erosivos.

A oportunidade de melhorar a gestão das águas pluviais em um bairro residencial denso foi aproveitada no desenvolvimento do Bo01. A gestão em áreas públicas é feita através de sistemas abertos como canais de concreto ou pequenas bacias com ou sem vegetação. Além disso, cada pátio dos edifícios possui seu próprio sistema de bacias para águas pluviais.

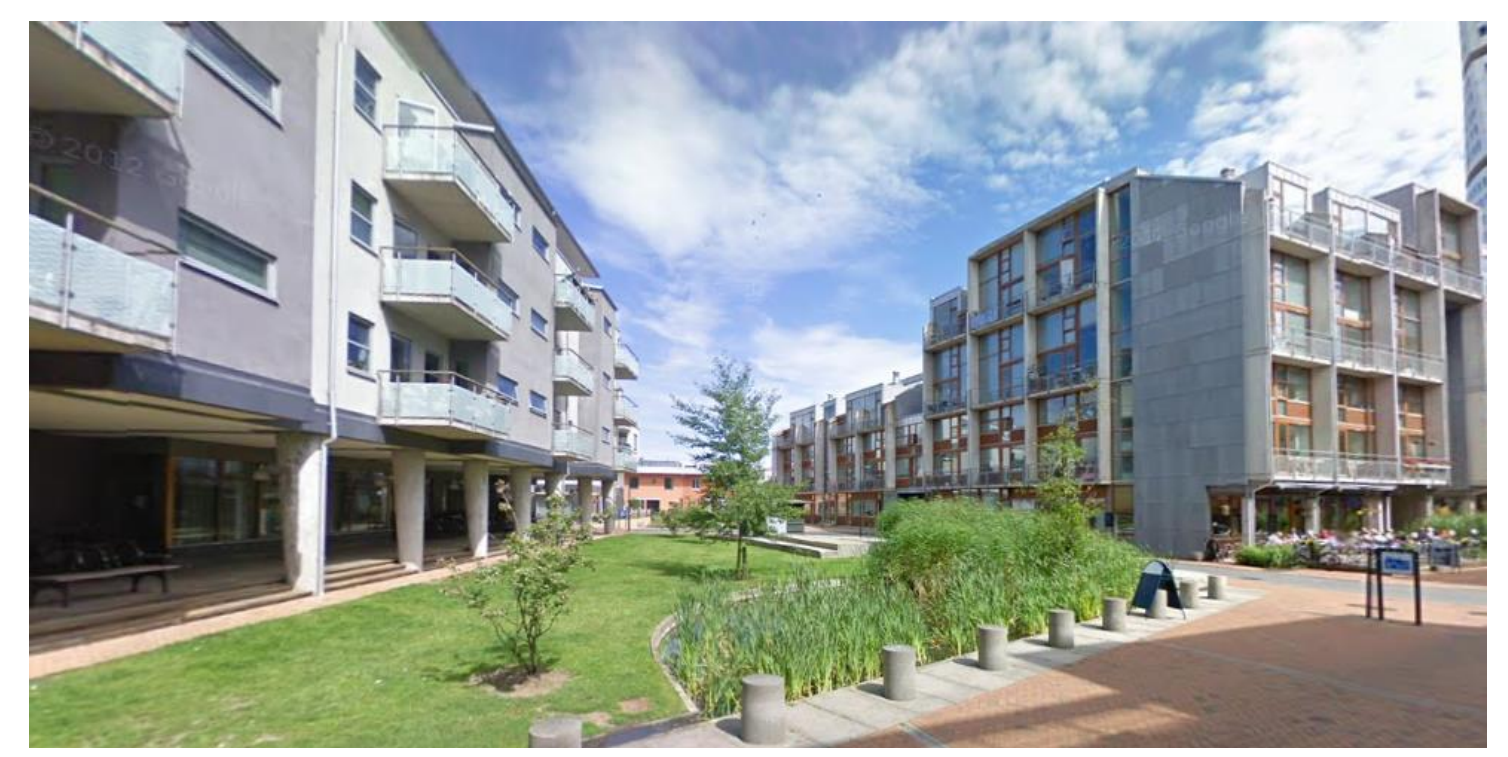

Figura 78 - Sistema para águas pluviais - Malmö. Fonte: Google Maps, acesso em janeiro 2017. 
Com o objetivo de aumentar a cobertura verde nos lotes e aumentar as superfícies permeáveis, foi desenvolvido o Green Space Factor - GSF, que se aplica à escala do lote, como um todo, incluindo os pátios internos privados, embora exista a possibilidade de cruzamento pelos transeuntes.

Embora a fórmula seja a mesma, a definição dos fatores mínimos e sua pontuação alteraram-se ao longo da evolução da metodologia em diferentes empreendimentos. O cálculo de GSF se dá através da seguinte equação:

$$
\begin{aligned}
& G S F \\
& =\frac{(\text { Área } A \times \text { Fator } A)+(\text { Área } B \times \text { Fator } B)+(\text { Área } C \times \text { Fator } C)+(\ldots)}{\text { Área total do pátio }}
\end{aligned}
$$

Na primeira fase de aplicação do GSF no Bo01, os empreendimentos deveriam alcançar um fator mínimo de 0,5.

Os fatores a serem aplicados são os que aparecem na Tabela 12, conforme a versão mais recente do GSF.

Tabela 12 - Tipo de Superfície.

\begin{tabular}{|l|c|}
\hline \multicolumn{2}{|c|}{ Green Space Factor } \\
\hline \multicolumn{1}{|c|}{ Tipo de Superfície } & Fator \\
\hline Vegetação no solo & 1 \\
\hline Vegetação sobre treliça ou fachada & 0,7 \\
\hline Telhados verdes & 0,6 \\
\hline Vegetação sobre laje, profundidade entre \\
0,20 e 0,80m
\end{tabular}




\begin{tabular}{|l|c|}
\hline $\begin{array}{l}\text { Vegetação sobre laje, profundidade } \\
\text { superior a 0,80m }\end{array}$ & 0,9 \\
\hline Superfícies hídricas & 1 \\
\hline $\begin{array}{l}\text { Superfícies de coleta de água e retenção } \\
\text { de águas pluviais }\end{array}$ & 0,2 \\
\hline $\begin{array}{l}\text { Drenagem de superfícies } \\
\text { impermeabilizadas em áreas vegetadas }\end{array}$ & 0,2 \\
\hline $\begin{array}{l}\text { Áreas impermeabilizadas } \\
\text { Árvores com circunferência do tronco } \\
\text { superior a 30 cm }\end{array}$ & 0 \\
\hline $\begin{array}{l}\text { Árveas pavimentadas com a presença de } \\
\text { junções }\end{array}$ & 10 \\
\hline entre $16-20$ cm & 0,2 \\
\hline
\end{tabular}

Fonte: http://www.ginw.co.uk/resources/gi_toolkit.xls> Acesso em janeiro de 2017.

Adicionalmente ao GSF, foi implementado o Green Points System - GPS, que em uma primeira fase consistia em selecionar 10 medidas de uma lista de 35 relacionadas a diferentes questões ambientais. 
A próxima fase de aplicação foi na implantação do GSF, na qual houve uma alteração do fator mínimo que estava relacionado à ocupação do lote. Se o edifício ocupasse $60 \%$ do site, o GSF deveria ser 0,4 .

Após esta fase, o sistema passou por mais algumas revisões, e o GSF mínimo passou a ser 0,6, e é utilizado no Western Harbor (Västra Hamnen) e alguns outros empreendimentos em Malmö.

As cidades de Malmö e Lund implementaram em 2009 um programa com três níveis ( $A, B$ e $C$ ), sendo que o GSF mínimo fica como $A=0,5 ; B=0,45$ e $C=0,4$; embora similar, não é idêntico ao aplicado no Western Harbor. Ele está sendo revisado e deve incorporar questões de biodiversidade e eliminará desta forma, o GPS, por já tê-lo incorporado.

A partir dos trabalhos do GSF e GPS, um conjunto de ferramentas foi desenvolvido em uma plataforma aberta que pode ser adaptada e adotada também por outras cidades ${ }^{38}$.

\section{Green Plot Ratio, Singapura}

Singapura é uma cidade-estado localizada em uma ilha próxima à Malásia do Sul, apresenta-se como um centro financeiro global com clima tropical.

O objetivo do Plano Diretor (2008) da autoridade de planejamento nacional de Singapura é criar uma cidade tropical de excelência ${ }^{39}$. Atualmente, Singapura está dividida em 55 áreas de planejamento, que podem ser observadas na Figura 79. Para cada uma dessas áreas, foram desenvolvidas propostas específicas de planejamento local.

${ }^{38}$ Disponível em: <http://www.ginw.co.uk/resources/gi toolkit.xls> Acesso em janeiro de 2017.

39 Disponível em: https://www.ura.gov.sg/uol/master-plan.aspx> Acesso em janeiro de 2017. 
Cada um dos 55 Relatórios de Áreas de Planejamento elabora a proposta de planejamento referente ao uso do solo, intensidade e altura do edifício. Também identifica áreas onde há controles especiais e diferenciados.

A intensidade da ocupação não residencial é expressa em termos da razão de parcela bruta do Green Plot Ratio - GPR.

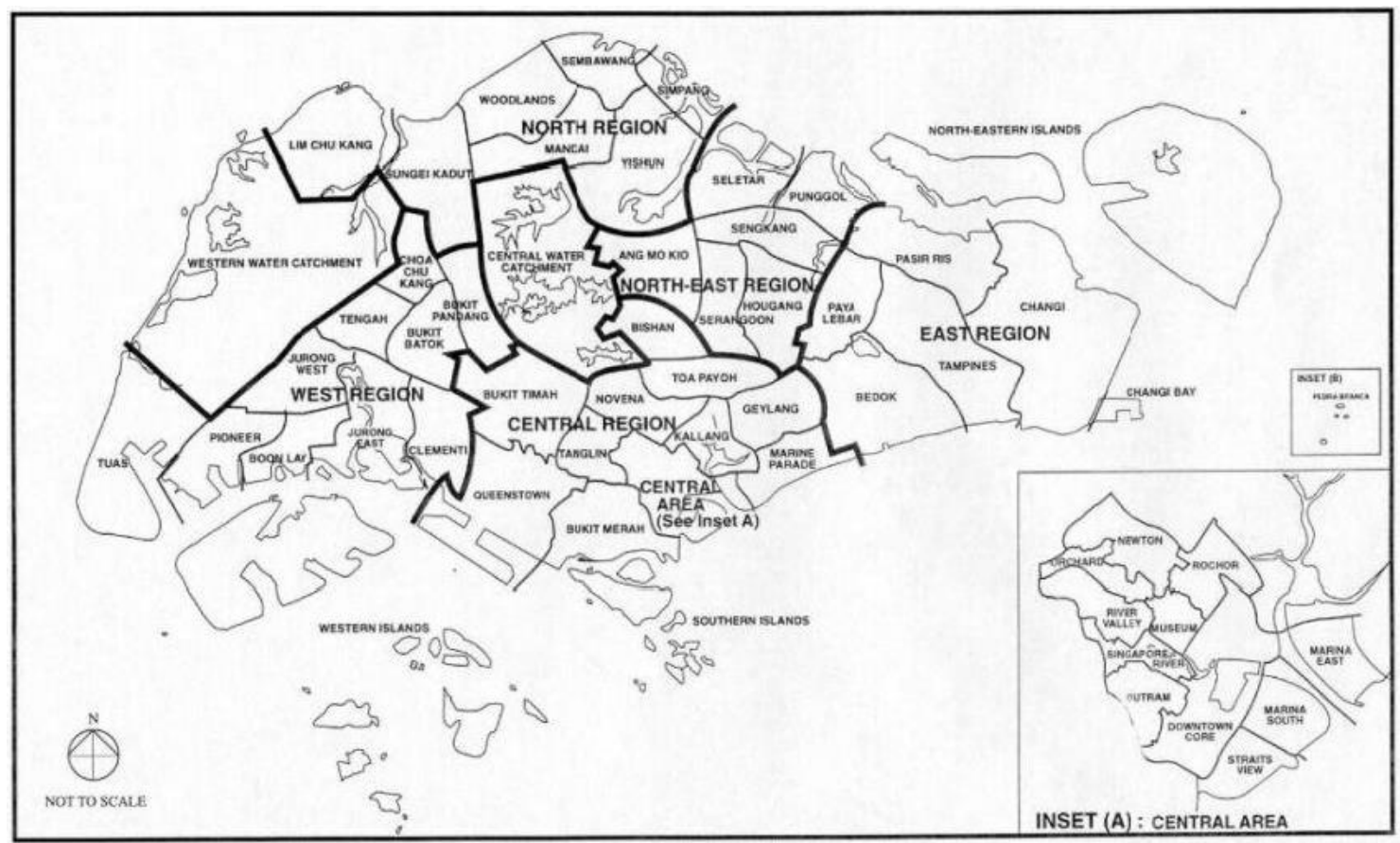

Figura 79 - Demarcações das áreas de Planejamento de Singapura. Disponível em $<$ https://www.ura.gov.sg/uol/master-plan.aspX> Acesso em janeiro de 2017

O coeficiente de aproveitamento máximo permitido é determinado pelo controle do GPR especificado no Plano Diretor de 2008. O potencial máximo estabelecido pelo GPR pode não ser alcançado devido às limitações impostas pela configuração do local, terreno, layout, reveses de construção, altura, cobertura do local além dos requisitos técnicos que afetem o sítio.

Para os locais aos quais não são atribuídos um controle do parcelamento no Plano Diretor 2008, o GPR será sujeito à avaliação do departamento de planejamento.

As áreas verdes pós-implantação dos empreendimentos imobiliários devem ser ao menos equivalentes à área do terreno. No entanto, em áreas onde há um 
controle técnico de altura, pode haver restrições de projeto para a provisão de $100 \%$ de substituição de paisagem. Para os empreendimentos fora da Área Central que sejam submetidos a uma restrição técnica de altura de $80 \mathrm{~m}$ acima e abaixo do nível médio do mar, as áreas de substituição de paisagem necessárias serão reduzidas para $70 \%$ da área. Pelo menos $40 \%$ da área do terreno, ou das áreas de reposição de paisagem requeridas, o que for maior, deve ser destinado para plantio permanente, projetado com profundidade suficiente para acomodar os tipos de plantas propostas. O Plano Diretor sugere ainda a utilização de combinação de árvores, palmeiras, arbustos e cobertura do solo para tornar o paisagismo mais atraente.

O GPR foi inicialmente introduzido como conceito em 2002, seu princípio é prover um método de medição das relações entre as vegetações de um local.

O Green Plot Ratio é baseado essencialmente na média do LAI ou IAF para uma área construída, sendo que seus benefícios primários são a correspondência do IAF de um ecossistema natural que pode ser facilmente calculado, medido e regulamentado. Propriedades residenciais devem ser capazes de incorporar maior quantidade de vegetação enquanto propriedades comerciais e industriais podem incorporar menores quantidades. O National Parks Board Singapore NParks define o GPR como a área média ponderada da área foliar de um local; para o cálculo do GPR, o IAF de cada espécie deve ser multiplicado pela área do dossel ou área de plantio, o que determina a área foliar total da planta, e o cálculo para a soma das espécies no terreno deve ser dividida pela área do terreno (ONG, 2003).

O cálculo pode ser expresso por:

$$
\begin{aligned}
& G P R=\frac{\text { área total foliar }}{\text { área do terreno }}
\end{aligned}
$$

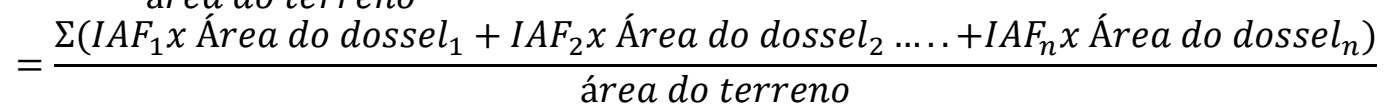

A área do dossel é o rebatimento da área de projeção horizontal da planta no solo. É estimada como uma área bidimensional no terreno onde planta está inserida. 
A importância do IAF está no fato dele ser um denominador comum em muitos dos efeitos ecológicos das plantas. A copa das plantas tem um gradiente vertical de luz solar relacionado com a quantidade de folhas. A luz solar que atinge uma folha individualmente é absorvida, refletida ou transmitida pela folha. Como a copa torna-se mais densa com as folhas, mais radiação solar é absorvida ou refletida e menos é transmitida no interior do dossel (BONAN, 2008).

Entretanto, o IAF e a área do dossel são variáveis não tão simples de se obter, especialmente para plantas ornamentais tropicais. Os valores do IAF e da área do dossel são geralmente limitados ou inexistentes, não apresentando valores fixos, mas flutuantes de acordo com as condições ambientais. Essas dificuldades práticas tornam o cálculo do GPR uma tarefa desafiadora e exigem a coleta inicial de dados empíricos.

O Centro para Vegetação Urbana e Ecologia de Singapura - CUGE tem um projeto para desenvolvimento de um banco de dados de valores de IAF e áreas de dossel das plantas mais comumente utilizadas em Singapura; esse projeto é desenvolvido juntamente com o NParks e JTC Corporation.

\section{Quota Ambiental}

Em março de 2016, foi aprovada a Lei Municipal no 16.402, de 22 de março de 2016, que disciplina o parcelamento, o uso e a ocupação do solo no Município de São Paulo, de acordo com a Lei no 16.050, de 31 de julho de 2014 - Plano Diretor Estratégico (PDE) ${ }^{40}$.

“Art. 74. A quota ambiental (QA) corresponde a um conjunto de regras de ocupação dos lotes objetivando qualificá-los ambientalmente, tendo como referência uma medida da eficácia ambiental para cada lote, expressa por um índice

\footnotetext{
${ }^{40}$ Disponível em < http://gestaourbana.prefeitura.sp.gov.br/wp-content/uploads/2016/03/PL-272-15-comraz\%C3\%B5es-de-veto1.pdf> Acesso em dezembro de 2016.
} 


\section{que agrega os indicadores Cobertura Vegetal (V) e Drenagem (D).”}

A Quota Ambiental - QA tem por finalidade promover a qualificação ambiental, em especial a melhoria da retenção e infiltração da água nos lotes, a melhoria do microclima e a ampliação da vegetação (Art. 4º, inciso VII).

Pode-se perceber no texto da QA a relativização do instrumento de acordo com cada região do município de São Paulo, considerando-se a heterogeneidade dos bairros que compõem a sua área urbana. A cidade foi dividida em 13 zonas, criadas a partir das Macroáreas do Plano Diretor aprovado em 2014. Essas zonas são diferenciadas segundo seus aspectos geomorfológicos e sua cobertura vegetal.

A QA apresenta-se como exigência para lotes com processos de licenciamento de edificações novas ou de reformas com alteração de área construída superior a $20 \%$ (Art. 76), sendo que estão isentos da QA:

- Lotes com área total menor ou igual a $500 \mathrm{~m}^{2}$, ressalvados os casos de lote originário de desmembramento ou desdobro, realizado após a vigência desta lei, em que o lote original tenha área superior à mínima exigida (Art. 76, $\S 2^{\circ}$ );

- Imóveis inseridos no perímetro da Operação Urbana Centro, cuja taxa de ocupação existente e regular seja superior a 0,7 (Art. 76, § $3^{\circ}$ );

- Toda a Macroárea de Contenção Urbana e Uso Sustentável e na Macroárea de Preservação dos Ecossistemas Naturais, agrupadas no Perímetro de Qualificação Ambiental - PA13 (Art. 76, § 4ำ;

- Estacionamentos localizados no subsolo, quando da emissão de novas licenças de funcionamento (Art. 76, $\S 7^{\circ}$ ).

A QA deve ser calculada pela seguinte equação (Art. 75.):

$$
Q A=V^{\alpha} x D^{\beta}
$$


Onde:

V: indicador Cobertura Vegetal, calculado a partir do Quadro 3B desta lei;

D: indicador Drenagem, calculado a partir do Quadro 3B desta lei;

$\alpha$ e $\beta$ : fatores de ponderação, definidos no Quadro 3A desta lei. 
Quadro 3A :: Quota Ambiental: Pontuaçăo minima, taxa de permeabilidade mínima e fatores por perimetros de qualificaçăo ambiental

SAEP PAULO

\begin{tabular}{|c|c|c|c|c|c|c|c|c|c|c|c|}
\hline \multirow{2}{*}{$\begin{array}{l}\text { MACROZO } \\
\text { NA }\end{array}$} & \multirow{2}{*}{ MACROÁREA } & \multirow{2}{*}{$\begin{array}{l}\text { Perimetro de } \\
\text { Qualificação } \\
\text { Ambiental }\end{array}$} & \multicolumn{2}{|c|}{ TAXA DE PERMEABILIDADE (a) } & \multicolumn{5}{|c|}{ PONTUAÇÃO MINIIMA DE QUOTA AMBIENTAL (QA MIN) } & \multicolumn{2}{|c|}{ FATORES } \\
\hline & & & $\begin{array}{l}\text { Lote }<= \\
500 \mathrm{~m}^{2}\end{array}$ & $\begin{array}{l}\text { Lote > } \\
500 \mathrm{~m}^{2}\end{array}$ & $\begin{array}{l}\text { Lote }>500 \mathrm{e}<= \\
\quad 1000 \mathrm{~m}^{2}\end{array}$ & $\begin{array}{c}\text { Lote }>1000 \text { e }<= \\
\quad 2500 \mathrm{~m}^{2}\end{array}$ & $\begin{array}{l}\text { Lote }>2500 \mathrm{e}<= \\
\quad 5000 \mathrm{~m}^{2}\end{array}$ & $\begin{array}{c}\text { Lote }>5000 \mathrm{e}<= \\
10000 \mathrm{~m}^{2}\end{array}$ & $\begin{array}{l}\text { Lote> } \\
10000 \mathrm{~m}^{2}\end{array}$ & $\begin{array}{l}\text { Cobertura } \\
\text { Vegetal (alfa) }\end{array}$ & Drenagem (beta) \\
\hline \multirow{17}{*}{ 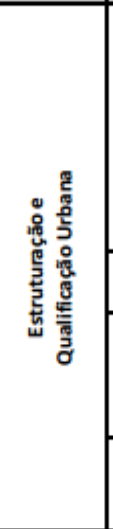 } & \multirow{8}{*}{ Estruturação Metropolitana } & MEM-1 & 0,15 & 0,25 & 0,40 & 0,52 & 0,64 & 0,70 & 0,86 & 0,50 & 0,50 \\
\hline & & MEM-2 & 0,15 & 0,25 & 0,45 & 0,60 & 0,70 & 0,80 & 1,00 & 0,50 & 0,50 \\
\hline & & MEM-3 & 0,15 & 0,25 & 0,37 & 0,48 & 0,60 & 0,65 & 0,78 & 0,60 & 0,40 \\
\hline & & MEM-4 & 0,15 & 0,25 & 0,34 & 0,44 & 0,55 & 0,60 & 0,71 & 0,50 & 0,50 \\
\hline & & MEM-5 & 0,15 & 0,25 & 0,40 & 0,52 & 0,64 & 0,70 & 0,86 & 0,50 & 0,50 \\
\hline & & MEM-6 & 0,15 & 0,25 & 0,37 & 0,48 & 0,60 & 0,65 & 0,78 & 0,60 & 0,40 \\
\hline & & MEM-7 & 0,15 & 0,25 & 0,31 & 0,41 & 0,51 & 0,55 & 0,64 & 0,30 & 0,70 \\
\hline & & MEM-8 & 0,15 & 0,25 & 0,42 & 0,55 & 0,69 & 0,75 & 0,93 & 0,60 & 0,40 \\
\hline & \multirow{2}{*}{ Urbanização Consolidada } & MUC-1 & 0,15 & 0,20 & 0,29 & 0,37 & 0,46 & 0,50 & 0,57 & 0,30 & 0,70 \\
\hline & & MUC-2 & 0,10 & 0,15 & 0,34 & 0,44 & 0,55 & 0,60 & 0,71 & 0,60 & 0,40 \\
\hline & \multirow{4}{*}{ Qualificação da Urbanizaçăo } & MQU-1 & 0,10 & 0,20 & 0,34 & 0,44 & 0,55 & 0,60 & 0,71 & 0,50 & 0,50 \\
\hline & & MQU-2 & 0,10 & 0,20 & 0,29 & 0,37 & 0,46 & 0,50 & 0,57 & 0,50 & 0,50 \\
\hline & & $\mathrm{MQU}-3$ & 0,10 & 0,20 & 0,31 & 0,41 & 0,51 & 0,55 & 0,64 & 0,60 & 0,40 \\
\hline & & MQU-4 & 0,10 & 0,20 & 0,31 & 0,41 & 0,51 & 0,55 & 0,64 & 0,60 & 0,40 \\
\hline & \multirow{3}{*}{$\begin{array}{l}\text { Redução da Vulnerabilidade } \\
\text { Urbana }\end{array}$} & MRV-1 & 0,10 & 0,15 & 0,31 & 0,41 & 0,51 & 0,55 & 0,64 & 0,50 & 0,50 \\
\hline & & MRV-2 & 0,10 & 0,15 & 0,20 & 0,26 & 0,33 & 0,35 & 0,35 & 0,50 & 0,50 \\
\hline & & MRV-3 & 0,10 & 0,15 & 0,37 & 0,48 & 0,60 & 0,65 & 0,78 & 0,50 & 0,50 \\
\hline \multirow{9}{*}{ 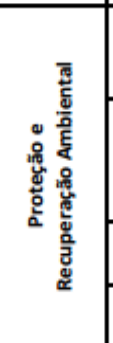 } & \multirow{3}{*}{$\begin{array}{l}\text { Reduçăo da Vulnerabilidade e } \\
\text { Recuperaçăo Ambiental }\end{array}$} & MRVRA-1 & 0,20 & 0,25 & 0,23 & 0,30 & 0,37 & 0,40 & 0,42 & 0,70 & 0,30 \\
\hline & & MRVRA-2 & 0,20 & 0,25 & 0,31 & 0,41 & 0,51 & 0,55 & 0,64 & 0,50 & 0,50 \\
\hline & & MRVRA-3 & 0,20 & 0,30 & 0,23 & 0,30 & 0,37 & 0,40 & 0,42 & 0,70 & 0,30 \\
\hline & \multirow{4}{*}{$\begin{array}{l}\text { Controle e Qualificação Urbana e } \\
\text { Ambiental }\end{array}$} & MCQA-1 & 0,20 & 0,30 & 0,20 & 0,26 & 0,33 & 0,35 & 0,35 & 0,50 & 0,50 \\
\hline & & MCQA-2 & 0,20 & 0,30 & 0,26 & 0,34 & 0,42 & 0,45 & 0,49 & 0,50 & 0,50 \\
\hline & & MCQA-3 & 0,25 & 0,30 & 0,26 & 0,34 & 0,42 & 0,45 & 0,49 & 0,50 & 0,50 \\
\hline & & MCQA-4 & 0,25 & 0,30 & 0,20 & 0,26 & 0,33 & 0,35 & 0,35 & 0,50 & 0,50 \\
\hline & $\begin{array}{l}\text { Contenção Urbana e } \\
\text { Uso Sustentável }\end{array}$ & NA & NA & NA & NA & NA & $\mathrm{NA}$ & $\mathrm{NA}$ & NA & NA & NA \\
\hline & $\begin{array}{l}\text { Preservaçăo dos Ecossistemas } \\
\text { Naturais }\end{array}$ & NA & NA & NA & NA & NA & NA & NA & NA & NA & NA \\
\hline
\end{tabular}

Notas:

NA = Não se Aplica

(a) Nos lotes inseridos em ZEPAM, ZPDS e ZER deverão ser aplicadas as seguintes taxas de permeabilidade minima: 0,90, 0,70 e 0,30, respectivamente.

Figura 80: Quadro 3A Quota Ambiental de São Paulo. Disponível em:< http://gestaourbana.prefeitura.sp.gov.br/wp-content/uploads/2014/12/2014-12-23QUADRO-3A-minuta-PL-LPOUS-vfinal.pdf> acesso em dezembro 2016. 
ANEXO AO PROJETO DE LEI DE REVSÃO PARTICIPATIVA DA LEI DE PARCELAMENTO, USO OCUPAÇÃO DOSOLO

Quadro 3B - Composição da pontuaçăo da Quota Ambiental | Folha 1 de 2

\begin{tabular}{|l|c|}
\hline ITEM L. CARACTERISTICAS DO LOTE & inserir área \\
\hline Área total do lote - A (m) & ver mapa 3 \\
\hline Perimetro de Qualificação Ambiental & ver quadro $3 \mathrm{~A}$ \\
\hline Taxa de Permeabilidade - TP & ver quadro $3 \mathrm{~A}$ \\
\hline Fator alfa $\alpha$ & ver quadro $3 \mathrm{~A}$ \\
\hline Fator beta $\beta$ & ver quadro $3 \mathrm{~A}$ \\
\hline QA minimo obrigatório & \\
\hline
\end{tabular}

\begin{tabular}{|c|c|c|c|c|c|}
\hline SOLUÇŌES CONSTRUTIVAS E PAISAGÍSTICAS & PROJETO (1) & UNID. & $\begin{array}{l}\text { FATOR } \\
\text { FV (2) }\end{array}$ & $\begin{array}{l}\text { TCA } \\
(5)\end{array}$ & $\begin{array}{l}\text { PONTUAÇĀA ATINGIDA } \\
\text { (3) } \\
\end{array}$ \\
\hline \multicolumn{6}{|l|}{ A. Áreas ajardinadas } \\
\hline A1. Área ajardinada sobre solo natural & medida do projeto & $\left(\mathrm{m}^{2}\right)$ & 0,25 & $\mathrm{n} / \mathrm{a}$ & cálculo conforme (I) \\
\hline $\begin{array}{l}\text { A2. Área ajardinada sobre laje com espessura de solo maior } \\
\text { que } 40 \mathrm{~cm}\end{array}$ & medida do projeto & $\left(m^{2}\right)$ & 0,20 & $\mathrm{n} / \mathrm{a}$ & cálculo conforme (I) \\
\hline $\begin{array}{l}\text { A3. Pavimento semi-permeável com vegetaçäo sobre solo } \\
\text { natural }\end{array}$ & medida do projeto & $\left(m^{2}\right)$ & 0,10 & $\mathrm{n} / \mathrm{a}$ & cálculo conforme (I) \\
\hline \multicolumn{6}{|l|}{ B. Vegetação } \\
\hline B1. Individuo arbóreo a ser plantado de porte pequeno (4) & medida do projeto & (unidade) & 15 & TCA & cálculo conforme (1.I) \\
\hline B2. Individuo arbóreo a ser plantado de porte médio (4) & medida do projeto & (unidade) & 35 & TCA & cálculo conforme (1.1) \\
\hline B3. Individuo arbóreo a ser plantado de porte grande (4) & medida do projeto & (unidade) & 80 & TCA & cálculo conforme (I.I) \\
\hline B4. Palmeira a ser plantada (4) & medida do projeto & (unidade) & 20 & TCA & cálculo conforme (I.I) \\
\hline B5. Individuo arbóreo existente com DAP entre 20 e $30 \mathrm{~cm}$ (7) & medida do projeto & (unidade) & 80 & $\mathrm{n} / \mathrm{a}$ & cálculo conforme (I) \\
\hline B6. Individuo arbóreo existente com DAP entre 30 e $40 \mathrm{~cm}$ (7) & medida do projeto & (unidade) & 180 & $\mathrm{n} / \mathrm{a}$ & cálculo conforme (I) \\
\hline B7. Individuo arbóreo existente com DAP maior que $40 \mathrm{~cm}$ (7) & medida do projeto & (unidade) & 400 & $\mathrm{n} / \mathrm{a}$ & cálculo conforme (1) \\
\hline B8. Palmeira existente (7) & medida do projeto & (unidade) & 90 & $\mathrm{n} / \mathrm{a}$ & cálculo conforme (I) \\
\hline B9. Maciço arbóreo existente (7) & medida do projeto & $\left(\mathrm{m}^{2}\right)$ & 17 & $\mathrm{n} / \mathrm{a}$ & cálculo conforme (I) \\
\hline \multicolumn{6}{|l|}{ C. Cobertura verde } \\
\hline C1. Cob. Verde com espessura de substrato superior a $40 \mathrm{~cm}$ & medida do projeto & $\left(\mathrm{m}^{2}\right)$ & 0,20 & $\mathrm{n} / \mathrm{a}$ & cálculo conforme (I) \\
\hline $\begin{array}{l}\text { C2. Cob. Verde com espessura de substrato inferior ou igual a } \\
40 \mathrm{~cm}\end{array}$ & medida do projeto & $\left(m^{2}\right)$ & 0,15 & $\mathrm{n} / \mathrm{a}$ & cálculo conforme (I) \\
\hline \multicolumn{6}{|l|}{ D. Fachada / muro verde } \\
\hline D1. Porção de fachada / muro verde & medida do projeto & $\left(m^{2}\right)$ & 0,10 & $\mathrm{n} / \mathrm{a}$ & cálculo conforme (1) \\
\hline D2. Jardim Vertical & medida do projeto & $\left(\mathrm{m}^{2}\right)$ & 0,15 & $\mathrm{n} / \mathrm{a}$ & cálculo conforme (I) \\
\hline \multicolumn{5}{|l|}{ V PARCIAL } & cálculo conforme (II) \\
\hline \multicolumn{5}{|l|}{ V FINAL } & cálculo conforme (III) \\
\hline
\end{tabular}

Figura 81: Quadro 3B Quota Ambiental. Disponível em: $<h t t p: / / g e s t a o u r b a n a . p r e f e i t u r a . s p . g o v . b r / w p-$ content/uploads/2015/12/QUADRO_3B_18_12_15.pdf> acesso em dezembro 2016.

\begin{tabular}{|c|c|c|c|c|}
\hline \multicolumn{5}{|l|}{ ITEM III. DRENAGEM } \\
\hline SOLUÇŌES CONSTRUTIVAS E PAISAGÍSTICAS & PROJETO (1) & UNID. & FATOR FD (8) & $\begin{array}{l}\text { PONTUAÇĀO ATINGIDA } \\
\text { (9) }\end{array}$ \\
\hline A1*. Área ajardinada sobre solo & medida do projeto & $\left(\mathrm{m}^{2}\right)$ & 0,22 & cálculo conforme (IV) \\
\hline $\begin{array}{l}\text { A2*. Área ajardinada sobre laje com espessura de solo maior } \\
\text { que } 40 \mathrm{~cm}\end{array}$ & medida do projeto & $\left(m^{2}\right)$ & 0,26 & cálculo conforme (IV) \\
\hline $\begin{array}{l}\text { A3*. Pavimento semi-permeável com vegetaçāo sobre solo } \\
\text { natural }\end{array}$ & medida do projeto & $\left(m^{2}\right)$ & 0,60 & cálculo conforme (IV) \\
\hline $\mathrm{C} 1^{*}$. Cob. Verde com espessura de substrato superior a $40 \mathrm{~cm}$ & medida do projeto & $\left(\mathrm{m}^{2}\right)$ & 0,26 & cálculo conforme (IV) \\
\hline $\begin{array}{l}\mathrm{C} 2^{*} \text {. Cob. Verde com espessura de substrato inferior ou igual a } \\
40 \mathrm{~cm}\end{array}$ & medida do projeto & $\left(m^{2}\right)$ & 0,31 & cálculo conforme (IV) \\
\hline E. Pavimento poroso (10) & medida do projeto & $\left(\mathrm{m}^{2}\right)$ & 0,1 & cálculo conforme (IV) \\
\hline F. Pavimento semi-permeável sem vegetaçāo & medida do projeto & $\left(\mathrm{m}^{2}\right)$ & 0,78 & cálculo conforme (IV) \\
\hline G. Superficies com pavimentos não permeáveis (11) & medida do projeto & $\left(\mathrm{m}^{2}\right)$ & 0,82 & cálculo conforme (IV) \\
\hline \multicolumn{4}{|l|}{ D PARCIAL (12) } & cálculo conforme (V) \\
\hline $\begin{array}{l}\text { Volume de reservação minima obrigatório para controle de } \\
\text { escoamento superficial }\end{array}$ & medida do projeto & (l) & $\mathrm{n} / \mathrm{a}$ & $\mathrm{n} / \mathrm{a}$ \\
\hline $\begin{array}{l}\text { H. Volume de reservação proposto para controle de } \\
\text { escoamento superficial }\end{array}$ & medida do projeto & (l) & $\mathrm{n} / \mathrm{a}$ & $\mathrm{n} / \mathrm{a}$ \\
\hline \multicolumn{4}{|l|}{ D FINAL } & cálculo conforme (VII) \\
\hline \multicolumn{4}{|l|}{ ITEM IV. PONTUAÇÃO FINAL - QA } & cálculo conforme (VIII) \\
\hline
\end{tabular}

Figura 82 Quadro 3B Quota Ambiental. Disponível em: $<$ <ttp://gestaourbana.prefeitura.sp.gov.br/wpcontent/uploads/2015/12/QUADRO_3B_18_12_15.pdf> acesso em dezembro 2016. 
A Quota Ambiental não interfere nas exigências de instalação de reserva e controle de escoamento superficial (Art. 79 e 80), que devem ser obedecidas, "independentemente da adoção de outros mecanismos de controle do escoamento superficial que impliquem reservação e/ou infiltração e/ou percolação" (Art. 79).

Pode haver uma redução na taxa de permeabilidade, de acordo com:

- Lotes com área superior a $500 \mathrm{~m}^{2}$, que não estejam localizados em ZEPAM $^{41}$ ou ZPDS $^{42}$, podem ter a taxa de permeabilidade reduzida em até $50 \%$, desde que a pontuação da QA para o lote seja majorada na mesma proporção em que a taxa de permeabilidade seja reduzida (Art. $\left.81, \S 2^{\circ}\right)$;

- Lotes com área menor ou igual a $500 \mathrm{~m}^{2}$, isentos da aplicação da QA e que não estejam localizados em ZEPAM ou ZPDS, podem ter a taxa de permeabilidade reduzida em até $50 \%$, desde que seja atendida a pontuação mínima de QA igual a 0,15 (Art. 81, § 3º).

A redução da Quota Ambiental é concedida aos "casos de imóveis onde incide Termo de Compromisso Ambiental - TCA, firmado entre o órgão ambiental competente e pessoas físicas ou jurídicas, resultante de autorização prévia de manejo de espécies arbóreas, palmeiras e coqueiros", para os quais será aplicado "fator redutor de 0,50 ao Fator de eficácia ambiental do indicador cobertura vegetal - FV" (Art. 77).

A legislação da Quota Ambiental prevê a possibilidade de um incentivo se sob a forma de "desconto no valor total a ser pago na contrapartida financeira de outorga onerosa do direito de construir e limitado a este, já contabilizados os incentivos previstos na Lei n 16.050, de 31 de julho de 2014" (Art. 82).

Nos terrenos com área menor ou igual a $5.000 \mathrm{~m}^{2}$, quando o empreendimento atingir de 2 a 4 vezes a quota ambiental mínima, o empreendedor poderá optar por receber benefício em área não

${ }^{41}$ Zonas Especiais de Proteção Ambiental;

42 Zona de Proteção e Desenvolvimento Sustentável; 
Nas ZEU ${ }^{43}$, ZEUa, ZEUP ${ }^{44}$, ZEUPa, ZEM ${ }^{45}$ e ZEMP ${ }^{46}$, quando o interessado utilizar taxa de ocupação maior ou igual a 50\% da área do terreno, com no mínimo 20\% de cobertura verde, com fachada ativa no térreo e gabarito de altura máxima de $28 \mathrm{~m}$, o desconto concedido em outorga ou a área não computável concedida será equivalente ao dobro da pontuação obtida no projeto, até o limite máximo de incentivo (Art. $83, \S 4^{\circ}$ ).

A concessão de Incentivo de Certificação se dá sob a forma de desconto na contrapartida financeira de outorga onerosa do direito de construir, para novas edificações ou reformas com aumento de área construída superior a 5\% (cinco por cento) que obtiverem certificação específica de sustentabilidade reconhecida em âmbito nacional ou internacional (Art. 83).

O Incentivo de Certificação somente será concedido para edificações de uso residencial associadas ou não a usos não residenciais, e para os usos industriais (Art. 83, $\S 4^{\circ}$ ). Para empreendimentos em lotes com área superior a $2.500 \mathrm{~m}^{2} \mathrm{e}$ localizados nas ZEU, ZEUa, ZEUP e ZEUPa, o Incentivo de Certificação deverá estar associado à aplicação da Fachada Ativa em $20 \%$ da testada do lote (Art. 83, § 8º). Os empreendimentos que aderirem ao Incentivo de Certificação não estão dispensados do atendimento da pontuação mínima da QA (Art. 83, § 9º) e ele não é cumulativo ao Incentivo da Quota Ambiental (Art. 83, § 10%).

Por fim, a lei determina que deverão apresentar relatório a cada dois anos demonstrando atendimento a tais exigências, de acordo com o projeto aprovado as edificações obrigadas ao atendimento da QA (Art. 84) e os imóveis que tenham sido beneficiados pelo Incentivo de Quota Ambiental ou pelo Incentivo de Certificação (Art. 84, $\S 1^{\circ}$ ).

A principal fundamentação da QA é o reconhecimento da necessidade de qualificação dos espaços livres internos aos lotes por se tratarem de parcela considerável na contribuição com a melhoria da qualidade ambiental da cidade.

\footnotetext{
43 Zonas Eixo de Estruturação da Transformação Urbana;

44 Zonas Eixo de Estruturação da Transformação Urbana Previsto;

45 Zona Eixo de Estruturação da Transformação Metropolitana;

46 Zona de Estruturação da Transformação Metropolitana Prevista.
} 
Para os técnicos, o instrumento representa um complemento aos investimentos do poder público na melhoria das condições ambientais da cidade.

\section{Considerações sobre as políticas de planejamento ambiental}

No primeiro semestre de $2016^{47}$ foi iniciada uma análise comparativa entre as políticas públicas de compensação ambiental adotadas nas cidades de Berlim, Malmö, Seattle e a Quota Ambiental de São Paulo ${ }^{48}$. O referido trabalho buscou realizar uma análise comparativa dos parâmetros de projeto exigidos nos diferentes instrumentos que incentivam o uso da vegetação para melhoria da gestão das águas pluviais, fenômenos de aquecimento urbano e biodiversidade no espaço das cidades, tomando como referência a Quota Ambiental do Município de São Paulo.

\section{Considerações:}

GREEN SPACE FACTOR (MALMÖ):

1. Diferencia e valoriza diferentes tipos de espécies vegetais;

2. Não diferencia os tipos de parede vegetada, no entanto, considera apenas aquelas próximas ao pedestre, até uma altura de 10m;

3. Elementos com água também são considerados e muito valorizados na pontuação.

\section{SEATTLE GREEN FACTOR (SEATTLE):}

1. Apesar de similar à $Q A$, o sistema de bioretenção (uso de áreas naturais vegetadas sobre solo) SGF não é equivalente ao reservatório de retenção de águas pluviais da QA;

\footnotetext{
${ }^{47}$ Trabalho final desenvolvido juntamente com os alunos Henrique Benites e Mayumi Hirye para a disciplina AUT5823 - Conforto Ambiental em Espaços Urbanos Abertos, ministrada pelos professores Denise Duarte e Leonardo Monteiro.

${ }^{48} \mathrm{O}$ Apêndice 2 apresenta detalhes das inciativas internacionais aqui consideradas.
} 
2. Atende às mesmas condições da $Q A$, quando apresenta apenas o solo permeável e a vegetação arbórea; não atende o índice mínimo, porém atende o índice quando inserido o telhado verde, mesmo com a supressão das árvores de maneira similar ao verificado na QA;

3. Aplicável a qualquer novo empreendimento com mais de quatro unidades habitacionais ou terrenos a partir de $370 \mathrm{~m}^{2}$ de uso não residencial;

4. O sistema de bônus (0,1 a 0,2 por item), que não foi considerado, valoriza o uso de espécies nativas ou tolerantes à seca, água não potável para irrigação, que o paisagismo esteja visível para a cidade e o cultivo de alimentos.

Comparando-se os diferentes instrumentos, verifica-se que apenas a QA e o GSF consideram a quantidade de vegetação arbórea e seu porte no cálculo, apesar do baixo peso que os indivíduos assumem nos cálculos. Ainda assim, nenhum deles referência, diretamente, um indicador como o "índice de área foliar" (IAF) nos cálculos, tal como acontece com o Green Plot Ratio, de Singapura.

A discussão colocada por Gonçalves et al. (2016) para a QA se aplica a todos os instrumentos, pois as relações lote-calçada e entre lotes não são contemplados instrumentos analisados. No caso de São Paulo, não são aplicadas em nenhuma lei urbana, nem no Plano Diretor Estratégico (PDE), nem na Lei de Parcelamento, Uso e Ocupação do Solo (LPUOS). Adicionalmente, Gonçalves salienta que a QA reconhece apenas as ações e estratégias dos novos empreendimentos em lotes iguais ou maiores a $500 \mathrm{~m}^{2}$, ignorando a cidade já consolidada com lotes de pequeno porte que representam entre $70 \%$ e $80 \%$ do território urbano construído hoje, e a região da Operação Urbana Centro. 